FERNANDO ARTURO ERAZO LOZANO

\title{
SELEÇÃO DE LOCAIS PARA BARRAGENS DE REJEITOS USANDO O MÉTODO DE ANÁLISE HIERÁRQUICA.
}

Dissertação apresentada à Escola Politécnica da Universidade de São Paulo para a obtenção do título de Mestre em Engenharia

São Paulo 


\section{SELEÇÃO DE LOCAIS PARA BARRAGENS DE REJEITOS USANDO O MÉTODO DE ANÁLISE HIERÁRQUICA.}

Dissertação apresentada à Escola Politécnica da Universidade de São Paulo para a obtenção do título de Mestre em Engenharia.

Área de Concentração: Engenharia Geotécnica

Orientadora: Profa. Dra. Maria Eugenia Gimenez Boscov

São Paulo 
AUTORIZO A REPRODUÇÃO E DIVULGAÇÃO TOTAL OU PARCIAL DESTE TRABALHO, POR QUALQUER MEIO CONVENCIONAL OU ELETRÔNICO, PARA FINS DE ESTUDO E PESQUISA, DESDE QUE CITADA A FONTE.

FICHA CATALOGRÁFICA

\section{Erazo Lozano, Fernando Arturo}

Seleção de locais para barragens de rejeitos usando o método de análise hierárquica / Fernando Arturo Erazo Lozano. - São Paulo, 2006.

$128 \mathrm{p}$.

Dissertação (Mestrado) - Escola Politécnica da Universidade de São Paulo. Departamento de Engenharia de Estruturas e Fundações.

1. Barragens de rejeitos 2. Tomada de decisão 3. Impactos ambientais I. Universidade de São Paulo. Escola Politécnica. Departamento de Engenharia de Estruturas e Fundações II. t. 


\section{Dedicatória}

A Claudia, apoyo incondicional, amor y fortaleza en todo momento.

A nuestro futuro, semilla que se formó y esta nasciendo, creciendo.

A mis Padres con todo amor.

A toda mi familia.

Todo lo que he logrado hasta hoy es fruto de su dedicación y a ellos pertenece. 


\section{AGRADECIMENTOS}

À Profa. Dra. Maria Eugenia Gimenez Boscov, pelo apoio neste meu retorno acadêmico, seus comentários motivadores e empenho em sua orientação.

Ao Prof. Dr. Celso Santos Carvalho, pelas sugestões precisas no exame de qualificação e pela participação no final da pesquisa.

Ao Prof. Dr. Cláudio Barbieri da Cunha, pelos esclarecimentos no exame de qualificação.

À Companhia MINER S.A., aos engenheiros e geólogos, à parte técnica e aos trabalhadores, particularmente ao Dr. Guillermo Gaviria e ao Engenheiro Gabriel Ramirez Medina, pelo apoio fundamental na realização deste trabalho.

Aos Engenheiros Franklin Ortiz e Arturo Calle, pelo apoio na pesquisa ambiental.

À comunidade do Carmen de Atrato.

Aos meus amigos com quem tive o prazer de ter convivido: Alejandro, Martha, Arianna, Mauricio, Maria, Sol, Katherin, Lênin, e Magda, pela troca de apoio e força. Felicidade e sucesso para eles.

Aos meus colegas da sala 25 (Carlos, Marcio, Rafael, Alexei, Jorge, Raul, Arturo, Marcos), pela ajuda e colaboração em todos os momentos e por criar um ambiente agradável ao longo desses anos.

Ao pessoal da Biblioteca EPEC. À Sarah Ferreira, pela ajuda na revisão das referencias.

Novamente aos meus pais, Eduardo e Socorro, e meus irmãos, que de longe foram motivadores do meu trabalho. À minha grande família de Medellín, pela compreensão, apoio e constante incentivo. A Don Oscar, por deixar força em nossos corações.

À Claudia, mais uma vez, motivo dos meus esforços e luta.

À CAPES, pelo suporte financeiro ao final da pesquisa. 


\section{RESUMO}

Barragens de rejeitos são estruturas que têm a finalidade de reter os resíduos sólidos e água dos processos de beneficiamento de minério. Seu planejamento inicia com a procura do local para implantação, etapa na qual se deve vincular todo tipo de variáveis que direta ou indiretamente influenciam a obra: características geológicas, hidrológicas, topográficas, geotécnicas, ambientais, sociais, avaliação de riscos, entre outras. Este trabalho apresenta um estudo sobre a utilização do método de analise hierárquica como apoio na tomada de decisões para seleção de locais para barragens de rejeitos. A revisão bibliográfica de fatores que influem nesta etapa de decisão resultou em indicadores claros de avaliação, que foram orientadores para a coleta de dados no estudo de caso. O estudo de caso consistiu na avaliação de três locais para a localização da nova barragem de rejeitos de beneficiamento de cobre a ser construída pela MINER S.A. no município de Carmen de Atrato, na Colômbia. Para a seleção do local entre três alternativas, foram considerados dois aspectos: custo inicial total e impacto ambiental. Na aplicação do método de análise hierárquica, o objetivo principal da hierarquia proposta foi o menor impacto ambiental, considerando-se as três causas consideradas mais importantes: implantação da barragem, ruptura da barragem e transporte de rejeitos da usina ao local de disposição. Foram analisados os impactos potenciais na água, solo, fauna, flora e ocupação humana. Os custos foram tratados separadamente. No final foi realizada uma análise conjunta dos custos iniciais totais e dos resultados do método de análise hierárquica, para servir como apoio ao tomador de decisão. Foi também realizada uma análise de sensibilidade, que mostra a influência significativa de um dos critérios nos pesos finais dos locais avaliados.

Palavras chave: Barragem de rejeitos. Decisão. Impacto ambiental. 


\begin{abstract}
Tailings dams are structures designed to retain solid wastes and water generated in the processing of metal ore. The overall planning of these dams starts with site selection, step in which all directly or indirectly influential variables should be considered: geological, hydrological, topographic, geotechnical, environmental and social characteristics, risk evaluation etc. This work presents a study of the utilization of the hierarchy analysis process (AHP) as a tool for decision-making in the selection of sites for tailings dams. The bibliographic review of relevant factors resulted in the proposal of a list of indicators, which was very useful as an orientation for data collection in the study case, and is considered as an important contribution from this research. The study case consisted in the location of the new copper tailings dam of MINER Inc. in Carmen de Atrato, Colombia. Initially, a geochemical software was applied to the region to discard unsuitable areas. For the selection of a site among three resulting alternatives, two aspects were taken into account: total initial cost and environmental impact. In the application of AHP, the main objective of the proposed hierarchy was the lowest environmental impact. Three possible causes were considered as the most important concerning environmental impact: dam and reservoir occupancy, dam collapse and transportation of wastes from the plant to the disposal site. Potential impacts on water, soil, fauna, flora and human occupation were analyzed. Costs were treated separately. Finally, a joint analysis of total initial costs and results from the AHP application was carried out in order to convey a support for the decision maker. A sensilibtily analysis was also performed to show the influence of one of the subcriteria on the final alternatives weights.
\end{abstract}

Key-words: Tailing dams. Decision. Environmental impact. 


\section{SUMARIO}

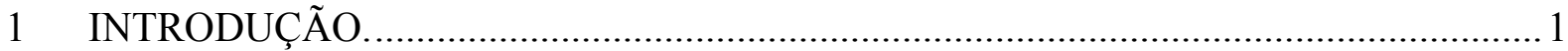

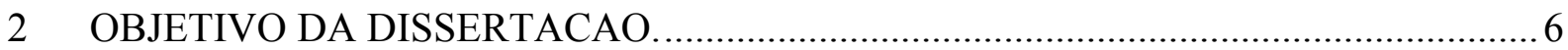

3 DISPOSIÇÃO DE REJEITOS DE MINERAÇÃO .......................................................

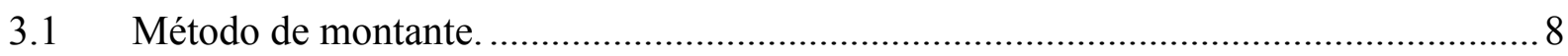

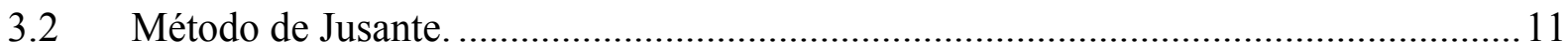

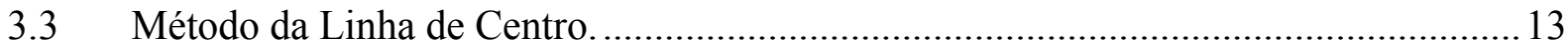

3.4 Deposição subterrânea (disposição em cavas de mineração)....................................... 16

3.5 Deposição em "pit" (Processos de extração de minério a céu aberto). ......................... 18

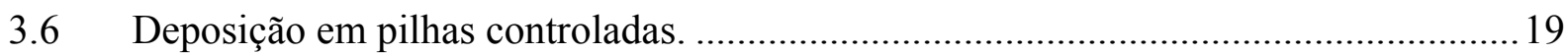

4 FATORES QUE INFLUENCIAM A ESCOLHA DO LOCAL DE IMPLANTAÇÃO DE BARRAGENS DE CONTENÇÃO DE REJEITOS.................................................... 21

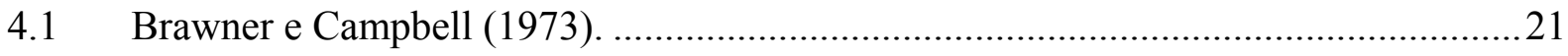

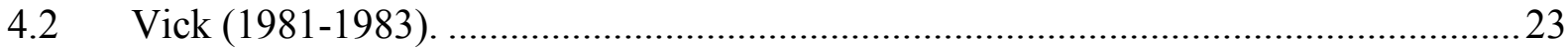

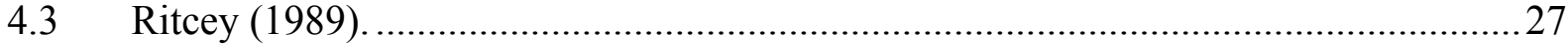

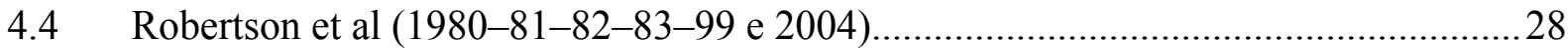

4.5 Zuquette e Gandolfi (2004), Liporaci e Zuquette (1995)........................................... 37

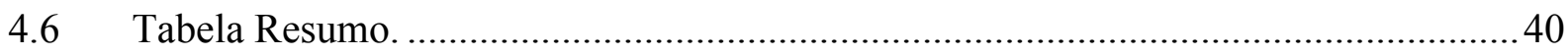

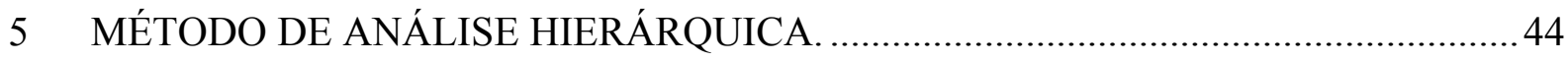

5.1 Métodos multicriteriais de auxílio à tomada de decisões........................................... 44

5.2 Conceituação do Método de Análise Hierárquica (Analytic Hierarchy Process - AHP).

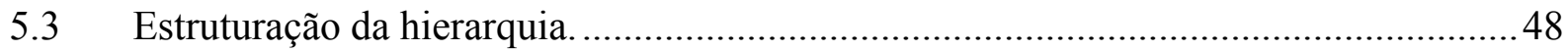

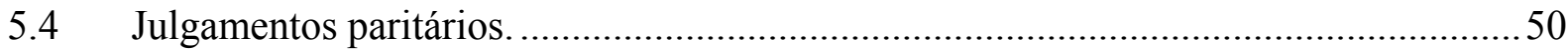

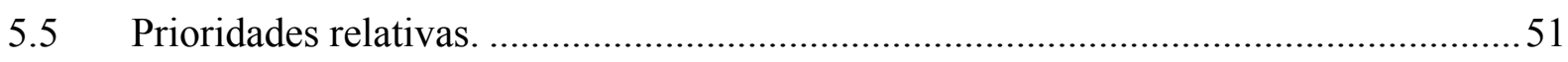

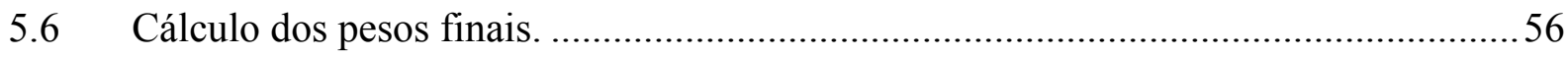

5.7 Variante multiplicativa do método de análise hierárquica. ........................................57

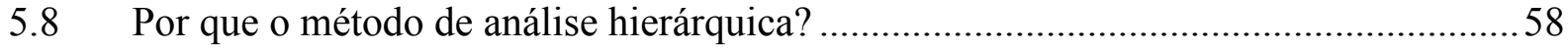

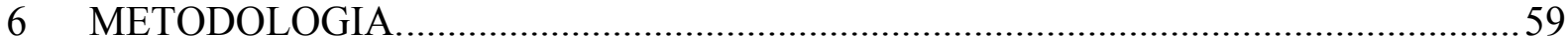

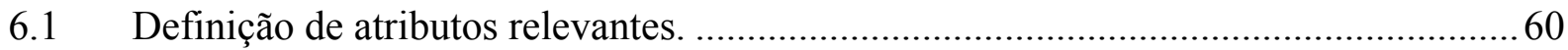

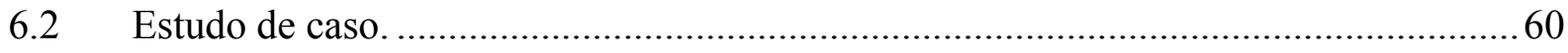




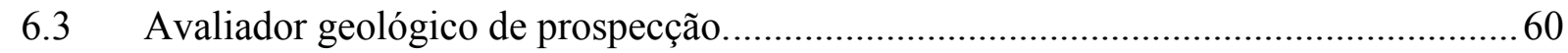

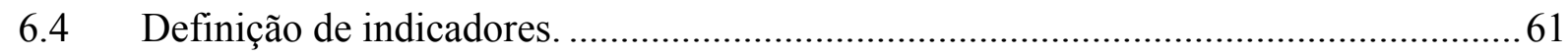

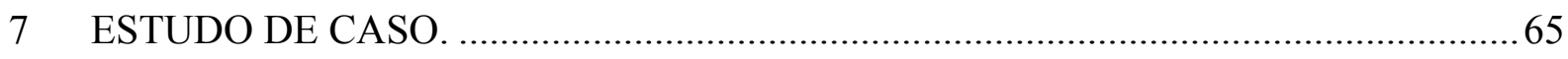

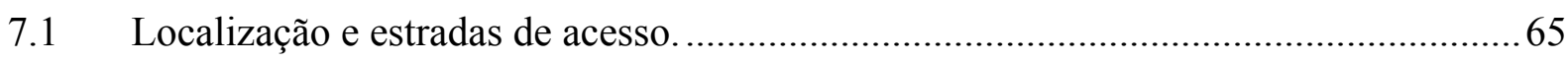

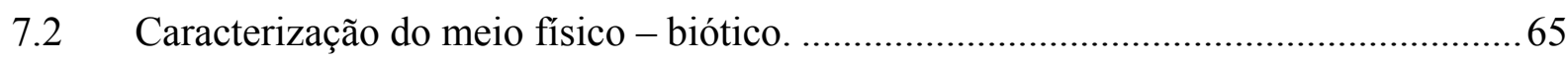

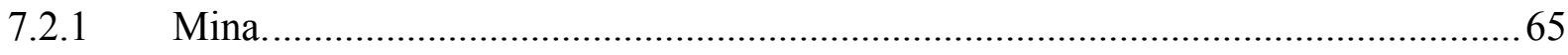

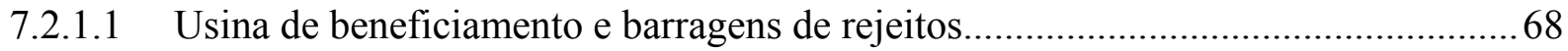

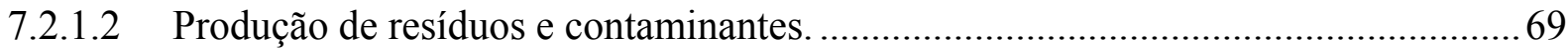

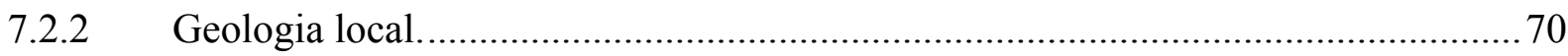

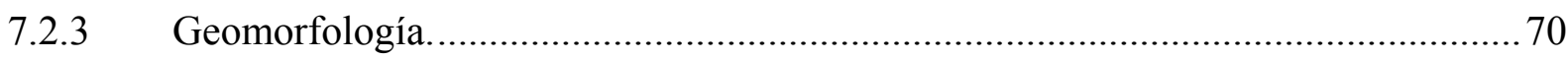

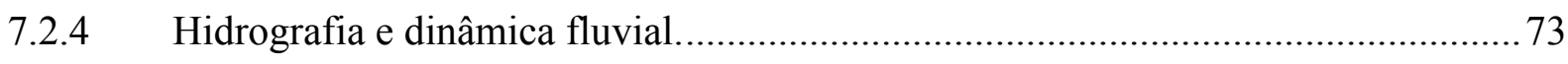

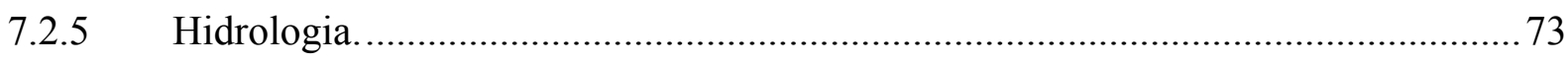

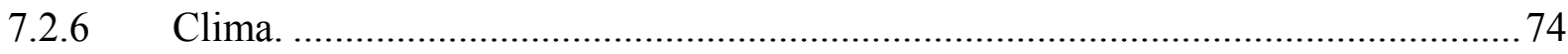

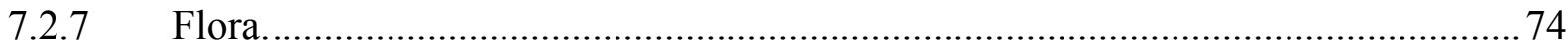

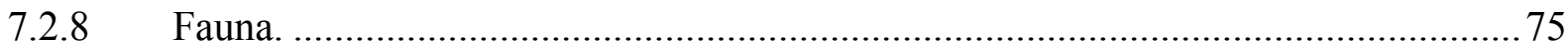

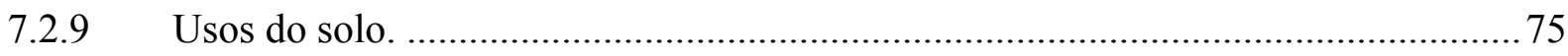

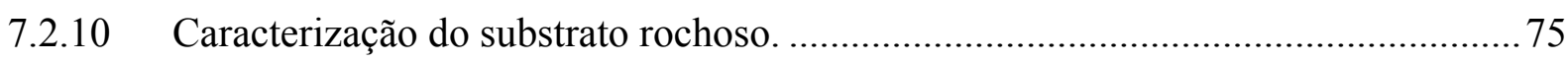

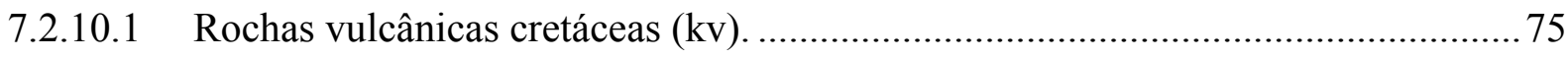

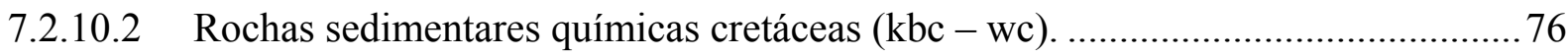

7.2.10.3 Rochas sedimentares clásticas cretáceas (kss) ................................................... 76

7.2.10.4 Depósitos quaternários (coluvião (qc) - aluvião (qal)) …….............................. 76

7.3 Avaliador geológico de prospecção............................................................................. 79

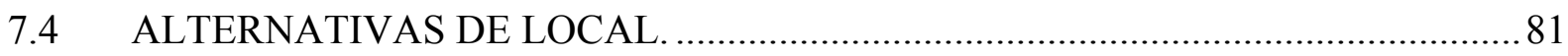

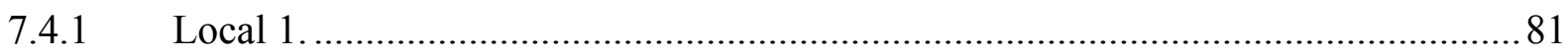

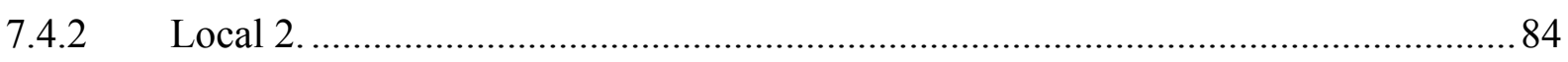

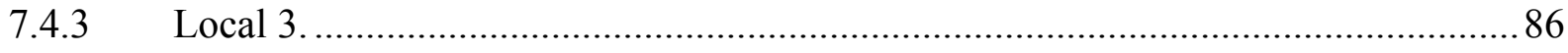

8 APLICAÇÃO DO MÉTODO DE ANÁLISE HIERÁRQUICA NO ESTUDO DE CASO

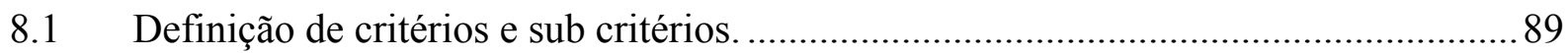

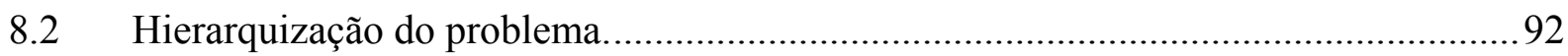

8.3 Julgamentos paritários, prioridades relativas e consistência...................................... 92

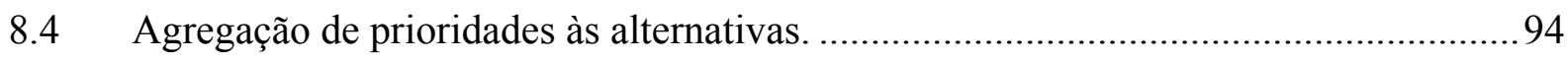

8.5 Aplicação da variante multiplicativa do método de análise hierárquica. .....................96

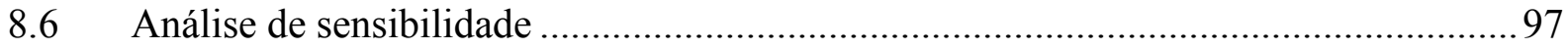




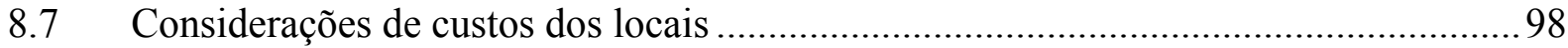

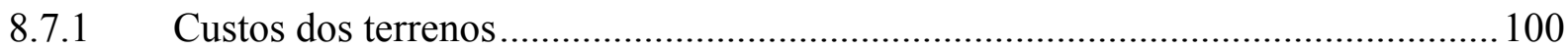

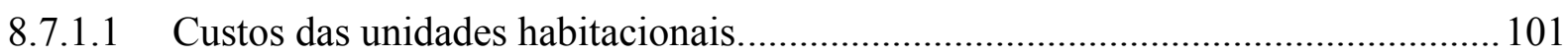

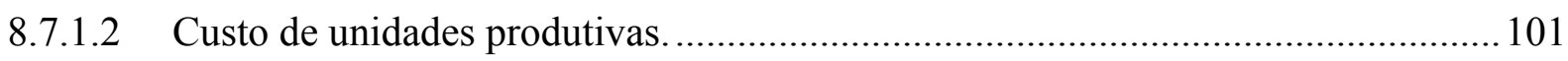

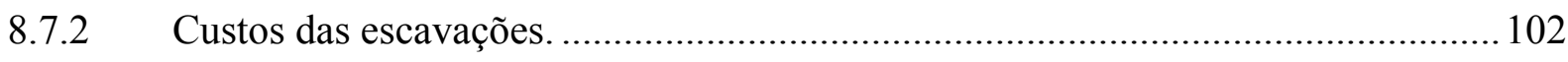

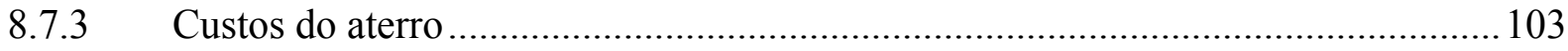

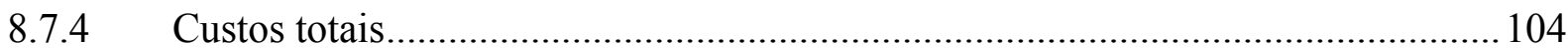

8.8 Análise conjunta de custos totais e pesos resultantes da análise hierárquica. ............ 104

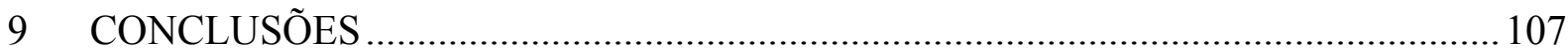

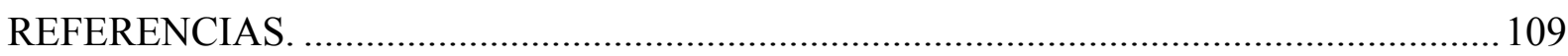

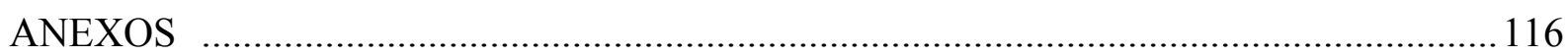




\section{LISTA DE ILUSTRAÇÕES}

Figura 1. Evolução no tempo das atividades relativas a barragens de rejeitos (La Asociación Minera de Canadá 1998). 3

Figura 2. Custos para minimizar o risco de acidentes vs custos de acidentes (Mello 1981)......4

Figura 3. Método de montante (Vick 1981, modificado). 9

Figura 4. Desvantagens do método de montante: (a) linha freática elevada; (b) superfície provável de ruptura passa pelos rejeitos; (c) risco de ruptura por "piping” (Silveira e

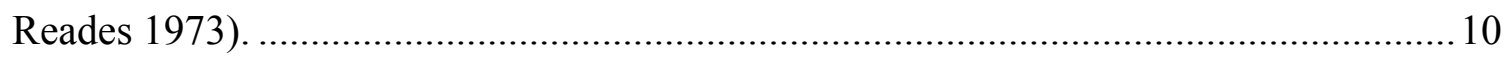

Figura 5. Método de jusante (Vick 1981, modificado)......................................................... 11

Figura 6. Método de jusante com enrocamento (Nieble 1976, modificado)........................... 12

Figura 7. Método da linha de centro (Nieble 1976, modificado).......................................... 13

Figura 8. Comparação de volumes para vários tipos de barragem: (a) Método de montante. (b)

Método de jusante. (c) Método da linha do centro (Vick 1983, modificado). ................. 16

Figura 9. Deposição em "pit”: (a) Extração do minério total. (b) Deposição feita ao mesmo tempo do que a extração do mineiro ( Ritcey 1989, modificado). ................................... 18

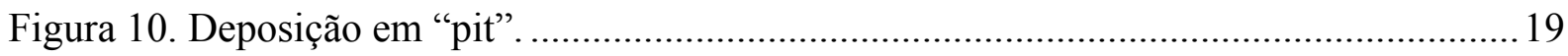

Figura 11. Programa de planejamento e projeto de uma barragem de rejeitos (Brawner e

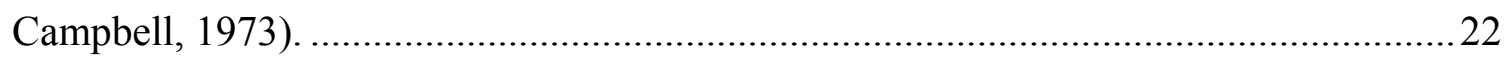

Figura 12. Represamento em anel: (a) simples. (b) múltiplos (Vick 1983). .......................... 24

Figura 13. Represamento em anel: vista aérea (ICME-UNEP 1998)....................................24

Figura 14. Represamento em bacia: (a) simples. (b) múltiplos (Vick 1983)..........................25

Figura 15. Represamento em bacia: mineração de ouro, Rio Paracatu Mineração, Minas

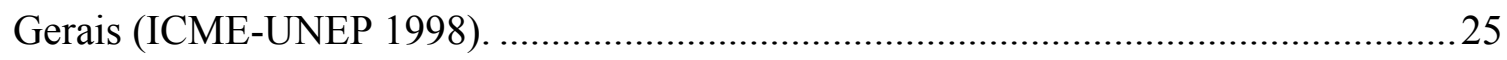

Figura 16. Represamento a meia encosta: (a) simples. (b) múltiplos (Vick 1983).................26

Figura 17. Represamento em vale: (a) simples. (b) múltiplos (Vick 1983). ..........................27

Figura 18. Represamento em vale: mineração de cobre, MINER S.A., Colômbia.................. 27

Figura 19. Aspectos técnicos que relacionam a barragem de rejeito e o meio ambiente.

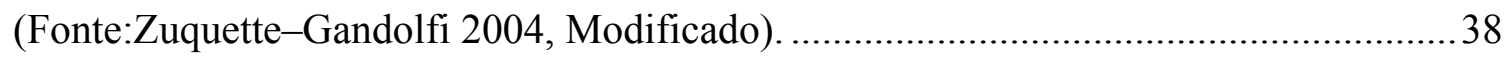

Figura 20. Modelo de hierarquização para avaliação de alternativas (Morita 1998). .............. 49

Figura 21. Localização geográfica do Município de Carmen de Atrato. ................................66

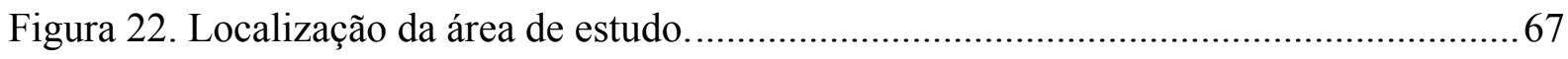




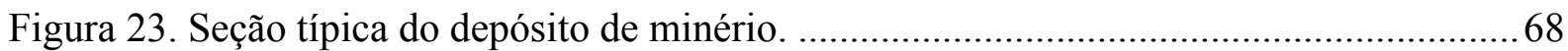

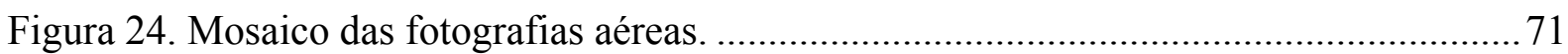

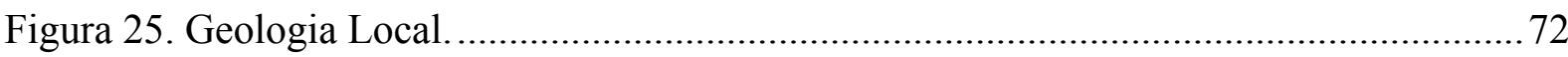

Figura 26. Maciço rochoso com escarpa de falha, que situa o contato de rocha sedimentar clástica (Kss) com chert negro (Kbc). No declive há acumulação de coluvião (Qc) de grandes blocos 77

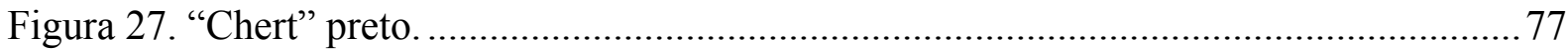

Figura 28. Vista panorâmica do lado norte da área de estudo, apresentando as estruturas rochosas. 78

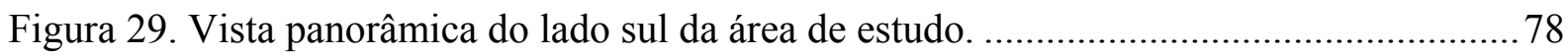

Figura 30. Geoquímica da zona de estudo: (a) Ouro, (b) Prata, (c) Chumbo, (d) Zinco.......... 80

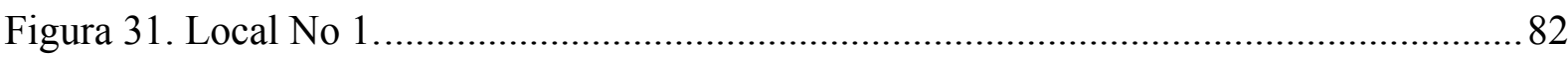

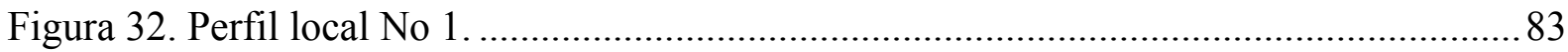

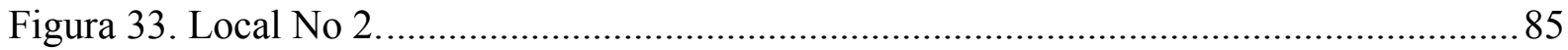

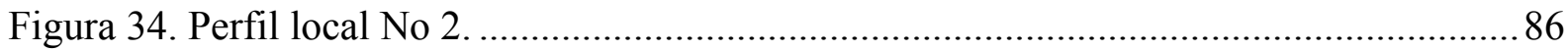

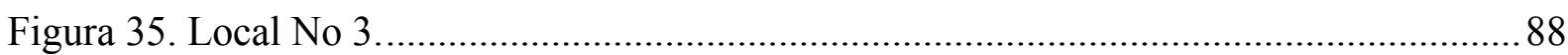

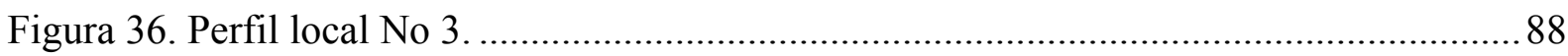

Figura 37. Hierarquia de ajuda na decisão de seleção de locais no estudo de caso. ................ 92

Figura 38. Alteracion Julgamento Água - Ocupação Humana. ............................................... 98

Figura 39. Representação das variáveis coeficiente de aspecto econômico e peso do local

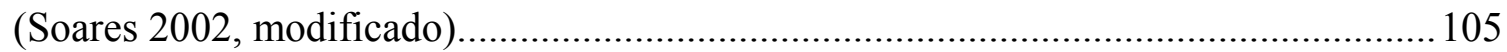

Figura 40. Análise conjunta de custos totais e pesos resultantes.......................................... 106 


\section{LISTA DE TABELAS}

Tabela 1. Principais impactos ambientais da mineração no Brasil (Gomes Faria, 2002). .........2

Tabela 2. Comparação entre as características das barragens de rejeitos (Vick 1983,

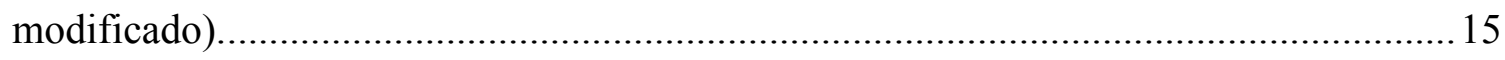

Tabela 3. Vantagens e desvantagens dos três tipos de barragens de rejeitos (Soares 2004,

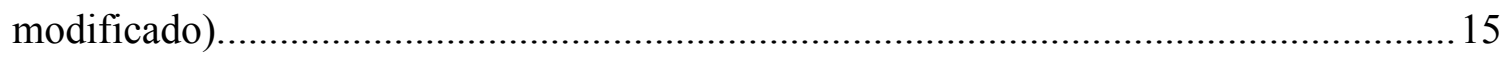

Tabela 4. Seções transversais típicas de aterros hidráulicos (Espósito 2000, modificado)...... 17

Tabela 5. Fatores que influenciam a escolha do local para barragem de rejeitos (Vick 1981-

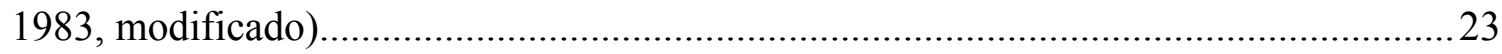

Tabela 6. Critérios para a escolha do local para implantação de uma barragem de rejeitos

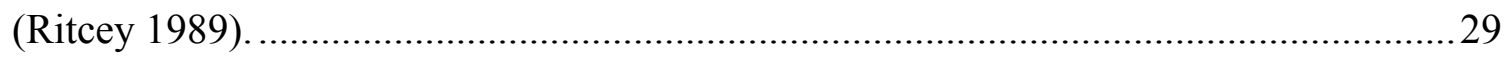

Tabela 7. Critérios para excluir áreas na investigação regional. .......................................... 31

Tabela 8. Critérios de investigação para identificar características desfavoráveis do local..... 32

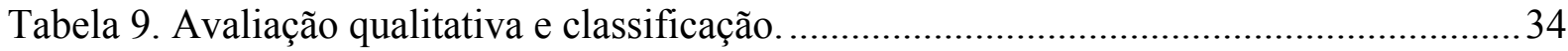

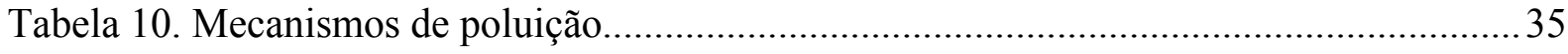

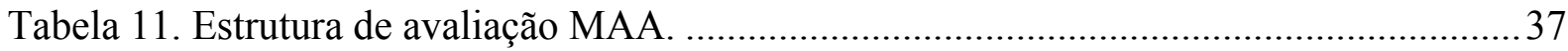

Tabela 12. Atributos para definição e delimitação de unidades do meio físico visando à

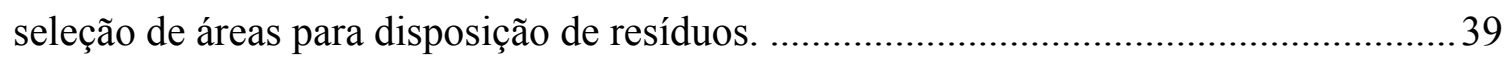

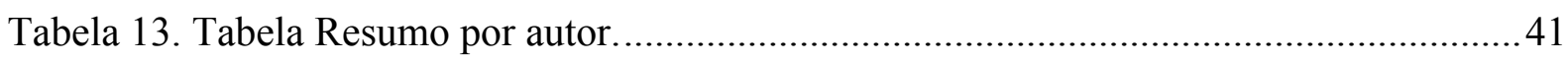

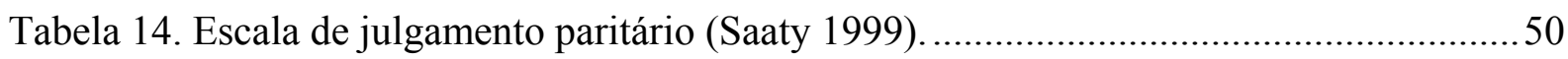

Tabela 15. Índice randômico em função da ordem da matriz de comparações paritárias (Saaty

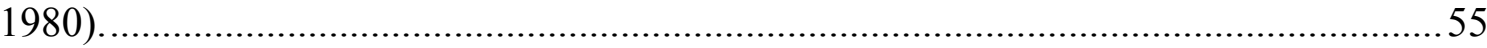

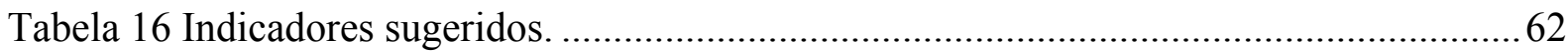

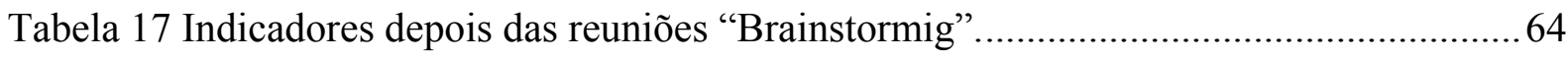

Tabela 18. Características das drenagens da mina e dos efluentes das barragens de rejeitos..69

Tabela 19. Comportamento da vazão do Rio Atrato no ponto "Puente Sanchez". .................. 74

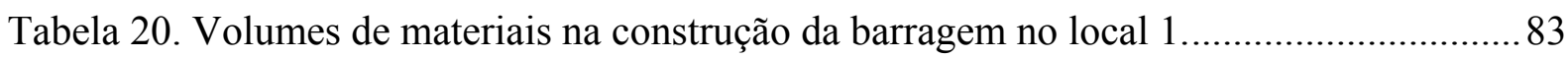

Tabela 21. Volumes de materiais na construção da barragem no local 2 ................................ 86

Tabela 22. Volumes de materiais na construção da barragem no local 3................................ 88

Tabela 23. Relação de critérios e sub-critérios com indicadores propostos. ............................90

Tabela 24 Critérios e sub-critérios que vão ser avaliados para o estudo de caso. ...................91 


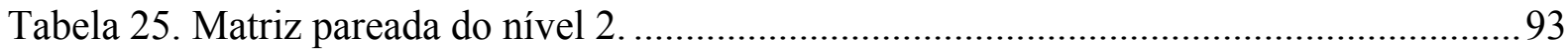

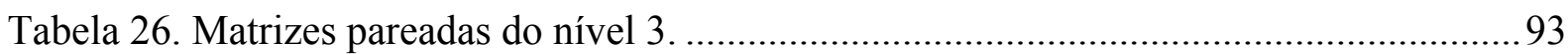

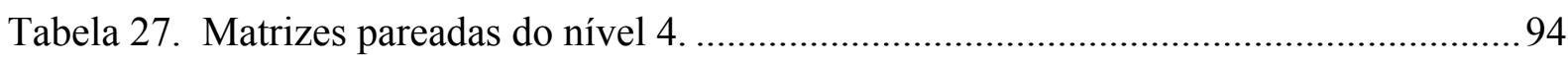

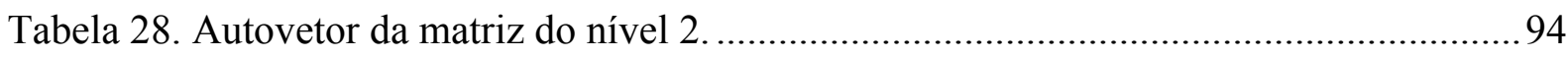

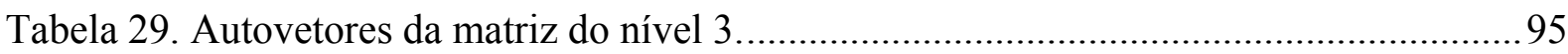

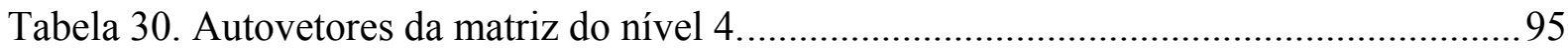

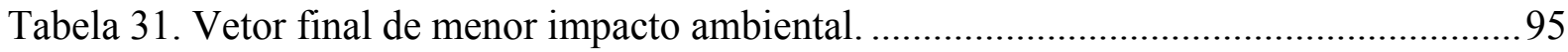

Tabela 32. Critérios e alternativas na variante multiplicativa do método AHP. .....................96

Tabela 33. Áreas, volumes, movimentos de terra e escavações nos diferentes locais. .......... 100

Tabela 34. Características médias das propriedades rurais com igual valor potencial do solo

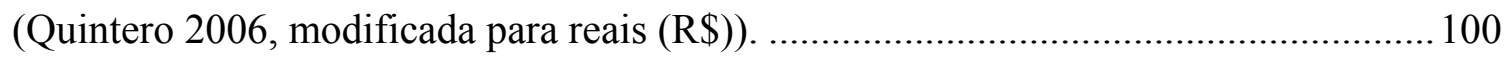

Tabela 35. Inversão de capital em terras, infraestrutura e equipamentos. (Holmann 2003 -

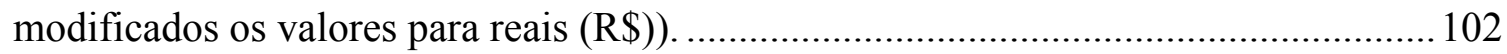

Tabela 36. Custo total dos terrenos (valores em reais (R\$), 2006)..................................... 102

Tabela 37. Custos de escavação (convertidos em reais (R\$)). ............................................. 103

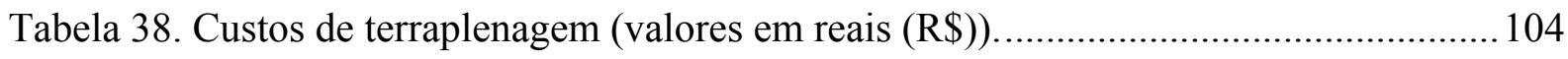

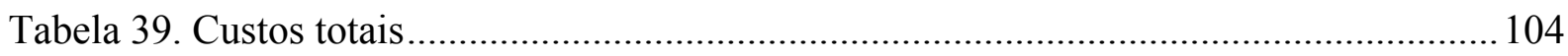

Tabela 40. Coeficientes de aspecto econômico................................................................. 105 


\section{INTRODUÇÃO.}

Um dos atores que potencialmente geram maior impacto no meio ambiente são as atividades de mineração. Nos países onde há falta de controle ambiental, a mineração gera conflitos sócio-ambientais, devido à sua interferência nos ecossistemas e nas comunidades. É imprescindível desenvolver novas tecnologias e/ou aplicar metodologias já disponíveis que minimizem esses impactos. Empresas de mineração atualmente têm consciência da necessidade de investimentos adicionais relacionados ao controle ambiental desde o início do projeto até a mitigação ambiental.

Os resíduos sólidos são os principais responsáveis pelo impacto ambiental nas atividades mineradoras. Seu tratamento e armazenamento visando minimizar os custos e maximizar a segurança são um dos principais objetivos das mineradoras para cumprir as exigências ambientais, já que a disposição dos resíduos é catalogada como um custo adicional sem retorno dentro do projeto.

Existem dois tipos de resíduos produzidos pelas atividades mineradoras, os estéreis e os rejeitos. No decapeamento da jazida são produzidos materiais sem nenhum valor econômico, denominados estéreis; estes são dispostos, geralmente, em pilhas e utilizados algumas vezes no próprio sistema de extração do minério. Os rejeitos são resultantes do processo de beneficiamento do minério; contêm elevado grau de toxicidade, além de partículas dissolvidas e em suspensão, metais pesados e reagentes.

Nos processos de beneficiamento, a quantidade gerada de rejeitos é muito alta, e a disposição é feita, dependendo dos objetivos econômicos da mineradora, em superfície, ou vinculada no processo de extração do minério de forma subterrânea ou a céu aberto. Gomes Faria (2002) resume na Tabela 1 alguns dos impactos que geram as atividades mineradoras no Brasil.

Observa-se que as barragens de rejeitos, que são estruturas construídas com a finalidade de reter os rejeitos produzidos pelo processo de beneficiamento, representam uma fonte de poluição importante, portanto sua construção, desde a escolha da localização até o fechamento, deve seguir as normas ambientais e os critérios econômicos, geotécnicos, estruturais, sociais e de segurança e risco. 
Tabela 1. Principais impactos ambientais da mineração no Brasil (Gomes Faria, 2002).

\begin{tabular}{|c|c|c|c|}
\hline $\begin{array}{l}\text { Substância } \\
\text { Mineral }\end{array}$ & Estado & Principais problemas & Ações Preventivas e/ou Corretivas \\
\hline Ferro & MG & $\begin{array}{l}\text { Antigas barragens de contenção, } \\
\text { poluição de águas superficiais. }\end{array}$ & $\begin{array}{l}\text { Cadastramento das principais } \\
\text { barragens de decantação em } \\
\text { atividade e as abandonadas; } \\
\text { caracterização das barragens quanto } \\
\text { à estabilidade; preparação de estudos } \\
\text { para estabilização. }\end{array}$ \\
\hline \multirow{3}{*}{ Ouro } & PA & $\begin{array}{l}\text { Utilização de mercúrio na } \\
\text { concentração do ouro de forma } \\
\text { inadequada; aumento da turbidez, } \\
\text { principalmente na região de Tapajós. }\end{array}$ & $\begin{array}{l}\text { Divulgação de técnicas menos } \\
\text { impactantes; monitoramento de rios } \\
\text { onde houve maior uso de mercúrio. }\end{array}$ \\
\hline & MG & $\begin{array}{l}\text { Rejeitos ricos em arsênio; aumento da } \\
\text { turbidez. }\end{array}$ & $\begin{array}{l}\text { Mapeamento e contenção } \\
\text { rejeitos abandonados }\end{array}$ \\
\hline & MT & $\begin{array}{l}\text { Emissão de mercúrio na queima de } \\
\text { amálgama. }\end{array}$ & $\begin{array}{llll}\begin{array}{l}\text { Divulgação de } \\
\text { impactantes. }\end{array} & \text { técnicas } & \text { menos } \\
\end{array}$ \\
\hline $\begin{array}{l}\text { Chumbo, } \\
\text { Zinco e Prata. }\end{array}$ & SP & Rejeitos ricos em arsênio. & $\begin{array}{l}\text { Mapeamento e contenção dos } \\
\text { rejeitos abandonados. }\end{array}$ \\
\hline Chumbo & BA & Rejeitos ricos em arsênio. & $\begin{array}{l}\text { Mapeamento e contenção dos } \\
\text { rejeitos abandonados. }\end{array}$ \\
\hline Zinco & $\mathrm{RJ}$ & $\begin{array}{l}\text { Barragem de contenção de rejeitos de } \\
\text { antiga metalurgia, em péssimo estado } \\
\text { de conservação. }\end{array}$ & $\begin{array}{l}\text { Realização das obras sugeridas no } \\
\text { estudo contratado pelo Governo do } \\
\text { Estado do Rio de Janeiro. }\end{array}$ \\
\hline Carvão & $\mathrm{SC}$ & $\begin{array}{l}\text { Contaminação das águas superficiais } \\
\text { e subterrâneas pela drenagem ácida } \\
\text { proveniente de antigos depósitos de } \\
\text { rejeitos. }\end{array}$ & $\begin{array}{ll}\text { Atendimento às } & \text { sugestões contidas } \\
\text { no Projeto } & \text { Conceitual para } \\
\text { Recuperação da } & \text { Bacia Carbonífera } \\
\text { Sul Catarinense. } & \end{array}$ \\
\hline \multirow{3}{*}{$\begin{array}{l}\text { Agregados } \\
\text { para } \\
\text { construção } \\
\text { civil }\end{array}$} & RJ & $\begin{array}{l}\text { Produção de areia em } \\
\text { Itaguaí/Seropédica: contaminação do } \\
\text { lençol freático, uso futuro da terra } \\
\text { comprometido devido à criação } \\
\text { desordenada de áreas alagadas. }\end{array}$ & $\begin{array}{l}\text { Disciplinamento da atividade; } \\
\text { estudos de alternativas de } \\
\text { abastecimento. }\end{array}$ \\
\hline & SP & $\begin{array}{l}\text { Produção de areia no Vale do Paraíba } \\
\text { acarretando a destruição da mata } \\
\text { ciliar, turbidez, conflitos com uso e } \\
\text { ocupação do solo, acidentes nas } \\
\text { rodovias causados pelo transporte. }\end{array}$ & $\begin{array}{l}\text { Disciplinamento da atividade; } \\
\text { estudos de alternativas de } \\
\text { abastecimento e de transporte. }\end{array}$ \\
\hline & $\begin{array}{l}\text { RJ } \\
\text { SP }\end{array}$ & $\begin{array}{l}\text { Produção de brita nas Regiões } \\
\text { Metropolitanas do Rio de Janeiro e } \\
\text { São Paulo, acarretando: vibração, } \\
\text { ruído, emissão de particulado, } \\
\text { transporte, conflitos com uso e } \\
\text { ocupação do solo. }\end{array}$ & $\begin{array}{l}\text { Aplicação de técnicas menos } \\
\text { impactantes; estudos de alternativas } \\
\text { de abastecimento. }\end{array}$ \\
\hline Calcário & $\begin{array}{l}\text { MG e } \\
\text { SP }\end{array}$ & $\begin{array}{l}\text { Mineração em áreas de cavernas com } \\
\text { impactos no } \\
\text { espeleológico. }\end{array}$ & $\begin{array}{l}\text { Melhor disciplinamento da atividade } \\
\text { através da revisão da Resolução } \\
\text { Conama n } \mathrm{n}^{\mathrm{o}} 5 \text { de } 06 / 08 / 1987 \\
\text { (proteção patrimônio espeleológico). }\end{array}$ \\
\hline Gipsita & PE & $\begin{array}{l}\text { Desmatamento da região do Araripe } \\
\text { devido à utilização de lenha nos } \\
\text { fornos de queima da gipsita. }\end{array}$ & $\begin{array}{l}\text { Utilização de outros tipos de } \\
\text { combustível e incentivo ao } \\
\text { reflorestamento com espécies nativas }\end{array}$ \\
\hline Cassiterita & $\begin{array}{ll}\mathrm{RO} & \mathrm{e} \\
\mathrm{AM} & \\
\end{array}$ & $\begin{array}{l}\text { Destruição de florestas e leitos de } \\
\text { rios. }\end{array}$ & $\begin{array}{l}\text { Racionalização da atividade para } \\
\text { minimizar os impactos. }\end{array}$ \\
\hline
\end{tabular}


As etapas da vida útil de uma barragem de rejeitos compreendem a procura do local, o projeto da instalação, a construção, a operação e o fechamento definitivo (Figura 1). O processo de seleção de locais aptos divide-se em duas fases claramente diferenciadas. Na primeira fase realiza-se uma avaliação em grande escala, que tem como objetivo descartar áreas impróprias e obter uma classificação preliminar das zonas aceitáveis, baseada em fatores gerais. Podemse utilizar avaliadores geológicos de prospecção como a geoquímica ou a geofísica, para identificar áreas potencialmente exploráveis para extração de minério. Áreas com aspectos legais impeditivos também são eliminadas nesta fase, como por exemplo, áreas de proteção ambiental e de patrimônio histórico. Na segunda fase, uma vez delimitadas regiões alternativas menores, utilizam-se fatores mais específicos de escolha.

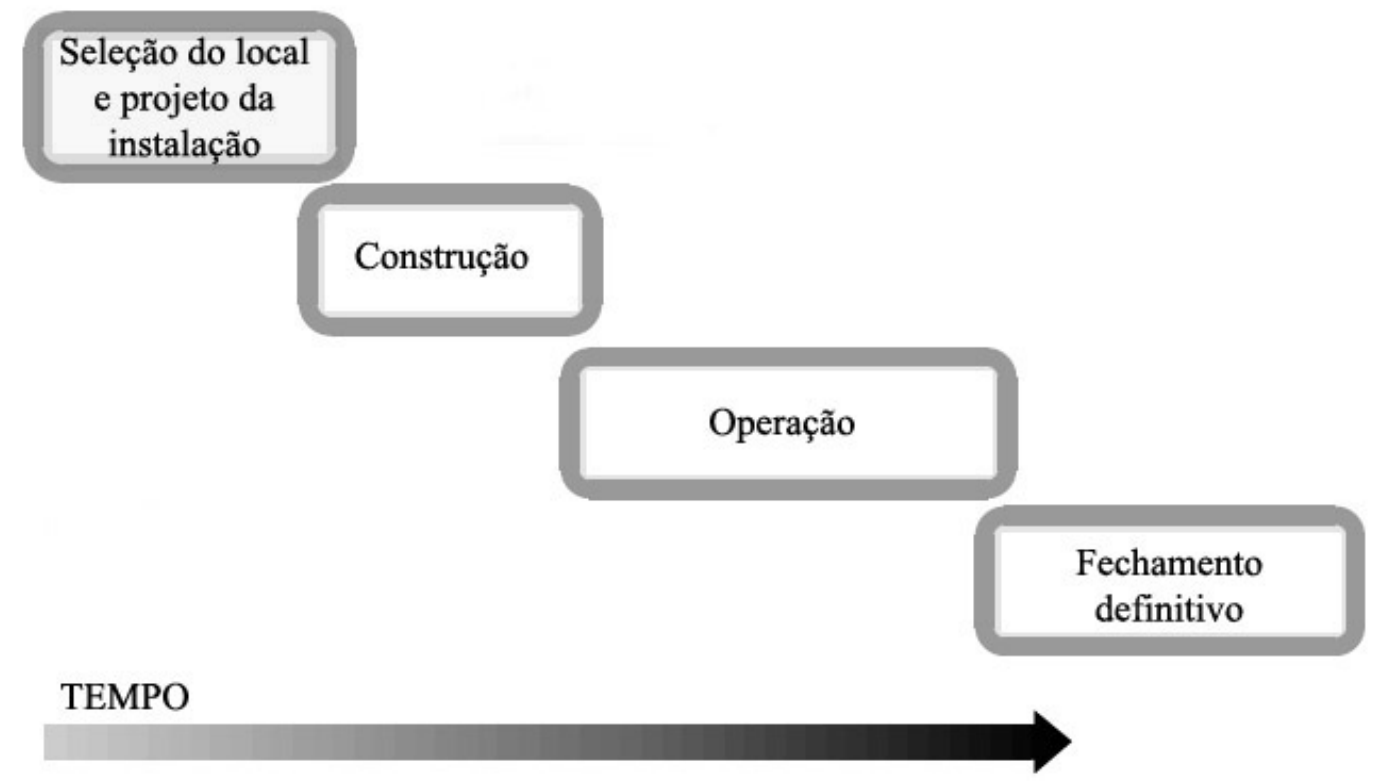

Figura 1. Evolução no tempo das atividades relativas a barragens de rejeitos (La Asociación Minera de Canadá 1998).

Para as empresas mineradoras as variáveis consideradas para determinar a melhor opção de local se limitam às econômicas, já que a disposição dos rejeitos é um investimento sem retorno a curto ou médio prazo. As novas legislações ambientais, porém, obrigam os mineradores a considerar também as variáveis ambientais, as estruturais, as geológicas e até os impactos que os rejeitos gerarão nas comunidades circunvizinhas.

É necessário na seleção de local vincular todo tipo de variáveis que direta ou indiretamente influenciam a obra: características geológicas, hidrológicas, topográficas, geotécnicas, ambientais, sociais, avaliação de riscos, entre outras. Segundo De Mello (1987), não se deve 
subestimar o que pode suceder na construção, operação ou fechamento de uma barragem de rejeitos, a lista de checagem deve ser ampla, considerando tudo ou tanto quanto se possa imaginar como admissível: "O importante é não começar os raciocínios às avessas, admitindo que quase nada possa ocorrer, até ser surpreendido com a ocorrência”. No estudo apresentado por Mello (1981) sobre segurança das barragens de rejeitos nos Estados Unidos (Figura 2), observa-se que os custos nos estudos preliminares são muito menores do que os custos de um eventual acidente, isto é, o investimento nas etapas iniciais do planejamento garante a segurança das estruturas e representa uma economia em longo prazo.

\begin{tabular}{|l|l|l|l|l|l|l|l|l|l|}
\hline \multicolumn{7}{|c|}{ CUSTOS PARA MINIMIZAR O RISCO DE ACIDENTES } \\
\hline ESTUDOS PRELIMINARES & & & & & & & & & \\
\hline
\end{tabular}

Figura 2. Custos para minimizar o risco de acidentes vs custos de acidentes (Mello 1981).

Contudo, a tomada de decisões na localização da barragem de rejeitos geralmente não utiliza métodos apropriados, que estabeleçam claramente as variáveis envolvidas e que associem um peso ou um valor obtido com consistência matemática a cada alternativa.

Segundo Galves (1995), a partir do início dos anos 60 houve uma crescente conscientização quanto à necessidade de se considerarem vários objetivos na análise e solução dos problemas relacionados a obras de grande porte. O enfoque tradicional, baseado na estimativa de benefícios e custos, deu lugar a uma abordagem mais realista, que inclui objetivos ambientais e sociais, com o subseqüente desenvolvimento de diversos métodos de auxílio à decisão, capazes de tratar problemas com objetivos múltiplos de uma maneira formal. 
A aplicação de um método de análise formal e rigoroso matematicamente pode contribuir para a definição objetiva do problema, a possibilidade de comunicação do problema em uma linguagem universal, a contribuição na tomada de decisões coletivas e a possibilidade de realizar análises de sensibilidade, além de indicar os aspectos a serem aperfeiçoados na continuidade do processo de planejamento.

Um dos métodos que tem aceitação nos processos de análise multicriterial é o método de análise hierárquica ou AHP (Analytic Hierarchy Process), que tem sido utilizado desde sua criação por Thomas Saaty em 1977 em múltiplos problemas de natureza quantitativa e qualitativa. Em nível mundial tem-se conhecimento da aplicação deste método em problemas econômicos/gerenciais (finanças, previsão macroeconômica, estratégia, planejamento, alocação de recursos, transporte, recursos hídricos), políticos (controle de armas nucleares, conflitos e negociação, influência mundial), sociais (educação, meio ambiente, saúde, jurídico, medicamentos) e tecnológicos (seleção de mercados, transferência tecnológica).

Este método também tem sido utilizado em pesquisas de mestrado e doutorado da Universidade de São Paulo, nas áreas da engenharia de produção (Carvalho 1997, Morita 1998, Moares 2003, Enoki 2006), transportes (Figueredo 1999, Iañez 2002, Lisboa 2002, Gimenes 2002, Gonçalves 2005), naval e oceânica (Garber 2002), civil (Silva 2003), recursos hídricos (Zuffo 1998), geociências (Nunes 2002) e mapeamento geotécnico (Marques 2002).

O método de análise hierárquica é de fácil aplicação do ponto de vista matemático; por outro lado, a utilização adequada requer um conhecimento profundo do problema e do próprio método, o que justifica o número de pesquisas citadas em diferentes áreas do conhecimento. Neste trabalho é desenvolvida a aplicação do método de análise hierárquica na seleção de locais para barragens de rejeitos. Procura-se assim incentivar a tomada de decisões para este tipo de obra com base em métodos de análise multicriterial, incorporando os aspectos social e ambiental, e ao mesmo tempo se realiza uma aplicação inédita para o método de análise hierárquica. 


\section{OBJETIVO DA DISSERTACAO.}

O objetivo desta dissertação é a aplicação do método de análise hierárquica como apoio à tomada de decisões para a localização de barragens de contenção de rejeitos de mineração, levando em conta o maio número possível de variáveis relevantes.

O desenvolvimento do trabalho compreendeu os seguintes objetivos específicos:

- Levantar, por meio de revisão bibliográfica e entrevistas com profissionais, os dados, métodos e indicadores comumente utilizados na etapa de planejamento de procura de locais para barragens de rejeitos, bem como os critérios empregados para sua seleção.

- Familiarização com o método de análise hierárquica, sua fundamentação teórica e exemplos de aplicação.

- Apresentação de um estudo de caso.

- Aplicação do método de análise hierárquica ao estudo de caso.

- Realização de análises de sensibilidade.

- Análise crítica dos resultados. 


\section{DISPOSIÇÃO DE REJEITOS DE MINERAÇÃO.}

As atividades mineradoras geram uma grande quantidade de resíduos sólidos, dos quais os mais importantes em termos de volume são os gerados pelas atividades de extração de minério (estéreis) e pelas usinas de beneficiamento (rejeitos). Nesta pesquisa trataremos apenas da disposição dos rejeitos.

Os rejeitos são partículas sólidas resultantes da britagem, da moagem e, eventualmente, do tratamento químico do minério, sem nenhum valor econômico. A granulometria dos rejeitos varia em função do tipo de minério. Os rejeitos são transportados para os locais de disposição em tubulações, por gravidade ou por bombeamento, com grande quantidade de água. Chamase polpa a suspensão de rejeitos e água, sendo que a porcentagem de água é de aproximadamente $70 \%$.

A disposição dos rejeitos pode ser feita a céu aberto, de forma subterrânea, ou subaquática. A disposição subaquática não é muito utilizada pelos problemas ambientais que gera; os impactos aos ecossistemas aquáticos são negativos e algumas vezes irreversíveis. A disposição subterrânea é feita em câmaras que restam depois da extração do minério; os rejeitos são bombeados na maioria dos casos e depositados preenchendo essas câmaras. A disposição mais comum é a céu aberto, e pode ser feita em pilhas controladas ou em estruturas de contenção localizadas em bacias ou vales. Também existem disposições dos rejeitos vinculadas com os sistemas de extração do minério, por deposição subterrânea e a céu aberto; nesse caso, os rejeitos formam camadas de fundação para os equipamentos de extração.

Segundo Vick (1983), a estrutura de contenção é construída levantando-se inicialmente um dique de partida com solo de empréstimo, o qual deve ter uma capacidade de retenção de rejeitos para dois ou três anos de operações da lavra. Os estágios posteriores (alteamentos) podem ser construídos também com material de empréstimo, com estéreis, por deposição hidráulica de rejeitos ou por ciclonagem dos mesmos rejeitos. A ciclonagem é feita com um equipamento chamado ciclone, que separa granulometricamente, por efeitos da pressão, partículas menos densas e finas de partículas mais densas e grossas. A polpa de rejeitos entra no ciclone e é separada em dois fluxos: "overflow", composto de partículas mais finas e 
menos densas que saem pela parte superior do ciclone e "underflow", de partículas mais grossas e mais densas que saem pela parte inferior do ciclone.

Os alteamentos podem assumir diferentes configurações, cada uma com suas características, especificações, vantagens e desvantagens. Os métodos de alteamento são geralmente classificados em três classes: método de montante, método da jusante e método da linha de centro. Os nomes referem-se à direção em que os alteamentos são feitos em relação ao dique inicial.

\subsection{Método de montante.}

Na Figura 3 é apresentado o método de montante. Inicialmente é construído o dique de partida e nos alteamentos o eixo da barragem se desloca para montante.

A polpa é descarregada ao longo do perímetro da crista do dique, formando uma praia. A descarga pode ser feita com ciclones, ou com uma seqüência de tubulações menores perpendiculares à tubulação principal, chamados "spigots", que permitem uma melhor uniformidade na formação da praia. Como os rejeitos têm uma distribuição granulométrica ampla, as partículas mais grossas e mais pesadas sedimentam mais rapidamente, ficando nas zonas perto do dique, e as partículas menores e menos densas ficam em suspensão e são transportadas para as zonas internas da bacia de sedimentação.

Nas etapas posteriores, são construídos diques em todo o perímetro da bacia. O tamanho dos diques nos alteamentos é uma variável que depende das necessidades operacionais da mina. $\mathrm{O}$ dique inicial geralmente é sempre maior que os diques das etapas seguintes.

Se os alteamentos forem construídos com rejeitos, é necessário que esses contenham de 40 a $50 \%$ de areia e que na descarga a polpa seja de alta porcentagem de sólidos por peso para que ocorra a segregação granulométrica; essa alta porcentagem de sólidos pode ser obtida pela ciclonagem da polpa (Vick, 1983).

Como todo método de construção, apresenta vantagens e desvantagens (Nieble 1976, Burke 1973, Vick 1981-1983, Assis e Espósito 1995, Sanchez 2000). 


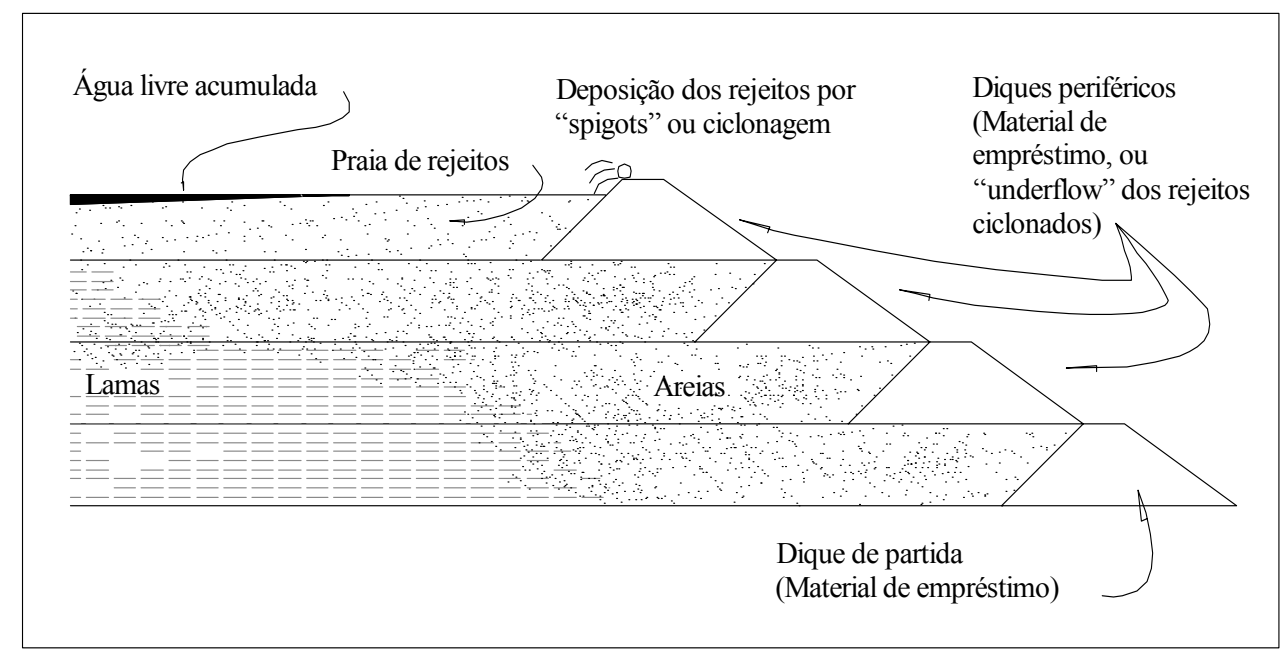

Figura 3. Método de montante (Vick 1981, modificado).

Vantagens:

- O volume de material (de rejeitos ou de empréstimo) dos alteamentos é menor.

- Menor custo de construção.

- Maior velocidade de alteamento.

- Facilidade de operação.

- Pode ser construída em topografias muito íngremes, onde o limitante principal é a área de deposição.

Desvantagens: (ver Figura 4)

- Baixa segurança (a linha freática muito próxima ao talude da jusante).

- Susceptibilidade à liquefação por sismos naturais ou por vibrações decorrentes do movimento de equipamentos, quando os alteamentos são realizados com os rejeitos, isto devido à fundação dos alteamentos ser constituída de areias saturadas fofas não compactadas e/ou não classificadas (rejeitos descarregados por "spigots").

- Quando os rejeitos não são compactados ou ligeiramente compactados, a superfície crítica de deslizamento passa pelos rejeitos sedimentados.

- Existe a possibilidade de ocorrência de "piping" devido à linha freática estar muito próxima do talude da jusante e à não compactação dos rejeitos, ou quando ocorre concentração de fluxo entre dois diques compactados. 


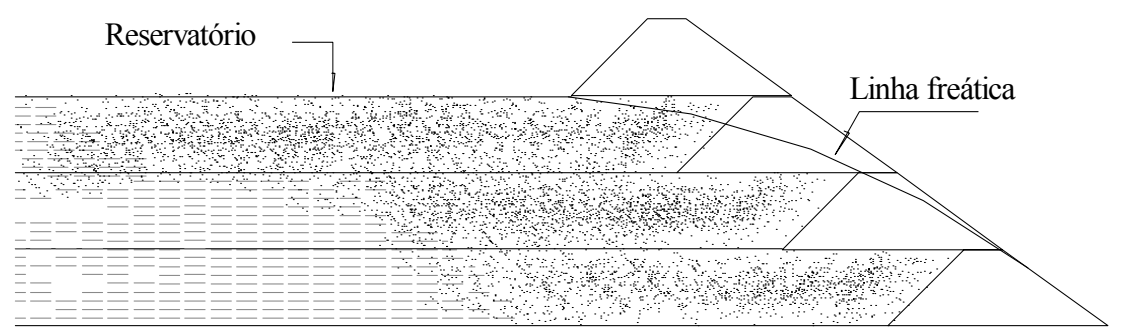

(a)
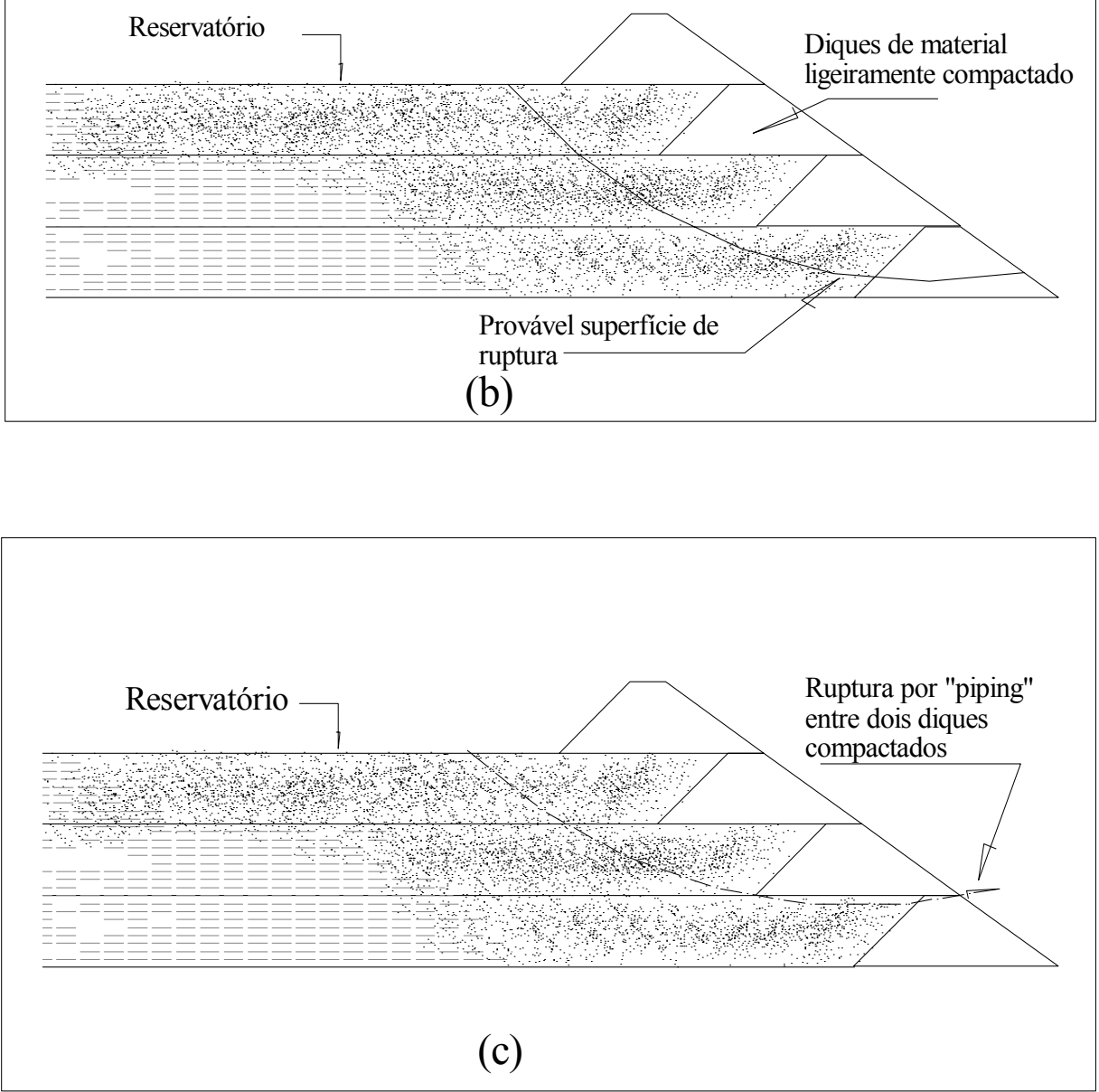

Figura 4. Desvantagens do método de montante: (a) linha freática elevada; (b) superfície provável de ruptura passa pelos rejeitos; (c) risco de ruptura por “piping” (Silveira e Reades 1973). 


\subsection{Método de Jusante.}

$\mathrm{Na}$ Figura 5 é apresentado o método da jusante; é chamado assim por que nos alteamentos o eixo da barragem se desloca para jusante. É construído um dique inicial impermeável, o qual deve ter uma drenagem interna, composta por filtro inclinado e tapete drenante. O talude interno da barragem ou talude de montante, nos alteamentos, é impermeabilizado. A drenagem interna e a impermeabilização do talude de montante não são obrigatórias se os rejeitos possuem características de alta permeabilidade e ângulo de atrito elevado.

Neste método os rejeitos são ciclonados e o "underflow" é lançado no talude da jusante. Somente são utilizados os rejeitos grossos no alteamento, os quais são compactados quando as características de umidade da zona o permitam; também se pode utilizar material de empréstimo, ou estéril proveniente da lavra.

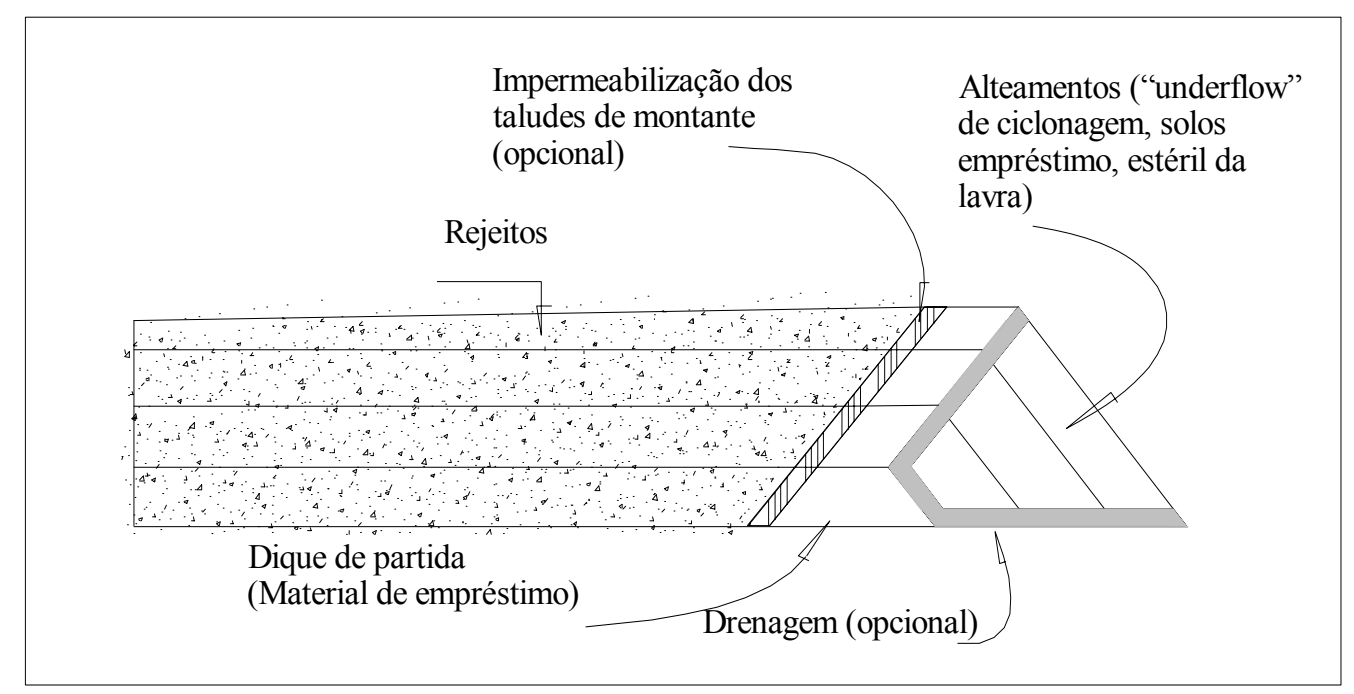

Figura 5. Método de jusante (Vick 1981, modificado).

Existem variantes do método da jusante, como mostra a Figura 6, onde são construídos um dique inicial e um dique de enrocamento; os rejeitos ciclonados vão sendo depositados entre essas duas estruturas para formar os alteamentos. Observa-se que neste método a quantidade de rejeitos para realizar os alteamentos deve ser maior do que no método de jusante convencional. A camada impermeabilizante do talude da montante é substituída por um tapete drenante do dique inicial ao dique de enrocamento, para que a linha freática não fique próxima do talude da jusante. 


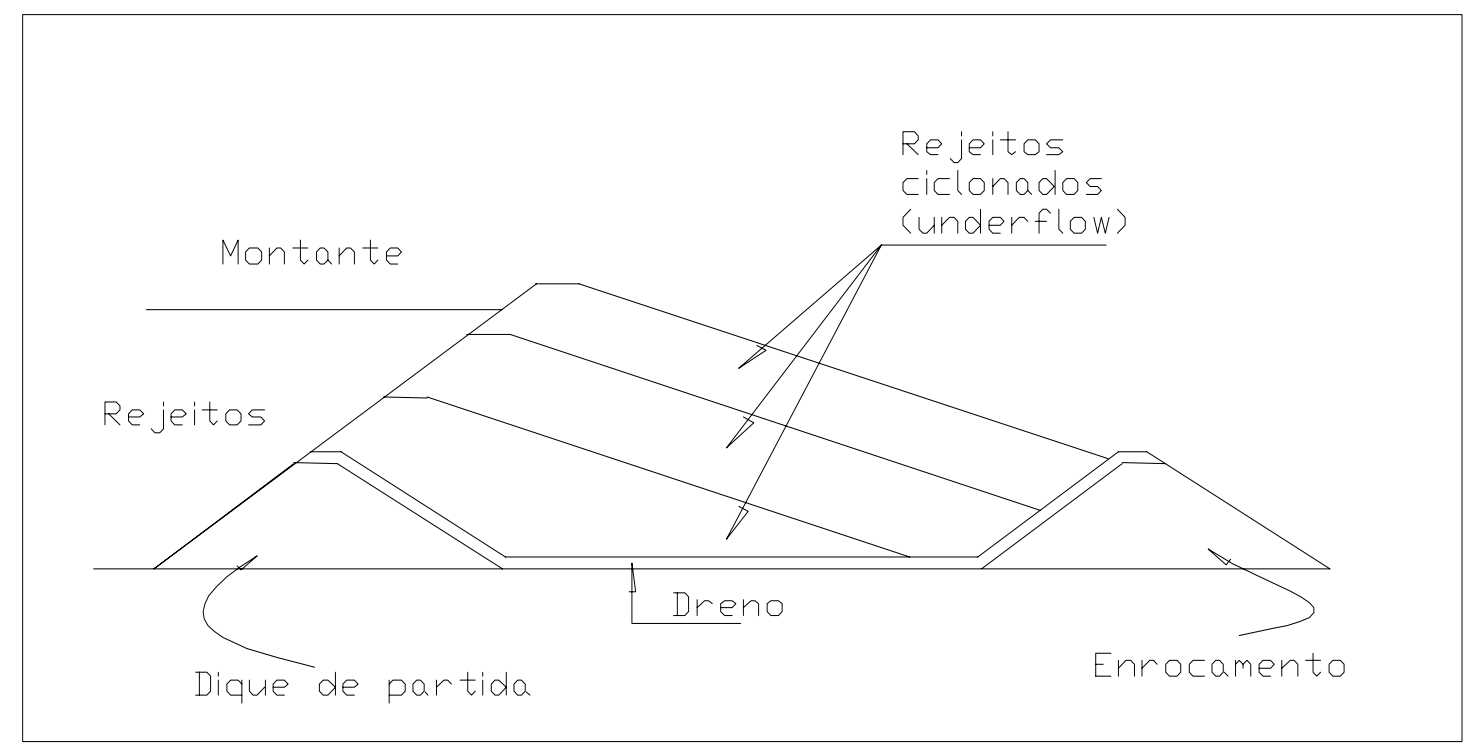

Figura 6. Método de jusante com enrocamento (Nieble 1976, modificado).

As vantagens e desvantagens do método de jusante estão apresentadas a seguir (Nieble 1976, Burke 1973, Vick 1981-1983, Assis e Espósito 1995, Sanchez 2000).

Vantagens:

- O método é eficiente para o controle das superfícies freáticas, pela construção de sistemas contínuos de drenagem.

- Pode ser usado em lugares com vibrações e/ou alta sismicidade, já que, se compactados os rejeitos do "underflow", a susceptibilidade de liquefação é muito menor.

- Operação bastante simples.

- Possibilita a compactação de todo o corpo da barragem.

- Maior segurança devido aos alteamentos controlados (disposição da fração grossa dos rejeitos a jusante, sistemas de drenagem e compactação): as probabilidades de "piping" e de rupturas horizontais são muito menores.

- O estéril proveniente da lavra pode ser utilizado, e/ou misturado nos alteamentos.

Desvantagens:

- Necessidade de grandes quantidades de rejeitos nas primeiras etapas da construção.

- Dependendo das características dos rejeitos, os problemas de área se incrementariam, devido aos taludes bastante abatidos.

- Necessidade de sistemas de drenagem eficientes, havendo probabilidade de colmatação. 
- Devido à complexidade dos diques de partida e de enrocamento e aos sistemas de drenagem, os investimentos iniciais são altos.

- Em zonas de alta pluviosidade é possível que os rejeitos a jusante não possam ser compactados adequadamente, devendo-se esperar épocas de estio para a operação de equipamentos em cima dos rejeitos.

- Não possibilita a proteção com cobertura vegetal no talude de jusante, e tampouco drenagem superficial durante a fase construtiva, devido à superposição dos rejeitos.

- É necessário o emprego de ciclones para garantir uma ótima separação dos rejeitos.

\subsection{Método da Linha de Centro.}

O método da linha de centro, chamado assim porque o eixo da barragem é mantido na mesma posição enquanto ela é elevada, é uma solução intermediária entre o método de montante e o de jusante (inclusive em termos de custo), embora seu comportamento estrutural se aproxime do método da jusante. Na Figura 7 se apresenta o método da linha do centro. Inicialmente é construído um dique de partida e o rejeito é lançado perifericamente da crista do dique até formar uma praia. $\mathrm{O}$ alteamento subseqüente é formado lançando materiais de empréstimo, estéril da mina ou "underflow" de ciclones, sobre o limite da praia anterior e no talude de jusante do maciço de partida, mantendo o eixo coincidente com o eixo do dique de partida.

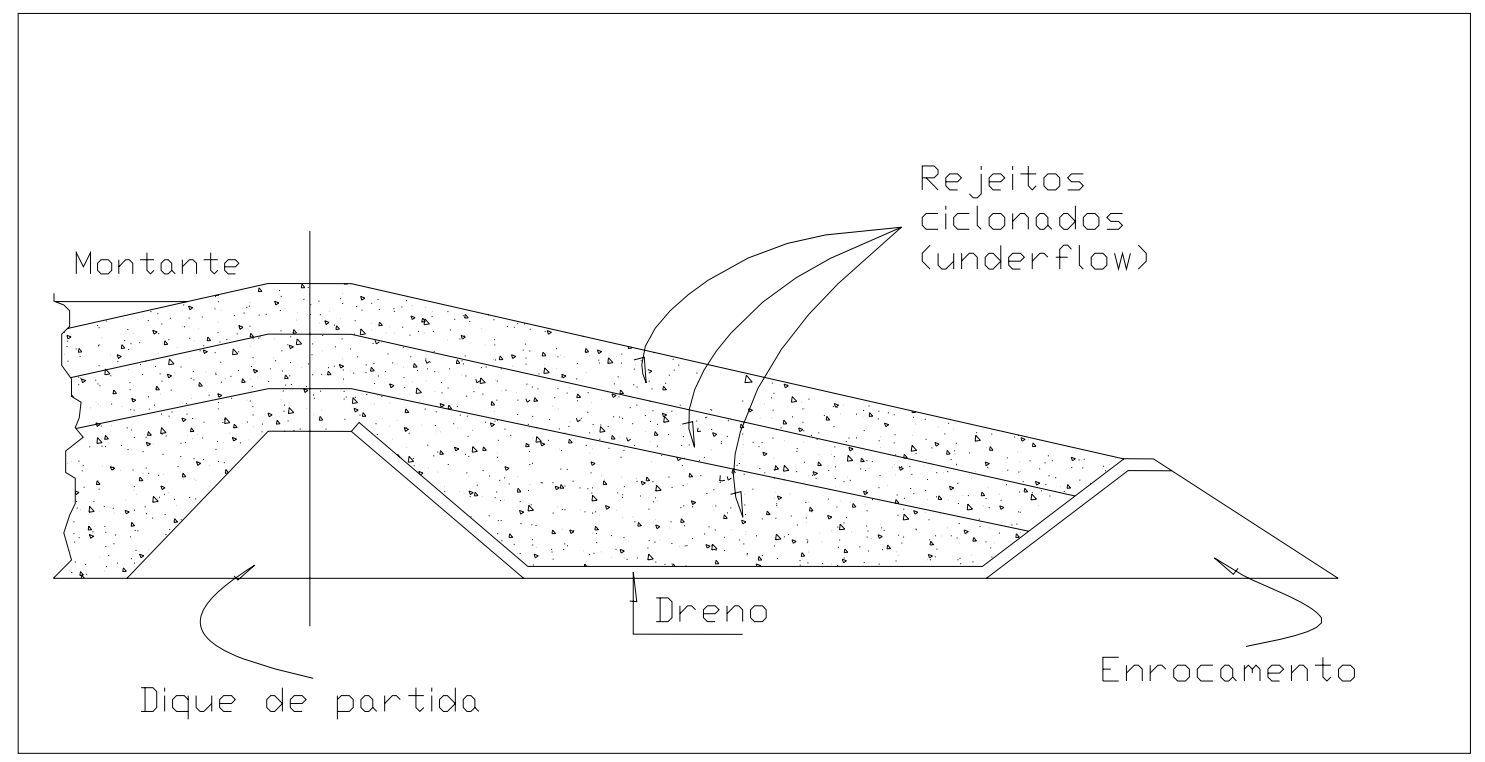

Figura 7. Método da linha de centro (Nieble 1976, modificado). 
Por ser uma combinação dos dois métodos descritos anteriormente, as vantagens e desvantagens são similares às dos mesmos, tentando minimizar as desvantagens.

Vantagens:

- Facilidade na construção.

- Eixo dos alteamentos constante.

- Redução do volume de "underflow necessário" em relação ao método da jusante.

Desvantagens:

- Necessidade de sistemas de drenagem eficientes e sistemas de contenção a jusante (se o material de rejeito fica saturado a jusante, pode comprometer a estabilidade do maciço).

- Operação complexa; é necessário equipamento para deposição mecânica a jusante.

- Pela complexidade da operação, os investimentos globais podem ser altos.

$\mathrm{Na}$ Tabela 2 apresentam-se as características principais, aspectos de segurança, e os custos relativos em função ao volume da barragem alteada pelo método de montante; são feitas também comparações com as barragens de terra convencionais para armazenamento de água. Na Tabela 3 se sintetizam os métodos construtivos dos três tipos de barragens descritos, além de algumas das vantagens e desvantagens. Na Figura 8 são apresentadas comparações de área de seção transversal dos três tipos de barragens de rejeitos, com mesma altura e capacidade de deposição de rejeitos.

Como se viu anteriormente, o método de jusante tem as melhores características de estabilidade; porém, o volume necessário de "underflow", material de empréstimo ou estéril da lavra, é três vezes o do método de montante, o que se relaciona, logicamente, com os custos do projeto total.

Deve-se observar que as características das barragens construídas com rejeitos são diferentes das construídas com materiais de comportamento geotécnico melhor, como solos de empréstimo ou estéril proveniente da lavra. Quando os alteamentos são feitos com os rejeitos, o corpo da barragem se comporta como um aterro hidráulico, onde o material é lançado de uma forma quase aleatória, sem controle das variáveis que influenciam o processo de deposição. 
Tabela 2. Comparação entre as características das barragens de rejeitos (Vick 1983, modificado).

\begin{tabular}{|c|c|c|c|c|}
\hline & Convencional & Montante & Jusante & Linha de centro \\
\hline $\begin{array}{l}\text { Tipo de rejeito } \\
\text { recomendado }\end{array}$ & •Qualquer tipo & $\begin{array}{l}\text { - Mais de } 40 \% \text { de areia } \\
\text {-Baixa densidade de } \\
\text { polpa para promover } \\
\text { segregação }\end{array}$ & $\begin{array}{l}\bullet \text { Qualquer } \\
\text { tipo }\end{array}$ & $\begin{array}{c}\text { - Areias ou lamas } \\
\text { de baixa } \\
\text { plasticidade }\end{array}$ \\
\hline $\begin{array}{l}\text { Requerimentos de } \\
\text { descarga dos } \\
\text { rejeitos }\end{array}$ & $\begin{array}{c}\bullet \text { Qualquer } \\
\text { procedimento de } \\
\text { descarga }\end{array}$ & $\begin{array}{l}\text {-Descarga periférica, } \\
\text { e bom controle de } \\
\text { água livre acumulada }\end{array}$ & $\begin{array}{l}\bullet \text { De acordo } \\
\text { com o projeto }\end{array}$ & $\begin{array}{c}\text {-Descarga } \\
\text { periférica, } \\
\text { conservando o } \\
\text { eixo da barragem }\end{array}$ \\
\hline $\begin{array}{c}\text { Armazenamento } \\
\text { d’água }\end{array}$ & -Boa & $\begin{array}{c}\bullet \text { Não recomendado } \\
\text { para grandes volumes }\end{array}$ & -Boa & $\begin{array}{c}\bullet \text { Não } \\
\text { recomendado para } \\
\text { armazenamento } \\
\text { permanente } \\
\end{array}$ \\
\hline Resistência sísmica & $\bullet$ Boa & $\begin{array}{c}\text {-Fraca em áreas de } \\
\text { alta sismicidade }\end{array}$ & -Boa & -Aceitável \\
\hline $\begin{array}{l}\text { Restrições de } \\
\text { alteamento }\end{array}$ & $\begin{array}{c}\text {-De uma só vez, } \\
\text { ou em poucas } \\
\text { etapas }\end{array}$ & $\begin{array}{c}\text { •Recomendável } \\
\text { menos de } 5 \text { a } 10 \\
\text { m/ano, perigoso mais } \\
\text { alto que } 15 \mathrm{~m} / \text { ano }\end{array}$ & •Nenhuma & •Pouca \\
\hline $\begin{array}{l}\text { Requisitos de } \\
\text { alteamento }\end{array}$ & $\begin{array}{c}\bullet \text { Materiais } \\
\text { naturais e/ou } \\
\text { estéril }\end{array}$ & $\begin{array}{c}\bullet \text { Solo natural } \\
\bullet \text { Rejeitos ou estéril }\end{array}$ & $\begin{array}{l}\bullet \text { Rejeitos ou } \\
\text { estéril }\end{array}$ & •Rejeitos ou estéril \\
\hline $\begin{array}{l}\text { Custo relativo do } \\
\text { corpo do aterro }\end{array}$ & -Alto $\left(3 \mathrm{~V}_{\mathrm{m}}{ }^{*}\right)$ & -Baixo $\mathrm{V}_{\mathrm{m}}$ & -Alto $\left(3 \mathrm{~V}_{\mathrm{m}}\right)$ & -Moderado $\left(2 \mathrm{~V}_{\mathrm{m}}\right)$ \\
\hline
\end{tabular}

$* \mathrm{~V}_{\mathrm{m}}=$ volume da barragem alteada pelo método de montante

Tabela 3. Vantagens e desvantagens dos três tipos de barragens de rejeitos (Soares 2004, modificado).

\begin{tabular}{|c|c|c|c|}
\hline & Método de montante & Método de jusante & Método da linha de centro \\
\hline 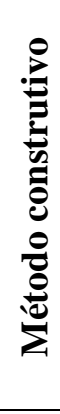 & $\begin{array}{l}\text {-Método mais antigo, e o mais } \\
\text { empregado. } \\
\text { •Construção de dique inicial e os } \\
\text { diques do alteamento periféricos } \\
\text { com material de empréstimo, } \\
\text { estéreis da lavra ou com } \\
\text { "underflow" de ciclonagem. } \\
\text {-Lançamento a partir da crista por } \\
\text { ciclonagem ou "spigots". }\end{array}$ & $\begin{array}{l}\text { •Construção de dique inicial } \\
\text { impermeável e barragem de } \\
\text { pé. } \\
\text { •Separação dos rejeitos na } \\
\text { crista do dique por meio de } \\
\text { hidrociclones. } \\
\text { •Dreno interno e } \\
\text { impermeabilização a } \\
\text { montante. }\end{array}$ & $\begin{array}{l}\text { •Variação do método de } \\
\text { jusante. }\end{array}$ \\
\hline 昰 & $\begin{array}{l}\text {-Menor custo. } \\
\text { •Maior velocidade de alteamento. } \\
\text {-Utilizado em lugares onde há } \\
\text { limitante de área. }\end{array}$ & $\begin{array}{l}\text {-Maior segurança. } \\
\text { - Compactação de todo o } \\
\text { corpo da barragem. } \\
\text {-Pode-se misturar os estéreis } \\
\text { da lavra. } \\
\end{array}$ & $\begin{array}{l}\text { •Variação do volume de } \\
\text { "underflow" necessário com } \\
\text { relação ao método da jusante. }\end{array}$ \\
\hline مِّ & $\begin{array}{l}\text {-Baixa segurança devido à linha } \\
\text { freática próxima ao talude de } \\
\text { jusante, susceptibilidade de } \\
\text { liquefação, possibilidade de } \\
\text { "piping". }\end{array}$ & $\begin{array}{l}\text { •Necessidade de grandes } \\
\text { quantidades de "underflow" } \\
\text { (problemas nas } 1^{\text {as }} \text { etapas). } \\
\text { •Deslocamento do talude de } \\
\text { jusante (proteção superficial } \\
\text { só no final da construção). }\end{array}$ & $\begin{array}{l}\text { - Necessidade de sistemas de } \\
\text { drenagem eficientes e } \\
\text { sistemas de contenção a } \\
\text { jusante }\end{array}$ \\
\hline
\end{tabular}




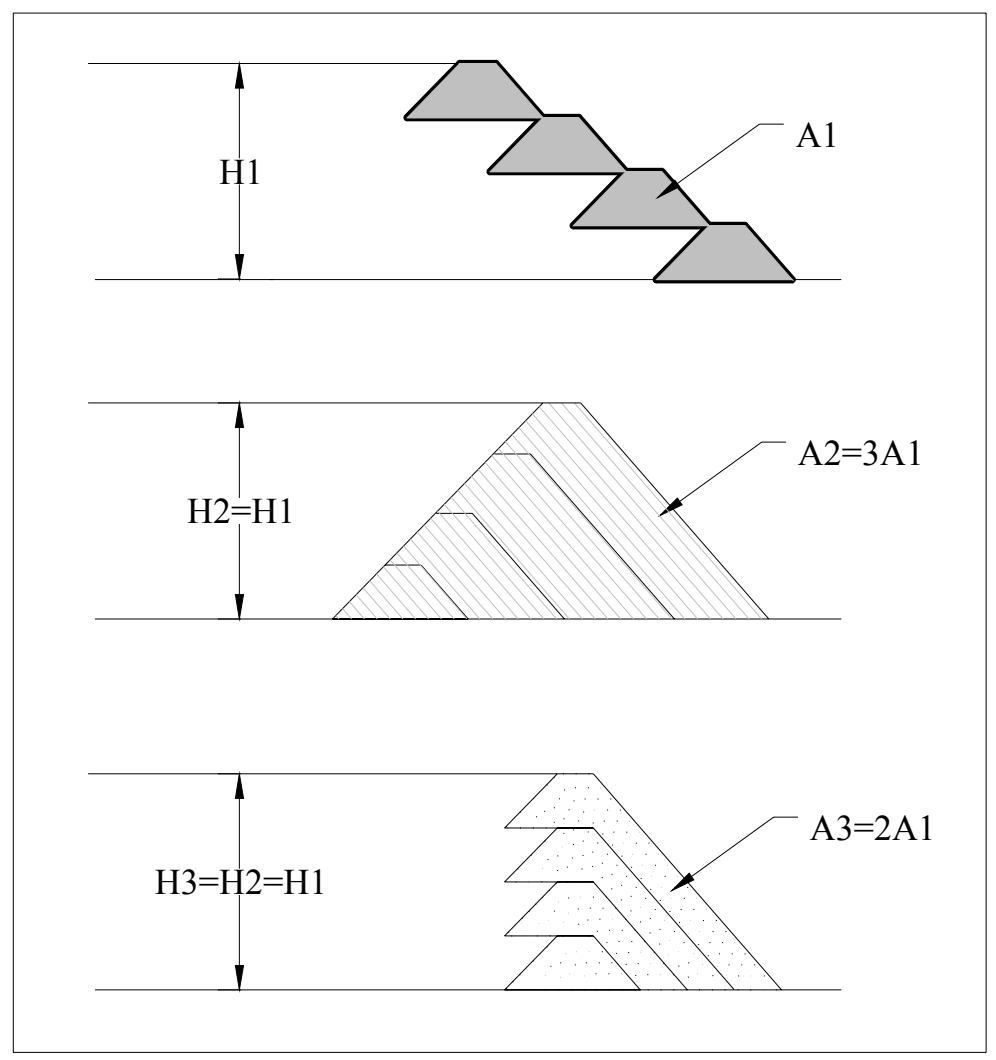

Figura 8. Comparação de volumes para vários tipos de barragem: (a) Método de montante. (b) Método de jusante. (c) Método da linha do centro (Vick 1983, modificado).

As propriedades do aterro hidráulico dependem do método de deposição e da composição da polpa (tipo de fluido de transporte, distribuição granulométrica, geometria dos grãos, textura e densidade, porcentagem de sólidos por peso da polpa), que definem o comportamento de segregação da polpa na deposição, influenciando a geometria da estrutura do corpo da barragem. Na Tabela 4 são apresentados alguns exemplos de seções transversais típicas onde a segregação dos materiais, pelas suas características, muda a geometria da deposição. Dois estudos detalhados aplicados a rejeitos de mineração como material da estrutura são apresentados por Espósito (2000) e Ribeiro (2000)

\subsection{Deposição subterrânea (disposição em cavas de mineração).}

A deposição subterrânea pode ter certos méritos em casos especiais, nos quais os rejeitos podem ser considerados inertes e sem perigos potenciais. No entanto, muitos rejeitos com o tempo podem gerar poluentes (por exemplo, a percolação d'água através dos rejeitos pode dissolver vários poluentes metálicos, pode ocorrer oxidação de enxofre e produção de ácidos, por redução do $\mathrm{pH}$ ), e, portanto, contaminar águas subterrâneas. Os rejeitos podem ser 
bombeados diretamente na cava da mina, ou pode-se retirar água dos mesmos para melhorar suas características de deposição; isto depende dos métodos de extração do minério.

Tabela 4. Seções transversais típicas de aterros hidráulicos (Espósito 2000, modificado).

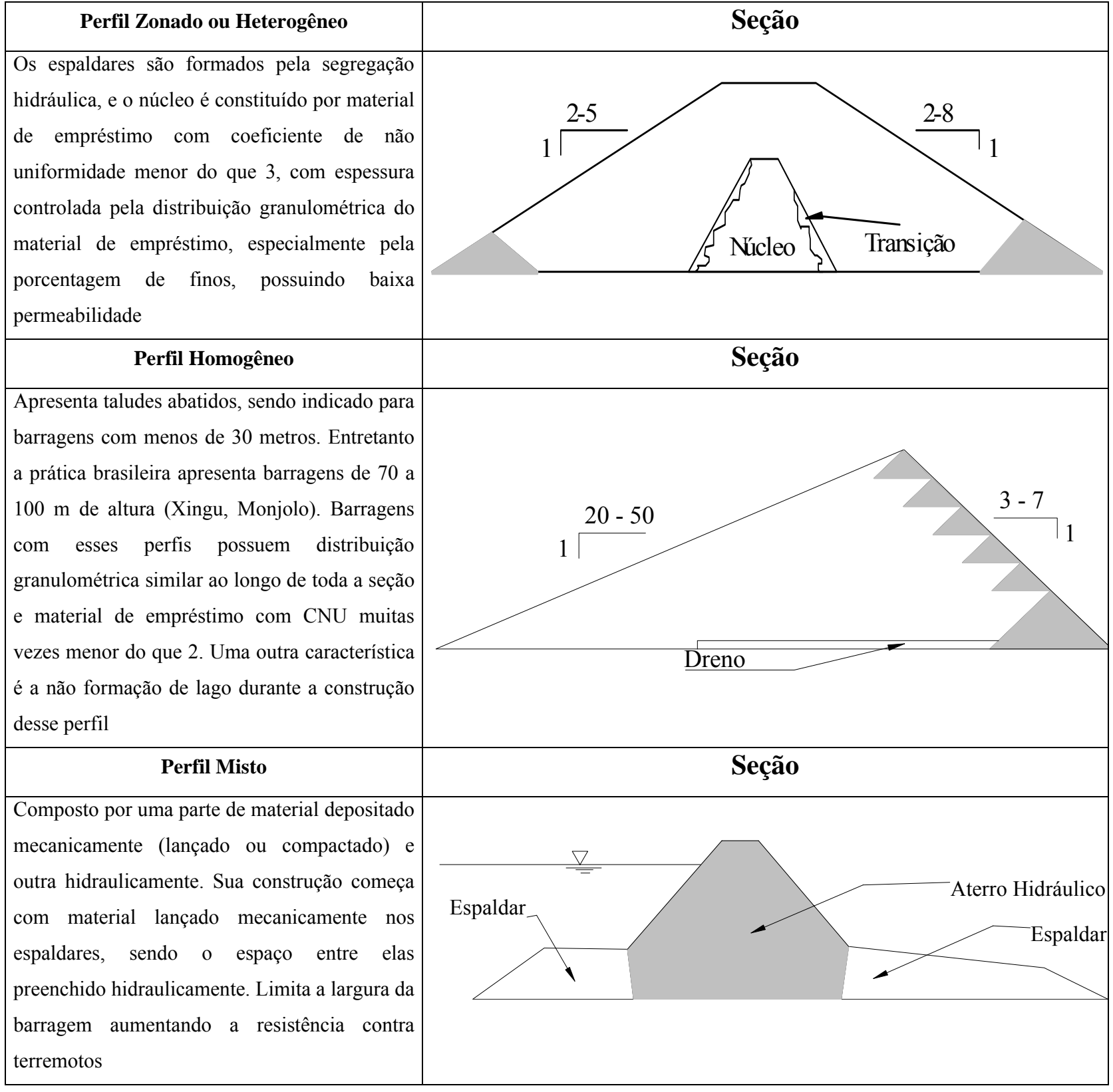

Segundo Vick (1983), o retorno dos rejeitos à mina é feito comumente por um ou mais dos seguintes três propósitos:

- Proporcionar um piso de trabalho para as atividades de extração de minério.

- Proporcionar suporte às paredes das escavações subterrâneas.

- Maximizar a recuperação do corpo do minério. 
Além disso, os próprios rejeitos devem apresentar alta permeabilidade, baixa compressibilidade e alta rigidez. Pode-se conseguir baixa compressibilidade removendo os finos da polpa ou por compactação vibratória, que também aumenta a densidade do rejeito.

\subsection{Deposição em “pit” (Processos de extração de minério a céu aberto).}

Este tipo de deposição é feito tipicamente em minas a céu aberto onde não é necessária a construção de diques. Na Figura 9 são apresentados os dois tipos de deposições, quando a extração do minério foi completa (Figura 9a), e quando a deposição é feita ao mesmo tempo do que a extração de minério (Figura 9b). A Figura 10 ilustra um caso de aplicação numa mina nos Estados Unidos.

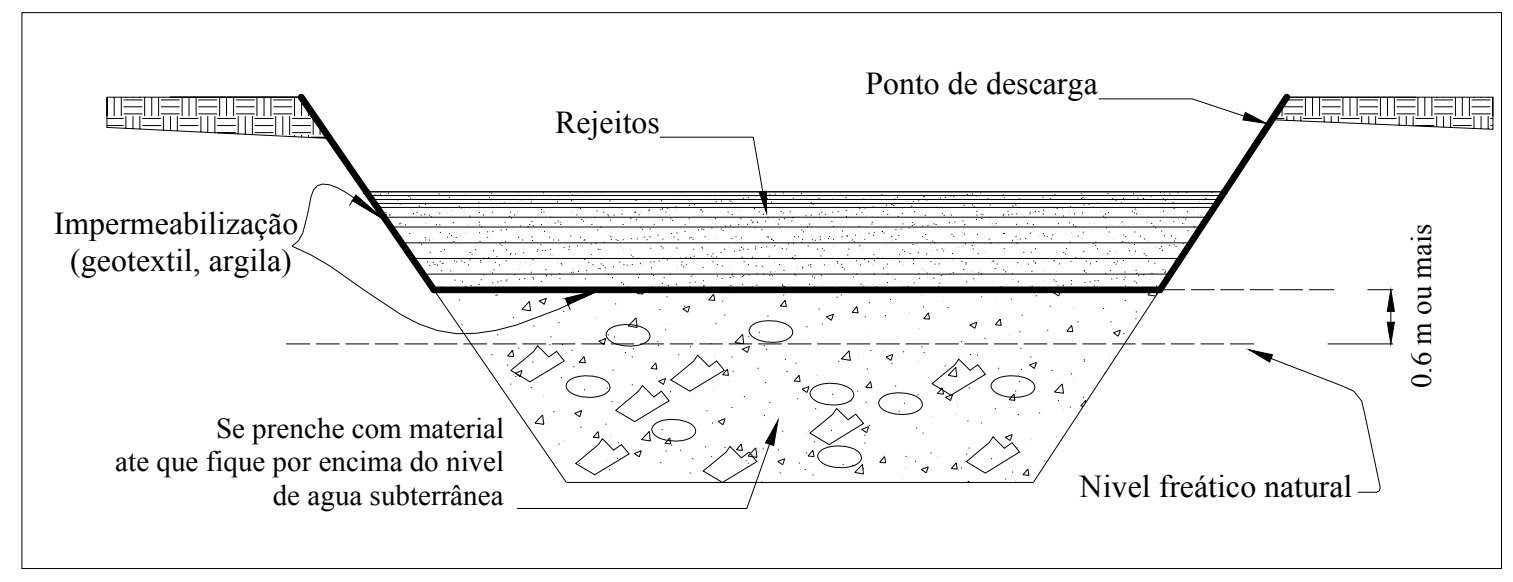

(a)

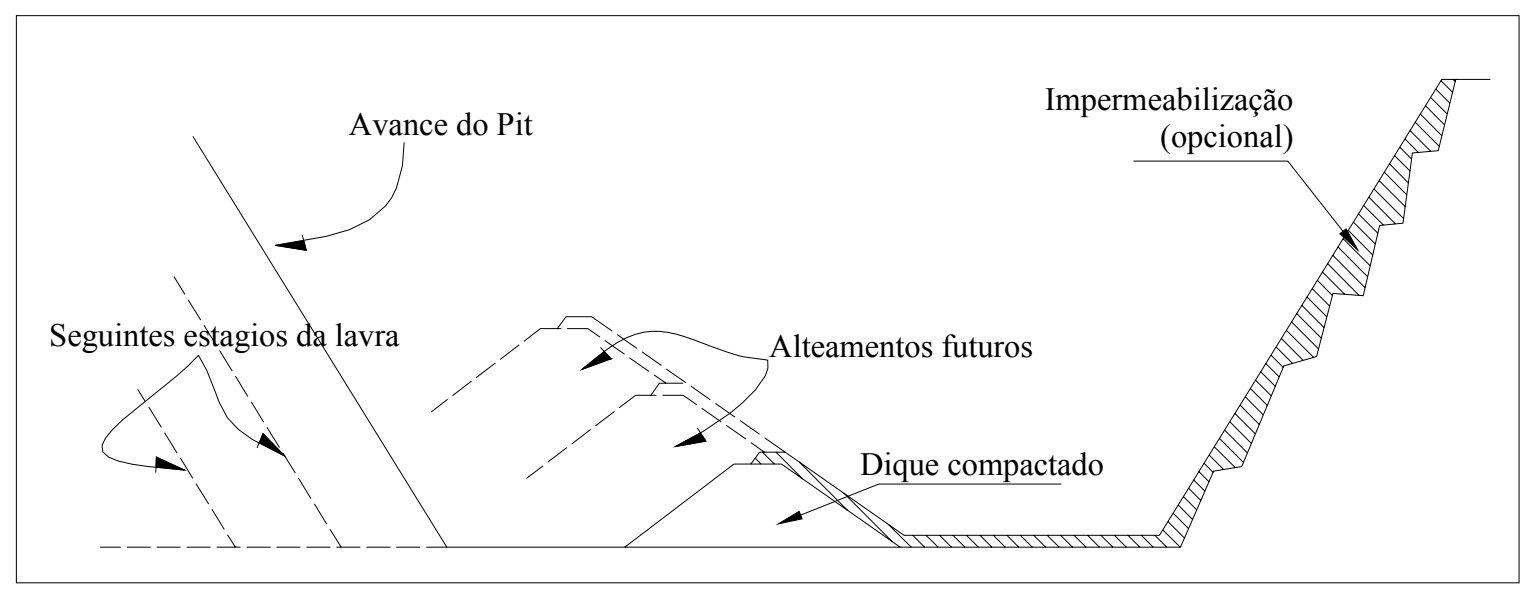

(b)

Figura 9. Deposição em “pit”: (a) Extração do minério total. (b) Deposição feita ao mesmo tempo do que a extração do mineiro ( Ritcey 1989, modificado). 


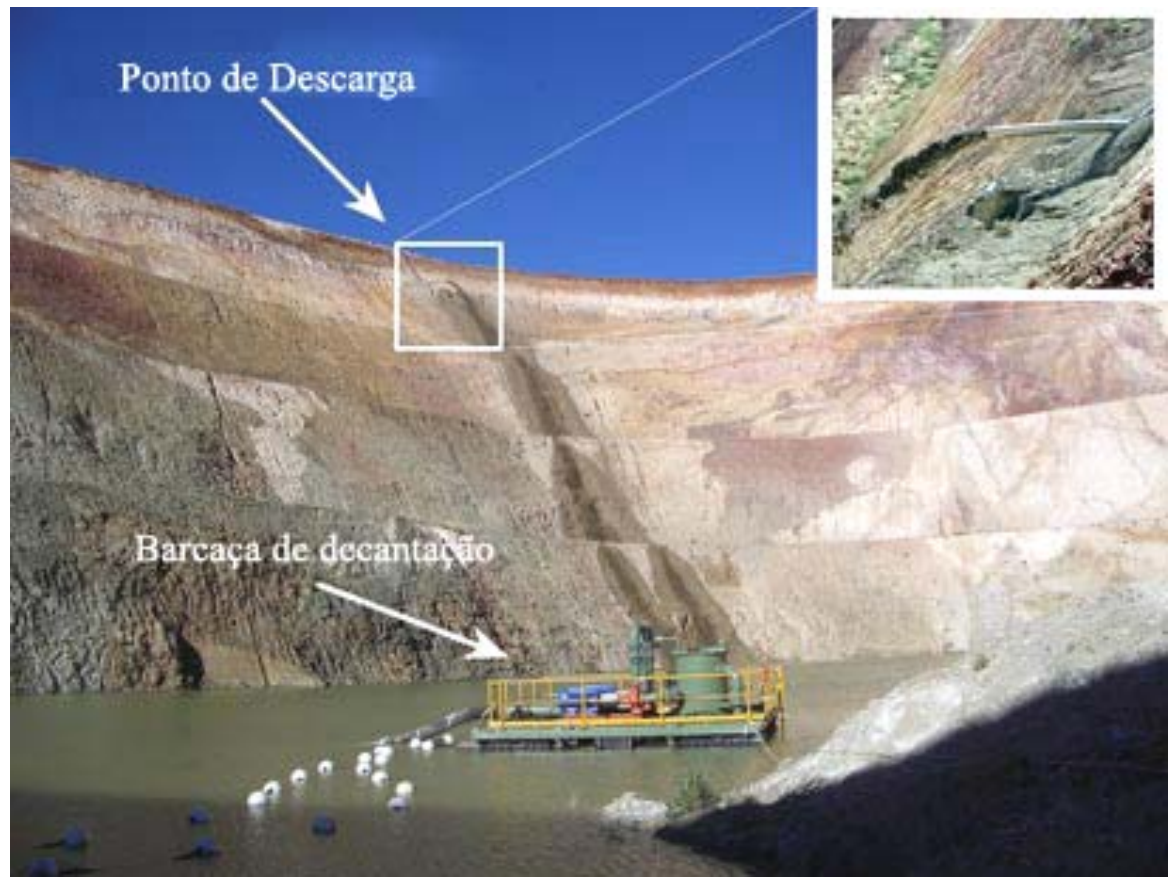

Figura 10. Deposição em “pit”.

Ritcey (1989) descreve algumas características na deposição de rejeitos em "pit":

- O projeto de cobertura final é fácil, se assegura mínima erosão e boa drenagem.

- Mínima poluição de ar.

- A extração pode ser feita por um tempo, e depois os rejeitos são depositados. É construído usualmente um pequeno "pit" que é usado nos primeiros estágios da deposição de rejeitos.

- Tem um mínimo de risco de falha, exceto pela estabilidade dos taludes internos do "pit".

Os parâmetros hidrogeológicos, considerando migração de poluentes e percolação, não são conhecidos com exatidão, então se a rocha de encaixe do minério não for suficientemente impermeável, precisa-se de impermeabilização (geomembrana ou argilas) nos taludes do "pit".

\subsection{Deposição em pilhas controladas.}

Segundo Sanchez (2000), as pilhas são sistemas de deposição de rejeitos em que inicialmente extrai-se a água da polpa e a fração sólida é armazenada ou conformada em pilhas em locais adequados. Para garantir a estabilidade de longo prazo da pilha, os rejeitos têm que ser misturados com material de empréstimo para melhorar a resistência (dependendo dos rejeitos, pode ser necessário misturar finos ou materiais granulares), ou deve haver uma separação 
prévia da fração argilosa. A extração de água e a separação da fração argilosa geralmente se fazem em barragens de rejeitos já construídas; é escavado o material já seco, que é então transportado em caminhões e deposto em pilhas controladas, enquanto a cavidade formada na barragem é novamente utilizada para deposição de rejeitos recentes.

Vick (1983) se refere a outro mecanismo para baixar a umidade dos rejeitos, que é feito em correias filtrantes e bombas de vácuo. A umidade se reduz de 50\% a 20-30\%, os rejeitos são transportados pelas mesmas correias e depostos nas pilhas controladas, mas os custos de operação e manutenção do equipamento são muito altos.

Os componentes de uma pilha controlada são: dique de partida (que neste caso é um dique de menores dimensões), drenos periféricos na pilha, drenos internos, e drenos superficiais se a pilha é construído num talude. As vantagens deste tipo de deposição são ambientais, pois as pilhas podem ser construídas sem interferir com a rede de drenagem, e econômicas, pois não há necessidade de sistemas extravasores (Sanchez, 2000). 


\section{FATORES QUE INFLUENCIAM A ESCOLHA DO LOCAL DE IMPLANTAÇÃO DE BARRAGENS DE CONTENÇÃO DE REJEITOS.}

São muitas as variáveis que se consideram na escolha de locais para a implantação de barragens de rejeitos. A seguir, é apresentada uma revisão dos principais fatores a considerar neste tipo de tomada de decisões a partir da experiência de alguns autores reconhecidos, que servirá de base para a aplicação da metodologia de tomada de decisões por análise hierárquica na seleção de áreas para barragens de rejeitos.

\subsection{Brawner e Campbell (1973).}

Brawner e Campbell enfatizam que cada mina e cada local tem características diferentes e únicas, e sugerem um guia que serve como base para o projeto e planejamento da construção da barragem de rejeitos, apresentado na Figura 11. É importante notar que cada projeto tem que minimizar as perdas e maximizar os benefícios dentro dos requerimentos de estabilidade, segurança e aspetos ambientais, e deve ser baseado nas condições do local, nos custos e tempo de construção, e na produção da mina.

Para empresas que ainda não têm um projeto definido, há na Figura 11 um retângulo de linhas tracejadas que corresponde à etapa inicial de prospecção, estimativa de reservas, análise econômica, quantidade de rejeitos que serão produzidos, isto é, todos os estudos prévios de viabilidade do projeto da jazida.

O planejamento e o projeto da barragem de rejeitos devem incluir programas de ensaios em campo e em laboratório das fundações, rochas e materiais de empréstimo, para avaliar suas propriedades físicas e mecânicas, além das características das águas subterrâneas, sua localização e composição. No planejamento de uma barragem de rejeitos, são fundamentais análises de estabilidade, previsão de recalques, estudo da percolação, controle de erosão, estudo de impactos ambientais e de recuperação ambiental. Na etapa de construção, a instrumentação de campo é importante para assegurar que a obra cumpra as especificações de projeto. 


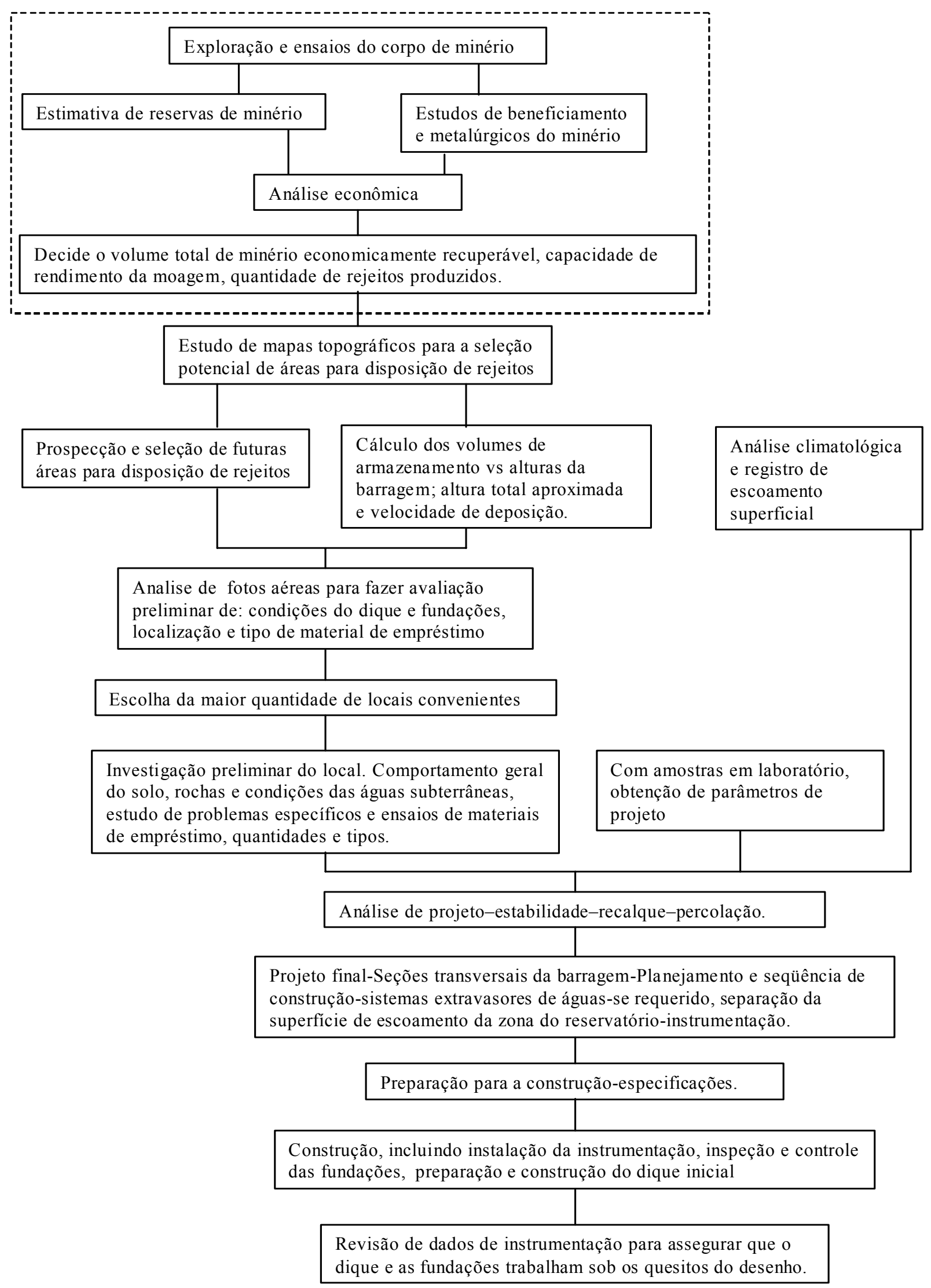

Figura 11. Programa de planejamento e projeto de uma barragem de rejeitos (Brawner e Campbell, 1973). 


\subsection{Vick (1981-1983).}

Os fatores que determinam o local da barragem não são fixos. A descoberta de aspectos geológicos e/ou condições das águas subterrâneas adversos, ou ainda a incapacidade de identificar locais em superfície viáveis econômica e tecnicamente, fazem necessário avaliar outras formas de disposição de rejeitos, como a disposição subterrânea, em "pit" ou em pilhas controladas. Na Tabela 5, são apresentados os fatores que, segundo Vick (1981-1983), influenciam a escolha do local para a construção da barragem de rejeitos.

Tabela 5. Fatores que influenciam a escolha do local para barragem de rejeitos (Vick 1981-1983, modificado).

\begin{tabular}{|l|l|}
\hline \multicolumn{1}{|c|}{ Parâmetro } & \multicolumn{1}{c|}{ Efeitos } \\
\hline $\begin{array}{l}\text { Local e elevação relativa da } \\
\text { usina de beneficiamento }\end{array}$ & $\begin{array}{l}\text {-Comprimento da tubulação de condução dos rejeitos e } \\
\text { retorno de água. } \\
\text {-Custos de operação dos mecanismos de bombeamento. }\end{array}$ \\
\hline Topografia & $\begin{array}{l}\text {-Arranjo da barragem } \\
\text {-Especificações de deposição e preenchimento da barragem. } \\
\text {-Facilidade de mudança na disposição }\end{array}$ \\
\hline Hidrologia e área de captação & $\begin{array}{l}\text {-Tempo de acumulação de água suficiente para permitir a } \\
\text { sedimentação. } \\
\text { - Especificações de manejo de inundações }\end{array}$ \\
\hline Geologia & $\begin{array}{l}\text {-Viabilidade de materiais de empréstimo, tipos e quantidades. } \\
\text {-Perdas por percolação, permeabilidades. }\end{array}$ \\
\hline Águas subterrâneas & $\begin{array}{l}\text {-Estabilidade das fundações } \\
\text {-Falhas, sismicidade, estruturas de contenção de taludes de } \\
\text { corte }\end{array}$ \\
\hline Clima & $\begin{array}{l}\text {-Vazão e direção de percolação } \\
\text {-Potencial de contaminação } \\
\text {-Teor de umidade de materiais de empréstimo. }\end{array}$ \\
\hline
\end{tabular}

A viabilidade de um local pode ser função do arranjo em planta da barragem de rejeitos, o qual deve ser compatível com a configuração topográfica. Vick (1983) define algumas categorias gerais:

- Represamento tipo anel:

A melhor locação deste tipo de arranjo é em terrenos planos, onde há ausência de depressões topográficas naturais. Requer grande quantidade de material de aterro em relação à quantidade de volume represado. Como todos os lados da estrutura são fechados, são eliminadas as contribuições externas da bacia hidrográfica, reduz-se a percolação, e só é acumulada a água da polpa que cai diretamente na barragem. Este tipo de represamento é 
usualmente ordenado numa geometria regular. Na Figura 12 é apresentado esquematicamente este tipo de represamento, de tipo simples (Figura 12a) e segmentado (Figura 12b), e na Figura 13, uma aplicação real.

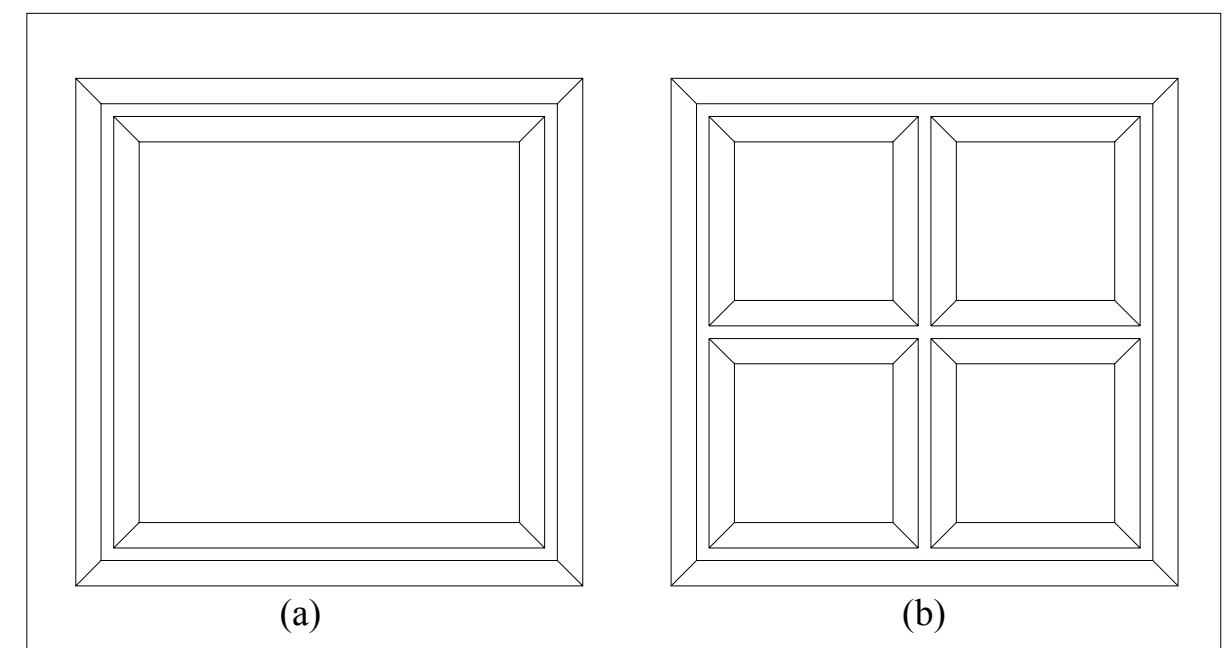

Figura 12. Represamento em anel: (a) simples. (b) múltiplos (Vick 1983).

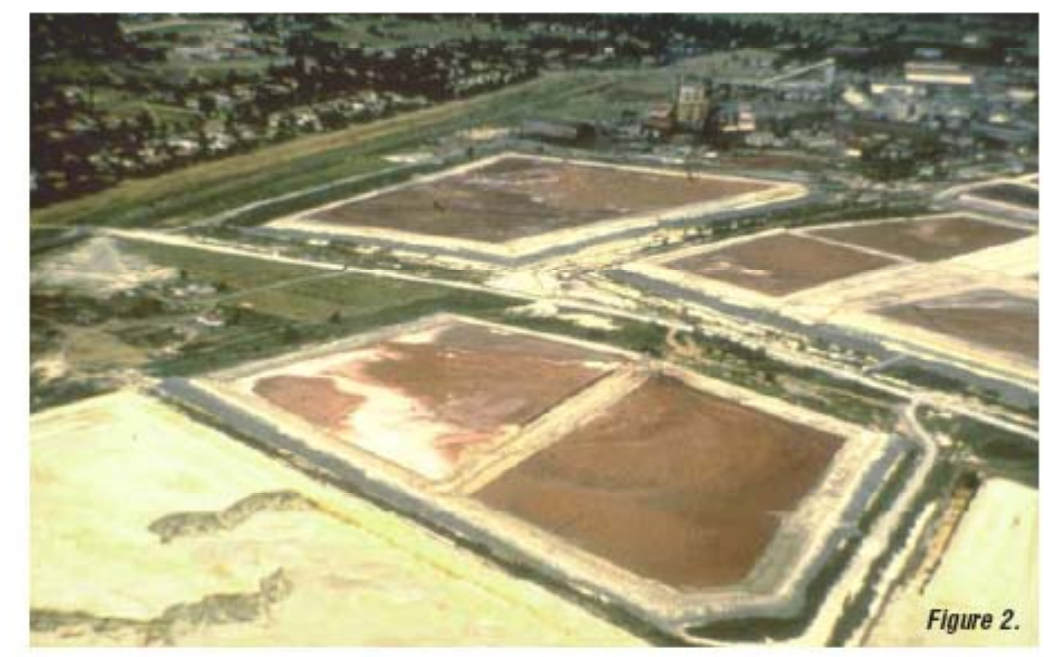

Figura 13. Represamento em anel: vista aérea (ICME-UNEP 1998).

- Represamento em bacia:

Na disposição espacial não difere das barragens convencionais para represamento de água: os rejeitos são confinados por uma barragem perpendicular ao fluxo da bacia. A barragem fica localizada numa única depressão topográfica, e pode-se dispor em uma ou várias etapas, conforme mostrado na Figura 14. A Figura 15 apresenta como exemplo a barragem de rejeitos de minério de ouro em Minas Gerais da empresa Rio Paracatu Mineração do grupo Rio Tinto Brasil. O mais importante para a estabilidade deste tipo de arranjo é o controle de água, tendo- 
se que construir obras adicionais de drenagem a montante, para impedir a entrada de água da bacia, principalmente se os alteamentos da barragem se realizam pelo método da montante.

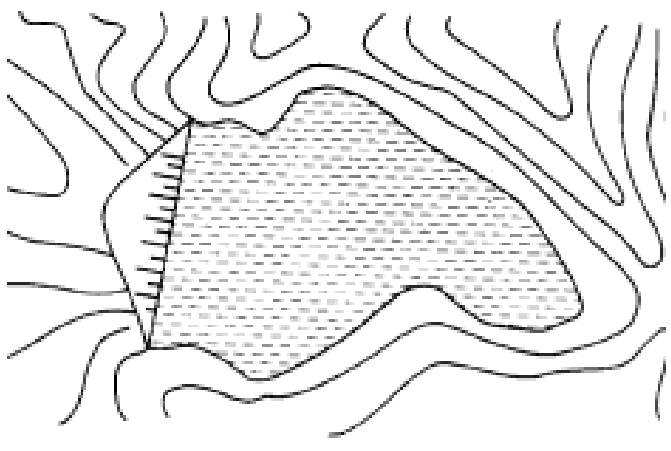

(a)

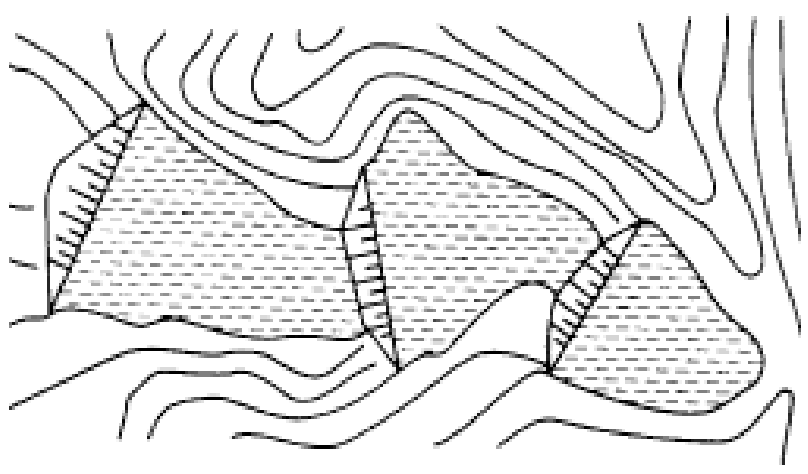

(b)

Figura 14. Represamento em bacia: (a) simples. (b) múltiplos (Vick 1983).

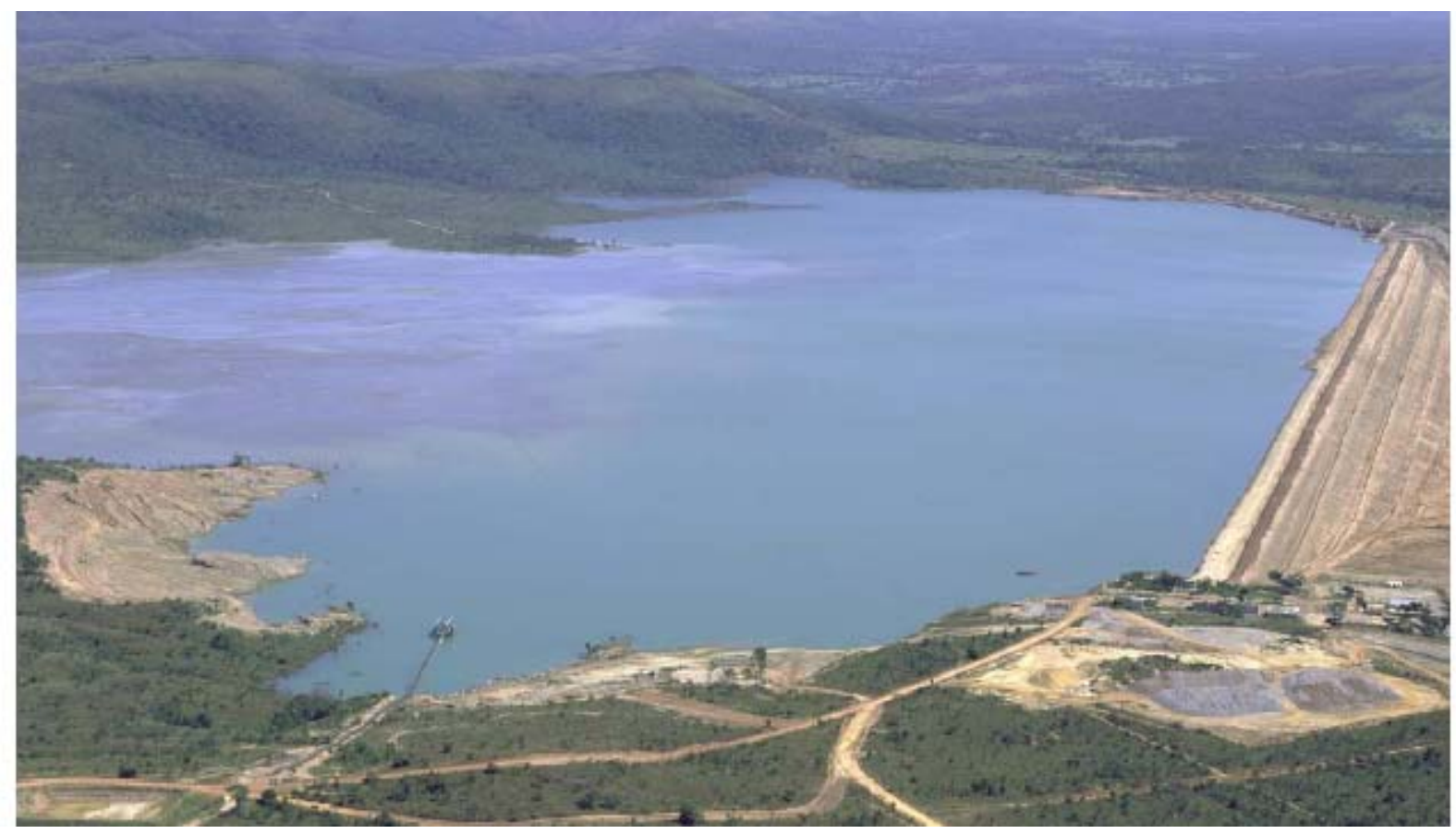

Figura 15. Represamento em bacia: mineração de ouro, Rio Paracatu Mineração, Minas Gerais (ICMEUNEP 1998).

- Represamento a meia encosta:

Este arranjo pode ser usado quando não há drenagem natural na zona de deposição dos rejeitos, e quando os taludes mais íngremes da encosta têm inclinação menor do que $10 \%$. O volume de material de aterro pode chegar a ser excessivo em relação aos volumes de deposição e armazenamento de rejeitos. Este tipo de represamento é apresentado esquematicamente na Figura 16. 


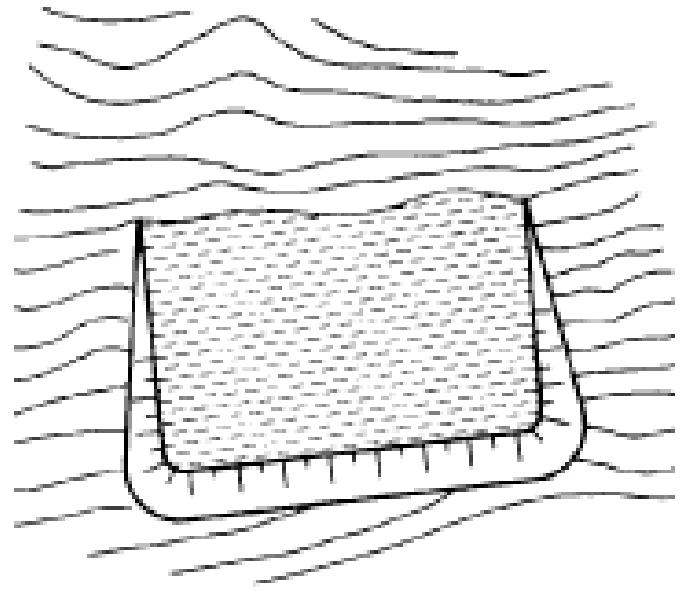

(a)

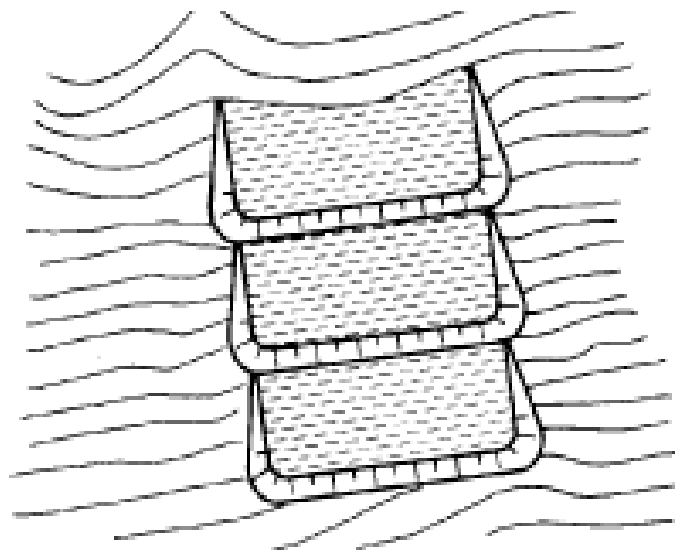

(b)

Figura 16. Represamento a meia encosta: (a) simples. (b) múltiplos (Vick 1983).

- Represamento em vale:

É uma combinação do represamento em bacia e a meia encosta. Este arranjo é aplicado quando o vale é muito largo, e existem nas margens áreas adequadas para a construção da barragem que não interferem com a drenagem natural. Para a construção deste tipo de represamento, deve-se desviar completamente o fluxo da zona de inundação em volta do represamento; o represamento fica na parede oposta ao canal de desvio. Na Figura 17 é apresentado esquematicamente este tipo de represamento, em uma etapa e em múltiplas etapas.

Se não ficar espaço suficiente quando é desviado o canal, é preciso realizar obras de terraplenagem na encosta, para garantir uma capacidade maior de barragem, ou realizar os alteamentos tipo anel, como é o caso da barragem de rejeitos de minério de cobre da empresa MINER S.A na Colômbia, apresentada na Figura 18.

O dique inicial deve apresentar alto fator de segurança, além de necessitar de obras de proteção no pé da barragem, já que as cheias do rio podem causar erosão e afetar a estabilidade da obra. 


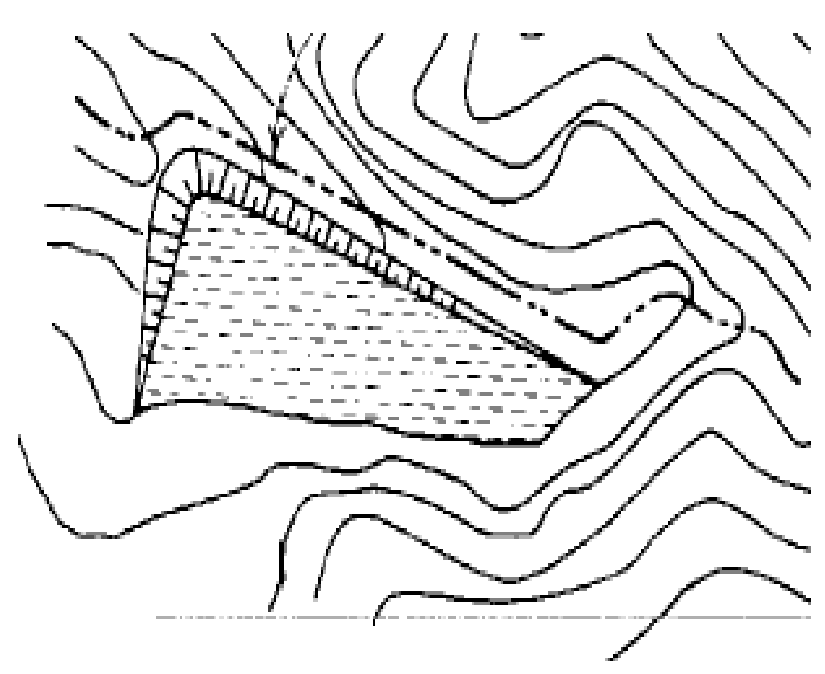

(a)

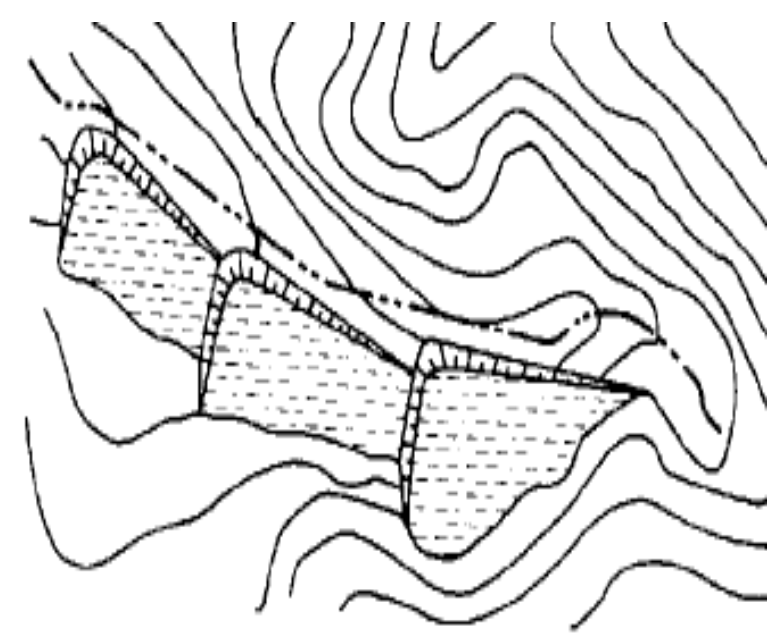

(b)

Figura 17. Represamento em vale: (a) simples. (b) múltiplos (Vick 1983).

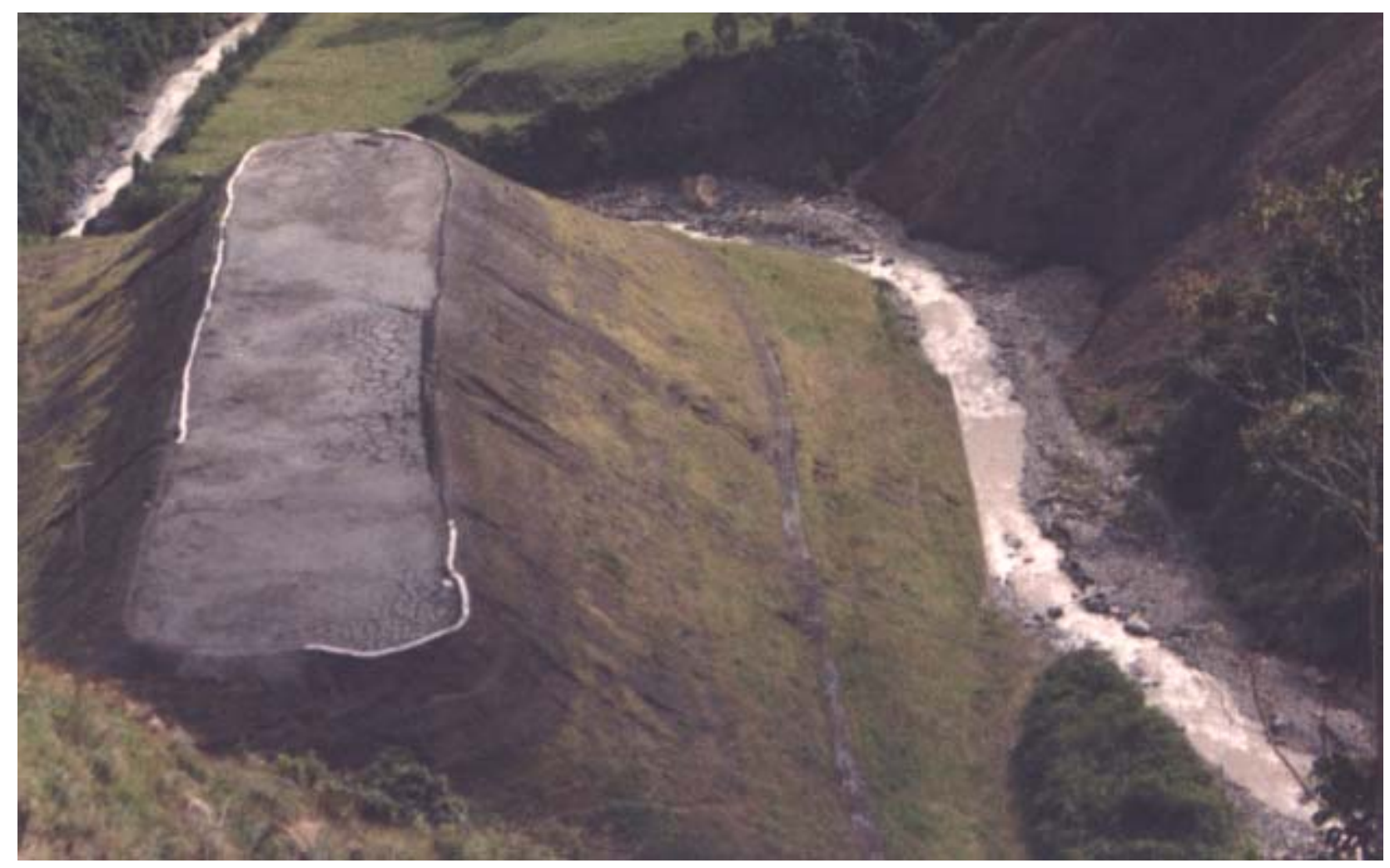

Figura 18. Represamento em vale: mineração de cobre, MINER S.A., Colômbia.

\subsection{Ritcey (1989).}

Os problemas ambientais, dependendo da mineralogia dos rejeitos, podem ser de anos (rejeitos com enxofre ou metais base) a centenas de anos (rejeitos de minérios de urânio). 
Ritcey (1989) classifica os sistemas de projeto e tratamento global em quatro classes principais:

- Seleção do local

- Preparação e projeto do local

- Preparação física dos rejeitos

- Preparação química dos rejeitos na usina de beneficiamento.

A seleção do local para as barragens de rejeitos de mineração engloba vários aspetos, incluindo a capacidade de armazenamento, a disponibilidade do local, hidrologia, custos iniciais, facilidade de operação, condições geológicos e geotécnicos. Na Tabela 6 são apresentados os critérios que, para Ritcey (1989), tem mais relevância na escolha dos locais.

\subsection{Robertson et al (1980-81-82-83-99 e 2004).}

A escolha do local tem uma influência significativa nos custos operacionais da mina. $\mathrm{Na}$ atualidade, as normas ambientais tornaram mais complexo o processo de seleção do local, não só para sua localização, mas também para quando forem terminadas as operações da jazida. Como critérios de seleção devem ser adicionados os aspetos de recuperação ambiental e fechamento da barragem de rejeito.

A quantidade de estudos necessários para a seleção do local depende da poluição potencial a curto ou longo prazo dos rejeitos e das regulamentações regionais específicas do local da mina.

A seleção do local representa um dos instrumentos que o engenheiro dispõe para assegurar a estabilidade a largo prazo da barragem de rejeitos, e deve ser sistemático, racional e objetivo, considerando todas as variáveis de tipo quantitativo e qualitativo para obter assim a melhor decisão. 
Tabela 6. Critérios para a escolha do local para implantação de uma barragem de rejeitos (Ritcey 1989).

\begin{tabular}{|c|c|c|}
\hline CRITÉRIO & \multicolumn{2}{|c|}{ OBSERVAÇÕES } \\
\hline 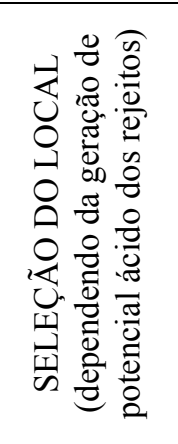 & $\begin{array}{l}\text {-Depois do fechamento da barragem, o fluxo de } \\
\text {-Fundações de baixa permeabilidade, para } \\
\text { subterrâneas. } \\
\text {-Se possível, presença ou proximidade de mine } \\
\text { águas subterrâneas, para haver precipitação } \\
\text { rejeitos. } \\
\text {-Evitar a possibilidade de geração de ácidos em } \\
\text {-Cuidado no projeto e construção de filtros (m } \\
\text { resultante da precipitação, por hidrólise, de sub } \\
\text {-Efeitos negativos por alterações na permea } \\
\text { algumas argilas pela percolação de águas com }\end{array}$ & $\begin{array}{l}\text { água sobre os rejeitos deve ser mínimo. } \\
\text { reduzir percolação e poluição das águas } \\
\text { rais calcários, com alto teor de carbonatos nas } \\
\text { de metais pesados das águas percoladas dos } \\
\text { rejeitos sólidos com pirita. } \\
\text { ateriais), evitando a possibilidade de obstrução } \\
\text { stâncias contaminantes. } \\
\text { bilidade, resistência e compressibilidade de } \\
\text { lementos quimicamente ativos. }\end{array}$ \\
\hline 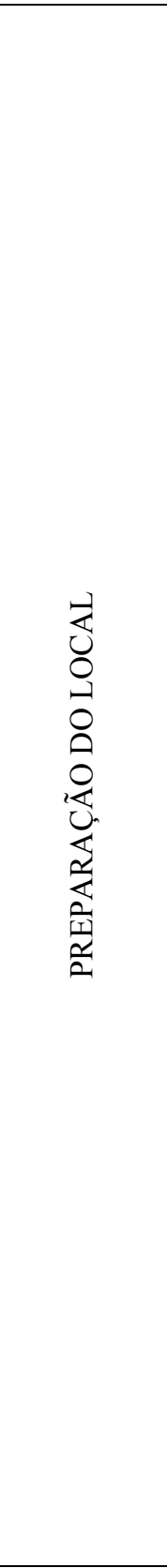 & 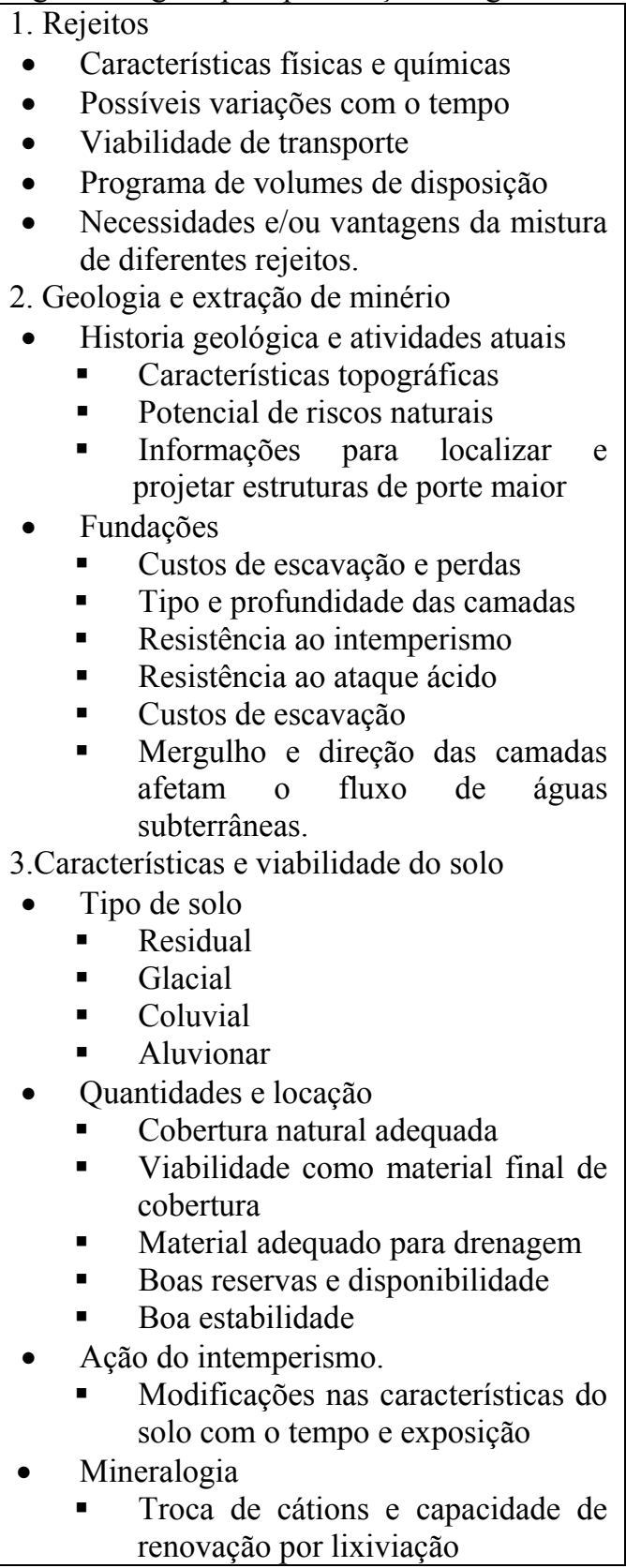 & 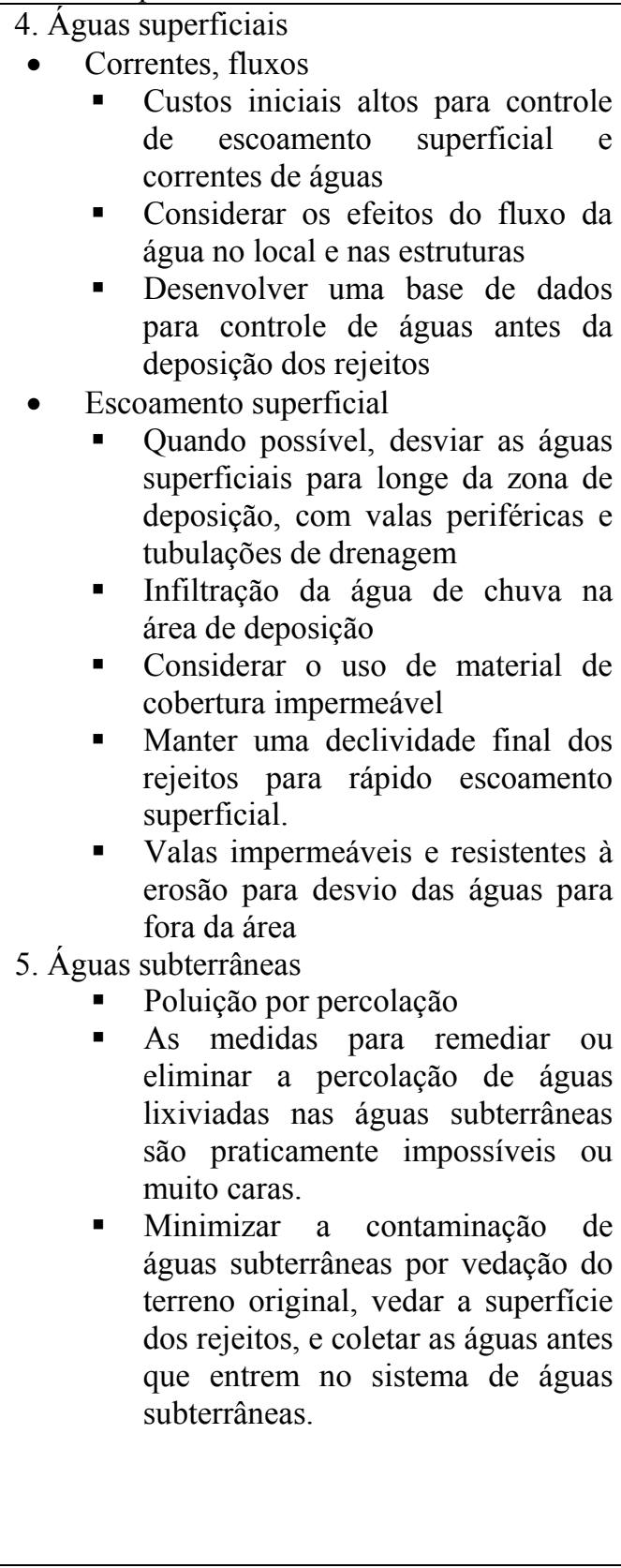 \\
\hline
\end{tabular}


Robertson divide o processo de seleção em duas fases, a Fase 1 de avaliação preliminar, e a Fase 2 de avaliação e investigação detalhada, cada uma com suas tarefas a serem executadas, conforme descrito a seguir.

Fase 1: Avaliação Preliminar

- Tarefa 1: Investigação regional

- Tarefa 2: Identificação de locais

- Tarefa 3: Análise de características desfavoráveis

- Tarefa 4: Investigação dos locais restantes

- Tarefa 5: Avaliação qualitativa e classificação

- Tarefa 6: Avaliação semi-quantitativa e classificação

- Tarefa 7: Análise de custos

- Tarefa 8: Seleção de alternativas para a fase de investigação detalhada.

A avaliação preliminar normalmente pode ser feita usando mapas topográficos em escala 1:25.000, podendo ser de muita ajuda a utilização de fotos aéreas da zona a ser estudada. As informações nesta fase incluem:

- Geologia.

- Posição da mina, facilidades e infra-estrutura.

- Qualidade e produção esperada (ton/dia) de rejeitos, além do tempo esperado de produção da lavra.

- Natureza e produção de outros tipos de rejeitos ou estéreis.

- Localização de outras minas na área.

- Regulamentações de tipo ambiental

- Hidrologia, hidrogeologia, geoquímica, clima, demografia, arqueologia, ecologia, usos do solo e potenciais zonas mineralizadas na área.

Fase 2: Avaliação e investigação detalhada

- Tarefa 9: Investigação detalhada dos locais selecionados

- Tarefa 10: Projeto conceitual dos locais

- Tarefa 11: Avaliação dos custos e riscos de poluição de cada um dois locais

- Tarefa 12: Classificação dos locais e seleção do principal local

- Tarefa 13: Preparação do relatório e documentação para o processo de revisão 
A avaliação da Fase 2 corresponde às características individuais dos locais selecionados na

Fase 1. Só se tratam os elementos individuais que se relacionam na avaliação preliminar.

A seguir estão detalhadas as tarefas correspondentes à Fase 1 do processo de seleção.

\section{Tarefa 1: Investigação Regional}

Requer-se para o estudo definir uma área entre 10 e 50 km, dependendo das especificações do projeto, e é necessário revisar sistematicamente os seguintes itens:

- As características topografias e sua influência na área de estudo

- Fatores climáticos

- Características ecológicas e uso do solo

- Condições hidrológicas

- Condições geológicas

- Possíveis zonas de mineralização (zonas com altas concentrações de minérios)

Na Tabela 7 são apresentados os critérios para excluir áreas na avaliação regional.

Tabela 7. Critérios para excluir áreas na investigação regional.

\begin{tabular}{|l|l|}
\hline Característica & Critério de exclusão \\
\hline Topografia & $\begin{array}{l}\text { Taludes íngremes, por exemplo, taludes com mais de 15\% de inclinação. } \\
\text { Áreas de difícil acesso. }\end{array}$ \\
\hline Clima & $\begin{array}{l}\text { Áreas com forte exposição aos fatores eólicos. } \\
\text { Áreas expostas a condições severas de intemperismo que podem influenciar as operações e } \\
\text { disposição. }\end{array}$ \\
\hline $\begin{array}{l}\text { Usos do solo e } \\
\text { ecologia }\end{array}$ & $\begin{array}{l}\text { Áreas de recreação ou lazer. } \\
\text { Áreas de habitat animal. } \\
\text { Áreas com ecossistemas sensíveis ou espécies em via de extinção. } \\
\text { Outras operações mineradoras na área. } \\
\text { Áreas de importância arqueológica. }\end{array}$ \\
\hline Áreas de uso intensivo, como campos petrolíferos.
\end{tabular}

\section{Tarefa 2: Identificação de locais}

Depois da investigação regional, todos os possíveis locais são identificados e as seguintes opções são consideradas: 
- Represamento em vale

- Represamento tipo anel (ambos, vale e anel, com material de empréstimo ou rejeitos, podem ser construídos pelo método da montante, jusante ou da linha de centro)

- Deposição em "pit” ou subterrânea.

- Opções especiais, i.e. deposição submarina, em cavas e outras que dependem das características da mina.

A capacidade de armazenamento do local é importante: é melhor um local com boa capacidade do que muitos locais com pequena capacidade de deposição. A avaliação, se possível, deve ser feita nas regiões de topografia natural ótima, i.e. áreas nas quais os trabalhos de desmonte e adequação são mínimos reduzindo assim os custos gerais do projeto.

Tarefa 3: Análise de características desfavoráveis

Uma característica desfavorável é qualquer elemento do local que pode produzir severos problemas na estrutura da barragem, ou nos elementos localizados na área do projeto. Essas características estão apresentadas na Tabela 8. A disponibilidade de fotos aéreas é de muita ajuda nesta tarefa e os locais com defeitos severos são eliminados das futuras considerações.

Tabela 8. Critérios de investigação para identificar características desfavoráveis do local.

\begin{tabular}{|c|c|}
\hline Critério & Característica desfavorável \\
\hline Visual & - $\quad$ Forte impacto visual \\
\hline Uso do solo/Ecológico & $\begin{array}{ll}\text { - } & \text { Espécies em perigo } \\
\text { - } & \text { Habitat crítico de fauna e peixes. } \\
\text { - } & \text { Ecossistemas únicos e sensíveis } \\
\text { - } & \text { Áreas importantes de recreação } \\
\text { - } & \text { Locais arqueológicos e históricos } \\
\text { - } & \text { Mineralização (fator econômico) } \\
\text { - } & \text { Poços de petróleo e linhas de tubulação. }\end{array}$ \\
\hline $\mathrm{Ar}$ & $\begin{array}{l}\text { - Pó/erosão, alta exposição ao vento } \\
\text { - Para rejeitos altamente perigosos (radioativos), proximidade de } \\
\text { população. }\end{array}$ \\
\hline Percolação & $\begin{array}{ll}\text { - } & \text { Fundações } \\
\text { - } & \text { Águas subterrâneas } \\
\text { - } & \text { Depósito aluvionar } \\
\end{array}$ \\
\hline Estabilidade & $\begin{array}{ll}\text { - } & \text { Topografia (taludes íngremes) } \\
\text { - } & \text { Falhas (ativas) } \\
\text { - } & \text { Área de drenagem muito grande } \\
\text { - } & \text { Condições das fundações pobres } \\
\end{array}$ \\
\hline Operacional & $\begin{array}{ll}\text { - } & \text { Capacidade (demasiado pequena) } \\
\text { - } & \text { Acesso (difícil) } \\
\text { - } & \text { Características técnicas (Não viáveis) } \\
\end{array}$ \\
\hline Custo & - $\quad$ Projeto não viável economicamente. \\
\hline
\end{tabular}




\section{Tarefa 4: Investigação dos locais restantes}

Depois da gradual eliminação de possíveis locais, a investigação dos locais restantes é feita com base nos seguintes itens:

- Volume, altura e área

- Área de represamento e especificações de volume

- Altura da barragem e volume requerido

- Volume da barragem selecionada

- Área da bacia

- Distância da mina

- Estimativa de acessos que terão que ser construídos.

- Modificação da elevação da planta de beneficiamento

- Proximidade e tamanho de assentamentos de população

- Tipo de solos e rochas das fundações e na área.

- Distância dos locais aos recursos hídricos

\section{Tarefa 5: Avaliação qualitativa e classificação}

Os fatores considerados para cada local estão apresentados na Tabela 9. Cada local é avaliado subjetivamente por essa lista de características, resultando em uma qualificação que vai de muito bom até muito ruim (Muito bom, bom, moderado, ruim, muito ruim), e de muito alto até muito baixo (Muito baixo, baixo, moderado, alto e muito alto). Situar um conceito "bom" indica uma condição boa, de boa qualidade, o impacto é baixo para essa característica do local. Um conceito muito "alto" indica um impacto alto.

\section{Tarefa 6: Avaliação semi-quantitativa e classificação}

Dois métodos de avaliação semiquantitativa são utilizados:

- Valoração do local baseada em aspetos visuais, uso do solo e ecologia, e fatores de operação

Às descrições qualitativas de muito bom, bom, moderado, ruim e muito ruim são dados valores numéricos de 1 até 5 , respectivamente; esses valores são baseados em uma escala arbitrária baseada em dados reais do local. Por exemplo, se a característica é área de alteração e os efeitos estão entre 0 ha e 500 ha, pode-se utilizar uma escala de valores associada a intervalos de área de alteração compatíveis com o conhecimento do local: para área de 
alteração entre 0 - 70 ha, valor 1; entre 70 - 130 ha, valor 2; entre 130 - 160 ha, valor 3; entre 160 - 200 ha, valor 4; e para área de 200 ha ou mais, valor 5.

Tabela 9. Avaliação qualitativa e classificação.

\begin{tabular}{|c|c|}
\hline Característica & Fator considerado \\
\hline Uso do solo/ecologia & $\begin{array}{l}\text { - Áreas de alteração = área total de represamento + área total de acessos } \\
\text { - Efeitos do detrimento a longo prazo em qualidade da vegetação, qualidade } \\
\text { do ar, qualidade humana. }\end{array}$ \\
\hline Poluição do ar & $\begin{array}{l}\text { - } \quad \text { Direção do vento } \\
\text { - Área de impacto } \\
\end{array}$ \\
\hline Poluição por percolação & $\begin{array}{ll}\text { - } & \text { Qualidade geológica natural } \\
\text { - } & \text { Qumadas apropriadas } \\
\text { - } & \text { Potencial de lixiviação } \\
\end{array}$ \\
\hline Poluição superficial & $\begin{array}{l}\text { - Condições da barragem e ruptura devido a: concentrações de fluxo, erosão. } \\
\text { - Ruptura das fundações por liquefação, por falhas ativas. }\end{array}$ \\
\hline Operacionais & $\begin{array}{l}\text { - } \quad \text { Capacidade de armazenamento } \\
\text { - } \quad \text { Distância da mina } \\
\text { - } \quad \text { Capilidade da construção, e materiais de recuperaçãao. } \\
\text { - } \quad \text { Exigências de conpansão } \\
\text { - } \quad \text { Dificuldades de operação (clima, acessos, etc.). } \\
\end{array}$ \\
\hline Sistemas de deposição & - Úmido, seco, semi-úmido. \\
\hline
\end{tabular}

Para as características de visibilidade, uso do solo/ecologia e fatores operacionais, usa-se esse tratamento, encontra-se a média dos valores e esses dados são colocados numa tabela resumo.

- Valoração do local baseado em fatores de risco e poluição

Os mecanismos de liberação de agentes poluentes podem-se classificar em três grandes categorias, resumidas na Tabela 10, que são os mecanismos de poluição do ar, percolação e lixiviação e transporte físico de poluentes.

O risco de poluição de cada um dos mecanismos anteriores depende de três variáveis:

- A probabilidade de ocorrência (L)

- A magnitude da poluição quando ocorre (M).

- Os fatores de mitigação reduzindo os potenciais impactos quando a poluição ocorre (Mit) 
Tabela 10. Mecanismos de poluição.

\begin{tabular}{|c|c|}
\hline Característica & Mecanismo de poluição \\
\hline Ar & $\begin{array}{l}\text { - Dispersão de partículas/erosão eólica } \\
\text { - Emissão de gases }\end{array}$ \\
\hline Percolação/lixiviação & $\begin{array}{ll}\text { - } & \text { Lixiviação devido a superfícies de infiltração e águas subterrâneas } \\
\text { - } & \text { Percolação }\end{array}$ \\
\hline $\begin{array}{l}\text { Transporte físico de } \\
\text { poluentes }\end{array}$ & $\begin{array}{l}\text { - } \\
\text { - } \quad \text { Concentramamão de fluxo de água (inundação/erosão profunda produzida pela } \\
\text { - } \quad \text { Euaa) } \\
\text { - } \quad \text { Ruptura da barragem } \\
\text { - } \quad \text { Overtopping” durante a operação da barragem } \\
\text { - Dispersão à população, animais e plantas. }\end{array}$ \\
\hline
\end{tabular}

Robertson (1980) determina o risco de poluição pela equação(1):

$$
\text { Risco de poluição }=\frac{L^{*} M}{M i t}
$$

Dá-se à probabilidade um valor de 1 a 5 , denotando 1 como muito baixa probabilidade e 5 como muito alta probabilidade. A magnitude também é quantificada de 1 a 5 , sendo 1 correspondente a magnitude muito pequena e 5 a uma muito grande; o mesmo se aplica à mitigação, 1 denotando mitigação não apreciável e 5 denotando alta mitigação.

\section{Tarefa 7: Análise de custos}

As análises de custos preliminares são realizadas para cada local separadamente, mas um orçamento exato e completo fica fora das expectativas da avaliação preliminar e é feita na Fase 2 do projeto. Os custos preliminares, avaliando alguns aspetos de importância quando for necessário, são de utilidade para decidir qual alternativa específica deve ser detalhada. Podem ser levados em conta para esta avaliação preliminar aspetos como: métodos prováveis de construção, deposição dos rejeitos (úmido, semi-úmido e seco), custos de mão de obra e equipamento. Porém, não deve ser um indicativo dos verdadeiros custos do projeto, pois a engenharia em detalhe da Fase 2 para os locais específicos é a mais importante.

Tarefa 8: Seleção de alternativas para a fase de investigação detalhada

As tabelas resumos das Tarefas 6 e 7 são utilizados para a seleção dos locais que passarão à Fase 2 do projeto.

Robertson e Shaw $(1999,2004)$ modificaram um pouco a valoração das propriedades de alguns elementos de seleção, além de mudar a escala numérica que Robertson $(1980,81,82$, 
83) aplicava para valorar as propriedades qualitativas de alguns aspetos (escala de valoração de 1 a 5$)$.

Para Robertson e Shaw $(1999,2004)$ a seleção dum local para armazenamento de rejeitos é uma das primeiras etapas que as empresas mineradoras deverão contemplar. Os locais de armazenamento de rejeitos não oferecem retorno econômico à companhia e requerem controle e conservação durante e depois da etapa de fechamento da mina. Existirão riscos em longo prazo de tipo ambiental e econômico associados a quaisquer estruturas de contenção de rejeitos de mineração. Maximizar segurança e minimizar os custos implica uma avaliação de alternativas de projeto do ponto de vista administrativo de perdas e benefícios. Para isto, é necessário desenvolver três etapas básicas:

- Identificar os impactos (benefícios e perdas) que deverão ser incluídos na avaliação.

- Quantificar os impactos (benefícios e perdas).

- Valorar os impactos, combinados ou acumulados, para cada opção e compará-los com outras opções; assim se desenvolve uma lista com valor, escala e peso, de preferências das opções.

Nestas três etapas, podem participar diferentes organizações (empresariais, sociais, agências ambientais) com pontos de vista diferentes, que se podem agrupar em uma escala de valores. A metodologia aplicada por Robertson e Shaw $(1999,2004)$ é chamada "Multiple Accounts Analysis" (MAA), que utiliza uma escala de valores de 1 a 9, onde 1 é muito desfavorável e 9 muito bom. A metodologia avalia e valora para cada local, uma estrutura principal e uma subestrutura de características que influenciam a seleção do mesmo. Depois da quantificação o maior valor, é então, a melhor opção. Esta metodologia não é alvo desta pesquisa, mas o interessante é a estrutura de características que apresenta, que consta da Tabela 11, trazendo assim mais elementos de avaliação na escolha do local: 
Tabela 11. Estrutura de avaliação MAA.

\begin{tabular}{|c|c|}
\hline Estrutura principal & Sub-estrutura \\
\hline Elementos Técnicos & $\begin{array}{ll}\text { - } & \text { Barragens } \\
\text { - } & \text { Mina } \\
\text { - } & \text { Desvios de rios } \\
\text { - } & \text { Tratamestimentos - Coberturas } \\
\text { - } & \text { Acessos } \\
\end{array}$ \\
\hline Ambiental & $\begin{array}{ll}\text { - } & \text { Clima } \\
\text { - } & \text { Qualidade do ar } \\
\text { - } & \text { Hidrologia e controle de águas } \\
\text { - } & \text { Ecologidade de água } \\
\text { - } & \text { Solos } \\
\text { - } & \text { Vegetação } \\
\text { - } & \text { Fauna } \\
\end{array}$ \\
\hline Econômicos & $\begin{array}{ll}\text { - } & \text { Custos de capital } \\
\text { - } & \text { Custos operacionais } \\
\text { - } & \text { Custos de fechamento ou abandono } \\
\text { - } & \text { Juros / impostos } \\
\text { - } & \text { Risco econômico } \\
\end{array}$ \\
\hline Sócio - econômico & $\begin{array}{ll}\text { - } & \text { Ingressos (diretos / indiretos) } \\
\text { - } & \text { Impostos (diretos / indiretos) } \\
\text { - } & \text { Gaston governamentais } \\
\text { - } & \text { Análise de mercado de trabalho } \\
\text { - } & \text { População } \\
\text { - } & \text { Aldeia, vila, cidade. } \\
\text { - } & \text { Saúde e segurança } \\
\text { - } & \text { Recurropos hídricos navegáveis } \\
\text { - } & \text { Transporte e tráfego } \\
\text { - } & \text { Turismo, recreação } \\
\text { - } & \text { Estética } \\
\text { - } & \text { Arqueologia, locais tradicionais. } \\
\end{array}$ \\
\hline
\end{tabular}

\subsection{Zuquette e Gandolfi (2004), Liporaci e Zuquette (1995).}

Baseado em mapas geotécnicos, os autores apresentam atributos mais específicos para a disposição de resíduos, sendo o primeiro trabalho direcionado à de seleção de locais para aterros sanitários e o segundo para a disposição de rejeitos de mineração. Os atributos definidos na escolha de locais para aterros sanitários são uma excelente base para a seleção de locais de rejeitos de mineração. Mesmo que os resíduos (lixo ou rejeito) sejam diferentes, as condições gerais para a seleção dos locais apresentam características que servem na escolha do local para barragens de rejeitos.

Zuquette e Gandolfi (2004) apresentam um esquema dos aspetos técnicos que relacionam o aterro sanitário com o meio ambiente que é facilmente aplicável a barragens de rejeitos, já que 
os rejeitos, como os resíduos, constituem uma fonte de poluição que contamina diretamente o meio físico (materiais inconsolidados, águas sub e superficiais e substrato rochoso), e que a contaminação varia não só em função da quantidade do rejeito ou lixo, mas principalmente quanto ao tipo. Na Figura 19 se apresenta o esquema voltado a barragens de rejeitos

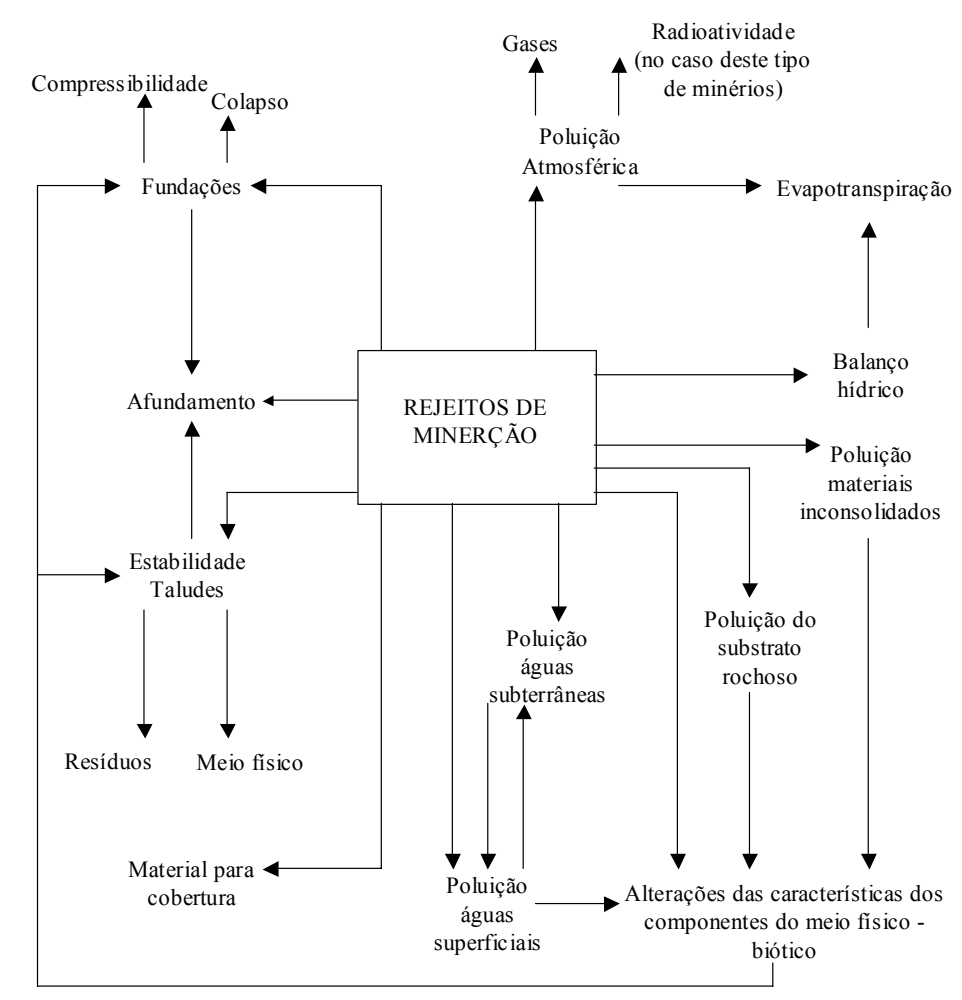

Figura 19. Aspectos técnicos que relacionam a barragem de rejeito e o meio ambiente. (Fonte:ZuquetteGandolfi 2004, Modificado).

Os autores propõem, com base nas relações da Figura 19, uma lista de atributos que devem ser considerados nos procedimentos de seleção de locais para disposição de resíduos. Estes atributos são apresentados em nível geral, e se definem classes associadas a intervalos quanto ao grau de restrições de meio físico, como se observa na Tabela 12. 
Tabela 12. Atributos para definição e delimitação de unidades do meio físico visando à seleção de áreas para disposição de resíduos.

\begin{tabular}{|c|c|c|c|c|c|c|}
\hline \multirow{2}{*}{ 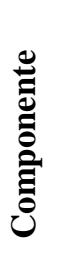 } & \multirow[b]{2}{*}{ ATRIBUTO } & \multirow[b]{2}{*}{ PARÂMETRO } & \multicolumn{4}{|l|}{ CLASSES } \\
\hline & & & Favorável & Moderada & Severa & Restritiva \\
\hline \multirow{2}{*}{ 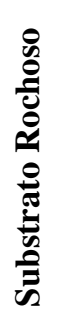 } & & $\begin{array}{l}\text {-Resistência } \\
\text { Mecânica } \\
\text {-Mineralogia } \\
\text {-Cimentação } \\
\text {-Arranjo }\end{array}$ & $\begin{array}{l}\text { Gnaisses, } \\
\text { migmatitos, } \\
\text { siltitos e } \\
\text { argilitos }\end{array}$ & Granitos & Conglomerados & Arenitos \\
\hline & Profundidade (m) & & $>15$ & $5-10$ & $<5$ & $<3$ \\
\hline \multirow{15}{*}{ 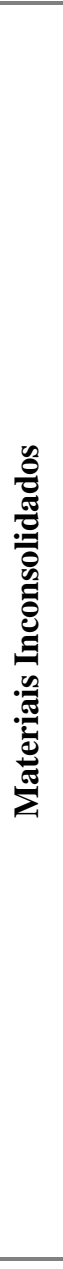 } & $\begin{array}{l}\text { Descontinuidade } \\
\text { (juntas } / \mathrm{m}^{3} \text { ) }\end{array}$ & $\begin{array}{l}\text { Contador } \\
\text { volumétrico de } \\
\text { juntas (JV) }\end{array}$ & $<3$ & $3-30$ & $>30$ & $>60$ \\
\hline & $\begin{array}{l}\text { Classificação } \\
\text { textural }\end{array}$ & ASTM (1994) & $\begin{array}{l}\text { Areia } \\
\text { argilosa }\end{array}$ & $\begin{array}{l}\text { Argila } \\
\text { arenosa }\end{array}$ & Arenosa & Muito arenosa \\
\hline & Variação vertical & & Heterogêneo & Heterogêneo & Homogêneo & Homogêneo \\
\hline & Mineralogia & $\begin{array}{l}\text { Argilominerais. } \\
\text { Minerais inertes }\end{array}$ & $\begin{array}{l}\text { Argilomine } \\
\text { rais } 2 X 1\end{array}$ & $\begin{array}{l}\text { Argilominer } \\
\text { ais } 1 \mathrm{X} 1\end{array}$ & $\begin{array}{l}\text { Minerais } \\
\text { inertes }\end{array}$ & $\begin{array}{l}\text { Minerais } \\
\text { inertes }\end{array}$ \\
\hline & \multirow{3}{*}{ Matacões } & $\begin{array}{l}\text { Tamanho (maior } \\
\text { dimensão) }\end{array}$ & Não & $<1 \mathrm{~m}$ & $1 \mathrm{a} 2 \mathrm{~m}$ & $>2 \mathrm{~m}$ \\
\hline & & Freqüência & & $2 / 1000 \mathrm{~m}^{3}$ & 2 a $5 / 1000 m^{3}$ & $>5 / 1000 \mathrm{~m}^{3}$ \\
\hline & & Profundidade & & $>2 \mathrm{~m}$ & $<2 \mathrm{~m}$ & $<0.5 \mathrm{~m}$ \\
\hline & $\mathrm{pH} / \Delta \mathrm{pH}(*)$ & & $>4 /$ negativo & $>4 /$ negativo & $>5 /$ negativo & $<5 /$ positivo \\
\hline & $\begin{array}{l}\text { Salinidade } \\
(\mathrm{mhos} / \mathrm{cm})\end{array}$ & $\begin{array}{l}\text { Condutividade } \\
\text { elétrica }\end{array}$ & $<16$ & $<16$ & $>16$ & Alto \\
\hline & $\begin{array}{l}\text { Capacidade de } \\
\text { Troca Catiônica } \\
\text { (C.T.C) } \\
\text { (meq } / 100 \mathrm{~g})\end{array}$ & & $>15$ & $5-15$ & $<5$ & $<2$ \\
\hline & $\begin{array}{l}\text { Camada } \\
\text { compressível }\end{array}$ & $\begin{array}{l}\text { Espessura } \\
\text { profundidade }\end{array}$ & Não & Não & $\begin{array}{l}\text { Camada } \\
\text { superficial }\end{array}$ & $\begin{array}{l}\text { Camada } \\
\text { superficial }\end{array}$ \\
\hline & $\begin{array}{l}\text { Material } \\
\text { colapsível }\end{array}$ & $\begin{array}{l}\text { Espessura } \\
\text { profundidade }\end{array}$ & Não & $\begin{array}{l}\text { Camada } \\
\text { superficial } \\
(2 \mathrm{~m})\end{array}$ & $\begin{array}{l}\text { Camada } \\
\text { superficial } \\
(4 \mathrm{~m})\end{array}$ & $\begin{array}{l}\text { Camada } \\
\text { superficial } \\
(6 \mathrm{~m})\end{array}$ \\
\hline & $\begin{array}{ll}\text { Índice } & \mathrm{de} \\
\text { erodibilidade } & \end{array}$ & & Baixo & Baixo & Alto & Muito alto \\
\hline & $\begin{array}{ll}\text { Fator } & \mathrm{de} \\
\text { retardamento } & \end{array}$ & & Alto & $\begin{array}{l}\text { Intermediári } \\
\mathrm{o}\end{array}$ & Baixo & Baixo \\
\hline & $\begin{array}{l}\text { Características de } \\
\text { compactação }\end{array}$ & Proctor normal & adequada & adequada & inadequada & inadequada \\
\hline \multirow{4}{*}{ 莫 } & \multirow{2}{*}{$\begin{array}{l}\text { Profundidade de } \\
\text { zona saturada (m) }\end{array}$} & Metros & $>10$ & $>6$ & $<4$ & $<2$ \\
\hline & & Variações anuais & $<1$ & $<1$ & 1 a 2 & $>1$ \\
\hline & $\begin{array}{l}\text { Direção do fluxo } \\
\text { saturado }\end{array}$ & $\begin{array}{l}\text { Numero } \\
\text { direções }\end{array}$ & 1 & 1 & 2 ou 3 & $>3$ \\
\hline & Fluxo superficial & & laminar & laminar & $\begin{array}{l}\text { Laminar/conce } \\
\text { ntrado }\end{array}$ & Concentrado \\
\hline
\end{tabular}




\begin{tabular}{|c|c|c|c|c|c|c|}
\hline & $\begin{array}{l}\text { Condutividade } \\
\text { hidráulica }(\mathrm{cm} / \mathrm{s})\end{array}$ & & $<10^{-4}$ & $10^{-3}-10^{-4}$ & $>10^{-3}$ & $\begin{array}{l}\text { Muito alta } \\
\left(>10^{-2}\right)\end{array}$ \\
\hline & Áreas de recarga & & Não & Não & Não & Ocorre \\
\hline & $\begin{array}{ll}\text { Distancia } & \text { da } \\
\text { nascente }(m)\end{array}$ & & $>500$ & $400-500$ & $400-300$ & $<300$ \\
\hline & Drenagem & Carta especifica & Adequada & Adequada & inadequada & inadequada \\
\hline \multirow{9}{*}{ 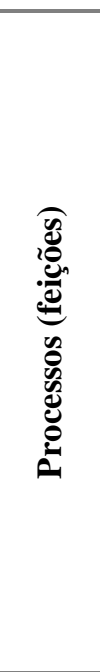 } & \multirow{2}{*}{ Erosão } & Freqüência & Não & Não & Susceptibilidade & $\begin{array}{l}\text { Alta } \\
\text { susceptibilidade }\end{array}$ \\
\hline & & Intensidade & & & $1 / \mathrm{km}^{2}$ & $>5 / \mathrm{km}^{2}$ \\
\hline & \multirow{2}{*}{$\begin{array}{l}\text { Movimentos de } \\
\text { massa } \\
\text { gravitacionais }\end{array}$} & Freqüência & Não & Não & $\begin{array}{l}\text { Susceptibilidad } \\
\text { e. }\end{array}$ & Ocorre \\
\hline & & Intensidade & & & $<3 / \mathrm{km}^{2}$ & $>3 / \mathrm{km}^{2}$ \\
\hline & \multirow{2}{*}{ Subsidências } & Freqüência & Não & Não & Não & Ocorre \\
\hline & & Intensidade & & & & $1 / \mathrm{km}^{2}$ \\
\hline & \multirow{2}{*}{$\begin{array}{l}\text { Processo } \\
\text { cársticos }\end{array}$} & Freqüência & Não & Não & Não & Ocorre \\
\hline & & Intensidade & & & & $1 / \mathrm{km}^{2}$ \\
\hline & $\begin{array}{ll}\begin{array}{l}\text { Zonas } \\
\text { inundação }\end{array} & \text { de }\end{array}$ & $\begin{array}{l}\text { Freqüência } \\
\text { (intensidade área } \\
\text { afetada) }\end{array}$ & Não & Não & $\begin{array}{l}\text { Período de } \\
\text { retorno entre } \\
20 \text { e } 50 \text { anos }\end{array}$ & $\begin{array}{l}\text { Período } \text { de } \\
\text { retorno }<20 \\
\text { anos }\end{array}$ \\
\hline \multirow{4}{*}{ 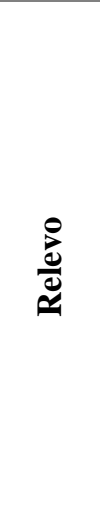 } & Formas de relevo & & $\begin{array}{l}\text { Encostas } \\
\text { planas } \\
\text { (inclinação } \\
<15^{\circ} \text { ) }\end{array}$ & & $\begin{array}{l}\text { Encostas } \\
\text { íngremes } \\
\text { (inclinações } 45 \\
\text { a } 60^{\circ} \text { ). Zonas } \\
\text { marginais de } \\
\text { inundação }\end{array}$ & $\begin{array}{l}\text { Zonas } \\
\text { marginais de } \\
\text { inundação }\end{array}$ \\
\hline & $\begin{array}{lr}\text { Distância } & \text { do } \\
\text { limite } & \text { entre } \\
\text { bacias } & \\
\text { hidrográficas } & \\
\end{array}$ & & $>200 \mathrm{~m}$ & $\begin{array}{l}\text { Entre } 200 \mathrm{~m} \\
\text { e } 100 \mathrm{~m}\end{array}$ & $<100 \mathrm{~m}$ & Coincidente \\
\hline & Zonas úmidas & & Não & Não & Não & Ocorre \\
\hline & Declividade (\%) & & $2-5$ & $>5,<2 / 5$ & $>15$ & $>20$ \\
\hline \multirow{3}{*}{ 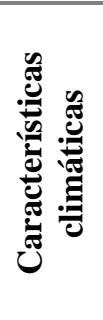 } & Evapotranspiração & Total anual & $\begin{array}{l}\text { Alto } \\
(<1000 \mathrm{~mm})\end{array}$ & $\begin{array}{l}\text { Intermediário } \\
(800 \quad- \\
1000 \mathrm{~mm})\end{array}$ & $\begin{array}{l}\text { Baixo (800 - } \\
600 \mathrm{~mm})\end{array}$ & $\begin{array}{l}\text { Muito baixo } \\
(<600 \mathrm{~mm})\end{array}$ \\
\hline & Direção do vento & & & & & $\begin{array}{l}\text { Em direção à } \\
\text { zona urbana }\end{array}$ \\
\hline & $\begin{array}{l}\text { Pluviosidade } \\
(\mathrm{mm})\end{array}$ & Total anual & & & $>200 \mathrm{~mm} / \mathrm{ano}$ & $\begin{array}{l}>3000 \\
\mathrm{~mm} / \mathrm{ano}\end{array}$ \\
\hline
\end{tabular}

$* \Delta \mathrm{pH}=\mathrm{pH} \mathrm{KCl}-\mathrm{pH} \mathrm{H}_{2} \mathrm{O}$

\subsection{Tabela Resumo.}

Com os fatores que influenciam a seleção de locais para barragens de rejeitos anteriormente descritos, formulou-se o quadro comparativo da Tabela 13. O objetivo da tabela resumo é determinar os parâmetros adotados para a análise e avaliação das diferentes alternativas na seleção dos locais por diversos autores, com base na sua experiência profissional. 
Tabela 13. Tabela Resumo por autor.

\begin{tabular}{|c|c|c|c|c|c|c|}
\hline \multicolumn{2}{|c|}{$\begin{array}{l}\text { CRITÉRIOS E } \\
\text { INDICADORES } \\
\end{array}$} & $\begin{array}{c}\text { BRAWNER E } \\
\text { CAMPBELL (1973) } \\
\end{array}$ & VICK $(1981$ - 1983) & RITCEY G,M, (1989) & MacG ROBERTSON (1980 - 2004) & $\begin{array}{l}\text { LIPORACI - ZUQUETTE (1995) } \\
\text { ZUQUETTE GANDOLFI (2004) } \\
\end{array}$ \\
\hline \multicolumn{2}{|c|}{$\begin{array}{l}\text { ASPETOS } \\
\text { ECONÔMICOS }\end{array}$} & & -Custos operacionais & -Custos iniciais & $\begin{array}{l}\text { - Custos de capital } \\
\text { - Custos operacionais } \\
\text { - Custos de fechamento ou abandono } \\
\text {-Juros / impostos } \\
\text { - Risco econômico }\end{array}$ & \\
\hline \multirow{3}{*}{ 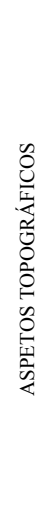 } & 噼 & $\begin{array}{l}\text { - Estudo de } \\
\text { mapas } \\
\text { topográficos. }\end{array}$ & & Características topográficas. & $\begin{array}{l}\text { CRITÉRIO DE EXCLUSÃO: } \\
\text {-Taludes íngremes, por exemplo, taludes com mais de } 15 \% \text { de inclinação. }\end{array}$ & $\begin{array}{l}\text {-Formas de relevo } \\
\text { - Distância do limite entre bacias } \\
\text { hidrográficas } \\
\text { - Zonas úmidas } \\
\text { - Declividade (\%) }\end{array}$ \\
\hline & 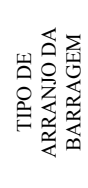 & & $\begin{array}{l}\text { - Represamento tipo anel } \\
\text {-Represamento numa bacia } \\
\text {-Represamento a meia } \\
\text { encosta } \\
\text {-Represamento em vale }\end{array}$ & & $\begin{array}{l}\text { - Represamento em vale } \\
\text {-Represamento tipo anel (ambos, vale e anel, com material de empréstimo ou } \\
\text { rejeitos, podem ser pelo método da montante, jusante ou da linha de centro) } \\
\text {-Deposição em "pit" ou subterrânea. } \\
\text {-Op̧cóes especiais, i.e. deposição submarina, em cavas e outras que dependem } \\
\text { das características da mina }\end{array}$ & \\
\hline & $\sum_{\bar{L}}^{\overleftarrow{1}}$ & & $\begin{array}{l}\text { - Local e elevação relativa } \\
\text { da usina de beneficiamento }\end{array}$ & & $\begin{array}{l}\text {-Posição da mina, facilidades e infra-estrutura. } \\
\text { - Localização de outras minas na área. } \\
\text { - Distância da usina. }\end{array}$ & \\
\hline \multirow{2}{*}{ 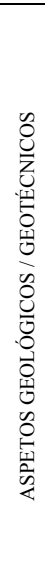 } & & $\begin{array}{l}\text { - Comportamento } \\
\text { geral dos solos, } \\
\text { fundações e } \\
\text { rochas. } \\
\text { - Localização } \\
\text { quantidades e } \\
\text { tipo de materiais } \\
\text { de empréstimo. }\end{array}$ & $\begin{array}{l}\text { - Viabilidade de materiais } \\
\text { de empréstimo, tipos e } \\
\text { quantidades, teor de } \\
\text { umidade. } \\
\text { - Perdas por percolação, } \\
\text { permeabilidades. } \\
\text { - Estabilidades nas } \\
\text { fundações } \\
\text { - Falhas, sismicidade, } \\
\text { estruturas de retenção. }\end{array}$ & $\begin{array}{l}\text { - Geologia e extração de minério } \\
\text { - Fundações: } \\
\text {-Custos de escavação e perdas } \\
\text {-Benefícios da resistência à erosão na } \\
\text { construção } \\
\text {-Local, tipo e profundidade das camadas. } \\
\text {-Resistência ao intermpersimo. } \\
\text {-Resistência do ataque ácido. } \\
\text {-Custos de escavação } \\
\text {-Mergulho e direção da camada, afeita o } \\
\text { local e o fluxo de águas subterrâneas. } \\
\text { - Tipo de solo (residual, glacial, coluvial, } \\
\text { aluvionar), quantidades e locação. } \\
\text { - Mineralogia. }\end{array}$ & $\begin{array}{l}\text { CRITERIOS DE EXCLUSAO: } \\
\text { - Falhas ativas. } \\
\text { - Áreas de deposito aluvial ou eólico, i.e. áreas altamente permeáveis e } \\
\text { erodíveis. } \\
\text { - Áreas com problemas nas fundações (por exemplo, áreas cársticas } \\
\text { dolomíticas). } \\
\text { - Delinear zonas de mineralização conhecida } \\
\text { - Tipo de solos e rochas das fundações e na área } \\
\text { - Percolação. }\end{array}$ & $\begin{array}{l}\text {-Litologia: Resistência mecânica, } \\
\text { mineralogia, cimentação, arranjo, } \\
\text { profundidade } \\
\text { - Materiais inconsolidados: } \\
\text { Descontinuidades, classificacãa textural, } \\
\text { variação vertical, matações, pH, } \\
\text { salinidade, cappacidadede troca catiônica, } \\
\text { camada compressível, material } \\
\text { colapsivel, indice de erodibilidade, fator } \\
\text { de retardamento, características de } \\
\text { compactação. }\end{array}$ \\
\hline & 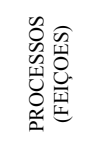 & & & $\begin{array}{l}\text { - Potencial de riscos naturais } \\
\text {-. Ação do intemperismo. }\end{array}$ & $\begin{array}{l}\text { - Processos cársticos } \\
\text { - Erosão por percolação. }\end{array}$ & $\begin{array}{l}\text { - Erosão } \\
\text { - Movimentos de massa gravitacionais } \\
\text { - Subsidências. } \\
\text { - Processos cársticos. } \\
\text { - Zonas de inundação. }\end{array}$ \\
\hline
\end{tabular}




\begin{tabular}{|c|c|c|c|c|c|c|}
\hline \multicolumn{2}{|c|}{$\begin{array}{l}\text { CRITÉRIOS E } \\
\text { INDICADORES } \\
\end{array}$} & $\begin{array}{c}\text { BRAWNER E } \\
\text { CAMPBELL (1973) } \\
\end{array}$ & VICK (1981 - 1983) & RITCEY G,M, (1989) & MacG ROBERTSON (1980 - 2004) & $\begin{array}{l}\text { LIPORACI - ZUQUETTE (1995) } \\
\text { ZUQUETTE GANDOLFI (2004) }\end{array}$ \\
\hline \multicolumn{2}{|c|}{ 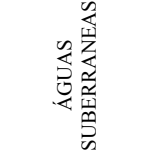 } & $\begin{array}{l}\text { Condições das } \\
\text { águas } \\
\text { subterrâneas, } \\
\text { percolação. }\end{array}$ & $\begin{array}{l}\text { - Vazão e direção de } \\
\text { percolação } \\
\text {-Potencial de contaminação. }\end{array}$ & $\begin{array}{l}\text { - Poluição por percolação: } \\
\text {-Remediar ou eliminar a percolação de águas } \\
\text { lixiviadas. } \\
\text {-Minimizar a contaminação }\end{array}$ & $\begin{array}{l}\text { - Áreas de descarga de águas subterrâneas (possibilidade de lixiviação). } \\
\text { - Poluição por percolação: qualidade geológica natural, camadas apropriadas, } \\
\text { qualidade geoquímica, potencial de lixiviação devido a superficies de infiltração. }\end{array}$ & \\
\hline \multicolumn{2}{|c|}{ 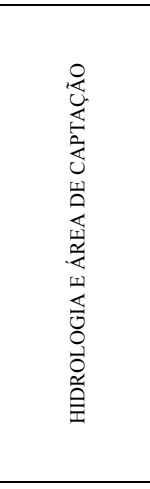 } & & $\begin{array}{l}\text { - Tempo de acumulação de } \\
\text { água suficiente para } \\
\text { permitir a sedimentação. } \\
\text { - Exigênciass de manejo de } \\
\text { inundações }\end{array}$ & $\begin{array}{l}\text { - Correntes, fluxos: } \\
\text {-controle de escoamentos superficiais e } \\
\text { correntes de águas. } \\
\text {-efeitos de fluxo da água no local e nas } \\
\text { estruturas } \\
\quad \text {-controle de águas antes da deposição dos } \\
\text { rejeitos. } \\
\text { - Escoamento superficial: } \\
\text {-desviar as águas da superfície longe da } \\
\text { zona de deposição (valas periféricas, } \\
\text { tubulações de drenagem). } \\
\text { - Infittracãao da água de chuva na área de } \\
\text { deposicãa: } \\
\text {-Uso de material de cobertura } \\
\text { impermeável. } \\
\text {-Manter um nivelamento final dos rejeitos } \\
\text {-Valas impermeáveis e resistentes. }\end{array}$ & $\begin{array}{l}\text { CRITÉRIO DE EXCLUSÃO: } \\
\text { - Excluir áreas de bacias hidrográficas grandes, exceto, se é possível desviar as } \\
\text { correntes. }\end{array}$ & $\begin{array}{l}\text { - Profundidade de zona saturada. } \\
\text { - Direção do fluxo saturado. } \\
\text { - Fluxo superficial. } \\
\text { - Condutividade hidráulica. } \\
\text { - Áreas de recarga. } \\
\text { - Distância da nascente. } \\
\text { - Drenagem. }\end{array}$ \\
\hline \multicolumn{2}{|c|}{$\begin{array}{l}\text { ASPETOS } \\
\text { CLIMÁTICOS }\end{array}$} & $\begin{array}{l}\text { - Analise } \\
\text { climatológica e } \\
\text { registro de } \\
\text { escoamento } \\
\text { superficial }\end{array}$ & $\begin{array}{l}\text { - Taxa anual de precipitação } \\
\text { e evaporação. }\end{array}$ & & $\begin{array}{l}\text { CRITÉRIOS DE EXCLUSÃO: } \\
\text { - Áreas com forte exposição aos fatores eólicos. } \\
\text { - Áreas expostas a condiçôes severas de intemperismo. } \\
\text { - Ar: Pó/rorosão, alta exposição ao vento (rejeitos radioativos), proximidade de } \\
\text { população. } \\
\text { MECANISMO DE POLUIĈ̃̃̃: } \\
\text { Direção do vento, dispersão de partículas / erosão eólica, }\end{array}$ & $\begin{array}{l}\text { - Evapotranspiração, direção do vento, } \\
\text { Pluviosidade }\end{array}$ \\
\hline \multirow{2}{*}{ 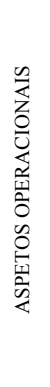 } & 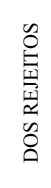 & $\begin{array}{l}\text { - Quantidade de } \\
\text { rejeitos } \\
\text { produzidos } \\
\text { - Velocidade de } \\
\text { deposição. }\end{array}$ & & $\begin{array}{l}\text { - Características físicas e químicas } \\
\text { - Possíveis variações com o tempo } \\
\text { - Viabilidade de transporte } \\
\text { - Programa de volumes de disposição } \\
\text { - Necessidades e/ou vantagens da mistura de } \\
\text { diferentes matérias de rejeitos. }\end{array}$ & $\begin{array}{l}\text { - Qualidade e produção esperada (ton/dia) de rejeitos, além do tempo esperado de } \\
\text { produção da lavra. } \\
\text { - Natureza e produção de outros tipos de rejeitos ou estéreis. }\end{array}$ & \\
\hline & $\begin{array}{l}\overrightarrow{3} \\
0 \\
0 \\
0 \\
0\end{array}$ & $\begin{array}{l}\text {-Volumes de } \\
\text { armazenamento }\end{array}$ & & - Capacidade de armazenamento & $\begin{array}{l}\text { - Acesso (difícil) } \\
\text { - Características técnicas (Não viáveis) } \\
\text {-Capacidade de armazenamento } \\
\text { - Distância da mina } \\
\text { - Viabilidade da construção, e materiais de recuperação. } \\
\text { - Capacidade de expansão } \\
\text { - Exigências de controle de superfícies de drenagem. }\end{array}$ & \\
\hline
\end{tabular}




\begin{tabular}{|c|c|c|c|c|c|}
\hline $\begin{array}{l}\text { CRITÉRIOS E } \\
\text { INDICADORES } \\
\end{array}$ & $\begin{array}{c}\text { BRAWNER E } \\
\text { CAMPBELL (1973) } \\
\end{array}$ & VICK (1981 - 1983) & RITCEY G,M, (1989) & MacG ROBERTSON (1980 - 2004) & $\begin{array}{l}\text { LIPORACI - ZUQUETTE (1995) } \\
\text { ZUQUETTE GANDOLFI (2004) }\end{array}$ \\
\hline 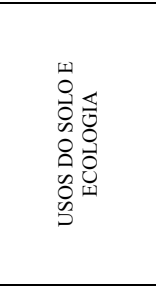 & & & & $\begin{array}{l}\text { - Áreas de recreação ou lazer. } \\
\text { - Áreas de habitat animal. } \\
\text { - Propriedade da terra. } \\
\text { - Áreas com ecossistemas sensíveis } \\
\text { - Outras operações mineiras na área. } \\
\text { - Áreas de importância arqueológica. } \\
\text { - Áreas de uso intensivo. } \\
\text {-Áreas de alteracãão = área total de represamento + área total de acessos } \\
\text { - Efeitos do detrimento em largo prazo em qualidade da vegetação, qualidade do } \\
\text { ar, qualidade humana. }\end{array}$ & \\
\hline 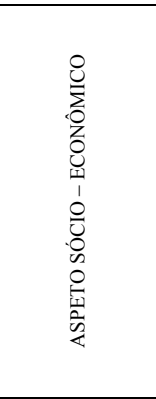 & & & & $\begin{array}{l}\text { - Ingressos (diretos / indiretos) } \\
\text { - Impostos (diretos / indiretos) } \\
\text {-Desenvolvimento governamental regional } \\
\text { - Gastos governamentais } \\
\text {-Análise de mercado de trabalho } \\
\text { - População } \\
\text { - Aldeia, vila, cidade. } \\
\text { - Saúde e seguridade } \\
\text { - Propriedade da terra } \\
\text { - Recursos hídricos navegáveis } \\
\text { - Transporte e tráfego } \\
\text { - Turismo, recreação. } \\
\text { - Estética } \\
\text {-Arqueologia, locais tradicionais. }\end{array}$ & \\
\hline
\end{tabular}




\section{MÉTODO DE ANÁLISE HIERÁRQUICA.}

Inicialmente são feitas algumas considerações sobre os métodos de tomada de decisões e a seguir apresenta-se o método de análise hierárquica.

\subsection{Métodos multicriteriais de auxílio à tomada de decisões.}

A seleção de uma área para a construção de uma barragem de rejeitos é um processo de avaliação que abrange uma grande quantidade de variáveis (ver Tabela 13), necessitando de um método que estruture o problema e facilite sua visualização. A utilização de um método multicriterial de auxílio à tomada de decisão se justifica pelo fato de considerar critérios quantitativos e qualitativos simultaneamente na análise e ao mesmo tempo incorporar a experiência e a preferência dos tomadores de decisão. Assim, a escolha será bastante consistente e confiável (Lisboa 2002).

Clemen (1991) considera que o propósito da análise de decisão é ajudar o tomador de decisões a pensar sistematicamente a respeito de grandes problemas e melhorar a qualidade das decisões, sendo que há quatro fontes de fatores que dificultam a tomada de decisão:

- Complexidade do problema

- Incertezas que envolvem as circunstâncias

- Tratar vários objetivos num mesmo problema

- Uma ou várias perspectivas que conduzam a conclusões adversas (o resultado não é sistematicamente o mesmo)

Para Baasch (1995), nos processos multicriteriais existe um tomador de decisões (ou vários), que toma a decisão e opera segundo um esquema seqüencial de fases, que não é estático e nem linear, que pressupõe realimentações, revisões e formulações no decorrer do processo. As etapas básicas do processo de tomada de decisões seriam:

- Definição das ações potenciais ou desejáveis a serem analisadas

- Formulação dos critérios de análise

- Avaliação das ações com base em cada critério

- Agregação final. 
Para Pomeranz (1992), um método multicriterial é definido pelas seguintes etapas:

- Formulação de alternativas

- Escolha de critérios e indicadores

- Avaliação das alternativas segundo os critérios e indicadores escolhidos (avaliação parcial)

- Agregação das avaliações parciais.

Através da avaliação parcial aprecia-se o grau de alcance dos objetivos do projeto expressos pelos critérios.

Carvalho (1996) propõe que um problema de decisão se apóie num processo lógico de auxílio à decisão, construído no âmbito da teoria da análise de decisão, e das várias pautas envolvidas na estruturação do problema:

- A construção do modelo de decisão compreende a identificação das variáveis intervenientes no problema, a caracterização das relações lógicas entre essas variáveis e a expressão dessas relações em termos matemáticos formais.

- Estabelecer as condições de contorno do problema, ou seja, da área objeto de intervenção e das alternativas de intervenção viáveis.

- Listar tipos de conseqüências que serão consideradas e estabelecer uma unidade de medida comum que possibilite compará-las em relação a critérios que especifiquem a preferência do decisor.

- Representar relações por meio de árvores de decisão, apresentando interdependências existentes entre as variáveis do problema.

- Estabelecer o critério de decisão.

De acordo com Scholl et al. (2004), alguns dos problemas de decisão têm as seguintes propriedades:

- As alternativas são caracterizadas por um número limitado de atributos relevantes e operacionais.

- Os atributos podem ser medidos numa escala arbitrária e representados por um número limitado de níveis discretos (por exemplo, distância grande, média ou pequena; desempenho bom, médio ou fraco).

- Os atributos são escolhidos de maneira que sejam independentes um de outro. O juízo de valor dum nível de atributo deve ser independente dos outros níveis que outros atributos 
possam ter. As alternativas possíveis podem ser construídas por combinações (quase) arbitrárias de níveis de diferentes atributos; particularmente, não devem ser estritamente correlacionadas estatisticamente.

- No entanto, os atributos são (parcialmente) conflitantes, i.e., melhorar o nível de um atributo deteriora o nível de pelo menos um outro.

- As alternativas que um tomador de decisões tem que avaliar são definidas por todas as possíveis combinações de níveis de atributo.

Os métodos multicriteriais são classificados em três grandes famílias: a teoria da utilidade multiatributo (enfoque do critério único de síntese, que exclui a incomparabilidade), os métodos de alta ordem (que aceitam a incomparabilidade) e os métodos iterativos (com interação tentativa-erro).

A primeira família (teoria da utilidade multiatributo) mostra como considerar conseqüências diferenciadas (ambiental, monetário ou social) por meio de uma função utilidade com atributos múltiplos. O processo transforma os valores das diversas conseqüências em unidades de utilidade, utilizando-se para essa transformação, as preferências do decisor codificadas através de mecanismos formais. A utilização da teoria de utilidade muliatributo aplicada ao gerenciamento de encostas foi apresentada detalhadamente por Carvalho (1996).

Os métodos de alta ordem (“outranking”) usam índices que medem a credibilidade da concordância ou discordância com a hipótese que uma alternativa $i$ supera uma alternativa $j$. A concordância permite medir se uma ação $i$ é melhor que outra $j$ pelo cálculo do peso total dos critérios a favor de $i$. A discordância é usada para respeitar a situação de ordenamento de $i$ sobre $j$, quando existe um critério para o qual $j$ é muito melhor que $i$. Esta metodologia se baseia numa relação binária, onde a qualidade das avaliações das ações e a natureza do problema permitem admitir que $i$ é ao menos tão boa quanto $j$ sem que haja uma razão importante para recusar esta afirmação. Estes métodos são mais aconselháveis quando o numero de ações não é muito grande (Baasch 1995). A utilização de um método de alta ordem aplicado à escolha do melhor traçado de rodovias foi apresentada detalhadamente por Galves (1995).

Esta pesquisa está centrada na última família, onde se encontra o método de análise hierárquica (AHP - “Analytic Hierarchy Process”). 


\subsection{Conceituação do Método de Análise Hierárquica (Analytic Hierarchy Process - AHP).}

O método de análise hierárquica foi introduzido por Thomas Saaty em 1977, e busca reproduzir o que parece ser um método natural de funcionamento da mente humana. A mente humana, ao encarar um grande número de elementos controláveis ou não, que abarca uma situação complexa, os junta em grupos segundo propriedades comuns.

O método inicialmente foi desenvolvido para solucionar um problema de planejamento de contingência em 1972, e a partir daí foi aplicado em vários outros projetos, até ganhar notoriedade através do livro "The Analityc Hierarchy Process", publicado em 1980. Desde então, tem tido aplicações ainda mais abrangentes, incluindo problemas econômicos/gerenciais (finanças, previsão macro-econômica, estratégia, planejamento, alocação de recursos, transporte, recursos hídricos), problemas políticos (controle de armas nucleares, conflitos e negociação, influência mundial), problemas sociais (educação, meio ambiente, saúde, jurídico, medicamentos), problemas tecnológicos (seleção de mercados, transferência tecnológica), entre outros (Morita 1998).

A grande vantagem do método é alternar etapas de cálculo com etapas de diálogo, ou seja, pressupõe uma intervenção contínua e direta do decisor ou de outros atores na construção da solução, e não somente na definição do problema (Baasch 1995). Quando vários objetivos são importantes para o decisor, pode ser difícil escolher entre as alternativas; neste caso o método de análise hierárquica é um instrumento que pode resolver problemas complicados onde os objetivos têm interações e correlações.

No AHP, as alternativas e os atributos, necessários para julgar as alternativas, se estruturam em uma hierarquia. No nível mais elevado fica o principal objetivo do problema de decisão. $\mathrm{O}$ objetivo principal deve ser decomposto em vários níveis inferiores de atributos; cada atributo pode ser subdividido, gerando uma árvore de atributos com um número arbitrário de níveis. A subdivisão termina quando se determina que os atributos são avaliadores dos objetivos dos níveis acima da árvore. Abaixo dos atributos elementares são colocadas as alternativas.

O cálculo da hierarquia é realizado de maneira ascendente. O tomador de decisões compara todos os pares de atributos em cada nível, começando pelos atributos elementares e subindo pela hierarquia até atingir o objetivo final (Saaty 1980). As preferências são encontradas por 
comparações paritárias, ou par a par ("pairwise"), das alternativas para cada atributo, usando uma escala de valor. A mesma escala é usada para determinar os pesos dos atributos por comparações paritárias dos critérios que têm o mesmo objetivo. As preferências das alternativas com respeito a seus níveis do atributo, chamadas prioridades, e os pesos dos atributos são calculados usando o método do autovalor ("eigenvalue"). A prioridade final ou total é computada por uma função de valor aditivo que resume as prioridades dos níveis de atributos.

Segundo Saaty (1980) e Morita (1998), as etapas da aplicação do AHP são divididas em:

- Estruturar os objetivos, critérios e alternativas em uma hierarquia, do problema global até os estágios mais específicos.

- Realizar os julgamentos comparativos de cada par de fatores de decisão (os fatores de decisão são alternativas, indicadores e critérios) em um dado nível, denominados comparações paritárias.

- Determinar as prioridades relativas dos pesos dos fatores de decisão, em cada nível ou grupo. Consolidar as prioridades relativas até o nível das alternativas, i.e. relacionar todos os pesos, propagando o efeito dos pesos na estrutura até o nível das alternativas. A recomendação da decisão é dada pela classificação das alternativas da decisão, ordenadas relativamente ao objetivo global.

- Uma etapa adicional é a verificação do nível da consistência dos dados de julgamentos de cada grupo.

A seguir serão detalhadas as etapas de desenvolvimento do AHP.

\subsection{Estruturação da hierarquia.}

O método de análise hierárquica se caracteriza por dividir um problema de decisão através do seu ordenamento em níveis hierárquicos. De um problema complexo, com múltiplos critérios, pode-se estruturar uma hierarquia com inúmeros níveis, fixando-se o objetivo principal do problema no primeiro nível, a definição dos critérios no segundo nível, e assim por diante.

A hierarquia pode ser definida como um sistema de níveis estratificados, cada um consistindo de diversos elementos ou fatores, ou como uma abstração da estrutura de um sistema para 
estudar as interações funcionais de seus componentes e respectivos impactos no sistema total (Baasch 1995).

Assim, o tomador de decisões deverá formular um objetivo global único, e dividir o sistema com critérios e indicadores atingindo esse objetivo. Na Figura 20 é apresentada uma estrutura hierárquica em forma de árvore invertida apresentada por Morita (1998), onde o objetivo único é representado pelo nó A e os critérios e indicadores apresentam-se nos níveis mais baixos; no ultimo nível da hierarquia estão as alternativas a serem ordenadas pelo método de análise. As alternativas devem estar, necessariamente, em um único nível. Um nó é um fator de decisão que pode ser um objetivo, critério ou alternativa.

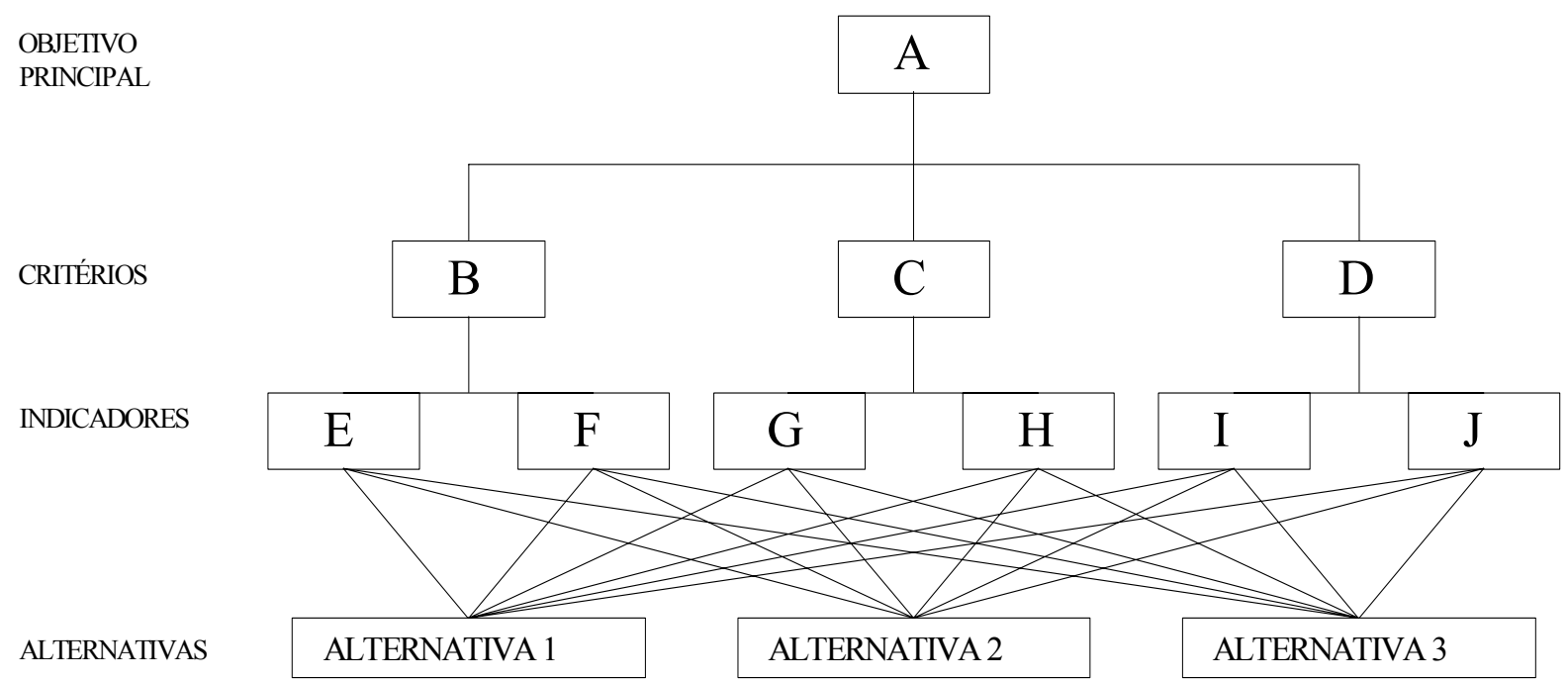

Figura 20. Modelo de hierarquização para avaliação de alternativas (Morita 1998).

Os grupos se caracterizam por estarem conectados a um mesmo elemento do nível imediatamente superior. Na Figura 20, os critérios B, C e D formam um grupo; os elementos E, F formam um grupo; G e $\mathrm{H}$ formam outro; e I, J também.

Os problemas e os sistemas são estruturados com base na somatória de experiências dos integrantes do grupo de decisão, que de maneira organizada listam as considerações, os critérios, os respectivos indicadores e os atores, concluindo por elaborar uma hierarquia; isto pode ser feito em reuniões "brainstorming" (Lisboa 2002). Os integrantes do grupo de decisão podem ter papéis ativos ou passivos, como decisores, informadores, executores, especialistas 
ou analistas, modeladores, vítimas, beneficiários, donos de processos e parceiros, e podem atuar em todo o processo de julgamento ou apenas em parte do mesmo.

De acordo com Morita (1998), três é o número mínimo de níveis possíveis no AHP e apenas os critérios podem ter vários níveis; quando os critérios ocupam mais de um nível os critérios inferiores são mais específicos do que aqueles que se encontram acima. Desta forma, a estruturação da hierarquia é chamada, às vezes, de estruturação de critérios.

\subsection{Julgamentos paritários.}

O principio básico da AHP é atribuir valores de julgamentos relativos por comparações de elementos paritariamente, isto é, dois a dois. Elementos são os fatores de decisão, que na árvore estão representados por nós do mesmo nível. Saaty (1980) utiliza uma escala de 1 a 9 para dar um valor quantitativo de um elemento preferido relativamente a outro elemento. $\mathrm{Na}$ Tabela 14 estão apresentados esses valores e seu significado.

Tabela 14. Escala de julgamento paritário (Saaty 1999).

\begin{tabular}{|c|c|c|}
\hline Intensidade & Definição & Explicação \\
\hline 1 & Mesma importância & Os dois critérios contribuem \\
\hline 3 & Importância pequena de uma sobre outra & $\begin{array}{l}\text { A experiência e o julgamento favorecem } \\
\text { levemente um critério em relação a outro }\end{array}$ \\
\hline 5 & Importância forte ou essencial & $\begin{array}{l}\text { A experiência e o julgamento favorecem } \\
\text { fortemente um critério em relação a outro }\end{array}$ \\
\hline 7 & Importância muito forte ou demonstrada & $\begin{array}{l}\text { Um critério é fortemente favorecido em } \\
\text { relação ao outro; sua dominação é demonstrada } \\
\text { na prática }\end{array}$ \\
\hline 9 & Importância absoluta & $\begin{array}{l}\text { A evidência favorece um critério em relação ao } \\
\text { outro com mais alto grau. }\end{array}$ \\
\hline $2,4,6,8$ & $\begin{array}{l}\text { Valores intermediários entre os valores } \\
\text { adjacentes }\end{array}$ & $\begin{array}{l}\text { Quando se procura uma condição de } \\
\text { compromisso entre duas definições }\end{array}$ \\
\hline $\begin{array}{l}\text { Recíprocos dos } \\
\text { valores acima de } \\
\text { zero }\end{array}$ & $\begin{array}{l}\text { Se atividade } i \text { recebe uma das designações } \\
\text { acima de zero, quando comparada com a } \\
\text { atividade } j \text {, então } j \text { tem valor recíproco quando } \\
\text { comparada com } i\end{array}$ & Uma designação razoável \\
\hline Racionais & Razões resultantes da escala & $\begin{array}{l}\text { Se a consistência tiver de ser forçada para } \\
\text { obter valores numéricos para completar a } \\
\text { matriz }\end{array}$ \\
\hline
\end{tabular}

O resultado dessas comparações é uma matriz de comparações paritárias ou matriz pareada, resultante dos julgamentos de um nível sob um determinado critério/indicador de decisão do nível imediatamente superior. A matriz tem a forma apresentada na equação (2): 


$$
A=\left[\begin{array}{cccc}
a_{11} & a_{12} & \ldots & a_{1 m} \\
a_{21} & a_{22} & \ldots & a_{2 m} \\
\vdots & \vdots & \ddots & \vdots \\
a_{m 1} & a_{m 2} & \cdots & a_{m m}
\end{array}\right]
$$

Onde $a_{i j}$ indica quanto mais importante é o elemento i-ésimo em relação ao elemento j-ésimo segundo a escala da Tabela 14.

As matrizes de comparações paritárias devem ser positivas, idênticas, recíprocas e consistentes (Saaty 1999), atendendo a três propriedades especiais:

- Identidade: todos os elementos na diagonal da matriz de comparações paritárias são iguais a 1 , ou seja, para todo $i$, é necessário que $a_{i i}=1$. Isto porque a diagonal principal representa cada elemento comparado a si mesmo, ou seja, de igual importância.

- Reciprocidade: cada elemento abaixo da diagonal da matriz de comparações paritárias é igual ao inverso do elemento correspondente acima da diagonal, isto é, $a_{i j}=1 / a_{j i}$. Por exemplo, se o atributo $A$ é julgado 2 vezes mais importante do que o atributo $B$, então o atributo $B$ tem $1 / 2$ da importância do atributo $A$.

- Consistência: a matriz de comparações deve satisfazer a propriedade de transitividade, o que significa que se $i$ é preferível a $j$ e $j$ é preferível a $k$, $i$ é preferível a $k$, ou seja, $a_{i j} a_{i k}=$ $a_{i k}, i, j, k=1, \ldots n$. Por exemplo, para quaisquer três atributos $A, B$ e $C$, se $A$ é julgado como $\mathrm{x}$ vezes mais importante que $B$, e $B$ é considerado como $z$ vezes mais importante que $C$, então $A$ deve ser $x z$ vezes mais importante que $C$. Segundo essa propriedade, as colunas da matriz de comparações paritárias são múltiplos escalares entre si, de forma que as colunas normalizadas (i.e onde cada célula é dividida pela soma da coluna) são idênticas, e qualquer uma delas pode representar os valores relativos das alternativas. Isto ocorre quando se tem uma transitividade cardinal perfeita, i.e. as comparações realizadas foram perfeitamente consistentes (Silva 2003). Porém, segundo Morita (1998), isto não acontece normalmente na prática, e é necessário utilizar o método do autovalor para analisar a consistência das comparações.

\subsection{Prioridades relativas.}

O AHP utiliza o método de autovalor ("eigenvalue") para determinar os pesos dos elementos da matriz pareada, a ordem de prioridade, e como uma medida da consistência do julgamento. 
Os elementos da matriz de comparações paritárias com colunas normalizadas denominam-se pesos. Em caso de consistência perfeita, essa matriz é composta de linhas de elementos iguais, enquanto a soma dos elementos de cada coluna é igual à unidade, podendo ser representada por um vetor $\mathrm{W}$ de $\mathrm{n}$ elementos, que são os pesos $w_{i}, \mathrm{i}=1, \ldots, \mathrm{n}$. Os pesos são portanto calculados pela equação (3):

$$
w_{i}=\frac{\sum_{j=1}^{n} a_{i j}}{n}
$$

Os elementos da matriz de comparações paritárias se relacionam com os pesos pela equação (4):

$$
a_{i j}=\frac{w_{i}}{w_{j}} \quad i, j=1, \ldots n
$$

A equação (4) é equivalente à equação (5):

$$
a_{i j} \frac{w_{j}}{w_{i}}=1 \quad i, j=1, \ldots n
$$

Conseqüentemente, chega-se à equação (6):

$$
\sum_{j=1}^{n} a_{i j} w_{j} \frac{1}{w_{i}}=n \quad i=1, \ldots, n
$$

O que equivale à equação (7):

$$
\mathrm{AW}=\mathrm{nW}
$$

Pela teoria das matrizes, o vetor W que satisfaz a equação (7) é um autovetor com autovalor $n$.

Em casos práticos, onde a reciprocidade da matriz de comparações paritárias não é perfeita, os elementos $a_{i j}$ se afastam da razão ideal $w_{i} / w_{j}$, e a equação (7) não é válida.

Porém, combinando-se as duas propriedades seguintes da teoria das matrizes, conclui-se que se a diagonal da matriz A consiste de elementos unitários $\left(a_{i j}=1\right)$ e se A for consistente, então pequenas variações de $a_{i j}$ mantêm o máximo autovalor $\lambda_{\max }$ perto de $\mathrm{n}$, e os demais autovalores próximos de zero:

- Se $\lambda_{1}, \ldots, \lambda_{n}$ são números satisfazendo a equação $\mathrm{A} x=\lambda \mathrm{x}$, ou seja, são autovalores de $\mathrm{A}$, e se $a_{i j}=1$ para todos $i$, então vale a equação (8): 


$$
\sum_{i=1}^{n} \lambda_{i}=n
$$

- Se os elementos $a_{i j}$ de um matriz recíproca foram modificados em pequenas quantidades, os autovalores se alteram em pequenas quantidades.

Assim, para encontrar o vetor prioridade, deve-se encontrar o vetor W que satisfaça a equação (9):

$$
\mathrm{Aw}=\lambda_{\max } \mathrm{w}
$$

A distância entre $\lambda_{\text {máx }}$ e n é, portanto, uma medida de consistência.

A partir desses conceitos, Saaty (1980) recomenda o procedimento a seguir para a verificação da consistência dos julgamentos e consolidação das prioridades.

Inicialmente, é feito o cálculo do autovetor de maneira aproximada através de três etapas:

- Somar o total de cada coluna da matriz de comparações.

- Normalizar a matriz, dividindo cada elemento pelo total da sua respectiva coluna, gerando a matriz $\mathrm{A}_{\mathrm{w}}$, apresentada na equação (10).

- Calcular a média aritmética de cada linha da matriz normalizada, gerando o vetor $\mathrm{C}$, apresentado na equação (11).

$$
A_{w}=\left[\begin{array}{ccccc}
\frac{a_{11}}{\sum_{i=1}^{m} a_{i 1}} & \frac{a_{12}}{\sum_{i=1}^{m} a_{i 2}} & \cdots & \cdots & \frac{a_{1 m}}{\sum_{i=1}^{m} a_{i m}} \\
\vdots & \vdots & \cdots & \cdots & \vdots \\
\vdots & \vdots & \ddots & & \vdots \\
\frac{a_{m 1}}{\sum_{i=1}^{m} a_{i 1}} & \frac{a_{m 1}}{\sum_{i=1}^{m} a_{i 2}} & \cdots & \cdots & \frac{a_{m m}}{\sum_{i=1}^{m} a_{i m}}
\end{array}\right]
$$




$$
\mathrm{C}=\left[\begin{array}{c}
\mathrm{c}_{1} \\
\vdots \\
\vdots \\
\vdots \\
\mathrm{c}_{\mathrm{m}}
\end{array}\right]=\left[\begin{array}{c}
\frac{\mathrm{a}_{11}}{\sum_{\mathrm{i}=1}^{\mathrm{m}} \mathrm{a}_{\mathrm{i} 1}}+\frac{\mathrm{a}_{12}}{\sum_{\mathrm{i}=1}^{\mathrm{m}} \mathrm{a}_{\mathrm{i} 2}}+\cdots+\frac{\mathrm{a}_{1 \mathrm{~m}}}{\sum_{\mathrm{i}=1}^{\mathrm{m}} \mathrm{a}_{\mathrm{im}}} \\
\mathrm{m} \\
\vdots \\
\vdots \\
\frac{\mathrm{a}_{\mathrm{m} 1}}{\sum_{\mathrm{i}=1}^{\mathrm{m}} \mathrm{a}_{\mathrm{i} 1}}+\frac{\mathrm{a}_{\mathrm{m} 2}}{\sum_{\mathrm{i}=1}^{\mathrm{m}} \mathrm{a}_{\mathrm{i} 2}}+\cdots+\frac{\mathrm{a}_{\mathrm{mm}}}{\sum_{\mathrm{i}=1}^{\mathrm{m}} \mathrm{a}_{\mathrm{im}}} \\
\mathrm{m}
\end{array}\right]
$$

$\mathrm{O}$ vetor $\mathrm{C}$ é o autovetor dos critérios/indicadores de decisão de cada nível. O mesmo processo deve ser aplicado para cada matriz de comparações abarcando toda a estrutura hierárquica do problema. Os elementos $c_{i}$ representam o grau relativo de importância do i-ésima elemento no vetor coluna de pesos de importância.

Em seguida, multiplica-se a matriz de comparações (A) paritárias pelo autovetor da solução estimada (vetor C), resultando um vetor coluna chamado por Morita (1998) de vetor das prioridades consolidadas, como apresentado na equação (12)

$$
\mathrm{A} \cdot \mathrm{C}=\left[\begin{array}{cccc}
\mathrm{a}_{11} & \mathrm{a}_{12} & \cdots & \mathrm{a}_{1 \mathrm{~m}} \\
\mathrm{a}_{21} & \ddots & \cdots & \vdots \\
\vdots & \vdots & \ddots & \vdots \\
\mathrm{a}_{\mathrm{m} 1} & \cdots & \cdots & \mathrm{a}_{\mathrm{mm}}
\end{array}\right]\left[\begin{array}{c}
\mathrm{c}_{1} \\
\mathrm{c}_{2} \\
\vdots \\
\mathrm{c}_{\mathrm{m}}
\end{array}\right]=\left[\begin{array}{c}
\mathrm{x}_{1} \\
\mathrm{x}_{2} \\
\vdots \\
\mathrm{xm}
\end{array}\right]
$$

Quando as colunas normalizadas não são idênticas aparece a inconsistência da matriz de comparações paritárias, requerendo uma avaliação da consistência. A consistência de uma matriz positiva recíproca requer que seu autovalor máximo, $\lambda_{\max }$, seja igual ao número de linhas (ou colunas) da matriz de comparações paritárias n. Quanto mais próximo $\lambda_{\max }$ for de $n$ mais consistente será o resultado. $\lambda_{\max }$ é calculado por meio da equação (13).

$$
\lambda_{\max }=\frac{1}{\mathrm{n}} \sum_{\mathrm{i}=1}^{\mathrm{n}} \frac{\mathrm{i} \text {-ésima entrada em } \mathrm{A} \times \mathrm{C}}{\mathrm{i} \text {-ésima entrada em C }}=\frac{1}{\mathrm{n}} \sum_{\mathrm{i}=1}^{\mathrm{n}} \frac{\mathrm{x}_{\mathrm{i}}}{\mathrm{c}_{\mathrm{i}}}
$$


O índice de consistência IC de uma matriz de comparações paritárias é usado para mostrar quanto o valor de $\lambda_{\max }$ está afastado do valor teórico esperado n, portanto o desvio é dado por $\left(\lambda_{\max }-n\right)$. Esta diferença é medida relativamente ao número de graus de liberdade desta matriz (n-1). Assim, o índice de consistência é dado pela equação (14)

$$
\mathrm{IC}=\frac{\lambda_{\max }-\mathrm{n}}{\mathrm{n}-1}
$$

Se IC é suficientemente pequeno, as comparações do decisor são provavelmente consistentes para dar estimações úteis dos pesos da função objetivo. $O$ índice de consistência é comparado com o índice randômico (IR) para o valor n (número de ordem da matriz de comparações paritárias) para determinar se o grau de consistência é satisfatório. O índice randômico representa o valor que seria obtido em uma matriz de comparações paritárias de ordem $\mathrm{n}$ em que não fossem feitos julgamentos lógicos, preenchendo-se os elementos com valores aleatórios. Os valores do índice randômico para diferentes matrizes do tipo matiz de comparações paritárias foram calculadas por Saaty (1980) e estão apresentados na Tabela 15.

Tabela 15. Índice randômico em função da ordem da matriz de comparações paritárias (Saaty 1980).

\begin{tabular}{|l|l|l|l|l|l|l|l|l|l|l|l|l|l|}
\hline Ordem & 3 & 4 & 5 & 6 & 7 & 8 & 9 & 10 & 11 & 12 & 13 & 14 & 15 \\
\hline IR & 0.52 & 0.89 & 1.11 & 1.25 & 1.35 & 1.40 & 1.45 & 1.49 & 1.51 & 1.54 & 1.56 & 1.57 & 1.58 \\
\hline
\end{tabular}

A razão de consistência permite analisar o grau de violação da proporcionalidade e transitividade dos julgamentos do decisor. A razão de consistência é calculada pela equação (15):

$$
\mathrm{RC}=\frac{\mathrm{IC}}{\mathrm{IR}}
$$

Adota-se que se IC/IR $<0.10$ o grau de consistência é satisfatório, mas se IC/IR $>0,10$ podem existir sérias inconsistências e o AHP não pode dar resultados significativos. Quando o grau de consistência é pobre (um índice de consistência maior do que 0,10), é necessário obter mais informações nas comparações dos critérios, ou seja, realizar uma coleta de informações a partir de uma nova avaliação de julgamentos (Marques 2002). Marques (2002) propõe que $\lambda_{\max }<\mathrm{n}+5 \%$, pois assim o índice de consistência (IC) sempre terá um valor próximo de 0 e a razão de consistência $(\mathrm{RC})$ sempre será menor do que 0,10 . 
Saaty ( 1999) dispensa a Tabela 15 por um critério de $\mathrm{IC}_{\text {máximo }}$, onde se a matriz é de ordem 3

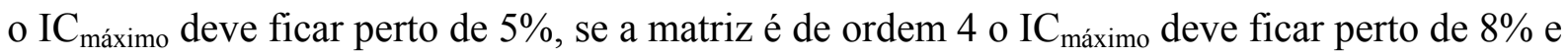

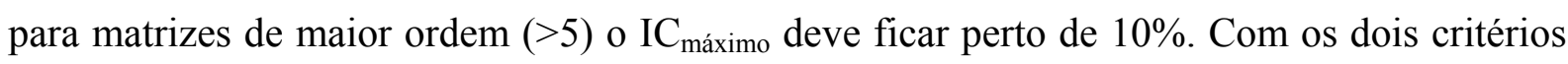
( $\mathrm{RC}$ e $\left.\mathrm{IC}_{\text {máximo}}\right)$, garante-se um nível tolerável de consistência dentro da estrutura hierárquica.

\subsection{Cálculo dos pesos finais.}

Segundo Morita (1998), para reduzir o efeito de reversão (ou reversão de ordem, i.e a troca da ordem das alternativas de decisão que pode levar a decisões radicalmente diferentes, que ocorre quando se retiram ou se incluem matrizes de comparações paritárias de critérios; ou pela variação na quantidade de alternativas) nos pesos finais, existem três modos de cálculo: o modo distributivo, o modo ideal e o modo absoluto.

O modo distributivo, onde os pesos totalizam o valor unitário, é a forma original de cálculo do AHP. É recomendado para priorizar alternativas de planejamento, para avaliar sob critérios que não se repetem e para alocação de recursos escassos. Morita (1998) compara esse modo com fatias de mercado: uma entrada de participantes com pequenas fatias provoca a redução da fatia do líder e também das distâncias entre os concorrentes; conforme as forças intervenientes no processo, o líder pode perder sua posição.

No modo ideal é atribuído o valor unitário para o peso da alternativa de maior prioridade, normalizando-se a seguir o vetor dos pesos resultantes. Este modo é recomendado quando se busca uma única e melhor alternativa de um conjunto, ou quando existem alternativas muito semelhantes, que não serão excluídas, mas apenas priorizadas. Morita (1998) exemplifica esse modo pela altura das pessoas: a quantidade de "baixinhos" não altera a posição do indivíduo mais alto. No modo ideal existe uma contenda individual, dando-se mais ênfase à seqüência que às medidas de classificação.

No modo absoluto é recomendado quando o numero de alternativas é alto, acima de 9 (por exemplo, com 10 alternativas são necessárias $[n(n-1) / 2]=45$ julgamentos). Permite que o modo de trabalho seja menos cansativo e mais direto quando o numero de alternativas é grande. 


\subsection{Variante multiplicativa do método de análise hierárquica.}

Infelizmente algumas normalizações e o uso de funções aditivas podem levar a resultados errôneos, como apresentado por Triantaphyllou (2001). Pode-se evitar o efeito do tipo de normalização (ideal ou distributiva) usando a versão multiplicativa do AHP.

O modelo usado é o chamado de produto de pesos (WPM - Weighted Product Model), onde duas alternativas são comparadas ao mesmo tempo segundo a equação (16).

$$
R\left(\frac{A_{K}}{A_{L}}\right)=\prod_{j=1}^{n}\left(\frac{a_{K j}}{a_{L j}}\right)^{W j}
$$

Se a proporção acima é maior ou igual que um, então a conclusão é que $A_{K}$ é melhor ou igual que $A_{L}$; obviamente, o peso da melhor alternativa é maior que os de todas as outras alternativas.

Sejam quaisquer três alternativas, $A_{1} A_{2} A_{3}$ com $n$ critérios de decisão. Suponha-se que a alternativa $A_{1}$ é preferível à alternativa $A_{2}$, i.e.: $A_{1}>A_{2}$, então de acordo com a equação (17) a seguinte relação deve ser verdade:

$$
\begin{aligned}
& \mathrm{R}\left(\frac{\mathrm{A}_{\mathbf{1}}}{\mathrm{A}_{2}}\right)=\prod_{\mathrm{i}=\mathbf{1}}^{\mathrm{n}}\left(\frac{\mathrm{a}_{\mathbf{1 i}}}{\mathrm{a}_{2 \mathrm{i}}}\right)^{\mathrm{Wi}}>\mathbf{1} \\
& \Leftrightarrow \prod_{\mathrm{i}=\mathbf{1}}^{\mathrm{n}}\left(\mathrm{a}_{1 \mathrm{i}}\right)^{\mathrm{Wi}}>\prod_{\mathrm{i}=\mathbf{1}}^{\mathrm{n}}\left(\mathrm{a}_{2 \mathrm{i}}\right)^{\mathrm{Wi}}
\end{aligned}
$$

A equação (17) pode ser aplicada às outras alternativas, (A2 > A3 e A1 > A3 ).

Esta variante deve ser aplicada na ultima etapa do AHP, quando a matriz de decisão se processa e os pesos das alternativas são determinados. Sua vantagem, segundo Triantaphyllou (2001) e uma aproximação em Moreno e Escobar (2000), é que existe uma independência em 
relação ao modelo de normalização (ideal ou distributivo), o que faz da variante multiplicativa uma ferramenta muito útil.

\subsection{Por que o método de análise hierárquica?}

$\mathrm{O}$ método de analise hierárquica foi escolhido para esta pesquisa devido às seguintes características (Marques 2002, Lisboa 2002, Morita 1998, Baasch 1995):

- Permitir uma visão global das relações inerentes ao processo.

- Permitir comparações em vários níveis e ser flexível quanto à entrada e retirada de dados.

- Integrar dados e ser eficaz na combinação dos vários atributos obtidos.

- Permitir estruturação hierárquica do problema e poder avaliar um grande número de fatores quantitativos e qualitativos, de maneira sistemática, sob critérios múltiplos e conflitantes.

- Ser matematicamente simples, o que facilita a multidisciplinaridade.

- Proporcionar uma estrutura flexível, aproximando da realidade as tomadas de decisão em vários âmbitos.

- A abordagem da solução é do tipo "dividir para conquistar".

- O resultado final permite definir uma seqüência cardinal da importância dos critérios e das alternativas.

- Não obriga que os fatores sejam necessariamente representados em termos de valores econômico-financeiros, técnicos ou físicos.

- Intervenção contínua e direta do decisor ou de outros atores na construção da solução e não somente na definição do problema. 


\section{METODOLOGIA.}

Para a utilização do método de análise hierárquica como apoio à tomada de decisões na localização de barragens de contenção de rejeitos de mineração, utilizou-se a metodologia proposta por Lisboa (2002) e explicada a seguir.

Inicialmente procurou-se definir o maior número de atributos relevantes para esta aplicação, formulando-se uma tabela geral de atributos para escolha de locais para barragens de rejeitos.

Definiu-se um estudo de caso, que é a seleção de local para a nova barragem de rejeitos de minério cobre da MINER S.A no município de Carmen de Atrato, na Colômbia.

Antes da aplicação do AHP, utilizou-se um avaliador geológico de prospecção do tipo geoquímico para isolar zonas onde há indícios fortes de existência importante de minério, ou seja, zonas de mineralização. Essas zonas serão possivelmente futuras zonas de exploração de minério e devem ser evitadas como locais de barragens de rejeitos.

Depois de isolar os locais que não apresentam quantidades importantes de minério, foram levantados dados das áreas que podem servir para a construção de barragens de rejeitos, que são as alternativas a serem analisadas pelo AHP.

Desenvolveu-se inicialmente um conjunto de critérios e indicadores, sua hierarquização e unidades de medida, com base em Lisboa (2002). A seguir esses critérios e indicadores foram redefinidos considerando o envolvimento de especialistas, e finalmente foi feita uma nova redefinição deste conjunto de critérios e indicadores considerando a disponibilidade de dados no estudo de caso. Essas informações foram utilizadas para a avaliação das alternativas de local frente aos critérios e sub-critérios da hierarquia.

A elaboração da hierarquia foi feita com base no objetivo geral de menor impacto ambiental. Procurou-se definir e detalhar os principais tipos de impacto que uma barragem de rejeitos geraria na região, gerando os níveis mais baixos da hierarquia, sempre com o objetivo de minimizar o impacto ambiental correspondente. No último nível foram colocadas as 
alternativas de local, e todas as informações coletadas em campo com base na tabela geral de atributos foram utilizadas para avaliar as preferência entre as alternativas.

A análise de custos foi feita separadamente para cada alternativa, e no final se confrontam custos com pesos resultantes da análise hierárquica.

\subsection{Definição de atributos relevantes.}

Os atributos relevantes foram definidos da seguinte forma:

- revisão bibliográfica sobre os fatores que influenciam a escolha de locais de implantação de barragens de rejeitos (itens 4.1 a 4.5 do Capítulo 4)

- formulação de uma tabela resumo a partir dos dados obtidos na revisão bibliográfica (item 4.6 do Capítulo 4, Tabela 13)

\subsection{Estudo de caso.}

Utilizou-se a região do município de Carmen de Atrato, na Colômbia, onde já está implantada uma mineradora de minério de cobre, supondo a escolha de um local para uma nova barragem de rejeitos. O estudo de caso está apresentado mais detalhadamente no Capítulo 7.

\subsection{Avaliador geológico de prospecção.}

$\mathrm{Na}$ localização de uma área para a construção de uma barragem de rejeitos, o primeiro que pensa o minerador é que a barragem não fique num local que possa ter concentrações de minério importantes.

Com ajuda da geoquímica se estabelecem as condições de contorno do problema em nível local. A análise geoquímica é um método indireto e baseia-se na medição sistemática de uma ou várias propriedades químicas do material natural, para determinar o teor de um elemento ou de um grupo de elementos. O material natural inclui rochas, solos, capas de hidróxidos de ferro, sedimentos glaciais, vegetação, sedimentos de rios e lagos, água e vapor.

A geoquímica está enfocada no descobrimento de distribuições anômalas de elementos. No estudo de caso, são reportadas anomalias em sedimentos de drenagem, particularmente nas correntes de riachos, e que são chamadas na geoquímica de sedimentos ativos; são eles os 
materiais utilizados para um reconhecimento geral da região no caso de prospecção para minérios de cobre. Os sedimentos ativos de correntes de água incluem materiais clásticos de drenagens naturais, nascentes, leitos dos riachos e outros.

Definem-se como elementos exploradores os seguintes elementos: Ouro (Au), Prata (Ag), Zinco $(\mathrm{Zn})$, e Chumbo $(\mathrm{Pb})$, que são os indicadores para o tipo de depósito da área.

Retiram-se amostras de sedimentos ativos da região em estudo e determinam-se concentrações dos elementos exploradores por meio de análise química.

O avaliador geológico de prospecção foi utilizado pela Mineradora MINERA S.A. na região do estudo de caso e os resultados estão apresentados no item 7.3 do Capítulo 7 e no Anexo 2

\subsection{Definição de indicadores.}

Os indicadores apresentados na Tabela 16 são o resultado da reavaliação da Tabela 13, selecionados como os mais significativos para efeito de análise.

A seguir, segundo as recomendações de Lisboa (2002), foram feitas reuniões com especialistas ("brainstorming”) para redefinir quais indicadores seriam os mais adequados para este tipo de estudo. Nesta dissertação colaboraram cinco profissionais especialistas que atuam em obras mineradoras. Idealmente todos os especialistas devem estar juntos nas reuniões de "brainstorming", mas isto não foi possível: foi feita uma reunião com três especialistas e entrevistas individuais com os outros dois.

Houve ainda uma revisão final dos dados a partir da experiência profissional, resultando na formulação de uma tabela de indicadores para a escolha de locais para barragens de rejeitos, apresentada na Tabela 17. Observa-se que, como resultado do "brainstorming" e da revisão final, reduziu-se a quantidade de indicadores.

O conjunto de indicadores da Tabela 17 pode ser considerado como um conjunto de fatores básicos de análise, configurando uma avaliação de áreas para barragens de rejeitos tanto em nível regional como local. Foram, então, coletadas as informações relativas a cada indicador, para utilização posterior na análise hierárquica. 


\section{Tabela 16 Indicadores sugeridos.}

\begin{tabular}{|c|c|c|c|c|}
\hline \multicolumn{4}{|c|}{ INDICADORES } & \multirow{3}{*}{$\begin{array}{|ll|} & \text { UNIDADES } \\
\text { R\$ } & \\
\% \text { inclinação } & \\
\end{array}$} \\
\hline \multirow{14}{*}{ ASPETOS TOPOGRAFICOS } & Custos iniciais & & & \\
\hline & \multirow{9}{*}{ Relevo } & \multirow{3}{*}{ Formas } & Encosta Plana & \\
\hline & & & Encosta íngreme & \% inclinação \\
\hline & & & Zonas marginais de inundação & Nenhuma-moderada - excessiva \\
\hline & & \multirow{3}{*}{ Declividade } & Baixa (5-10\%) & $\%$ \\
\hline & & & Media $(10-25 \%)$ & $\%$ \\
\hline & & & Alta $(>25 \%)$ & $\%$ \\
\hline & & \multirow{3}{*}{ Distancia do limite entre bacias hidrográficas } & $>200 \mathrm{~m}$ & $\mathrm{~m}$. \\
\hline & & & $200-100 \mathrm{~m}$. & $\mathrm{m}$. \\
\hline & & & $<100 \mathrm{~m}$. & $\mathrm{m}$. \\
\hline & \multirow{4}{*}{ Tipo de Arranjo e Disposição } & \multirow{2}{*}{\multicolumn{2}{|c|}{\begin{tabular}{|l|} 
Montante (em vale - bacia - meia encosta) \\
\end{tabular}}} & Sim - não \\
\hline & & & & Sim - não \\
\hline & & \multirow{2}{*}{\multicolumn{2}{|c|}{\begin{tabular}{|l|} 
Linha de centro (em vale - bacia - meia encosta) \\
Opcões especiais (Cavas, submarina, subterrânea, em pit)
\end{tabular}}} & Sim-não \\
\hline & & & & Sim-não \\
\hline \multirow[t]{39}{*}{ ASPETOS GEOLOGICOS GEOTECNICOS } & \multirow{15}{*}{ Substrato Rochoso - Fundações } & \multirow{3}{*}{ Resistência } & Rocha fraca & $5,0-25 \mathrm{MPa}$. \\
\hline & & & Rocha mediamente resistente a resistente & 25-100 MPa. \\
\hline & & & $\begin{array}{l}\text { Rocha muito resistente } \\
\end{array}$ & $100-250 \mathrm{MPa}$. \\
\hline & & \multirow{3}{*}{ Descontinuidades } & Blocos muito grandes - grandes & $\mathrm{JV}(<1-3)$ \\
\hline & & & Blocos médios - pequenos & \begin{tabular}{|l|l|}
$J V(3-30)$ \\
\end{tabular} \\
\hline & & & Blocos muito pequenos & $\mathrm{JV}>30$ \\
\hline & & \multirow{3}{*}{ Litología } & Metamórfica & \begin{tabular}{|l|} 
Tipo de rocha \\
\end{tabular} \\
\hline & & & Sedimentaria & \begin{tabular}{|l|} 
Tipo de rocha \\
\end{tabular} \\
\hline & & & Ignea & Tipo de rocha \\
\hline & & \multirow{3}{*}{ Profundidade } & $<5 \mathrm{~m}$ & $\mathrm{~m}$. \\
\hline & & & $5-20 \mathrm{~m}$ & $\mathrm{~m}$. \\
\hline & & & $>20 \mathrm{~m}$ & $\mathrm{~m}$. \\
\hline & & \multirow{3}{*}{ Mergulho } & $<10^{\circ}$ & Grados \\
\hline & & & $10^{\circ}-60^{\circ}$ & Grados \\
\hline & & & $>60^{\circ}$ & Grados \\
\hline & \multirow{18}{*}{ Materiais inconsolidados } & \multirow{5}{*}{ Textura } & Pedregulho & Classificação Sistema unificado \\
\hline & & & Areia & Classificicąão Sistema unificado \\
\hline & & & Silte & Classificação Sistema unificado \\
\hline & & & Argila & \begin{tabular}{|l|} 
Classificcação Sistema unificado \\
\end{tabular} \\
\hline & & & Solo orgânico & \begin{tabular}{|l|} 
Classificação Sistema unificado \\
\end{tabular} \\
\hline & & \multirow{3}{*}{ Matacões } & Maior dimensão & m. \\
\hline & & & Freqüência & Und $/ 1000 \mathrm{~m}^{3}$ \\
\hline & & & profundidade & $\mathrm{m}$. \\
\hline & & & Homogêneo. & Continuo - descontinuo \\
\hline & & | Variaçấo vertical. & Heterogêneo. & Continuo - descontinuo \\
\hline & & Características de compactação & Proctor normal & Adequada - inadequada \\
\hline & & & $>10^{-2}$ & $\mathrm{~cm} . / \mathrm{s}$ \\
\hline & & Permeabilidade & $10^{-3} 10^{-7}$ & $\mathrm{~cm} / \mathrm{s}$ \\
\hline & & & $<10^{-7}$ & $\mathrm{~cm} . / \mathrm{s}$ \\
\hline & & & Residual & Ocorre - não ocorre \\
\hline & & & Coluvião & Ocorre - não ocorre \\
\hline & & Tipo de deposito & Aluvião & Ocorre - não ocorre \\
\hline & & & Glacial & \begin{tabular}{|l|} 
Ocorre - não ocorre \\
\end{tabular} \\
\hline & & \begin{tabular}{|l|l|l|l} 
Falhas \\
\end{tabular} & & \begin{tabular}{|l|} 
Direção \\
\end{tabular} \\
\hline & Estruturas geológicas & Zonas de minério & & Possíveis - não possíveis \\
\hline & Processos & & Freqüência & Ocorre - não ocorre \\
\hline & & Movimentos de massa gravitacionais & Intensidade & No $/ \mathrm{Km}^{2}$ \\
\hline & & & Freqüência & Ocorre - não ocorre \\
\hline & & Subsidências & Intensidade & No $/ \mathrm{Km}^{2}$ \\
\hline
\end{tabular}




\begin{tabular}{|c|c|c|c|c|}
\hline & & \multirow[b]{2}{*}{ Feições cársticas } & Freqüência & Ocorre - não ocorre \\
\hline & & & \begin{tabular}{|l|} 
Intensidade \\
\end{tabular} & $\mathrm{No} / \mathrm{Km}^{2}$ \\
\hline & & \multirow{2}{*}{ Erosão } & Freqüência & Ocorre - não ocorre \\
\hline & & & \begin{tabular}{|l|} 
Intensidade \\
\end{tabular} & $\mathrm{No} / \mathrm{Km}^{2}$ \\
\hline \multirow{14}{*}{ ASPETOS HIDRICOS } & \multirow{8}{*}{ Águas subterrâneas } & \multirow{3}{*}{ Profundidade da zona saturada } & $>6 \mathrm{~m}$ & $\mathrm{~m}$. \\
\hline & & & $<4 \mathrm{~m}$ & m. \\
\hline & & & $<2 \mathrm{~m}$ & $\mathrm{~m}$. \\
\hline & & \multirow{2}{*}{ Fluxo saturado } & Direção & No de direções \\
\hline & & & \begin{tabular}{|l|} 
Vazão \\
\end{tabular} & $\mathrm{m} . / \mathrm{s}$ \\
\hline & & \multirow{3}{*}{ Risco de poluição } & Alto & 25 \\
\hline & & & Médio & 12,5 \\
\hline & & & Baixo & 0,2 \\
\hline & \multirow{6}{*}{ Áreas de captação } & \multirow[t]{3}{*}{\begin{tabular}{|l|} 
Distancia da nascente \\
\end{tabular}} & $>500 \mathrm{~m}$. & $\mathrm{m}$. \\
\hline & & & $500-300 \mathrm{~m}$ & m. \\
\hline & & & $<300 \mathrm{~m}$ & m. \\
\hline & & \multicolumn{2}{|l|}{\begin{tabular}{|l|} 
Condições de drenagem \\
\end{tabular}} & Bem drenada - Mal drenada \\
\hline & & \multirow{2}{*}{ Fluxo superficial } & \begin{tabular}{|l} 
Correntes de água \\
\end{tabular} & Laminar - concentrado \\
\hline & & & Escoamento superficial & Laminar - concentrado \\
\hline \multirow{7}{*}{ ASPETOS CLIMATICOS } & \multirow{2}{*}{ Taxa anual de precipitação } & \multicolumn{2}{|l|}{$<1500 \mathrm{~mm} / \mathrm{ano}$} & mm./ano \\
\hline & & $>2000 \mathrm{~mm} / \mathrm{ano}$ & & $\mathrm{mm} . /$ ano \\
\hline & \multirow{3}{*}{ Evotranspiração } & \multicolumn{2}{|l|}{$>1000 \mathrm{~mm}$} & $\mathrm{~mm}$. \\
\hline & & \multicolumn{2}{|l|}{$1000-600 \mathrm{~mm}$} & $\mathrm{~mm}$. \\
\hline & & \multicolumn{2}{|l|}{$<600 \mathrm{~mm}$} & $\mathrm{~mm}$. \\
\hline & Vento & Direção & & \begin{tabular}{|l} 
À zona urbana \\
\end{tabular} \\
\hline & Vento & \begin{tabular}{|l|} 
Velocidade \\
\end{tabular} & & \begin{tabular}{|l|}
$\mathrm{m} . / \mathrm{s}$ \\
\end{tabular} \\
\hline & & Capacidade de armazenamento & \begin{tabular}{|l|} 
área \\
Volume \\
\end{tabular} & $\frac{\mathrm{m}^{2}{ }^{2}}{\mathrm{~m}{ }^{3}}$ \\
\hline & & & Favorável & \begin{tabular}{|l|}
$\%$ extensão \\
\end{tabular} \\
\hline & & Acessos & Com algumas restrições & \% extensão \\
\hline & & & \begin{tabular}{|l|l|} 
Restrito \\
\end{tabular} & \% extensão \\
\hline & Local & & \begin{tabular}{|l|l|}
$<1 \mathrm{~km}$ \\
\end{tabular} & \begin{tabular}{|l|}
$\mathrm{Km}$ \\
\end{tabular} \\
\hline & & Distancia do local da mina & $1 \mathrm{~km}-10 \mathrm{~km}$ & $\mathrm{Km}$ \\
\hline & & & $>10 \mathrm{Km}$ & $\mathrm{Km}$ \\
\hline ASPETOS OPERACIONAIS & & & $<50 \mathrm{~m}$ cabeça estática & m. \\
\hline & & Necessidade de bombeamento & \begin{tabular}{|l|}
$50-100 \mathrm{~m}$. \\
\end{tabular} & $\mathrm{m}$. \\
\hline & & & $>100 \mathrm{~m}$ & m. \\
\hline & & Velocidade de denosicão & Alta & $\mathrm{cm} . / \mathrm{sg}$ \\
\hline & & & \begin{tabular}{|l|l|} 
Baixa \\
\end{tabular} & $\mathrm{cm} . / \mathrm{sg}$ \\
\hline & & & \begin{tabular}{|l|} 
densidade \\
\end{tabular} & Ton/m. ${ }^{3}$ \\
\hline & Rejeltos & Características fisicas - químicas & pH (acido - alcalino) & $\mathrm{PH}$ \\
\hline & & Caracteristicas fisicas - quimicas & \begin{tabular}{|l|}
$\%$ sólidos por peso \\
\end{tabular} & $\%$ \\
\hline & & & \begin{tabular}{|l|} 
Temperatura \\
\end{tabular} & ${ }^{\circ}{ }^{\circ} \mathrm{C}$. \\
\hline & & Unidades produtivas e de uso inter & & ${\mathrm{m} .{ }^{2}}^{2}$ \\
\hline & & \begin{tabular}{|l} 
Unidades habitacionais \\
\end{tabular} & & Número de residências \\
\hline & & Unidades de vegetação nativa & & $\mathrm{m}^{2}{ }^{2}$ \\
\hline USOS DO SOLO & Impactos no uso do solo. & Unidades de reflorestamento, paste & & $\mathrm{m}^{2}{ }^{2}$ \\
\hline USOS DU SOLO & & Unidades de parques nacionais, ec & os ou arqueológicos. & ${\mathrm{m} .{ }^{2}}_{2}$ \\
\hline & & \begin{tabular}{|l|} 
Unidades minérias na área \\
\end{tabular} & & $\mathrm{m}^{2}{ }^{2}$ \\
\hline & & \begin{tabular}{|l} 
Interferências com recursos hídricc \\
\end{tabular} & & Numero de cursos dagua \\
\hline & Impactos no meio físico & Impactos na qualidade do ar & & \% de extensão \\
\hline & Demografia & & & Habitantes $/ \mathrm{km}^{2}$ \\
\hline & População economicamente ativa & & & $\%$ \\
\hline & & \begin{tabular}{|l|l} 
Aqueduto \\
\end{tabular} & & $\%$ cobertura de serviço \\
\hline ASPETOS SOCIO - FCONOMICOS & Serviços Públicos & \begin{tabular}{|l|} 
Saneamento \\
\end{tabular} & & \% cobertura de serviço \\
\hline ASPETOS SOCIO - ECONOMICOS & & \begin{tabular}{|l|} 
Energia \\
\end{tabular} & & \% cobertura de serviço \\
\hline & & \begin{tabular}{|l|} 
Setor agrícola \\
\end{tabular} & & \% população \\
\hline & Atividades produtivas & \begin{tabular}{|l|} 
Setor ganadeiro \\
\end{tabular} & & \% população \\
\hline & & \begin{tabular}{|l|} 
Setor mineiro \\
\end{tabular} & & \% população \\
\hline
\end{tabular}


Tabela 17 Indicadores depois das reuniões "Brainstormig”.

\begin{tabular}{|c|c|c|c|c|}
\hline \multicolumn{4}{|c|}{ INDICADORES } & \multirow{2}{*}{ UNIDADES } \\
\hline NIVEL 1 & NIVEL 2 & \multirow{2}{*}{\multicolumn{2}{|c|}{ NIVEL 3}} & \\
\hline ASPETOS ECONOMICOS & Custos iniciais & & & $\mathrm{R} \$$ \\
\hline \multirow{6}{*}{ RELEVO } & \multirow{3}{*}{\multicolumn{2}{|c|}{ Formas }} & Encosta Plana & \% inclinação \\
\hline & & & Encosta íngreme & \% inclinação \\
\hline & & & Zonas marginais de inundação & $\begin{array}{l}\text { Nenhuma -moderada - } \\
\text { excessiva }\end{array}$ \\
\hline & \multirow{3}{*}{\multicolumn{2}{|c|}{ Declividade }} & Baixa $(5-10 \%)$ & $\%$ \\
\hline & & & Media (10-25\%) & $\%$ \\
\hline & & & Alta $(>25 \%)$ & $\%$ \\
\hline \multirow{39}{*}{$\begin{array}{c}\text { ASPETOS } \\
\text { GEOLOGICOS } \\
\text { GEOTECNICOS }\end{array}$} & \multirow{12}{*}{$\begin{array}{c}\text { Substrato Rochoso - } \\
\text { Fundações }\end{array}$} & \multirow{3}{*}{ Resistência } & Rocha fraca & $5,0-25 \mathrm{MPa}$. \\
\hline & & & $\begin{array}{l}\text { Rocha mediamente resistente a } \\
\text { resistente }\end{array}$ & $25-100 \mathrm{MPa}$. \\
\hline & & & Rocha muito resistente & $100-250 \mathrm{MPa}$. \\
\hline & & \multirow{3}{*}{ Litología } & Metamórfica & Tipo de rocha \\
\hline & & & Sedimentaria & Tipo de rocha \\
\hline & & & Ígnea & Tipo de rocha \\
\hline & & \multirow{3}{*}{ Profundidade } & $<5 \mathrm{~m}$ & $\mathrm{~m}$. \\
\hline & & & $5-20 \mathrm{~m}$ & $\mathrm{~m}$. \\
\hline & & & $>20 \mathrm{~m}$ & $\mathrm{~m}$. \\
\hline & & \multirow{3}{*}{ Mergulho } & $<10^{\circ}$ & Grados \\
\hline & & & $10^{\circ}-60^{\circ}$ & Grados \\
\hline & & & $>60^{\circ}$ & Grados \\
\hline & \multirow{17}{*}{ Materiais inconsolidados } & \multirow{5}{*}{ Textura } & Pedregulho & $\begin{array}{l}\text { Classificação Sistema } \\
\text { unificado }\end{array}$ \\
\hline & & & Areia & $\begin{array}{l}\text { Classificação Sistema } \\
\text { unificado }\end{array}$ \\
\hline & & & Silte & $\begin{array}{l}\text { Classificação Sistema } \\
\text { unificado }\end{array}$ \\
\hline & & & Argila & $\begin{array}{l}\text { Classificação Sistema } \\
\text { unificado }\end{array}$ \\
\hline & & & Solo orgânico & $\begin{array}{l}\text { Classificação Sistema } \\
\text { unificado }\end{array}$ \\
\hline & & \multirow{3}{*}{ Matacões } & Maior dimensão & $\mathrm{m}$. \\
\hline & & & Freqüência & Und $/ 1000 \mathrm{~m}^{3}$ \\
\hline & & & profundidade & $\mathrm{m}$. \\
\hline & & Variacão vertical & Homogêneo. & Continuo - descontinuo \\
\hline & & V arıaçao vertıcal. & Heterogêneo. & Continuo - descontinuo \\
\hline & & & $>10^{-2}$ & $\mathrm{~cm} . / \mathrm{s}$ \\
\hline & & Permeabilidade & $10^{-3} 10^{-1}$ & $\mathrm{~cm} . / \mathrm{s}$ \\
\hline & & & $<10^{-7}$ & $\mathrm{~cm} . / \mathrm{s}$ \\
\hline & & & Residual & Ocorre - não ocorre \\
\hline & & Tino de denosito & Coluvião & Ocorre-não ocorre \\
\hline & & 1 1po de deposito & Aluvião & Ocorre - não ocorre \\
\hline & & & Glacial & Ocorre-não ocorre \\
\hline & & Movimentos de & Freqüência & Ocorre - não ocorre \\
\hline & & massa gravitacionais & Intensidade & $\mathrm{No} / \mathrm{Km}^{2}$ \\
\hline & & & Freqüência & Ocorre - não ocorre \\
\hline & Processos & Subsidencias & Intensidade & $\mathrm{No} / \mathrm{Km}^{2}$ \\
\hline & Processos & Feicões cársticas & Freqüência & Ocorre - não ocorre \\
\hline & & Feiçoes carstıcas & Intensidade & $\mathrm{No} / \mathrm{Km}^{2}$ \\
\hline & & Frocão & Freqüência & Ocorre - não ocorre \\
\hline & & Erosao & Intensidade & $\mathrm{No} / \mathrm{Km}^{2}$ \\
\hline & Fstruturas osológicas & Falhas & Direção & Interfere - não interfere \\
\hline & Estruturas geologicas & Zonas de Minério & Concentração & Ocorre - não ocorre \\
\hline & & & $>6 \mathrm{~m}$ & $\mathrm{~m}$. \\
\hline & Profundidade da zona satu & ada & $<4 \mathrm{~m}$ & $\mathrm{~m}$. \\
\hline AGUAS & & & $<2 \mathrm{~m}$ & $\mathrm{~m}$. \\
\hline SUBTERRANEAS & & & Alto & 25 \\
\hline & Risco de poluição & & Médio & 12,5 \\
\hline & & & Baixo & 0,2 \\
\hline & & & $\begin{array}{l}\text { Unidades produtivas e de uso } \\
\text { intensivo }\end{array}$ & $\mathrm{m}^{2}$ \\
\hline & & & Unidades habitacionais & Número de residências \\
\hline & & & Unidades de vegetação nativa & $\mathrm{m}^{2}$ \\
\hline USOS DO SOLO & Impactos no uso do solo. & & $\begin{array}{l}\text { Unidades de reflorestamento, } \\
\text { pastagem e agricultura. }\end{array}$ & $\mathrm{m}^{2}$ \\
\hline & & & $\begin{array}{l}\text { Unidades de parques nacionais, } \\
\text { ecossistemas sensitivos ou } \\
\text { arqueológicos. }\end{array}$ & $\mathrm{m}^{2}$ \\
\hline & & & Interferências com recursos hídricos & n. ${ }^{\circ}$ cursos de água $/ \mathrm{km}$ \\
\hline & Impactos no meio físico & & Impactos na qualidade do ar & \% extensão. \\
\hline
\end{tabular}




\section{ESTUDO DE CASO.}

Para o estudo de caso utilizou-se a região do município de Carmen de Atrato, na Colômbia, onde já está implantada uma mineradora de minério de cobre, supondo a escolha de um local para uma nova barragem de rejeitos.

É importante esclarecer que na Colômbia a construção de barragens para a deposição de rejeitos de mineração é uma proposta nova, pois até recentemente estes eram descartados sem controle sobre terreno natural ou cursos d'água. Só há registro de barragens de rejeitos em duas regiões do país, sendo uma delas a região escolhida para o estudo de caso.

\subsection{Localização e estradas de acesso.}

A área de estudo localiza-se no Estado de Chocó no município de Carmen de Atrato ao noroeste da Colômbia, na margem esquerda da cordilheira ocidental. Dista de $546 \mathrm{Km}$ da capital da Colômbia, Bogotá, e de $146 \mathrm{Km}$ da cidade de Medellín, capital do Estado de Antioquia. As coordenadas geodésicas são: longitude $76^{\circ} 9^{\prime} \mathrm{W}$ e latitude $5^{\circ} 56^{\prime} \mathrm{N}$.

O acesso à área de estudo se faz pela estrada Medellín - Município de Caldas - Município de Bolombolo - Município de Ciudad Bolívar - Município de Carmen de Atrato em quatro horas por rodovia pavimentada. Na Figura 21 e Figura 22 estão apresentando os mapas de localização do município de Carmen de Atrato e da área de estudo, respectivamente.

\subsection{Caracterização do meio físico - biótico.}

São descritos alguns aspectos da área de estudo relevantes para esta pesquisa. Também são definidos os fatores comuns aos locais identificados como possíveis para a construção da barragem, ou seja, os fatores que não serão considerados por não diferenciarem as alternativas.

\subsubsection{Mina.}

A $3 \mathrm{Km}$ do município de Carmen de Atrato fica a Mineradora MINER S.A, empresa que extrai minério de calcopirita, ouro e prata de um depósito de sulfetos tipo Chipre. 

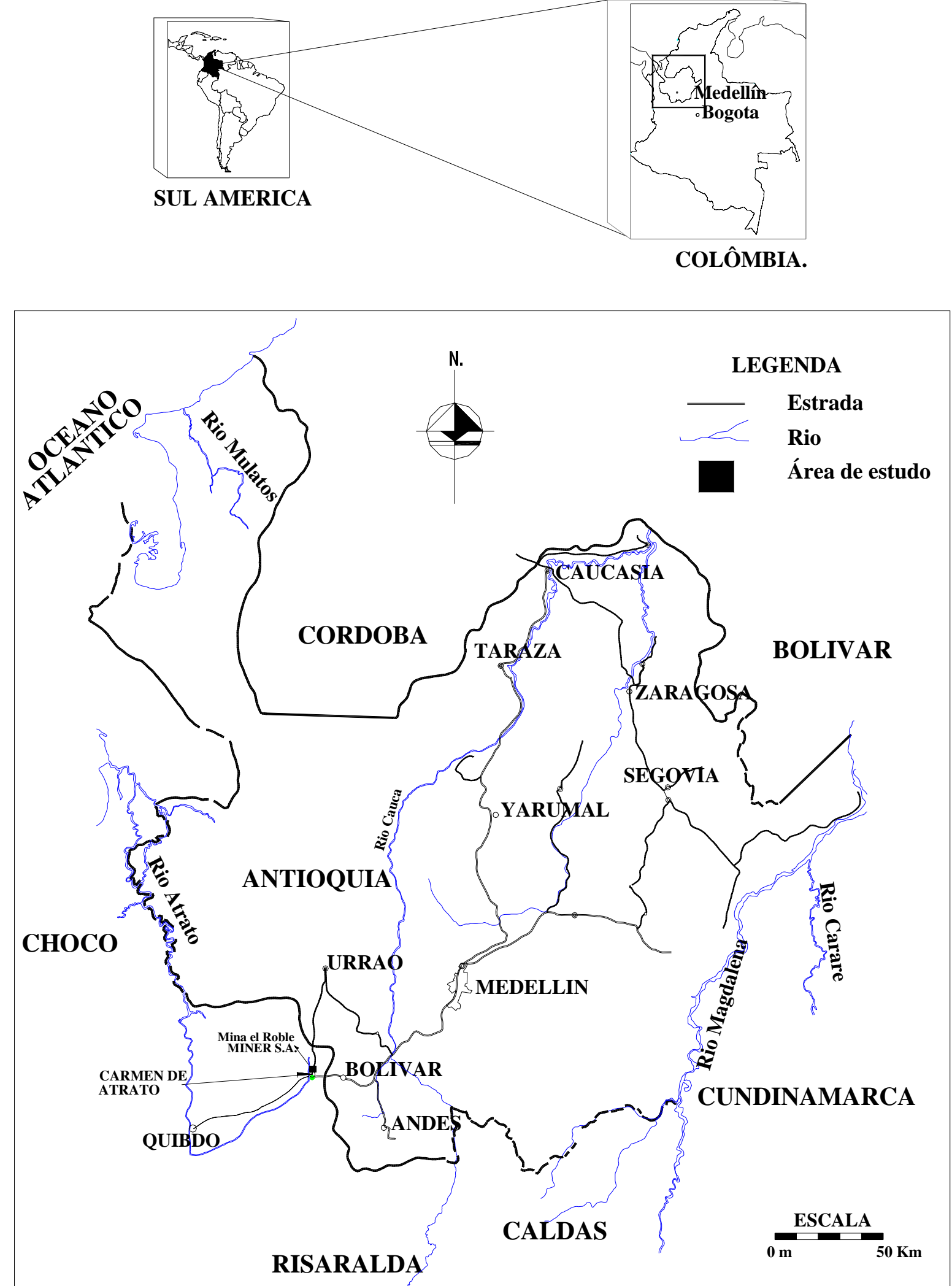

Figura 21. Localização geográfica do Município de Carmen de Atrato. 


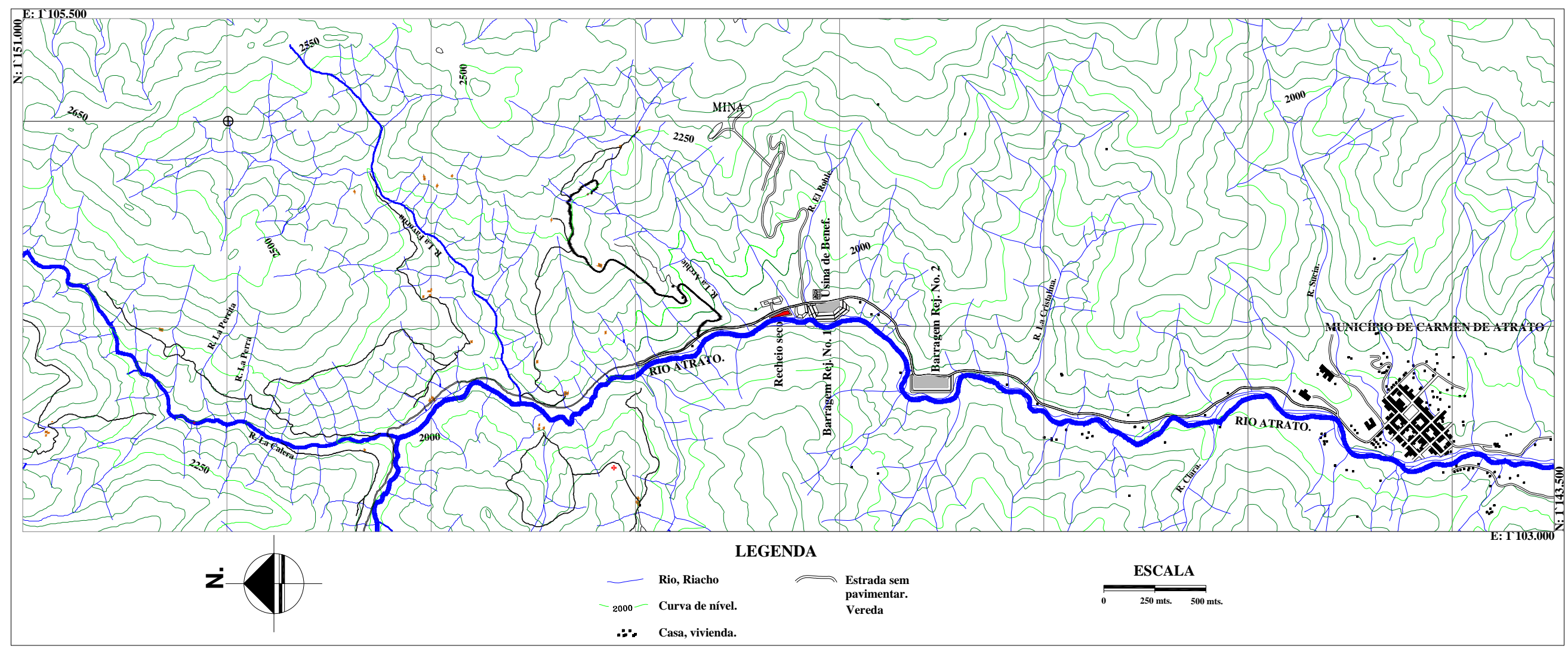

Figura 22. Localização da área de estudo. 
Esses minérios são extraídos da interface duma seqüência de rochas sedimentares marinhas com rochas vulcânicas de idade Cretácea. A extração se faz de forma subterrânea, pelo método de "cut and fill" (corte e aterro) ou pelo método de "sublevel stoping" (câmaras por subníveis). Na Figura 23 se apresenta uma seção típica do depósito de minério, e dois túneis de produção. Atualmente os trabalhos de extração e produção estão entre os níveis 2100 a 200 msnm (metros sobre o nível do mar).

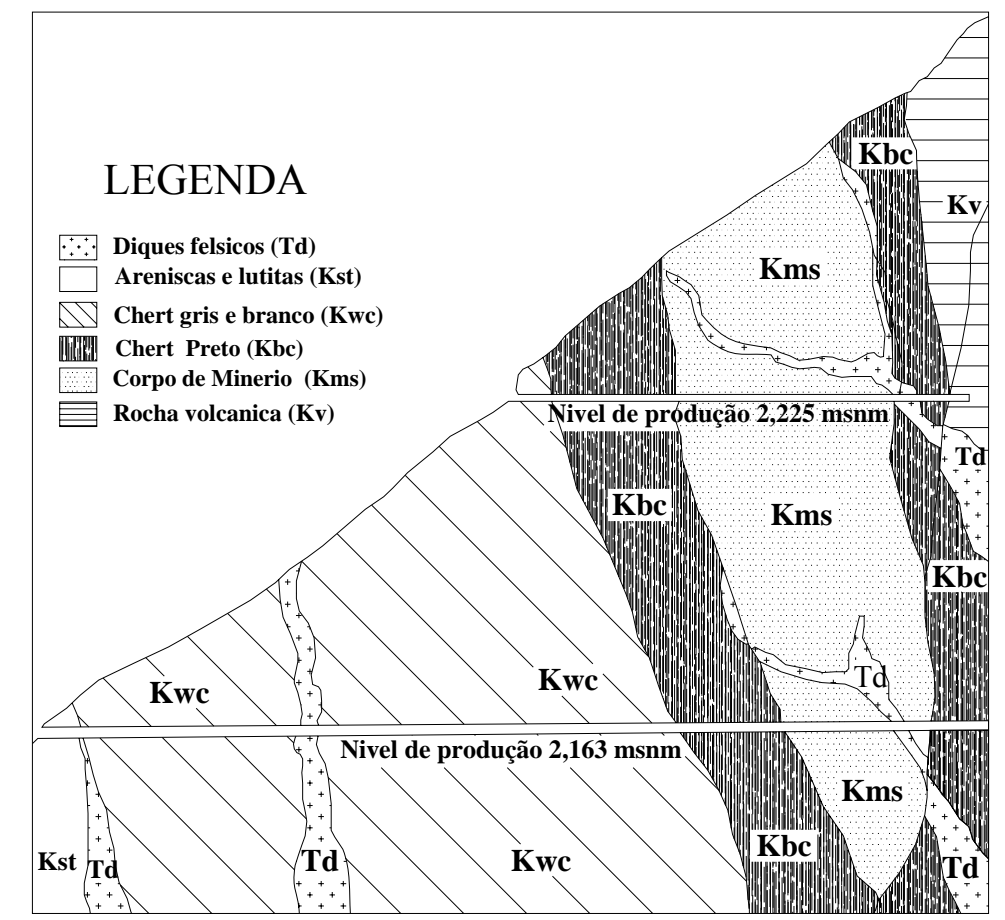

Figura 23. Seção típica do depósito de minério.

\subsubsection{Usina de beneficiamento e barragens de rejeitos.}

O minério extraído é beneficiado numa usina com capacidade para processar 400 ton/dia. O minério sai da mina com dimensão de aproximadamente $300 \mathrm{~mm}$ e na usina é britado e moído até ser reduzido a um tamanho de $0,057 \mathrm{~mm}$, com a finalidade de separar os minerais de calcopirita (minério de cobre), ouro e prata, dos materiais inservíveis. A separação é feita por flotação diferencial, onde se geram concentrados de calcopirita e rejeitos.

A densidade especifica dos rejeitos secos é 2.0; diariamente são depositados 270 ton de rejeitos. Os rejeitos saem da usina de beneficiamento com $30 \%$ de sólidos por peso e são armazenados em barragens; no momento, há duas barragens feitas pelo método de montante, uma (a barragem No 2) fora de operação. A quantidade de rejeitos que gera a mina é de 70.000 ton/ano, e as capacidades de armazenagem da barragem No 1 é de 100.000 ton. Conta- 
se com um mecanismo de deposição de rejeitos chamado de "recheio seco", onde os rejeitos são decantados na barragem No 1, tirando-se a máxima quantidade possível de água. Assim os rejeitos ficam mais secos e podem-se transportar facilmente por caminhões a um local perto da usina de beneficiamento. Este local tem uma capacidade de armazenamento de 210.000 ton de rejeitos, isto é, para 3 anos de operação, e a seleção de um novo local para a construção duma barragem é uma prioridade.

A mineradora escolhia os locais só tendo em conta os aspetos econômicos, mas com as novas legislações ambientais, é preciso vincular todos os aspetos requeridos por uma obra destas características.

\subsubsection{Produção de resíduos e contaminantes.}

Os resíduos que gera a mina são de dois tipos: sólidos e líquidos.

Os resíduos sólidos são chamados estéreis quando são produzidos pelas atividades de extração de minério, e rejeitos quando são produzidos pela usina de beneficiamento. A produção de estéreis alcança 20 ton/mês, que são dispostas em superfície na saída dos túneis de produção (nível 2162, 2100 e 2000).

Os resíduos líquidos são constituídos pelas águas freáticas que saem diretamente dos túneis de extração de minério e pelas águas geradas na usina de beneficiamento e nas barragens de rejeitos. Na Tabela 18 se apresentam algumas características das drenagens da mina e dos efluentes das barragens de rejeitos

Tabela 18. Características das drenagens da mina e dos efluentes das barragens de rejeitos.

\begin{tabular}{|c|c|c|c|}
\hline \multirow{2}{*}{ PARÂMETRO } & \multirow{2}{*}{ MINA } & \multicolumn{2}{|c|}{ BARRAGENS DE REJEITOS } \\
\cline { 3 - 4 } & & AFLUENTE & EFLUENTE \\
\hline Temperatura ${ }^{\circ} \mathrm{C}$ & 16 & 18 & 6,64 \\
\hline $\mathrm{pH}$ & 7,92 & 8,96 & 1490 \\
\hline Sólidos totais (mg/L) & 3525 & 22220 & 45 \\
\hline Sólidos em suspensão (mg/L) & 435 & 21840 & 63 \\
\hline DBO (mg/L) & 12,1 & 2225 & 72,5 \\
\hline DQO (mg/L) & 64,5 & 5978 & \\
\hline
\end{tabular}




\subsubsection{Geologia local.}

Duas grandes unidades litológicas têm sido cartografadas como principais:

- Uma unidade vulcânica (correlacionada com a formação Barroso), de idade Cretácea, caracterizada por ser um complexo de lava composto por diabásio, basalto, lava, tufo, brecha e aglomerados; seus afloramentos encontram-se situados no eixo montanhoso que divide as bacias dos rios Habita e Atrato.

- Uma unidade sedimentar (formação Penderisco) com dois membros, um constituído por rochas sedimentares clásticas (membro Urrao), composto por conglomerados, arenitos e lutitos, e outro formado por rochas de origem biogênica e/ou química (membro Nutibara), composto por "chert" preto, cinza e branco. O membro Nutibara encaixa depósitos de mineralizações importantes. Situa-se do lado da unidade vulcânica e estratigraficamente sob a Formação Barroso. O membro Urrao fica junto, como os dedos das mãos entrelaçadas da formação Nutibara. Na Figura 25 é apresentada a geologia da área, baseada em dados de campo e em informações de fotografias aéreas (Figura 24).

\subsubsection{Geomorfología.}

O relevo em geral é abrupto e muito íngreme, com declividade transversal média de $55^{\circ}$, chegando em alguns pontos até $80^{\circ}$, o que implica condições naturais muito favoráveis para promover fenômenos erosivos intensos.

O potencial erosivo se vê especialmente favorecido pelas condições atuais do uso do solo, a perda de cobertura florestal, a geomorfologia e em especial a declividade do terreno e a alta precipitação pluvial. Predominam fenômenos de movimentos de massa, principalmente nas vertentes que vão às correntes de água; observam-se problemas de rastejo.

A drenagem geral se dá pelo rio Atrato, que forma um estreito vale de seção triangular, com terraços aluviais de altura variável. O fluxo pela zona é turbulento, típico dos rios andinos, com alta capacidade de deslocar sedimentos e de blocos de rocha arredondados.

A área de estudo tem uma forte variação altimétrica, alcançando nos pontos mais altos a cota 2500 acima do mar, e nos mais baixos, 1700 acima do mar. 


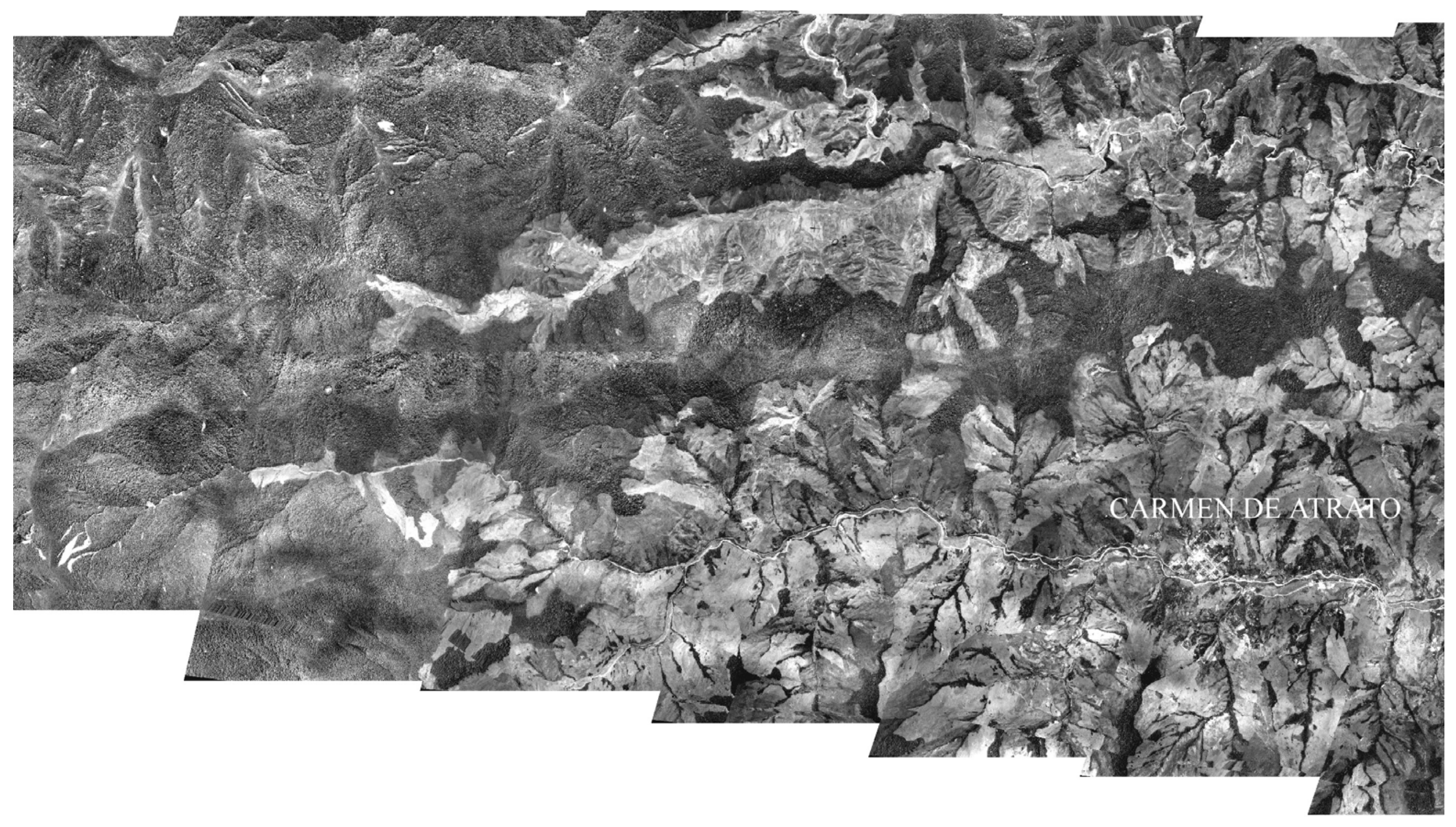

Figura 24. Mosaico das fotografias aéreas. 


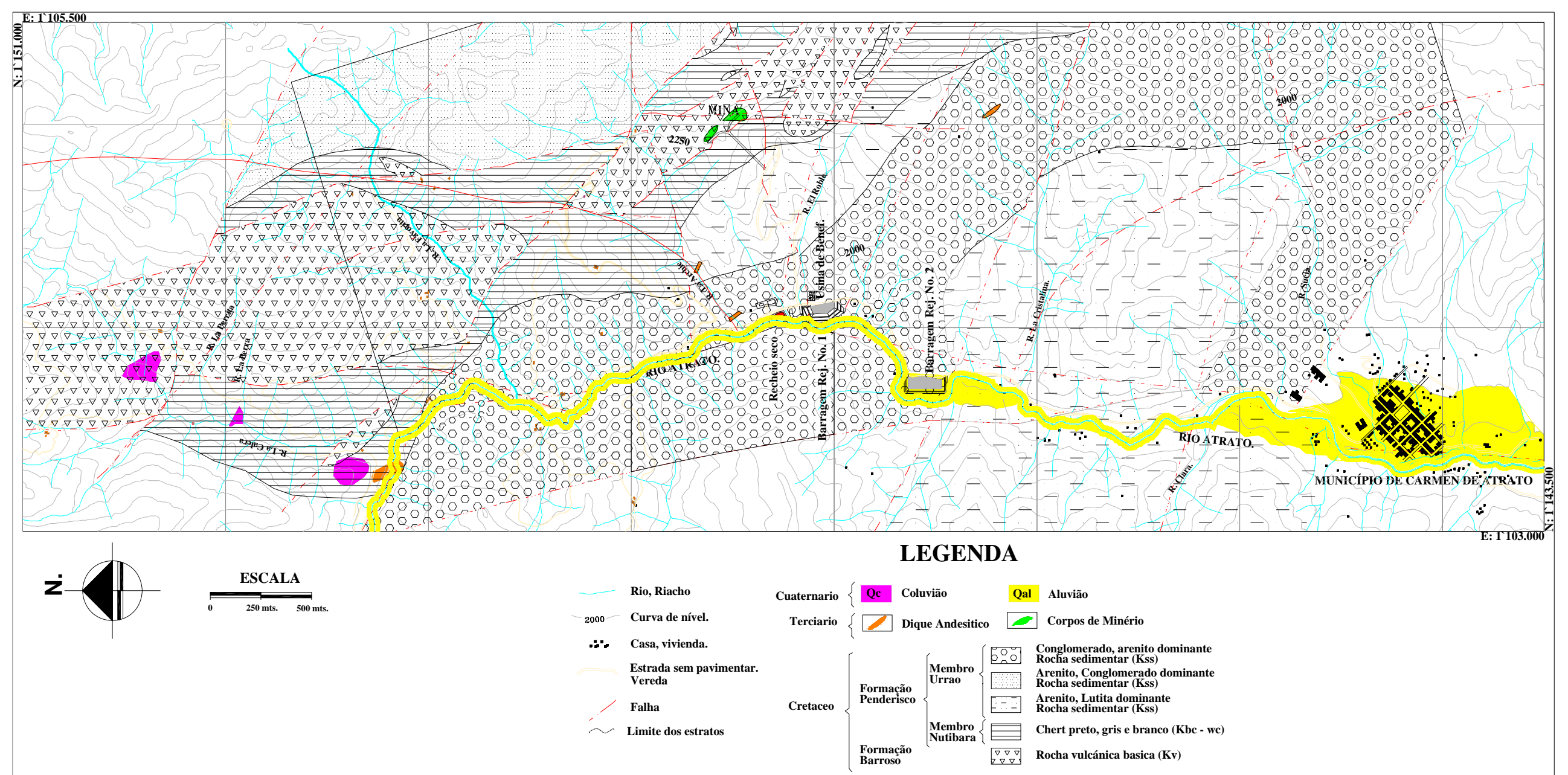

Figura 25. Geologia Local. 


\subsubsection{Hidrografia e dinâmica fluvial.}

O Rio Atrato na área de influência drena no sentido N-S, por um estreito vale, onde o comprimento máximo é de 3 a 7 metros. O rio fica limitado por acidentes topográficos e geológicos que fazem pequenos estreitamentos do canal aluvial. A profundidade média é de 1 a 1,5 m nos pontos onde se estreita. O regime de fluxo é turbulento. À margem oriental observam-se três níveis de terraços aluviais, de espessura variável entre 1 e 3 metros, onde predominam horizontes argilo-siltosos. O leito do rio é constituído por rochas de grande tamanho e de cantos não arredondados originadas dos afluentes e de solos sedimentares. A erosão é alta, mais nas cabeceiras dos riachos afluentes e principalmente na parte ocidental, onde se apresentam áreas desmatadas. Os afluentes deságuam no rio em forma de cachoeira, formando amplos depósitos de sedimentos transportados desde as cabeceiras e gerados pela erosão superficial de movimentos de massa.

Mesmo que o fluxo seja permanente, a variação de vazão é grande, registrando-se em geral vazões baixas, com mudanças súbitas e vazões instantâneas muito elevadas originadas em tormentas de variada intensidade e agravadas pela falta de cobertura vegetal da bacia.

Os principais cursos de água, localizados na área de estudo são:

Margem direita: Riacho La Clara e 18 riachos sem nome.

Margem esquerda: Riachos: La Calera, La Favorita, La Archie, El Roble, La Cristalina, e outros 22 riachos sem nome.

A área onde se localiza a mina e a usina de beneficiamento é drenada pelo riacho El Roble. Nesta bacia se localizam os principais impactos das atividades da mineradora, principalmente pelos líquidos originados nas drenagens naturais dos túneis de produção.

\subsubsection{Hidrologia.}

$\mathrm{Na}$ área de estudo o comportamento das vazões é bimodal, com um período de vazões baixas entre os meses de janeiro e fevereiro, e entre os meses de julho e setembro, quando a média é inferior à vazão média multianual, sendo março o mês de vazões mais baixas; os períodos com vazões mais altas são entre abril e julho e entre setembro e dezembro, sendo novembro o 
mês dos maiores fluxos. A Tabela 19 apresenta a vazão do rio medida no ponto "Puente Sanchez", que fica a $2 \mathrm{Km}$ na zona sul do Carmen de Atrato.

Tabela 19. Comportamento da vazão do Rio Atrato no ponto "Puente Sanchez".

\begin{tabular}{cc}
\hline MÊS & $\mathrm{m}^{3} / \mathrm{seg}$ \\
\hline Janeiro & 5,9 \\
Fevereiro & 4,7 \\
Março & 4,5 \\
Abril & 10,3 \\
Maio & 12,5 \\
Junho & 12,4 \\
Julio & 9,0 \\
Agosto & 8,5 \\
Setembro & 8,0 \\
Outubro & 12,2 \\
Novembro & 12,8 \\
Dezembro & 9,6 \\
\hline Média Multianual & 9,2 \\
\hline
\end{tabular}

\subsubsection{Clima.}

A área de estudo fica na vertente ocidental da cordilheira ocidental da Colômbia, sob influência das condições meteorológicas dos oceanos Pacífico e Atlântico, que definem fatores como as calmarias equatoriais, regime dos ventos ocidentais (alísios e corrente de Humbolt), a estrutura orográfica, e sua situação em relação à frente intertropical de convergência, e dão lugar a uma área superúmida. A precipitação média anual é de $2.374 \mathrm{~mm}$, uma média mensal multianual de 197,8 mm, e uma média anual de dias de chuva de $188 \mathrm{~mm}$ por ano (ver Anexo 1). A precipitação máxima observada foi de $1.131 \mathrm{~mm} / \mathrm{mês}$ e a mínima de $25 \mathrm{~mm} / \mathrm{mês}$. A tendência de umidade é de um período seco entre os meses de janeiro e março seguido dum período úmido entre abril e dezembro, com um verão pequeno em julho e outro em setembro. O mês mais seco é fevereiro e o mais úmido é outubro. A temperatura média é de $17^{\circ} \mathrm{C}$, com poucas variações. As condições definidas pelas precipitações dão lugar a um comportamento muito homogêneo, com uma umidade relativa de $90 \%$. A velocidade dos ventos é relativamente baixa e sua direção é geralmente sul, com uma velocidade inferior a $2 \mathrm{Km} / \mathrm{hr}$.

\subsubsection{Flora.}

As condições de precipitação, temperatura e altitude em relação ao nível do mar definem, segundo o modelo de Holdridge, uma zona de formação vegetal do tipo bosque muito úmido 
baixo de montanha (bmh-MB). Não resta muito do bosque original ou primário, no entanto nos pontos mais altos, acima da cota $2300 \mathrm{msnm}$, há algumas áreas com bosque secundários em processo de sucessão. A maioria das terras é utilizada para pastoreio e agricultura, dando lugar a fortes processos erosivos, acelerados pela alta umidade e pelas encostas íngremes.

\subsubsection{Fauna.}

As estruturas atuais do bosque e as áreas virgens determinam a composição da fauna. Não existem estudos detalhados, mas os testemunhos dos camponeses da área reportam alguns mamíferos (morcegos, ratões, felinos menores, veados, tamanduás), répteis, aves e fauna aquática (muito pobre devido fundamentalmente às condições hidráulicas e morfológicas da bacia), mas sem nenhum inventário conhecido da fauna existente.

\subsubsection{Usos do solo.}

$\mathrm{Na}$ área se observam os seguintes usos do solo:

- Agricultura: Atividade primária, cultivos de milho, feijão, cebola, banana da terra, hortaliças. Em geral é uma agricultura de subsistência.

- Pecuária: De tipo extensivo, utilizam-se terras de encostas de alto declive, que favorece os processos erosivos. Os produtos principais são o leite e a carne.

- Reflorestamento: Atividade não muito desenvolvida e de baixa intensidade.

- Mineração: A principal atividade mineradora é feita pela empresa MINER S.A na produção de minérios de calcopirita - ouro - prata.

\subsubsection{Caracterização do substrato rochoso.}

A caracterização das unidades que formam o substrato rochoso foi realizada com base em fotointerpretação, observações de campo e estudos e mapas pré-existentes (NITTETSU 1991; Ortiz, 1988; Arango, 2003)

\subsubsection{Rochas vulcânicas cretáceas (kv).}

Esta unidade é a mais antiga da região e representa o embasamento onde estão suportadas as demais unidades litológicas da área. Em geral são rochas diabásicas com textura ofiolítica e 
basaltos com textura irregular. Mineralogicamente estas rochas vulcânicas são constituídas por plagioclásio e clinopiroxênios com pequenas quantidades de olivina, ortopiroxênio, magnetita, pirita, e em alguns casos, ilmenita e calcopirita. Trata-se duma faixa alongada na direção N-S, com espessura entre 900 a 1200 metros. Em geral se apresenta em contato com rochas sedimentares químicas ("chert"). Internamente algumas zonas encontram-se altamente cisalhadas, gerando zonas de argila de falha (Figura 28, Figura 29)

\subsubsection{Rochas sedimentares químicas cretáceas (kbc - wc).}

Trata-se duma série de camadas de "chert" de cor branco, cinza e preto, localizadas ao lado da rocha vulcânica, apresentando a forma de um antigo anticlinal ou camadas mais grossas alternadas de rochas vulcânicas e sedimentares. Estas camadas apresentam espessuras variáveis; na parte ocidental da área de estudo a espessura varia entre 90 a 120 metros, a orientação é N-S, com mergulhos fortes entre 70 e $80^{\circ}$. Na parte oriental a espessura é menor, entre 60 e 80 metros no máximo, e apresenta mergulhos verticais a subverticais, apresentando intercalações com lutitas pretas de espessuras entre 15 e $60 \mathrm{~cm}$ (Figura 26 e Figura 27)

\subsubsection{Rochas sedimentares clásticas cretáceas (kss).}

Estas rochas apresentam o teto da seqüência sedimentar. Sua composição é de lutitas na base, arenitos e dolomitos no meio e conglomerados na parte superior. Todas estas unidades apresentam variações no interior, encontrando-se intercalação de arenitos finos na camada de lutitas, e lutitas no meio da camada de arenitos, assim como arenitos conglomeráticos entre arenitos. Esta unidade compreende duas faixas nos extremos oriental e ocidental da zona, com espessuras maiores de 1000 metros, apresentando orientações N-S, com mergulhos fortes a leste (Figura 28, Figura 29).

\subsubsection{Depósitos quaternários (coluvião (qc) - aluvião (qal)).}

Compreendidos como deslizamentos de solo e rocha fraturada que sofrem meteorização e transporte, suavizam a topografia das cotas mais elevadas das drenagens e das margens do rio Atrato (Figura 28, Figura 29). O rio Atrato tem uma dinâmica importante na zona de estudo, e são características as corridas de massa que provocam remoção de depósitos aluviais superficiais. 


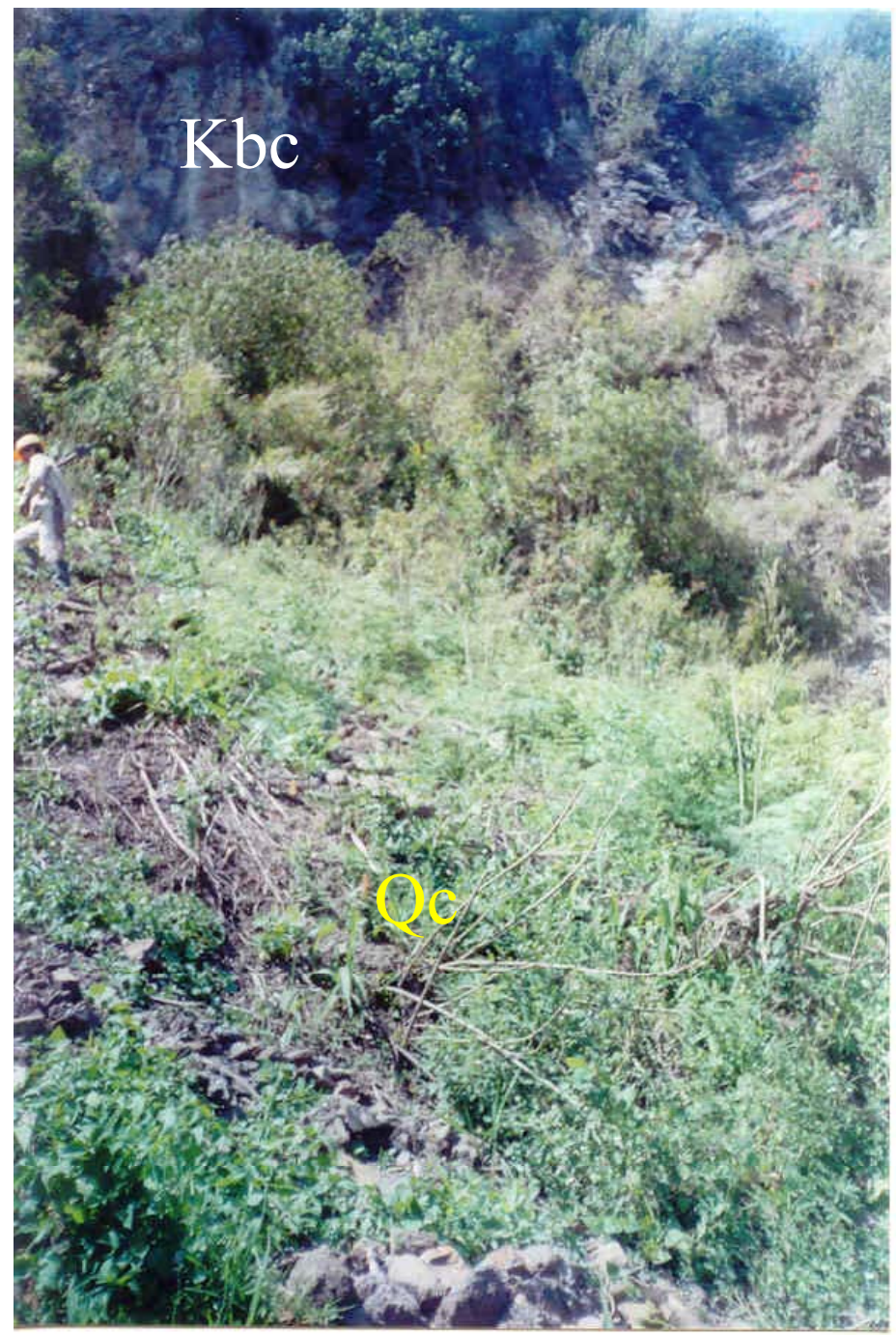

Figura 26. Maciço rochoso com escarpa de falha, que situa o contato de rocha sedimentar clástica (Kss) com chert negro (Kbc). No declive há acumulação de coluvião (Qc) de grandes blocos.

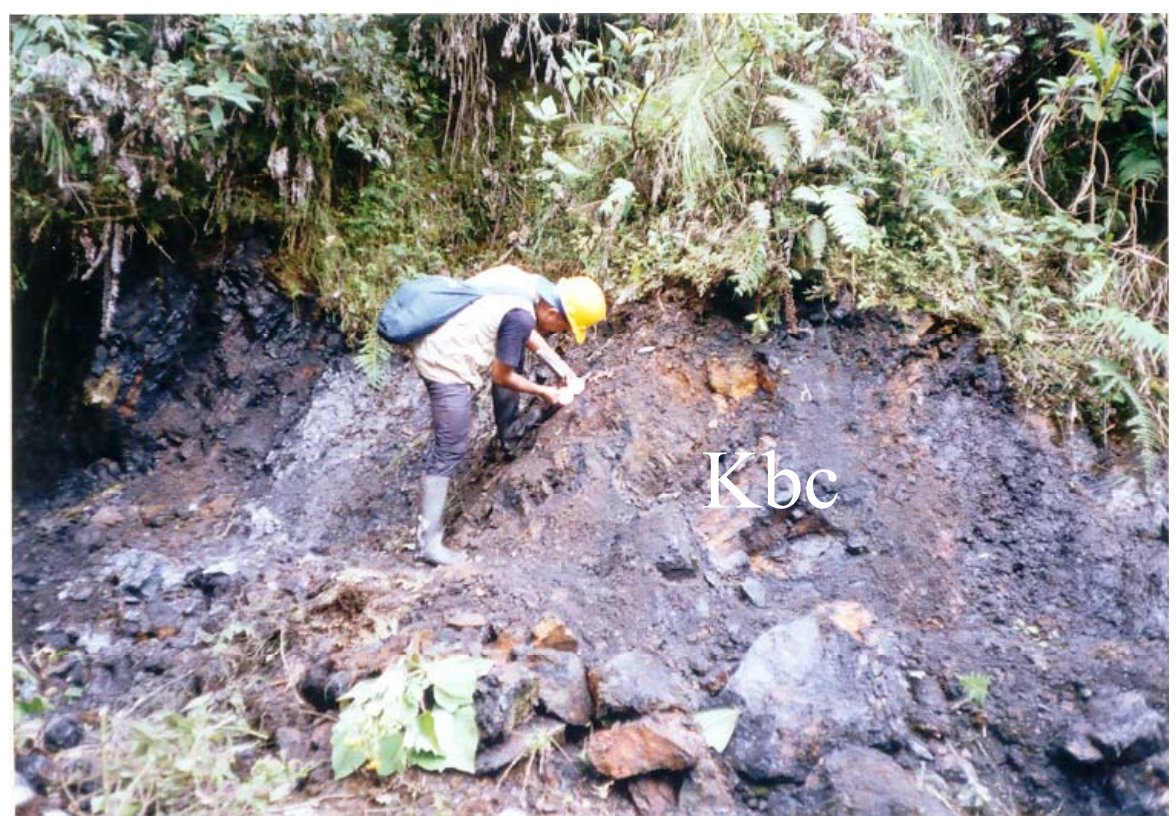

Figura 27. “Chert” preto. 


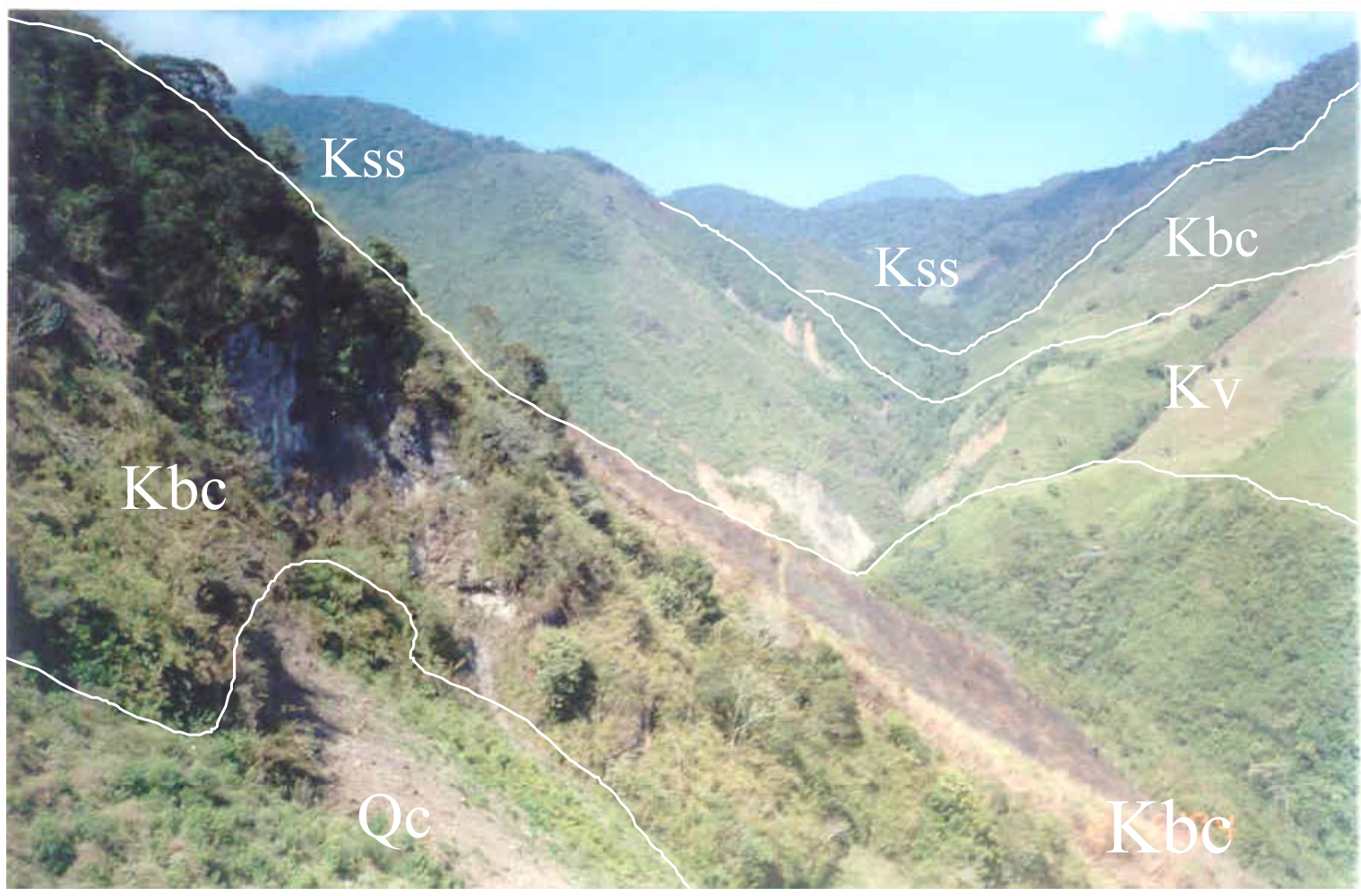

Figura 28. Vista panorâmica do lado norte da área de estudo, apresentando as estruturas rochosas.

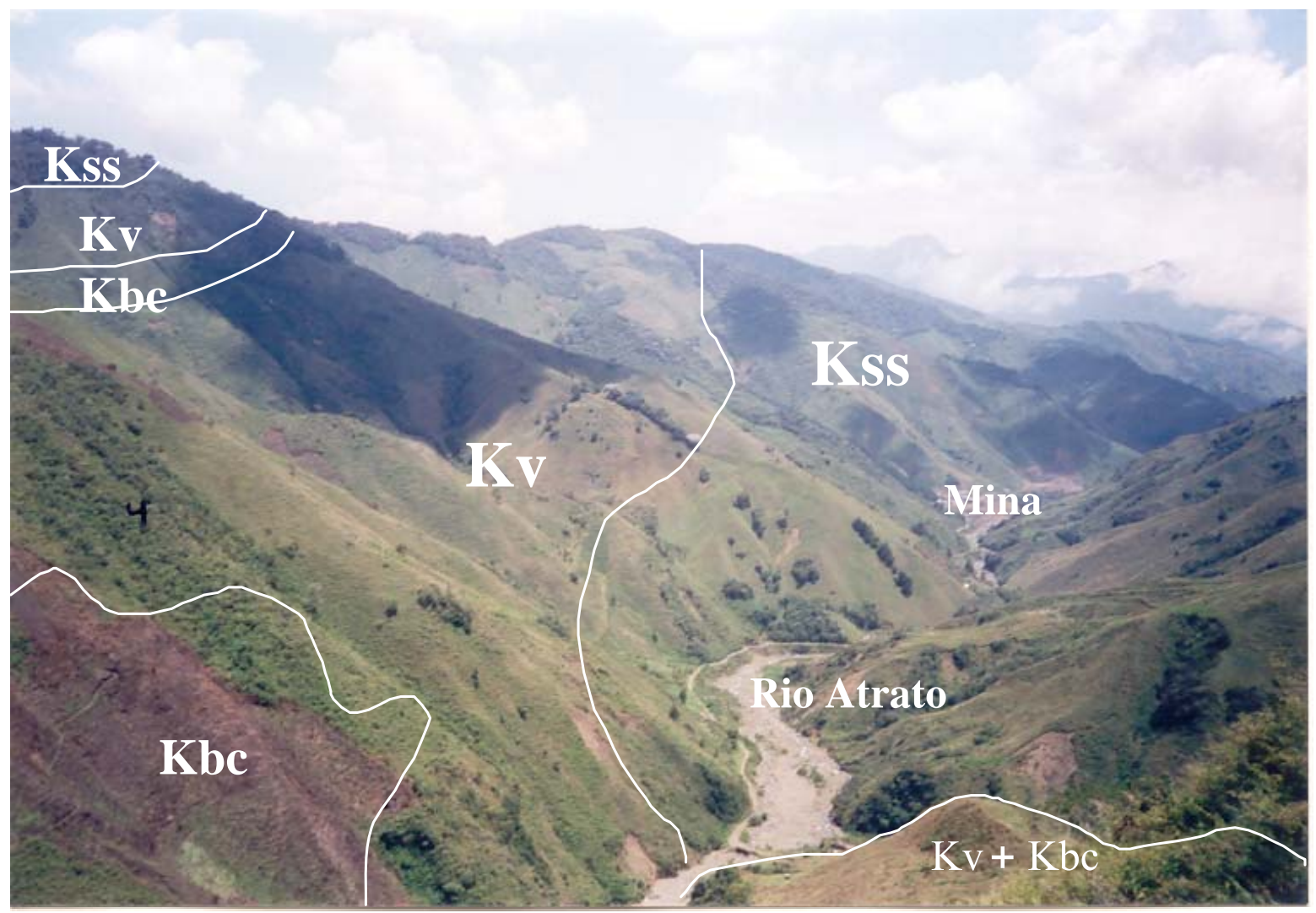

Figura 29. Vista panorâmica do lado sul da área de estudo. 


\subsection{Avaliador geológico de prospecção.}

Os mapas das anomalias geoquímicas da área de estudo estão apresentados na Figura 30 (a,b,c,d) e são o resultado de estudos de exploração feitos pela empresa MINER S.A e que foram compilados e digitalizados no "software" DIGER 2.0 e interpolados no "software" SURFER 7.0. No Anexo 2 são apresentados os dados de campo; na primeira e segunda coluna estão a localização da amostra e na terceira coluna os conteúdos em ppm de cada elemento explorador.

Destes mapas podem-se tirar as seguintes conclusões:

- Os menores conteúdos de Au ficam na região entre os pontos com coordenadas: $\left(1^{\prime} 142.000 \mathrm{~N}, 1^{\prime} 102.000 \mathrm{E}\right),\left(1^{\prime} 142.000 \mathrm{~N}, 1^{\prime} 107.000 \mathrm{E}\right)$ e $\left(1^{\prime} 147.000 \mathrm{~N}, 1^{\prime} 102.000 \mathrm{E}\right)$, $(1 ' 147.000 \mathrm{~N}, 1$ '107.000E)

- Os menores conteúdos de Ag ficam na região entre os pontos com coordenadas: $\left(1^{\prime} 140.000 \mathrm{~N}, 1^{\prime} 102.000 \mathrm{E}\right),\left(1^{\prime} 140.000 \mathrm{~N}, 1^{\prime} 105.000 \mathrm{E}\right)$ e $\left(1^{\prime} 145.000 \mathrm{~N}, 1^{\prime} 102.000 \mathrm{E}\right)$, $(1 ’ 145.000 \mathrm{~N}, 1$ '105.000E)

- Os menores conteúdos de Pb ficam na região entre os pontos com coordenadas: $\left(1^{\prime} 141.000 \mathrm{~N}, 1^{\prime} 103.000 \mathrm{E}\right),\left(1^{\prime} 141.000 \mathrm{~N}, 1^{\prime} 107.000 \mathrm{E}\right)$ e $\left(1^{\prime} 150.000 \mathrm{~N}, 1^{\prime} 103.000 \mathrm{E}\right)$, (1'150.000N, 1'107.000E).

- Os menores conteúdos de $\mathrm{Zn}$ ficam na região entre os pontos com coordenadas: $\left(1^{\prime} 141.000 \mathrm{~N}, 1^{\prime} 103.000 \mathrm{E}\right),\left(1^{\prime} 141.000 \mathrm{~N}, 1^{\prime} 105.000 \mathrm{E}\right)$ e $\left(1^{\prime} 146.000 \mathrm{~N}, 1^{\prime} 103.000 \mathrm{E}\right)$, $\left(1^{\prime} 146.000 \mathrm{~N}, 1\right.$ '105.000E)

- A região de menor quantidade em ppm de elementos exploradores pode se limitar pelo quadrângulo de pontos: (1'142.000N, 1'103.000), (1'142.000N, 1'104.500E) e $(1 ' 147.000 \mathrm{~N}, 1$ '103.000E), (1'147.000N, 1'104.500E)

Depois de definir estas condições geoquímicas da área de estudo, que garantem inicialmente que a barragem não será construída num local que tenha conteúdos importantes de minério, definiu-se claramente uma área de estudo resultante quase 4 vezes menor.

A seguir se realizou uma visita à área e se identificaram três locais para os quais será aplicado o método de análise hierárquica. 
Conteúdo de Ouro em sedimentos ativos (ppm)

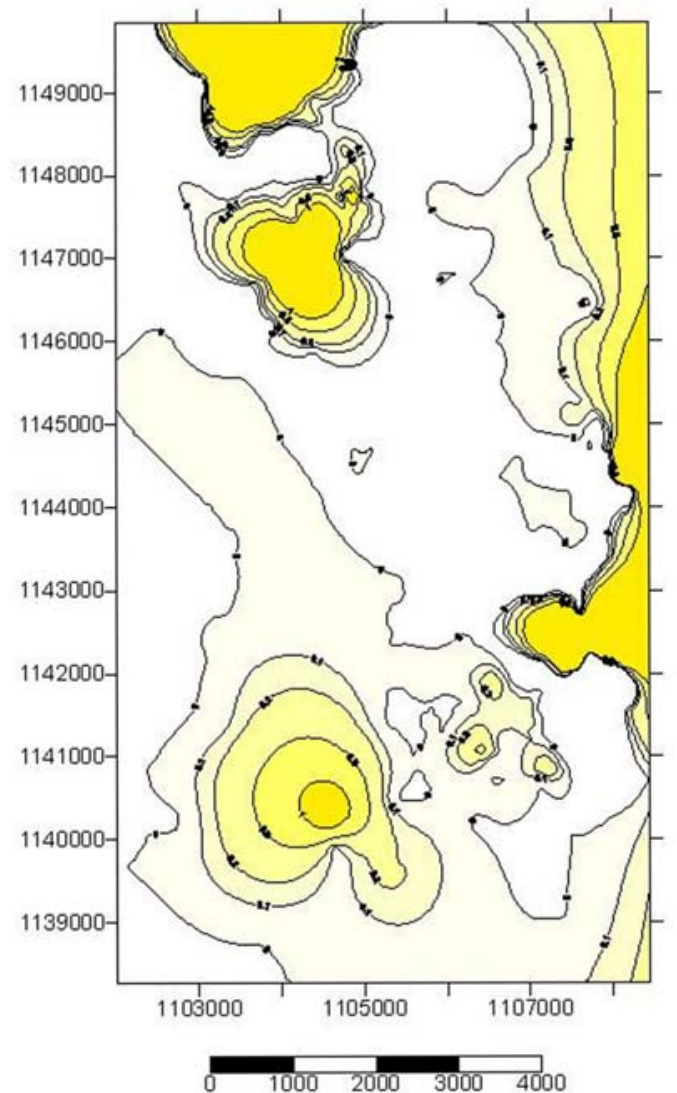

(a)

Conteúdo de Chumbo em sedimentos ativos (ppm)

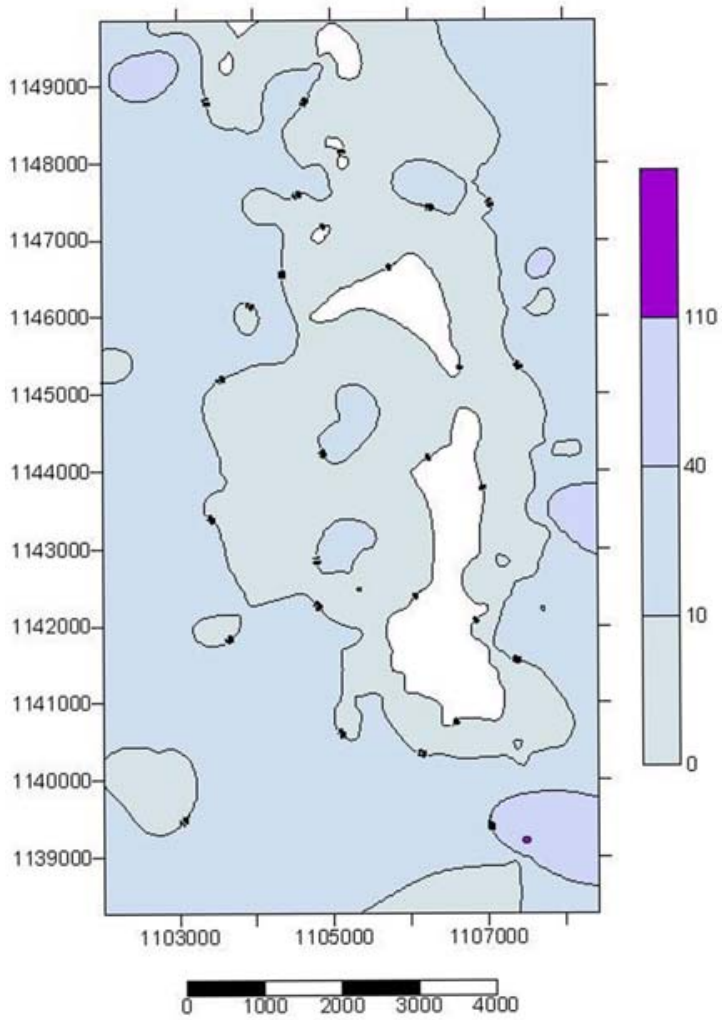

(c)
Conteúdo de Prata em sedimentos ativos (ppm)

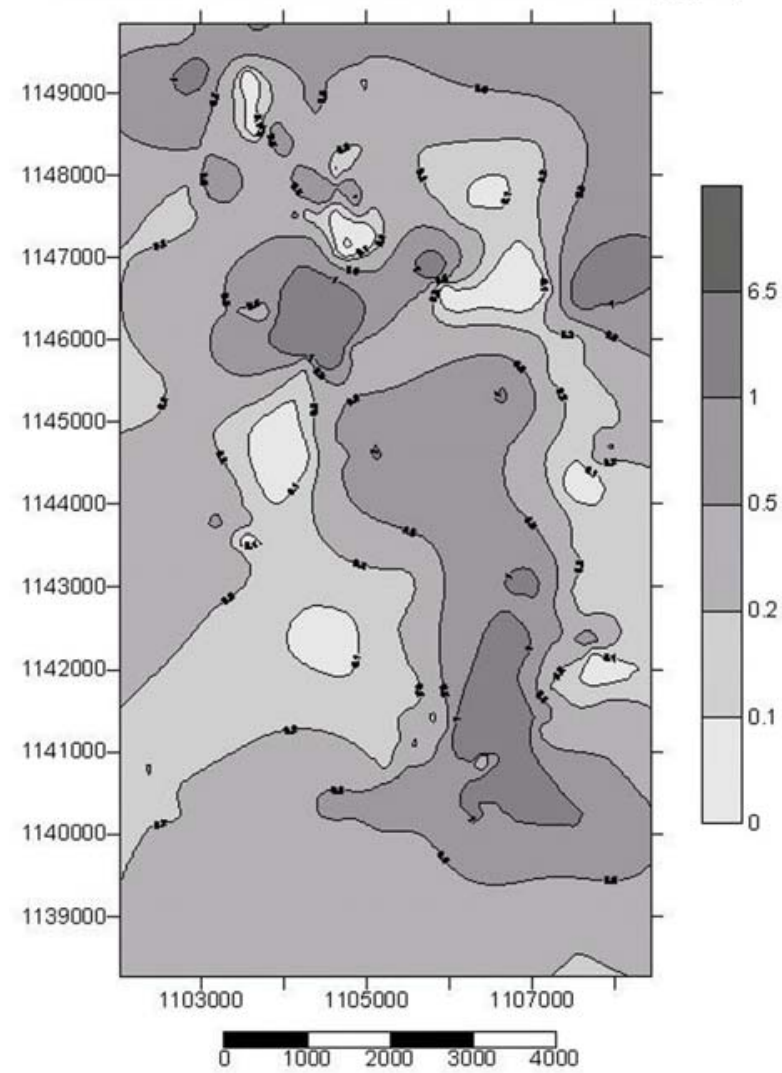

(b)

Conteúdo de Zinco em sedimentos ativos (ppm)

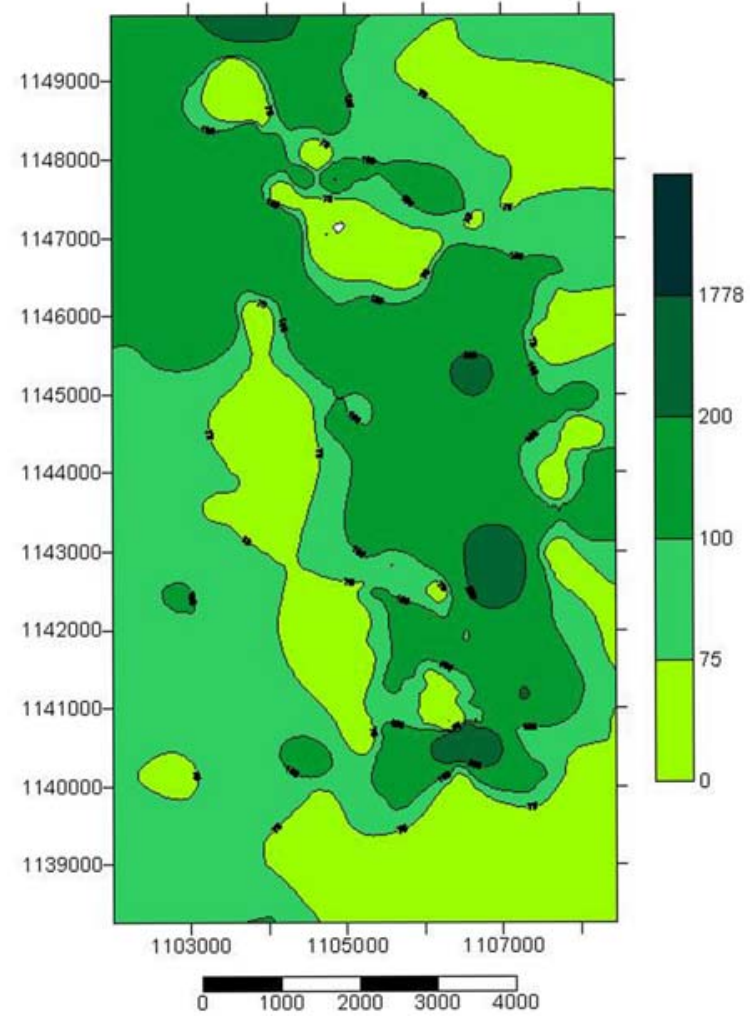

(d)

Figura 30. Geoquímica da zona de estudo: (a) Ouro, (b) Prata, (c) Chumbo, (d) Zinco. 


\subsection{ALTERNATIVAS DE LOCAL.}

Para os três locais selecionados no item 7.3 foram coletadas as informações relativas aos indicadores propostos na.Tabela 17.

\subsubsection{Local 1.}

- Localização:

$1 ' 146.750 \mathrm{~N}$

1'104.100E

Fica na margem esquerda do rio Atrato, aproximadamente a 100 metros do leito entre as cotas 1865 e 1930 acima do mar (Figura 31).

- Formas e declividade: Encosta de topo semianguloso a ondulado, de altitude $65 \mathrm{~m} \mathrm{e}$ amplitude de $120 \mathrm{~m}$, declividade principal na direção $\mathrm{N}-\mathrm{W} 54 \%\left(28^{\circ}\right)$. Os perfis transversais apresentam associação de encostas com perfil convexo de declividades que variam de 27 a $37^{\circ}$ nos extremos, subordinadas a superfícies com perfil côncavo com declividades que variam de $9^{\circ}$ a $15^{\circ}$ nas direções N-E e S-W. Três canais de drenagem subdentrítico conformam a unidade, com vazões que variam de $6 \mathrm{~L} / \mathrm{s}$ (verão) a $90 \mathrm{~L} / \mathrm{s}$ (períodos de chuva). Sua forma geral é uma bacia que capta todas as águas originadas no topo.

- Litologia: A unidade é composta por rochas cretáceas sedimentares; na zona de encostas, por conglomerados, e na base da bacia, por materiais transportados do topo (coluvião). Pelas características morfológicas, os materiais inconsolidados estão medianamente evoluídos nas encostas, apresentando três horizontes: 0,2 $\mathrm{m}$ de solo orgânico, $4 \mathrm{~m}$ de solo residual jovem com fragmentos angulosos mediana a altamente intemperizados, e um terceiro horizonte saprolítico com mais de $4 \mathrm{~m}$ de espessura. No contato coluvião-encosta afloram lutitas e "chert" de cor preta, orientados $\mathrm{N}-35^{\circ} \mathrm{W}$. O coluvião apresenta 3 horizontes: 0,1 m de material orgânico de cor café escuro; $0,6 \mathrm{~m}$ de solo residual jovem de areias grossas, cor café amarelo, pedregulhos angulosos e cantos rochosos angulosos; 0,3 $\mathrm{m}$ composto por capa de origem orgânica cor preta; e um último horizonte de 2,5 $\mathrm{m}$ de solo residual jovem conformado por fragmentos de pedregulhos angulosos e cantos angulosos rochosos medianamente meteorizados com diâmetros de $7 \mathrm{~cm}$ a $25 \mathrm{~cm}$ de diâmetro em seu eixo maior. Apresentam-se fragmentos de rocha vulcânica (vulcânica 
porfirítica) provenientes das encostas superiores, altamente meteorizados. Os níveis de água variam de 1,9 a 2,0 m nesta zona.

- Profundidade do substrato rochoso: $>20 \mathrm{~m}$

- Resistência: conglomerado meterorizado: $12 \mathrm{MPa}$ (rocha fraca a medianamente resistente)

- Textura: Pela análise granulométrica e pelos limites de Atterberg, o material inconsolodado apresenta textura de pedregulho siltoso (GM) (55\%), areia siltosa (SM) (25\%) e silte de baixa compressibilidade (ML) (20\%).

- Variação vertical: Homogêneo contínuo nas encostas (predominante), e heterogêneo contínuo na base da bacia.

- Tipo de depósito: solo residual jovem (pouco evoluído pedológica e morfologicamente (predominante)) nas encostas e coluvião na base.

- Profundidade da zona saturada: nas encostas $<2 \mathrm{~m}$, no coluvião $>6 \mathrm{~m}$.

- Risco de poluição: Probabilidade de ocorrência: 3. Magnitude da poluição quando ocorre: 5. Fatores de mitigação reduzindo os potenciais impactos quando a poluição ocorre: 4. Risco de poluição $=3,75$. Baixo risco de poluição.

- Unidades produtivas e de uso intensivo: não se têm unidades produtivas de uso contínuo.

- Unidades habitacionais: duas unidades habitacionais no local.

- Unidades de reflorestamento: não há. Unidades de pastagem: $150.000 \mathrm{~m}^{2}$. Unidades de agricultura: $10.075 \mathrm{~m}^{2}$. Área total de unidades de pastagem e agricultura: $160.075 \mathrm{~m}^{2}$.

- Altura da barragem com alteamentos: aproximadamente $27 \mathrm{~m}$

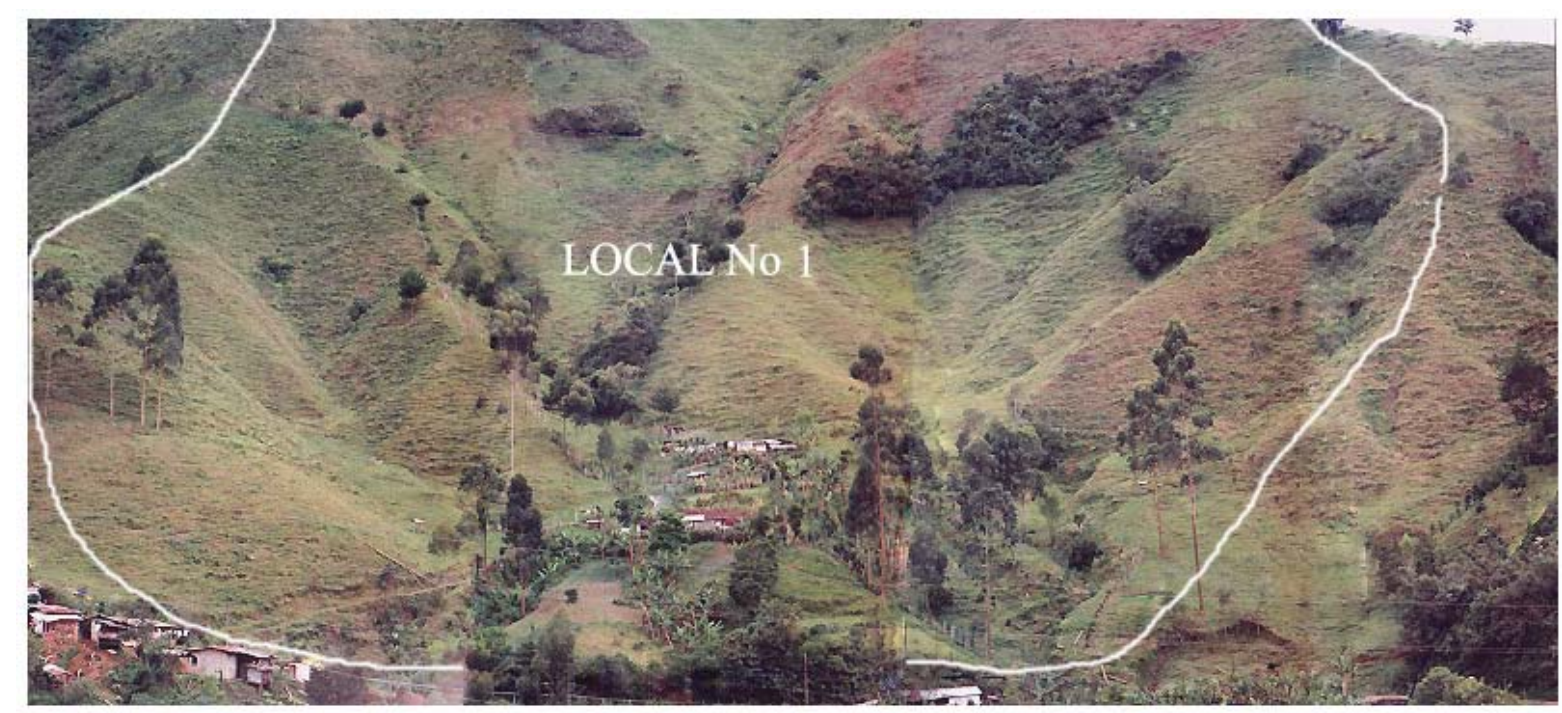

Figura 31. Local No 1. 
- Volumes de material.

Na Tabela 20 são apresentados os volumes de material na construção da barragem e de armazenamento de rejeitos. A Figura 32 mostra a seção típica do local 1.

No estudo preliminar foram utilizadas plantas na escala 1:5000 com curvas de nível a cada 5 metros. Os cálculos de volume foram feitos em seções do local a cada 10 metros.

Para os ângulos de inclinação dos taludes da barragem, adotaram-se as declividades das barragens existentes. (1:1,5 à jusante e 1:1,0 à montante). A largura da crista é de $4 \mathrm{~m}$.

A construção da barragem será feita com o material escavado do mesmo local, o material de decapeamento vai ser utilizado na restauração dos taludes de jusante da barragem.

O tempo de vida útil foi calculado para o enchimento do dique de arranque da barragem (sem alteamentos), com uma produção anual de rejeitos de 70.000 ton, com uma densidade média de 2 ton $/ \mathrm{m}^{3}$ para os rejeitos.

Tabela 20. Volumes de materiais na construção da barragem no local 1.

\begin{tabular}{|c|c|c|c|c|c|}
\hline $\begin{array}{c}\text { Área de operação da } \\
\left.\text { barragem }\left(\mathrm{m}^{2} \times 10^{3}\right)\right)\end{array}$ & $\begin{array}{c}\text { Máxima altura do } \\
\text { dique inicial }(\mathrm{m})\end{array}$ & $\begin{array}{c}\text { Armazenamento de } \\
\text { rejeitos na primeira } \\
\text { etapa }\left(\mathrm{m}^{3} \times 10^{3}\right)\end{array}$ & $\begin{array}{c}\text { Tempo de } \\
\text { vida útil } \\
(\text { anos })\end{array}$ & $\begin{array}{c}\text { Corpo do dique de } \\
\text { arranque }\left(\mathrm{m}^{3} \times 10^{3}\right)\end{array}$ & $\begin{array}{c}\text { Total movimento } \\
\text { de terra }\left(\mathrm{m}^{3} \times 10^{3}\right)\end{array}$ \\
\hline 51 & 12 & 82 & 2,3 & 60 & 67,6 \\
\hline
\end{tabular}

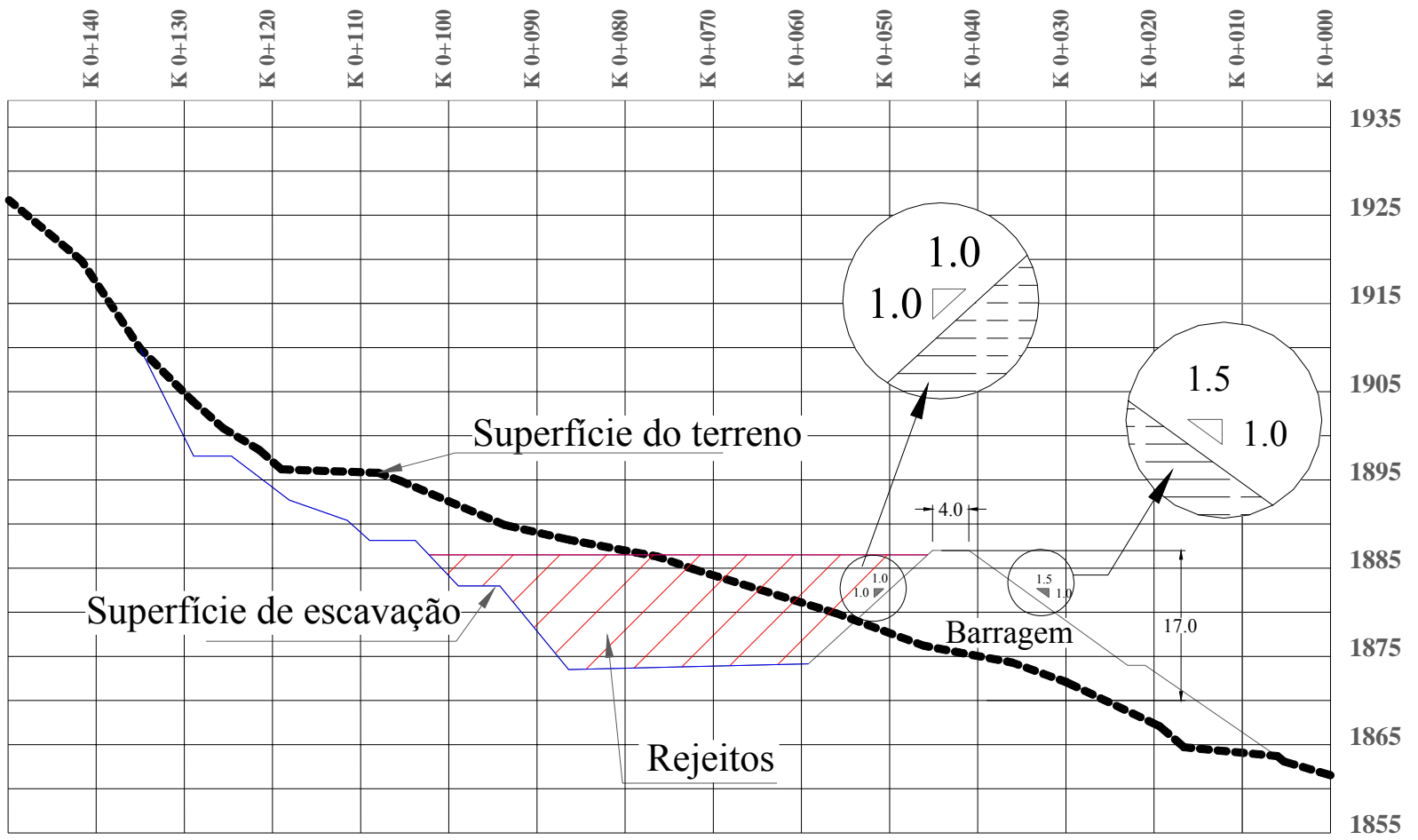

Figura 32. Perfil local No 1. 


\subsubsection{Local 2.}

- Localização:

$1^{\prime} 145.800 \mathrm{~N}$

$1 ' 103.450 \mathrm{E}$

Fica na margem direita do rio Atrato, próximo ao rio, entre as cotas 1770 a 1850 acima do mar (Figura 33).

- Formas e declividade: Encosta de topo levemente arredondado, de altitude $90 \mathrm{~m} \mathrm{e}$ amplitude de $220 \mathrm{~m}$, declividade com direção S-E 40\% $\left(22^{\circ}\right)$, as encostas de perfil convexo subordinadas a perfis côncavos. O perfil transversal apresenta uma superfície levemente inclinada de 5\% $\left(3^{\circ}\right)$ com direção S-W. Apresenta dois canais de drenagem, um retilíneo e outro subdentrítico com vazões não muito significativas $(<5 \mathrm{~L} / \mathrm{s})$.

- Litologia: A unidade esta composta por rochas cretáceas sedimentares, arenitos sob lutitas em toda a zona de encostas. Na base da bacia, depósitos de coluvião misturados com depósitos de aluvião por efeitos de corridas de massa do rio Atrato. Pelas características morfológicas, nas encostas os materiais inconsolidados estão medianamente evoluídos, apresentando quatro horizontes: $0,2 \mathrm{~m}$ de solo orgânico, $0,5 \mathrm{~m}$ de solo residual maduro, solo residual jovem de 1,8 $\mathrm{m}$ de espessura e um horizonte de saprolito com mais de $4 \mathrm{~m}$ de espessura. Nas partes baixas, o solo está conformado por uma mistura de materiais transportados pelo rio e outros depositados pelos movimentos de massa das encostas, com grande quantidade de rochas arredondadas de diâmetro entre 20 e $50 \mathrm{~cm}$, em matriz de arenitos argilosos de grão fino.

- Profundidade: do substrato rochoso: $>10 \mathrm{~m}$ nas encostas, e material quaternário na bacia.

- Resistência: Arenito meterorizado: $24 \mathrm{MPa}$ (rocha fraca a medianamente resistente)

- Textura: Pela análise granulométrica dos materiais inconsolidados das encostas, apresenta características texturais de areia siltosa (SM).

- Variação vertical: Homogêneo contínuo na encosta (predominante), heterogêneo descontínuo na base da bacia.

- Tipo de depósito: solo residual jovem (pouco evoluído pedológica e morfologicamente) nas encostas e na base mistura aluvião (no limite com o rio) - coluvião (predominante).

- Profundidade da zona saturada: nas encostas $<2 \mathrm{~m}$, na parte baixa $<4 \mathrm{~m}$.

- Risco de poluição: Probabilidade de ocorrência: 5. Magnitude da poluição quando ocorre: 5. Fatores de mitigação reduzindo os potenciais impactos quando a poluição ocorre: 5 . Risco de poluição = 5,0. Médio risco de poluição. 
- Unidades produtivas e de uso intensivo: há uma unidade produtiva (leite, queijo e seus derivados) de $12.600 \mathrm{~m}^{2}$.

- Unidades habitacionais: quatro unidades habitacionais no local.

- Unidades de reflorestamento: não há. Unidades de pastagem: $90.000 \mathrm{~m}^{2}$. Unidades de agricultura: não há. Área total de unidades de pastagem, agricultura e reflorestamento: $90.000 \mathrm{~m}^{2}$.

- Altura da barragem com alteamentos: aproximadamente $39 \mathrm{~m}$

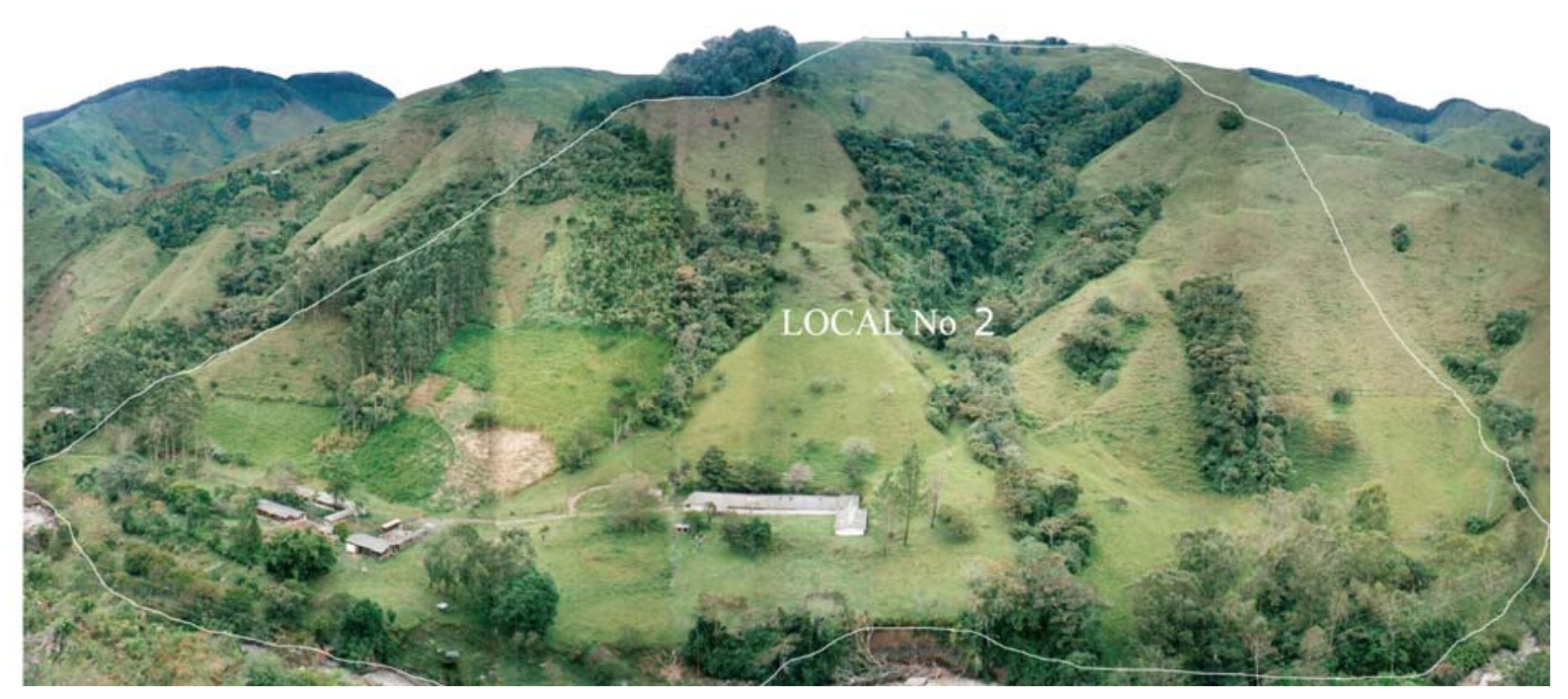

Figura 33. Local No 2.

- Volumes de material.

$\mathrm{Na}$ Tabela 21 estão apresentados os volumes de material na construção da barragem e de armazenamento de rejeitos. A Figura 34 apresenta a seção típica do local 2.

No estudo preliminar foram utilizadas plantas na escala 1:5000 com curvas de nível a cada 5 metros. Os cálculos de volume foram feitos em seções do local a cada 10 metros.

Para os ângulos de inclinação dos taludes da barragem, adotaram-se as declividades das barragens existentes. (1:1,5 à jusante e 1:1,0 à montante). A largura da crista é de $4 \mathrm{~m}$.

A construção da barragem será feita com o material escavado do mesmo local e quando for necessário se utilizará material de empréstimo que fica a $1 \mathrm{Km}$ do local. $\mathrm{O}$ material de decapeamento vai ser utilizado na restauração dos taludes de jusante da barragem.

O tempo de vida útil foi calculado para o enchimento do dique de arranque da barragem (sem alteamentos), com uma produção anual de rejeitos de 70.000 ton com uma densidade média de 2 ton $/ \mathrm{m}^{3}$ para os rejeitos. 
Tabela 21. Volumes de materiais na construção da barragem no local 2.

\begin{tabular}{|c|c|c|c|c|c|}
\hline $\begin{array}{c}\text { Área de operação da } \\
\left.\text { barragem }\left(\mathrm{m}^{2} \times 10^{3}\right)\right)\end{array}$ & $\begin{array}{c}\text { Máxima altura do } \\
\text { dique inicial }(\mathrm{m})\end{array}$ & $\begin{array}{c}\text { Armazenamento de } \\
\text { rejeitos na primeira } \\
\text { etapa }\left(\mathrm{m}^{3} \times 10^{3}\right)\end{array}$ & $\begin{array}{c}\text { Tempo de } \\
\text { vida útil } \\
(\text { anos })\end{array}$ & $\begin{array}{c}\text { Corpo do dique de } \\
\text { arranque }\left(\mathrm{m}^{3} \times 10^{3}\right)\end{array}$ & $\begin{array}{c}\text { Total movimento } \\
\text { de terra }\left(\mathrm{m}^{3} \times 10^{3}\right)\end{array}$ \\
\hline 78 & 20 & 111 & 3,2 & 54 & 60,3 \\
\hline
\end{tabular}

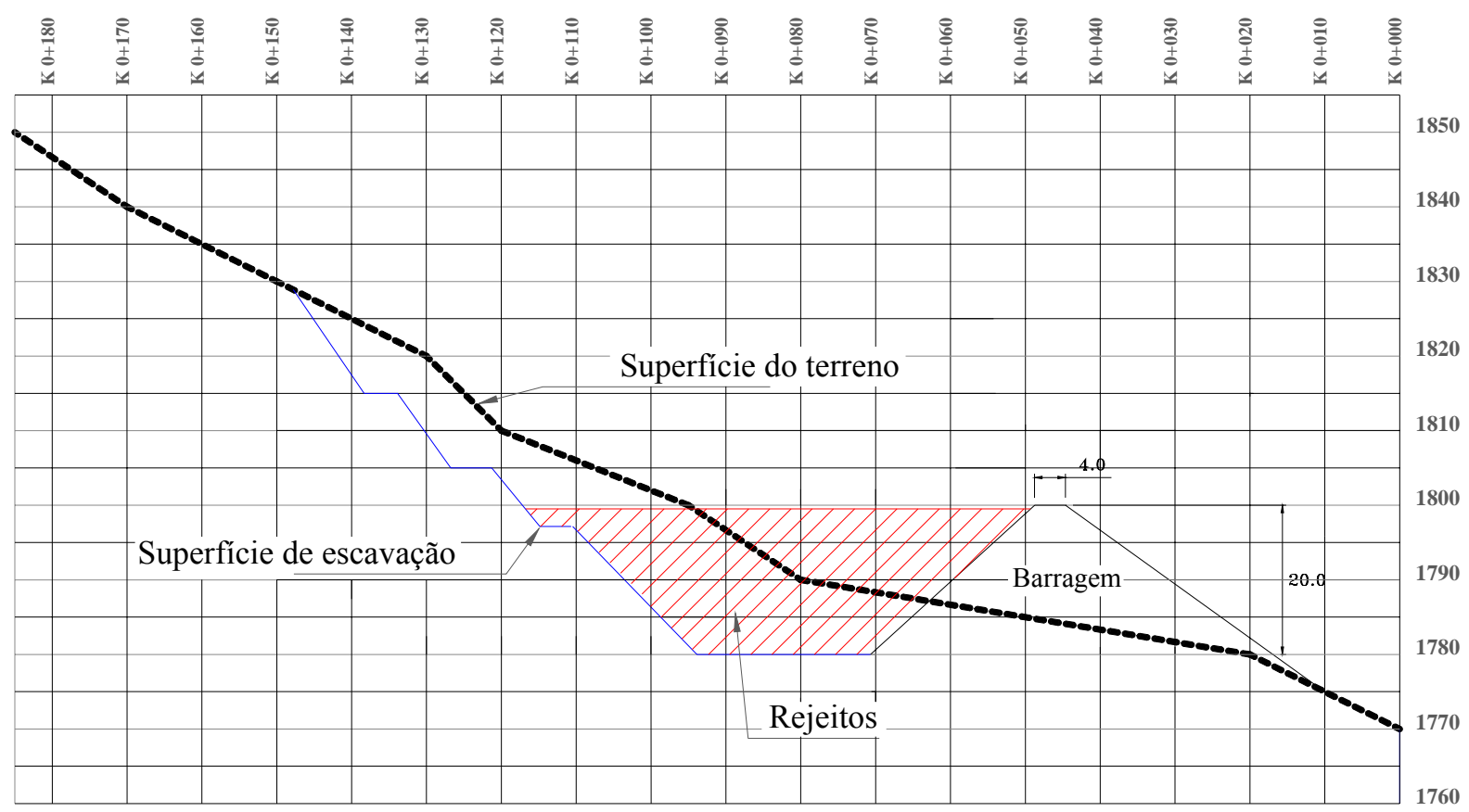

Figura 34. Perfil local No 2.

\subsubsection{Local 3.}

- Localização:

$1 ' 145.000 \mathrm{~N}$.

$1 ' 103.500 \mathrm{E}$

Fica na margem direita do rio Atrato, próximo ao rio, entre as cotas 1730 a 1800 acima do mar (Figura 35).

- Formas e declividade: Encosta de topo levemente anguloso, de altitude $80 \mathrm{~m}$ e amplitude de $245 \mathrm{~m}$, declividade com direção S-E $31 \%\left(17^{\circ}\right)$, encosta com inclinação moderada e perfil côncavos. O perfil transversal apresenta uma superfície levemente inclinada menor de $5 \%\left(3^{\circ}\right)$ com direção $\mathrm{S}-\mathrm{W}$, é uma planície de aproximadamente $400 \mathrm{~m}$ de comprimento por $30 \mathrm{~m}$ de largura. Não apresenta canais de drenagem.

- Litologia: A unidade está composta por rochas cretáceas sedimentares, arenitos na zona de encostas e na base da encosta, um grande depósito produto de movimentos de massa das encostas. Pelas características morfológicas, nas encostas os materiais inconsolidados 
estão relativamente evoluídos, apresentando quatro horizontes: $0,3 \mathrm{~m}$ de solo orgânico, 0,8 $\mathrm{m}$ de solo residual maduro, solo residual jovem de $4 \mathrm{~m}$ e um horizonte de saprolito mais espesso que $6 \mathrm{~m}$. Nas partes baixas, o material inconsolidado apresenta um coluvião homogêneo; na base do coluvião aparecem depósitos de aluvião, composto por rochas de grande diâmetro (> $5 \mathrm{~m}$ ), arredondadas com matriz areno-argilosa.

- Profundidade: do substrato rochoso: $>15 \mathrm{~m}$ nas encostas, e material quaternário na bacia.

- Resistência: Arenito meterorizado: $24 \mathrm{MPa}$ (rocha fraca a medianamente resistente)

- Textura: Pela análise granulométrica dos materiais inconsolidados das encostas, apresenta características texturais de areia siltosa (SM).

- Variação vertical: Homogêneo contínuo na encosta e heterogêneo contínuo na base da bacia (predominante).

- Tipo de depósito: solo residual jovem (pouco evoluído pedológica e morfologicamente) nas encostas e na base aluvião (no limite com o rio, predominante) - coluvião.

- Profundidade da zona saturada: nas encostas $<4 \mathrm{~m}$; na zona baixa, apresenta zonas úmidas na zona sul; pouca declividade faz que não seja bem drenado.

- Risco de poluição: Probabilidade de ocorrência: 3. Magnitude da poluição quando ocorre: 5. Fatores de mitigação reduzindo os potenciais impactos quando a poluição ocorre: 4 . Risco de poluição $=3,75$. Baixo risco de poluição.

- Unidades produtivas e de uso intensivo: não há.

- Unidades habitacionais: não há.

- Unidades de reflorestamento: não há. Unidades de pastagem: $150.500 \mathrm{~m}^{2}$. Unidades de agricultura: não há. Área total de unidades de pastagem, agricultura e reflorestamento: $150.500 \mathrm{~m}^{2}$.

- Altura da barragem com alteamentos: aproximadamente $48 \mathrm{~m}$

- Volumes de material.

$\mathrm{Na}$ Tabela 22 estão apresentados os volumes de material na construção da barragem e de armazenamento de rejeitos. A Figura 36 mostra a seção típica do local . Utiliza-se o talude natural sem construção de barragem nos primeiros 150 metros N-S do local; nos outros 250 metros é necessária a construção dos 7 metros finais, até a crista da barragem. É importante ressaltar que o material escavado é maior do que o material usado na construção da barragem, podendo-se armazenar para futuros alteamentos.

No estudo preliminar foram utilizadas plantas na escala 1:5000 com curvas de nível a cada 5 metros. Os cálculos de volume foram feitos em seções do local a cada 10 metros. 


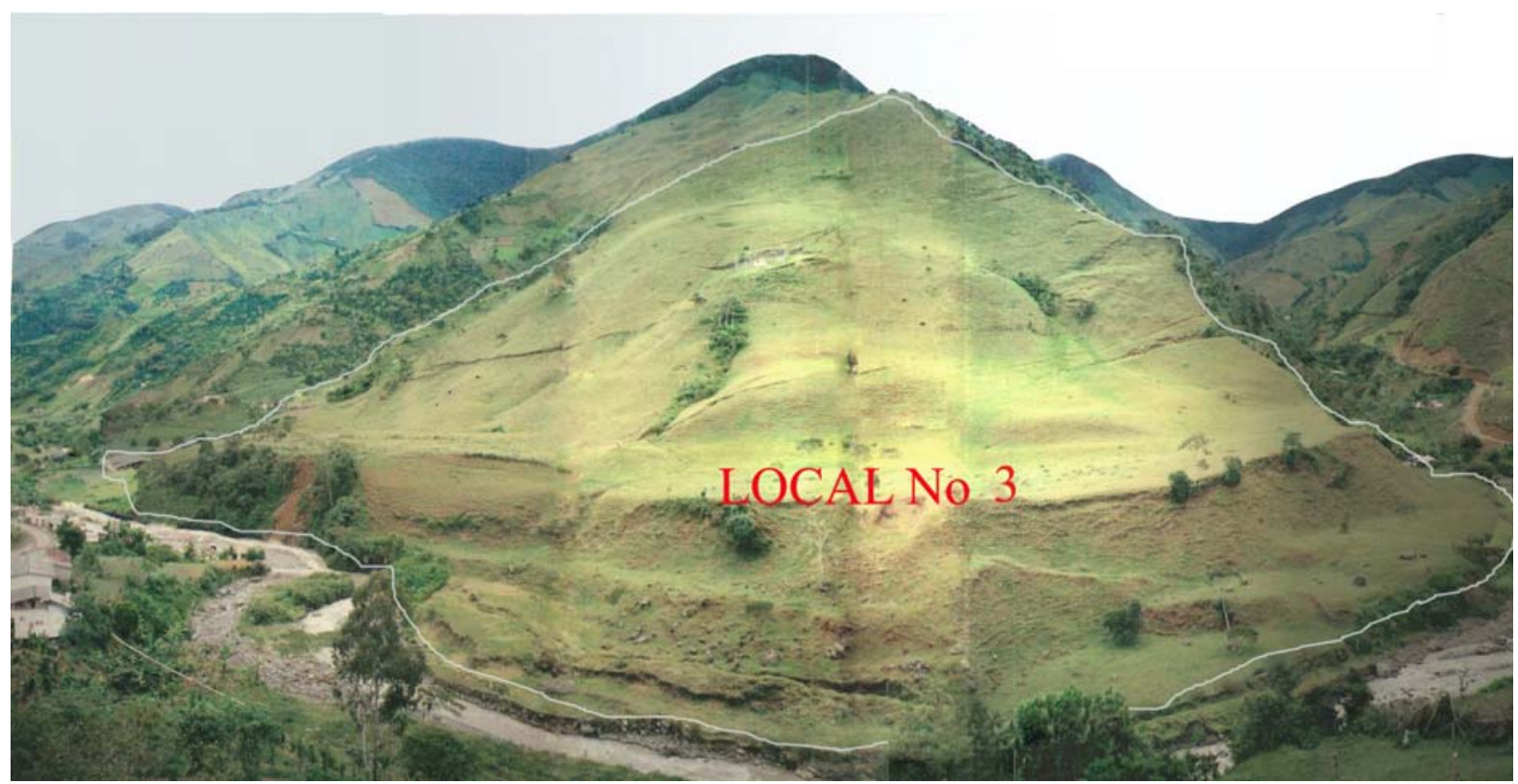

Figura 35. Local No 3.

Para os ângulos de inclinação dos taludes da barragem, adotaram-se as declividades de 1:1,1 à jusante e 1:2 à montante). A largura da crista é de $4 \mathrm{~m}$.

O tempo de vida foi calculado para o enchimento do dique de arranque da barragem (sem alteamentos), com uma produção anual de rejeitos de 70.000 ton, com uma densidade média de 2 ton $/ \mathrm{m}^{3}$ para os rejeitos.

Tabela 22. Volumes de materiais na construção da barragem no local 3.

\begin{tabular}{|c|c|c|c|c|}
\hline $\begin{array}{c}\text { Área de operação da } \\
\left.\text { barragem }\left(\mathrm{m}^{2} \times 10^{3}\right)\right)\end{array}$ & $\begin{array}{c}\text { Máxima altura do } \\
\text { dique inicial }(\mathrm{m})\end{array}$ & $\begin{array}{c}\text { Armazenamento de rejeitos } \\
\text { na primeira etapa }\left(\mathrm{m}^{3} \times 10^{3}\right)\end{array}$ & $\begin{array}{c}\text { Tempo de vida útil } \\
(\text { anos })\end{array}$ & $\begin{array}{c}\text { Corpo do dique de } \\
\text { arranque }\left(\mathrm{m}^{3} \times 10^{3}\right)\end{array}$ \\
\hline 90 & 20 & 312 & 9,0 & 296,8 \\
\hline
\end{tabular}

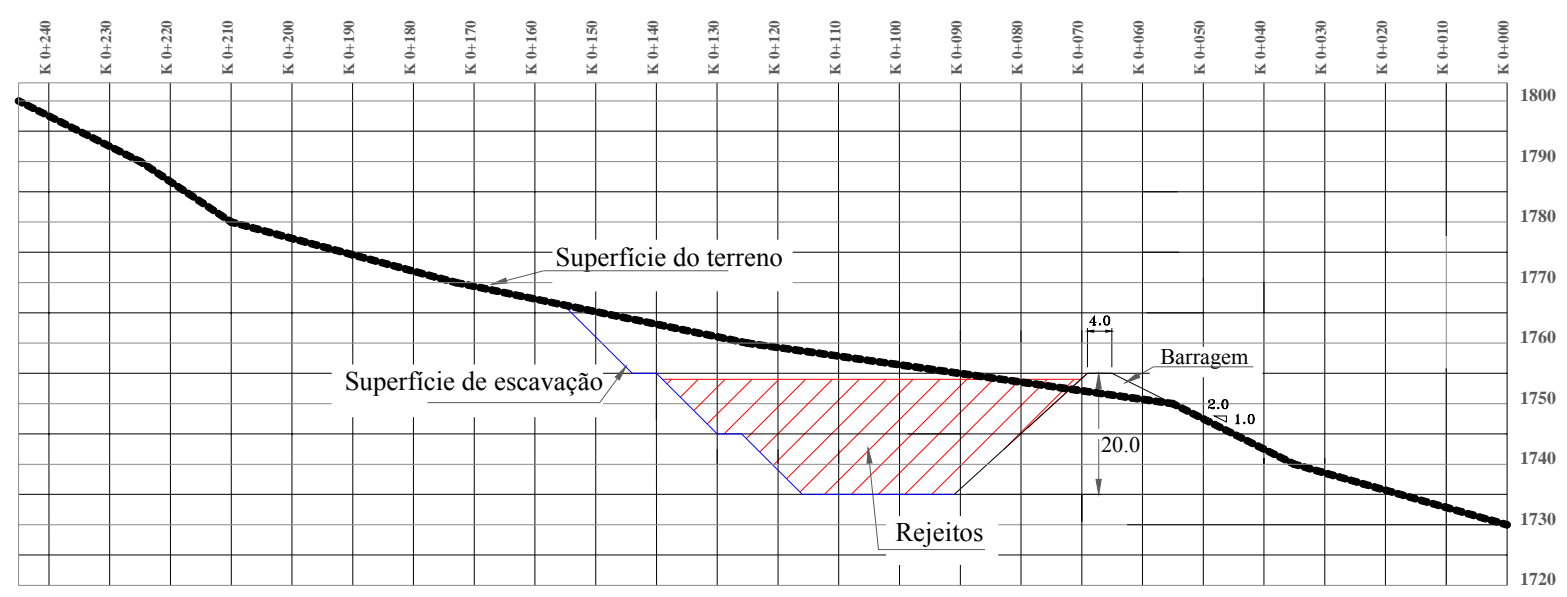

Figura 36. Perfil local No 3. 


\section{APLICAÇÃO DO MÉTODO DE ANÁLISE HIERÁRQUICA NO ESTUDO DE CASO}

Como visto no Capítulo 6, definiram-se indicadores para a seleção de locais de barragens de rejeitos, reduziu-se a área de estudo após a prospecção geoquímica, selecionaram-se três áreas alternativas, e obtiveram-se as informações necessárias a respeito de cada área alternativa. Neste capítulo será aplicado o método de análise hierárquica para auxiliar na tomada de decisões sobre o local mais apropriado para a construção de uma barragem de rejeitos na área de estudo localizada no município do Carmen de Atrato, Colômbia.

A aplicação do AHP não só sugere um local para a construção da barragem de rejeitos, como também permite uma visão geral do problema para o tomador de decisões. Os pesos das alternativas obtidos pelo AHP são a seguir confrontados com os custos.

\subsection{Definição de critérios e sub critérios.}

No estudo de caso, são dois os elementos que vão ser avaliados segundo a quantidade de informações disponíveis sobre os locais, quais sejam: custos e menor impacto ambiental.

O objetivo da estrutura hierárquica é avaliar o local que gera o menor impacto ambiental na zona, assim o resultado da avaliação gera um vetor de pesos de importância, onde o maior valor é o local que gera o menor impacto ambiental. Os custos são avaliados fora da estrutura hierárquica (ver item 8.7) e confrontados com ela posteriormente.

Os critérios avaliados, que são as ocorrências que geram potencialmente impacto ambiental, foram definidos como: Implantação da Barragem, Ruptura da Barragem e Transporte de Rejeitos ao Local. Esses critérios estão divididos em sub-critérios, que são os elementos do meio ambiente que recebem potencialmente impacto: fauna, flora, ocupação humana, água, ar e solo. No último nível da hierarquia estão as alternativas de local.

Por simples que pareça a hierarquia, ele envolve todos os indicadores definidos na Tabela 17, além de estudos realizados na zona a nível regional e local, como mostra a Tabela 23: 
Tabela 23. Relação de critérios e sub-critérios com indicadores propostos.

\begin{tabular}{|c|c|c|}
\hline Cri & Sub-critérios & Relação com indicadores da Tabela 17 e estudos da região \\
\hline \multirow{6}{*}{$\begin{array}{l}\text { Ruptura da barragem } \\
\text { (impactos à jusante por } \\
\text { possível ruptura da } \\
\text { barragem) } \\
\text { Objetivo: local com } \\
\text { menor impacto pela } \\
\text { eventual ruptura. }\end{array}$} & Flora & $\begin{array}{l}\text { Unidades de parques nacionais, ecossistemas sensíveis } \\
\text { Unidades de vegetação nativa (estudos regionais) }\end{array}$ \\
\hline & Fauna & $\begin{array}{l}\text { Unidades de parques nacionais, ecossistemas sensíveis } \\
\text { (estudos regionais) }\end{array}$ \\
\hline & $\begin{array}{l}\text { Ocupação } \\
\text { humana }\end{array}$ & $\begin{array}{l}\text { Unidades produtivas e de uso intensivo, Unidades } \\
\text { habitacionais, Unidades de reflorestamento, pastagem e } \\
\text { agricultura. (estudos locais e regionais) }\end{array}$ \\
\hline & Água & Interferências com recursos hídricos (estudos regionais) \\
\hline & $\mathrm{Ar}$ & Impactos na qualidade do ar (estudos locais) \\
\hline & Solo & Relevo e impactos no uso do solo (estudos locais e regionais) \\
\hline \multirow{6}{*}{$\begin{array}{l}\text { Transporte de rejeitos } \\
\text { ao local (impactos por } \\
\text { possíveis rupturas de } \\
\text { tubulações no } \\
\text { transporte de rejeitos } \\
\text { ao local da barragem) } \\
\text { Objetivo: Local que } \\
\text { gere menor impacto no } \\
\text { transporte de rejeitos }\end{array}$} & Flora & $\begin{array}{l}\text { Unidades de parques nacionais, ecossistemas sensíveis } \\
\text { Unidades de vegetação nativa (estudos regionais) }\end{array}$ \\
\hline & Fauna & Ecossistemas sensíveis (estudos locais) \\
\hline & $\begin{array}{l}\text { Ocupação } \\
\text { humana }\end{array}$ & $\begin{array}{l}\text { Unidades produtivas e de uso intensivo, Unidades } \\
\text { habitacionais, Unidades de reflorestamento, pastagem e } \\
\text { agricultura. (estudos locais) }\end{array}$ \\
\hline & Água & Interferências com recursos hídricos (estudos locais) \\
\hline & Ar & Possíveis impactos na qualidade do ar (estudos locais) \\
\hline & Solo & Relevo e impactos no uso do solo (estudos locais) \\
\hline \multirow{6}{*}{$\begin{array}{l}\text { Implantação da } \\
\text { barragem (impactos no } \\
\text { local pela implantação } \\
\text { da barragem de rejeitos } \\
\text { e reservatório) } \\
\text { Objetivo: Local que } \\
\text { por sua própria } \\
\text { implantação gere o } \\
\text { menor impacto. }\end{array}$} & Flora & $\begin{array}{l}\text { Unidades de parques nacionais, ecossistemas sensitivos } \\
\text { Unidades de vegetação nativa (estudos regionais) }\end{array}$ \\
\hline & Fauna & ecossistemas sensitivos (estudos locais) \\
\hline & $\begin{array}{l}\text { Ocupação } \\
\text { humana }\end{array}$ & $\begin{array}{l}\text { Unidades produtivas e de uso intensivo, Unidades } \\
\text { habitacionais, Unidades de reflorestamento, pastagem e } \\
\text { agricultura. (estudos locais) }\end{array}$ \\
\hline & Água & $\begin{array}{l}\text { Águas subterrâneas (estudos locais), substrato rochosos, } \\
\text { materiais inconsolidados (estudos locais) }\end{array}$ \\
\hline & Ar & Possíveis impactos na qualidade do ar (estudos locais) \\
\hline & Solo & $\begin{array}{l}\text { Substrato rochoso, materiais inconsolidados, processos, relevo } \\
\text { (estudos locais). }\end{array}$ \\
\hline
\end{tabular}

No estudo de caso se observa que cada local não está necessariamente sujeito ao impacto potencial relativo a todos os sub-critérios, pelas características regionais (como no caso do ar) ou pelas características do próprio local, como mostrado na Tabela 24. 
Tabela 24 Critérios e sub-critérios que vão ser avaliados para o estudo de caso.

\begin{tabular}{|c|c|c|}
\hline Critério & Sub-critério & Descrição para os Locais 1,2 e 3 \\
\hline \multirow{6}{*}{$\begin{array}{l}\text { Ruptura da } \\
\text { barragem }\end{array}$} & Fauna & $\begin{array}{l}\text { O impacto gerado na fauna da drenagem principal (rio Atrato) é igual para } \\
\text { todos os locais e significativo no contexto do problema. }\end{array}$ \\
\hline & Flora & Em caso de ruptura, não há unidades de vegetação nativa afetadas. \\
\hline & $\begin{array}{l}\text { Ocupação } \\
\text { humana }\end{array}$ & $\begin{array}{l}\text { Existem impactos diferenciados para os três locais, sendo maior para o local } 3 \\
\text { por sua proximidade com o município de Carmen de Atrato. }\end{array}$ \\
\hline & Água & O impacto gerado na drenagem principal é igual para os três locais. \\
\hline & Ar & $\begin{array}{l}\text { Pelas condições climáticas da zona de estudo (umidade relativa alta, } \\
\text { velocidade do vento baixa e alta pluviometria), o impacto no ar é igualmente } \\
\text { desprezível para todos os locais. }\end{array}$ \\
\hline & Solo & $\begin{array}{l}\text { Pelas características do relevo e da bacia hidrográfica, o impacto no solo não é } \\
\text { significativo para os três locais; a massa de resíduos escoará pela drenagem. }\end{array}$ \\
\hline \multirow{5}{*}{$\begin{array}{l}\text { Transporte } \\
\text { de rejeitos } \\
\text { ao local }\end{array}$} & Fauna & $\begin{array}{l}\text { O impacto não é significativo, por diferentes motivos: } \\
\text { - o transporte é feito em tubulação por gravidade, que é protegida por } \\
\text { tubulações metálicas quando passa por áreas de pastagem, agricultura ou } \\
\text { reflorestamento. } \\
\text { - Rupturas na tubulação são detectadas e solucionadas imediatamente. } \\
\text { O impacto na fauna e flora, portanto, é igualmente desprezível em todos os } \\
\text { locais. }\end{array}$ \\
\hline & $\begin{array}{l}\text { Ocupação } \\
\text { humana }\end{array}$ & $\begin{array}{l}\text { O impacto é diferenciado para cada local, pela distância da usina de } \\
\text { beneficiamento até a barragem e pela quantidade de moradias que poderiam } \\
\text { ser afetadas por ruptura da tubulação em zonas sem proteção. }\end{array}$ \\
\hline & Água & $\begin{array}{l}\text { O impacto é diferenciado para cada local pela quantidade de cursos de água } \\
\text { afetados se ocorrer ruptura da tubulação. }\end{array}$ \\
\hline & $\mathrm{Ar}$ & Desprezível, pelos mesmos motivos relacionados na ruptura de barragem. \\
\hline & Solo & $\begin{array}{l}\text { O impacto é diferenciado para cada local, em função do comprimento da } \\
\text { tubulação e da distância à usina de beneficiamento. }\end{array}$ \\
\hline \multirow{6}{*}{$\begin{array}{l}\text { Implantação } \\
\text { da barragem } \\
\text { e respectivo } \\
\text { reservatório }\end{array}$} & Fauna & \multirow{2}{*}{$\begin{array}{l}\text { Não há impacto significativo nos locais, pois não há flora e fauna nativas (ver } \\
\text { item 7.4). }\end{array}$} \\
\hline & Flora & \\
\hline & $\begin{array}{l}\text { Ocupação } \\
\text { humana }\end{array}$ & O impacto é diferenciado para cada local, em função da ocupação do solo. \\
\hline & Água & $\begin{array}{l}\text { O impacto é diferenciado para cada local em relação ás águas subterrâneas, } \\
\text { em função da profundidade do lençol freático. }\end{array}$ \\
\hline & $\mathrm{Ar}$ & Desprezível, pelos mesmos motivos relacionados na ruptura de barragem. \\
\hline & Solo & $\begin{array}{l}\text { O impacto é diferenciado para cada local, em função das características do } \\
\text { substrato rochoso. }\end{array}$ \\
\hline
\end{tabular}




\subsection{Hierarquização do problema.}

A hierarquia foi baseada na lista de critérios e sub-critérios propostos na Tabela 24 e está apresentada na Figura 37.

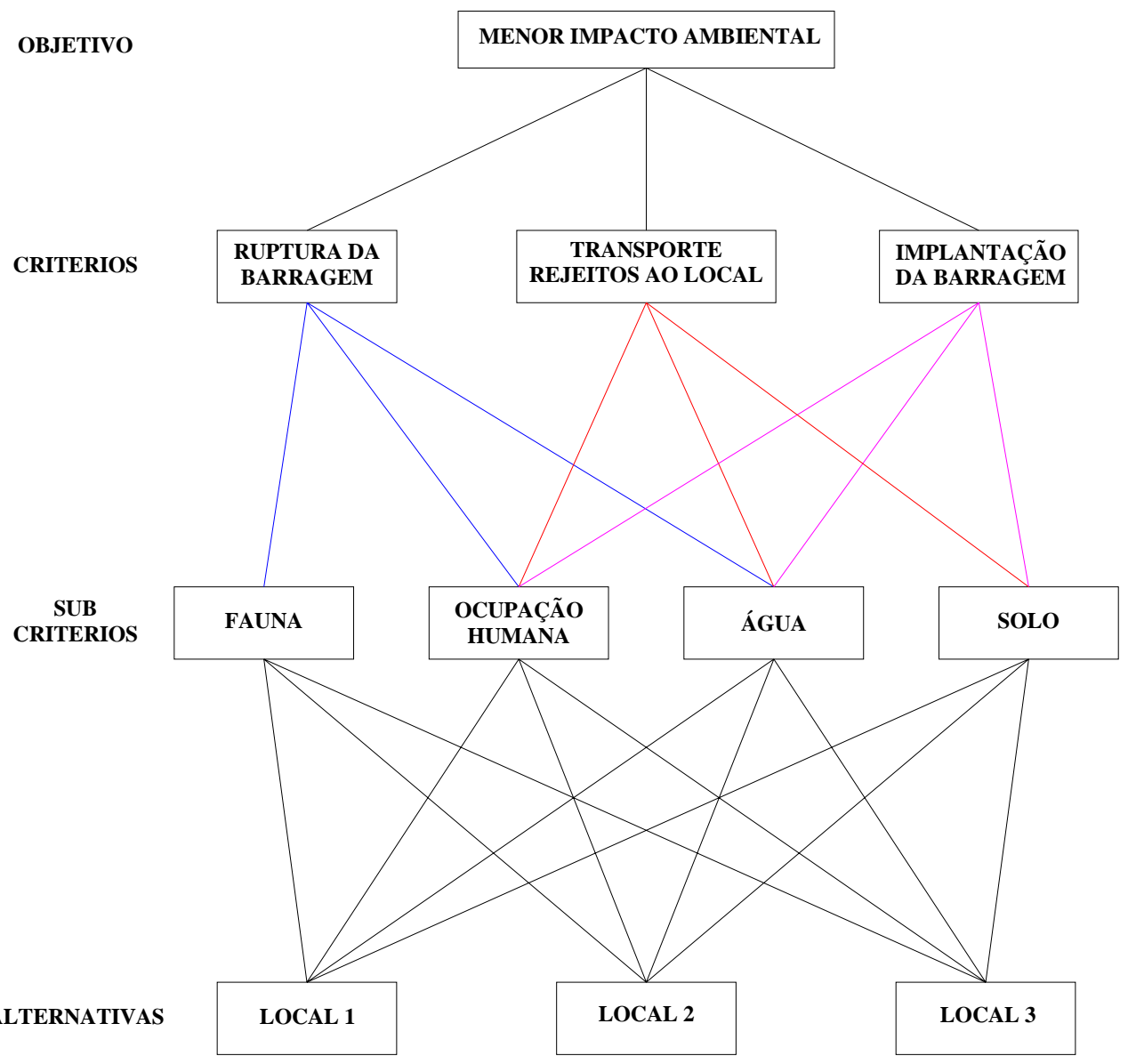

Figura 37. Hierarquia de ajuda na decisão de seleção de locais no estudo de caso.

A hierarquia do estudo de caso é uma hierarquia incompleta, pois nem todos os sub-critérios ser relacionam com todos os critérios, por exemplo, não há ligação entre o sub-critério Solo e o critério Ruptura da Barragem, ou do sub-critério Fauna com o critério Transporte de Rejeitos ao Local. Porém, uma hierarquia incompleta pode ser tratada como completa, usando zero onde não existem relações (Saaty 1980), como pode ser observado na Tabela 29.

\subsection{Julgamentos paritários, prioridades relativas e consistência.}

Nesta etapa são feitos os julgamentos entre critérios, sub-critérios e atributos, atribuindo os valores de julgamentos relativos propostos por Saaty (1980) na Tabela 14. As matrizes pareadas são construídas comparando-se a preferência de um elemento em relação ao outro. 
A Tabela 25 representa a matriz pareada do nível 2, composto pelos seguintes critérios: Ruptura da Barragem (RB), Transporte de Rejeitos ao Local (TR), Implantação da Barragem (IB). representa a matriz pareada do nível 2, composto pelos seguintes critérios: Ruptura da barragem (RB), Transporte de rejeitos ao local (TR), Implantação da barragem (IB). Na Tabela 26 são apresentadas as matrizes pareadas do nível 3, composto pelos sub-critérios: Fauna $(\mathrm{F})$, Ocupação humana $(\mathrm{OH})$, água $(\mathrm{A})$ e solo $(\mathrm{S})$. Nas tabelas estão também apresentados os autovetores e o produto da matriz pareada pelo autovetor.

Tabela 25. Matriz pareada do nível 2.

\begin{tabular}{|c|c|c|c|c|c|}
\hline & RB & TR & IB & Autovetor (C) & A C \\
\hline RB & $\mathbf{1}$ & $1 / 7$ & $1 / 3$ & 0,09 & 0,25 \\
\hline TR & 7 & $\mathbf{1}$ & 5 & 0,72 & 2,27 \\
\hline IB & 3 & $1 / 5$ & $\mathbf{1}$ & 0,19 & 0,59 \\
\hline Soma & & \multicolumn{5}{c|}{$\lambda_{\text {máx }}=3,07 ;$ IC $=0,03 ; \mathrm{RC}=0,06$}
\end{tabular}

Tabela 26. Matrizes pareadas do nível 3.

\begin{tabular}{|c|c|c|c|c|c|}
\hline Nível 2 & $(1)$ & $(2)$ & (3) & Autovetor & A C \\
\hline \multicolumn{6}{|l|}{ Ruptura da Barragem } \\
\hline (1) Fauna (F) & 1 & 1 & $1 / 2$ & 0,23 & 0,71 \\
\hline (2) Ocupação humana (OH) & 1 & 1 & $1 / 4$ & 0,19 & 0,57 \\
\hline \multirow[t]{2}{*}{ (3) Água (A) } & 2 & 4 & 1 & 0,58 & 1,79 \\
\hline & & & & \multicolumn{2}{|c|}{$\lambda_{\text {máx }}=3,05 \mathrm{IC}=0,03 \mathrm{RC}=0,05$} \\
\hline \multicolumn{6}{|l|}{ Transporte de rejeitos ao local } \\
\hline (1) Ocupação humana (OH) & 1 & $1 / 3$ & 3 & 0,26 & 0,79 \\
\hline (2) Água (A) & 3 & 1 & 5 & 0,63 & 1,95 \\
\hline \multirow[t]{2}{*}{ (3) solo $(\mathrm{S})$} & $1 / 3$ & $1 / 5$ & 1 & 0,11 & 0,32 \\
\hline & & & & \multicolumn{2}{|c|}{$\lambda_{\text {máx }}=3,04 \mathrm{IC}=0,02 \mathrm{RC}=0,03$} \\
\hline \multicolumn{6}{|l|}{ Implantação da Barragem } \\
\hline (1) Ocupação humana (OH) & 1 & $1 / 5$ & $1 / 7$ & 0,08 & 0,22 \\
\hline (2) Água (A) & 5 & 1 & $1 / 3$ & 0,28 & 0,87 \\
\hline (3) solo (S) & 7 & 3 & 1 & 0,64 & 2,01 \\
\hline
\end{tabular}

A Tabela 27 mostra as matrizes pareadas do nível 4, que corresponde às alternativas de local. 
Tabela 27. Matrizes pareadas do nível 4.

\begin{tabular}{|c|c|c|c|c|c|}
\hline Nível 3 & (1) & $(2)$ & (3) & Autovetor & A C \\
\hline \multicolumn{6}{|l|}{ Fauna } \\
\hline (1) Local 1 (L1) & 1 & 1 & 1 & 0,33 & 1,00 \\
\hline (2) Local 2 (L2) & 1 & 1 & 1 & 0,33 & 1,00 \\
\hline (3) Local 3 (L3) & 1 & 1 & 1 & 0,33 & 1,00 \\
\hline & & & & \multicolumn{2}{|c|}{$\lambda_{\text {máx }}=3,00 \mathrm{IC}=0,00 \mathrm{RC}=0,00$} \\
\hline \multicolumn{6}{|l|}{ Ocupação humana } \\
\hline (2) Local 2 (L2) & $1 / 4$ & 1 & 3 & 0,23 & 0,71 \\
\hline (3) Local 3 (L3) & $1 / 5$ & $1 / 3$ & 1 & 0,10 & 0,31 \\
\hline & & & & \multicolumn{2}{|c|}{$\lambda_{\text {máx }}=3,09 \mathrm{IC}=0,04 \mathrm{RC}=0,07$} \\
\hline \multicolumn{6}{|l|}{ Água } \\
\hline (2) Local 2 (L2) & 3 & 1 & 4 & 0,61 & 1,90 \\
\hline \multirow[t]{2}{*}{ (3) Local 3 (L3) } & $1 / 3$ & $1 / 4$ & 1 & 0,12 & 0,36 \\
\hline & & & & \multicolumn{2}{|c|}{$\lambda_{\text {máx }}=3,07 \mathrm{IC}=0,04 \mathrm{RC}=0,06$} \\
\hline \multicolumn{6}{|l|}{ Solo } \\
\hline (2) Local 2 (L2) & $1 / 2$ & 1 & $1 / 4$ & 0,13 & 0,40 \\
\hline (3) Local 3 (L3) & 5 & 4 & 1 & 0,68 & 2,16 \\
\hline
\end{tabular}

\subsection{Agregação de prioridades às alternativas.}

Os autovetores gerados para cada uma das matrizes são agrupados até obter os pesos finais para cada uma das alternativas, onde o maior peso corresponde à alternativa que gera o menor impacto ambiental. O autovetor da primeira matriz (nível critérios) encontra-se na Tabela 28.

Tabela 28. Autovetor da matriz do nível 2.

\begin{tabular}{c|c} 
RB & 0.08 \\
TR & 0.72 \\
IB & 0.19
\end{tabular}

Os autovetores da segunda matriz (nível sub-critérios) estão apresentados na Tabela 29. 
Tabela 29. Autovetores da matriz do nível 3.

\begin{tabular}{c|ccc|} 
& RB & TR & IB \\
\hline $\mathrm{F}$ & 0.23 & 0.00 & 0.00 \\
$\mathrm{OH}$ & 0.19 & 0.26 & 0.07 \\
$\mathrm{~A}$ & 0.58 & 0.63 & 0.28 \\
$\mathrm{~S}$ & 0.00 & 0.11 & 0.64
\end{tabular}

Os autovetores da terceira matriz (alternativas) estão apresentados na Tabela 30.

Tabela 30. Autovetores da matriz do nível 4.

\begin{tabular}{c|cccc} 
& F & OH & A & S \\
\hline L1 & 0.33 & 0.67 & 0.27 & 0.19 \\
L2 & 0.33 & 0.23 & 0.61 & 0.13 \\
L3 & 0.33 & 0.10 & 0.12 & 0.68
\end{tabular}

$\mathrm{O}$ vetor final de menor impacto ambiental obtido pelo produto matricial dos componentes das alternativas - sub-critérios - critérios é dado pela Tabela 31 .

Tabela 31. Vetor final de menor impacto ambiental.

\begin{tabular}{c|c|} 
LOCAL 1 & 0.34 \\
LOCAL 2 & 0.42 \\
LOCAL 3 & 0.23
\end{tabular}

Segundo esta escala de pesos, ao Local 2 corresponderia o menor impacto na construção da barragem de rejeitos, a seguir o Local 1 e por último o Local 3, que seria o de maior impacto ambiental. 


\subsection{Aplicação da variante multiplicativa do método de análise hierárquica.}

Neste item serão comparados os dados obtidos no vetor de pesos finais com a versão multiplicativa do AHP (ver item 5.7), para confirmar a classificação das alternativas. $\mathrm{Na}$ Erro! A origem da referência não foi encontrada. estão expostos os pesos da matriz de comparações encontrados no estudo de caso.

Tabela 32. Critérios e alternativas na variante multiplicativa do método AHP.

\begin{tabular}{|c|c|c|c|}
\hline \multirow{3}{*}{ 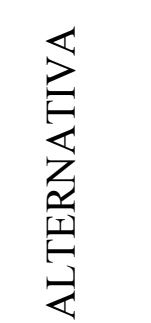 } & \multicolumn{3}{|c|}{ CRITÉRIO } \\
\hline & $\mathrm{RB}$ & TR & IB \\
\hline & $(0.08$ & 0.72 & $0.19)$ \\
\hline Local 1 & 0.36 & 0.37 & 0.25 \\
\hline Local 2 & 0.47 & 0.46 & 0.27 \\
\hline Local 3 & 0.17 & 0.17 & 0.48 \\
\hline
\end{tabular}

Aplicando a equação (17) aos dados Tabela 32 da obtém-se, para comparar as alternativas Local 1 e Local 2, os resultados da equação (18):

$$
\begin{aligned}
& \mathrm{R}\left(\mathrm{L}_{1} / \mathrm{L}_{2}\right)=\left(\frac{\mathbf{0 . 3 6}}{\mathbf{0 . 4 7}}\right)^{0.08} \times\left(\frac{0.37}{\mathbf{0 . 4 6}}\right)^{0.72} \times\left(\frac{0.25}{0.27}\right)^{0.19} \\
& \mathrm{R}\left(\mathrm{L}_{1} / \mathrm{L}_{2}\right)=\mathbf{0 . 8 2}
\end{aligned}
$$

Isto significa que o Local 1 é de menor peso que o Local 2 (Local $1<$ Local 2).

A equação (19) resultados da avaliação do par de alternativas Local 2 e Local 3.

$$
\begin{aligned}
& \mathrm{R}\left(\mathrm{L}_{2} / \mathrm{L}_{3}\right)=\left(\frac{0.47}{\mathbf{0 . 1 7}}\right)^{0.08} \times\left(\frac{0.46}{\mathbf{0 . 1 7}}\right)^{0.72} \times\left(\frac{0.27}{\mathbf{0 . 4 8}}\right)^{0.19} \\
& \mathrm{R}\left(\mathrm{L}_{2} / \mathrm{L}_{3}\right)=1.97
\end{aligned}
$$


Isto significa que o peso do Local 2 é maior do que o peso do Local 3 (Local $2>$ Local 3).

Finalmente a avaliação do par de alternativas Local 1 e Local 3 é mostrada na equação (20).

$\mathrm{R}\left(\mathrm{L}_{1} / \mathrm{L}_{3}\right)=\left(\frac{\mathbf{0 . 3 6}}{\mathbf{0 . 1 7}}\right)^{0.08} \times\left(\frac{0.37}{\mathbf{0 . 1 7}}\right)^{0.72} \times\left(\frac{0.25}{\mathbf{0 . 4 8}}\right)^{0.19}$
$\mathrm{R}\left(\mathrm{L}_{1} / \mathrm{L}_{3}\right)=1.61$

Isto significa que o Local 1 é de maior peso que o Local 3 (Local $1>$ Local 3).

A variante multiplicativa confirmou os resultados obtidos na análise hierárquica, acentuando as diferenças entre as alternativas.

\subsection{Análise de sensibilidade}

A sensibilidade da estrutura é analisada modificando-se os pesos de alguns elementos da estrutura hierárquica e agregando-se critérios ou sub-critérios.

Avaliou-se a alteração dos julgamentos paritários relativos ao sub-critério Água em cada um dos critérios, considerando-o mais vulnerável aos impactos, para simular uma situação de pressão de organismos ambientais fiscalizadores dos recursos hídricos, ou organizações nãogovernamentais ambientalistas, ou mesmo a comunidade local. A hierarquia foi recalculada colocando peso menor para a água nas comparações paritárias, ou seja, maior impacto.

Para o critério Ruptura da Barragem, nenhum alteração nos pesos dos julgamentos paritários resultou numa mudança de pesos finais das alternativas, mesmo quando os julgamentos paritários entre Água e Fauna e Água e Ocupação Humana passaram de, respectivamente, importância pequena $(2: 1)$ e importância forte $(4: 1)$ da primeira sobre a segunda (A:F e A:OH), para importância absoluta da segunda em relação à primeira (1:9).

Para o critério Transporte de Rejeitos ao Local, alterações nos julgamentos causaram uma preferência pelo Local 1, que passou a ser o de menor impacto ambiental. A Figura 38 (cálculos no Anexo 3) mostra o caso em que os pesos finais dos Locais 1 e 2 se igualam, pela simples modificação do julgamento paritário entre Água e Ocupação Humana, que passou de importância pequena (1:3) da segunda sobre a primeira (A:OH) para igual importância (1:1). Esse se mostrou o julgamento que mais influi neste critério, e em toda a hierarquia. As 
alterações no julgamento paritário entre Água e Solo, embora também influam nos pesos finais das alternativas, tem influência muito menor.

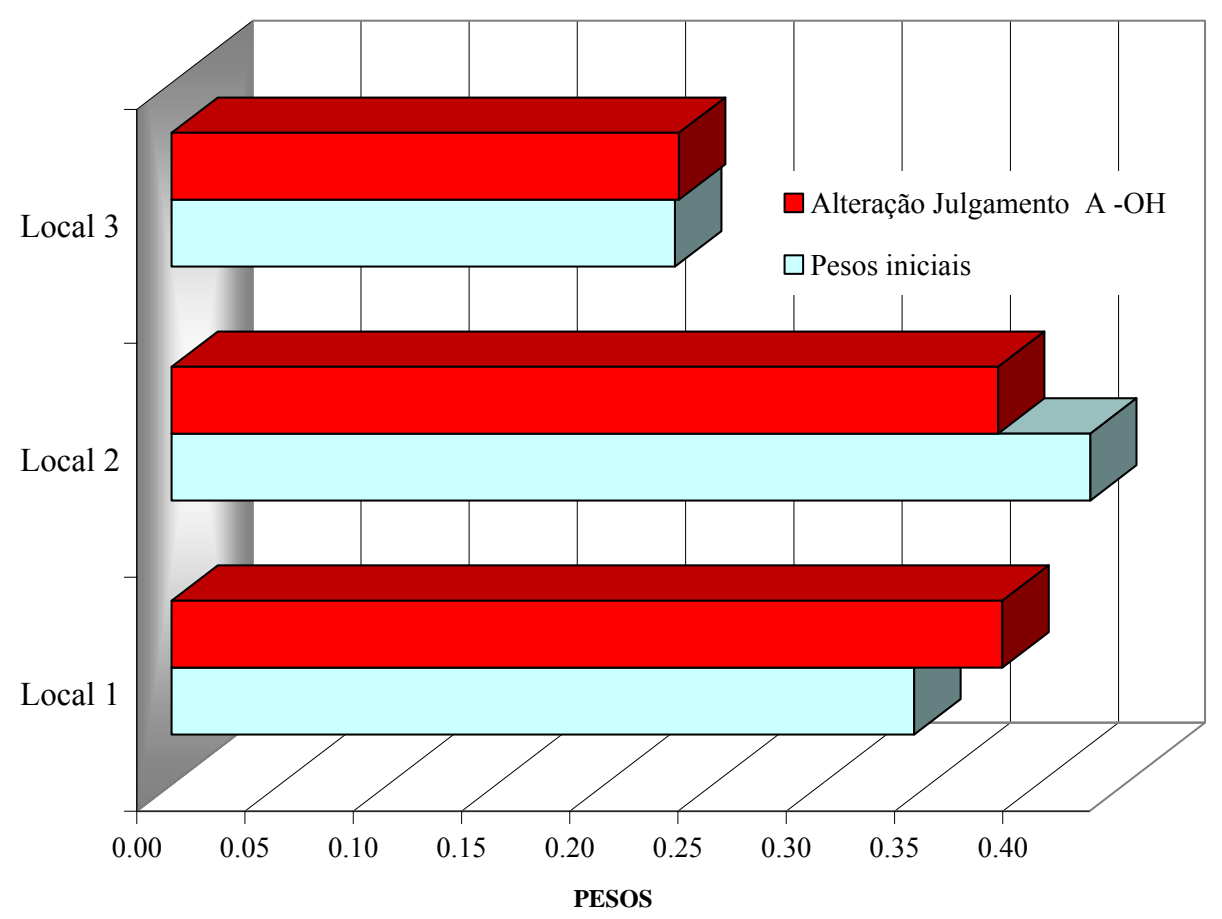

Figura 38. Alteracion Julgamento Água - Ocupação Humana.

Para o critério Implantação da Barragem, nenhum alteração nos pesos dos julgamentos paritários resultou numa mudança de pesos finais das alternativas, mesmo quando os julgamentos paritários entre Água e Fauna e Água e Ocupação Humana passaram de, respectivamente, importância forte da primeira sobre a segunda $(5: 1)$ para importância forte da segunda sobre a primeira (1:5), e de importância pequena (1:3) para importância absoluta da segunda em relação à primeira (1:9).

A análise de sensibilidade neste exemplo revela que, por mais vulnerável que se considere o sub-critério Água, o Local 2 é o de menor impacto ambiental, e o Local 1 só passa a ser preferido quando se considera o Transporte de Rejeitos ao Local. Este critério, contudo, é o de menor importância entre os três critérios na hierarquia.

\subsection{Considerações de custos dos locais}

O custo total de implantação de uma barragem de rejeitos depende de diversos fatores, tais como: o custo do terreno, os custos de escavação, os custos de terraplenagem, os custos de 
transporte de polpa ao local, as indenizações, os custos de acesso aos locais, os custos de tratamento dos efluentes, os custos de transporte de efluentes, os custos de restauração, entre outros (Johnston 1973).

Também os custos operacionais, os custos de manutenção e de fechamento deveriam ser avaliados, mas são muito difíceis de prever, já que dependem muito do tempo das operações da jazida. As empresas mineradoras em geral não projetam custos para o fechamento da barragem, que no entanto podem ser muito elevados. Neste sentido uma recomendação importante é distribuir os custos operacionais durante a vida útil da barragem, aplicando-os na manutenção das estruturas, para haver menores gastos no fechamento (McPhail 2006).

No estudo de caso o custo inicial total é trabalhado sob três aspectos:

- Custos do terreno $\left(\mathrm{C}_{\mathrm{Te}}=\mathrm{C}_{\mathrm{te}}+\mathrm{C}_{\mathrm{uh}}+\mathrm{C}_{\mathrm{up}}\right)$

- Custos de escavação $\left(\mathrm{C}_{\mathrm{es}}\right)$

- Custos do aterro $\left(\mathrm{C}_{\mathrm{at}}\right)$

Onde $\mathrm{C}_{\text {te }}, \mathrm{C}_{\mathrm{uh}}$, e $\mathrm{C}_{\mathrm{up}}$ são os custos do terreno, os custos das unidades habitacionais e os custos das unidades produtivas, respectivamente.

Todos os locais ficam numa cota inferior à usina de beneficiamento, e o transporte de polpa é feito por gravidade, não precisando de bombeamento. Então, os custos de transporte de polpa limitam-se aos custos da tubulação e aos custos de instalação (mão de obra, equipamento e materiais), podendo ser incluídos nos custos de operação da mina sem ser muito significativos no custo total inicial da barragem. Como apresentado na Tabela 18, os efluentes das barragens apresentam boas características e não precisam de tratamento químico.

O custo total (CT) está representado pela equação (21)

$$
\mathbf{C T}=\mathrm{C}_{\mathrm{te}}+\mathrm{C}_{\mathrm{uh}}+\mathrm{C}_{\mathrm{up}}+\mathrm{C}_{\mathrm{es}}+\mathrm{C}_{\mathrm{at}}
$$

Nos item 7.4.1, 7.4.2 e 7.4.3 foram calculados os volumes de escavação e de terraplenagem para cada local; aqui se adicionam as unidades habitacionais e as unidades produtiva de cada local, resumidos na Tabela 33. É importante observar que a área do terreno a ser comprado é muito maior do que a área de influência da barragem, pois geralmente os proprietários não 
vendem parte de seu terreno para continuar ocupando a outra parte não soterrada pelo reservatório; eles, infelizmente para a mineradora, vendem toda sua propriedade.

Tabela 33. Áreas, volumes, movimentos de terra e escavações nos diferentes locais.

\begin{tabular}{|l|c|c|c|c|c|}
\hline & $\begin{array}{c}\text { Área do local a ser } \\
\text { comprada } \\
\left.\left(\mathrm{m}^{2} \times 10^{3}\right)\right)\end{array}$ & $\begin{array}{c}\text { Escavação } \\
\left(\mathrm{m}^{3} \times 10^{3}\right)\end{array}$ & $\begin{array}{c}\text { Construção da } \\
\text { barragem } \\
\left(\mathrm{m}^{3} \times 10^{3}\right)\end{array}$ & $\begin{array}{c}\text { Unidades } \\
\text { habitacionais } \\
\left(\mathrm{m}^{2}\right)\end{array}$ & $\begin{array}{c}\text { Unidades produtivas } \\
\left(\mathrm{m}^{2}\right)\end{array}$ \\
\hline LOCAL 1 & 160 & 82 & 67,6 & $\begin{array}{c}2 \text { casas } \\
\left(190 \mathrm{~m}^{2}\right)\end{array}$ & 0 \\
\hline LOCAL 2 & 102 & 111 & 60,3 & 4 casas $\left(280 \mathrm{~m}^{2}\right)$ & 1 unidade $\left(150 \mathrm{~m}^{2}\right)$ \\
\hline LOCAL 3 & 150 & 299 & 0,0 & 0 & 0 \\
\hline
\end{tabular}

Deve-se lembrar que, no Local 3, a barragem vai ficar encaixada e não sobre a superfície original do terreno, como nos Locais 1 e 2. O item “Construção da barragem" refere-se só a trabalhos de aterramento.

\subsubsection{Custos dos terrenos}

Os custos dos terrenos $\left(\mathrm{C}_{\mathrm{Te}}\right)$ foram baseados no estudo feito por Quintero (2006), onde se calcula o valor do terreno considerando não só o preço por $\mathrm{m}^{2}$, como também incorporando os atributos físicos, geográficos e/ou do entorno do prédio. É definido um valor da terra como recurso potencial agrícola: terrenos com baixa declividade e água suficiente apresentam custos médios altos, e para terrenos em encostas íngremes os preços são menores. Este estudo foi feito analisando aproximadamente 14\% das propriedades rurais da Colômbia (395.550 propriedades com informações de clima, inclinação do terreno, custo potencial do terreno, uso do solo, disponibilidade de água e tipo de estradas vizinhas). Na Tabela 34 constam os resultados desse estudo, supondo-se um mesmo valor potencial do solo.

Tabela 34. Características médias das propriedades rurais com igual valor potencial do solo (Quintero 2006, modificada para reais ( $R \$)$ ).

\begin{tabular}{|c|c|c|c|c|c|c|c|c|}
\hline Características & \multicolumn{7}{|c|}{ IGUAL VALOR POTENCIAL DO SOLO } \\
\hline $\mathrm{R} \$ / \mathrm{m}^{2}$ & 0,05 & $\begin{array}{c}\mathrm{R} \$ / \\
\mathrm{m}^{2}\end{array}$ & 0,05 & $\mathrm{R} \$ / \mathrm{m}^{2}$ & 0,05 & $\begin{array}{c}\mathrm{R} \$ / \\
\mathrm{m}^{2}\end{array}$ & 0,05 & $\begin{array}{c}\mathrm{R} \$ / \\
\mathrm{m}^{2}\end{array}$ \\
\hline Inclinações & \multicolumn{2}{|c|}{$\begin{array}{c}\text { Levemente } \\
\text { íngreme }\end{array}$} & Inclinações & $\begin{array}{c}\text { Levemente } \\
\text { íngreme }\end{array}$ & $\begin{array}{c}\text { Inclinaçõe } \\
\mathrm{s}\end{array}$ & \multicolumn{3}{|c|}{ Levemente íngreme } \\
\hline Disponibilidade de água & \multicolumn{8}{|c|}{ Escassa } \\
\hline
\end{tabular}

Nota: 1 US\$ $=2,17 \mathrm{R} \$(\operatorname{set} / 2006)$ 
Quintero (2006) não considera a infra-estrutura existente no local (unidades habitacionais, barragens, currais, unidades produtivas, entre outras), a qual tem que ser avaliada à parte e adicionada aos custos do terreno.

Os custos de terreno para os Locais 1 e 2 flutuam entre $0,12 \mathrm{R} \$ / \mathrm{m}^{2}$ e $0,25 \mathrm{R} \$ / \mathrm{m}^{2}$, e para o Local 3, entre $0,25 \mathrm{R} \$ / \mathrm{m}^{2}$ e $0,32 \mathrm{R} \$ / \mathrm{m}^{2}$. Optou-se pelos valores máximos na análise, considerando o poder de negociação dos proprietários. Assim, os custos de terreno para os Locais 1,2 e 3 são, respectivamente, $\mathrm{R} \$ 40.000, \mathrm{R} \$ 22.500$ (para o Local 2 só se considerou a área de $90.000 \mathrm{~m}^{2}$ do terreno, os outros $12.600 \mathrm{~m}^{2}$ pertencentes à unidade produtiva são calculados mais adiante) e $\mathrm{R} \$ 48.000$.

\subsubsection{Custos das unidades habitacionais.}

Tomou-se como base o estudo de Bireaud (2001), segundo o qual unidades habitacionais rurais não se diferenciam muito das unidades básicas de interesse social, onde os próprios proprietários dos terrenos são encarregados de construir sua casa, com subsídios do governo nacional e empréstimo do banco rural para terminar a obra. A mão de obra é realizada pela própria família em parceria com vizinhos, às vezes com assistência técnica do município ou contratada pelo proprietário. Os custos correspondem a $163 \mathrm{R} \$ / \mathrm{m}^{2}$ (valores em Reais em setembro de 2006), inferiores em 30 a 40\% às unidades habitacionais em áreas urbanas. No Local 1 há $190 \mathrm{~m}^{2}$ construídos, equivalentes a duas casas, cujo custo é de $\mathrm{R} \$ 30.970$; no Local 2 há $280 \mathrm{~m}^{2}$ construídos, correspondentes a quatro casas, cujo custo é de $\mathrm{R} \$ 45.640$.

\subsubsection{Custo de unidades produtivas.}

A única unidade produtiva dos três locais encontra-se no Local 2 , com $12.600 \mathrm{~m}^{2}$ do terreno destinados à produção de leite e laticínios. A análise desses custos foi feita à luz dos resultados obtidos por Holmann et al. (2003), a partir dos dados provenientes de 545 fazendas produtoras de leite em diferentes regiões da Colômbia. Um dos resultados da pesquisa foi a Tabela 35, onde se apresentam os custos comerciais da terra e as inversões de capital (terra, infra-estrutura e equipamentos). 
Tabela 35. Inversão de capital em terras, infraestrutura e equipamentos. (Holmann 2003 - modificados os valores para reais $(\mathbf{R} \$))$.

\begin{tabular}{|c|c|}
\hline PARÂMETRO & REGIÃO DO ESTUDO \\
\hline & Antioquia \\
\hline Custo comercial da terra $\left(\mathrm{R} \$ / \mathrm{m}^{2}\right)$ & 0,79 \\
\hline $\begin{array}{c}\text { Inversão total de capital (infra-estrutura, } \\
\text { equipamento, gado) }\left(\mathrm{R} \$ / \mathrm{m}^{2}\right)\end{array}$ & 1,18 \\
\hline
\end{tabular}

Nota: $1 \mathrm{US} \$=2,17 \mathrm{R} \$(\operatorname{set} / 2006)$

O valor adotado é de $1,18 \mathrm{R} \$ / \mathrm{m}^{2}$, que representam as inversões totais de capital e que são os custos pelos quais os proprietários realmente querem ser indenizados. Para o Local 2, com $12.600 \mathrm{~m}^{2}$ de área disponível para produção de leite, o custo da unidade produtiva é de $\mathrm{R} \$ 14.868$.

Na Tabela 36 estão apresentados os custos totais dos três locais.

Tabela 36. Custo total dos terrenos (valores em reais (R\$), 2006).

\begin{tabular}{|c|c|c|c|c|}
\hline & Custo do terreno & $\begin{array}{c}\text { Custo das } \\
\text { unidades } \\
\text { habitacionais }\end{array}$ & $\begin{array}{c}\text { Custo das } \\
\text { unidades } \\
\text { produtivas }\end{array}$ & $\begin{array}{c}\text { Custo total do } \\
\text { terreno }\left(\mathbf{C}_{\mathbf{T e}}\right)\end{array}$ \\
\hline Local 1 & 40.000 & 30.970 & & $\mathbf{7 0 . 9 7 0}$ \\
\hline Local 2 & 22.500 & 45.640 & 14.868 & $\mathbf{8 3 . 0 0 8}$ \\
\hline Local 3 & 48.000 & & & $\mathbf{4 8 . 0 0 0}$ \\
\hline
\end{tabular}

\subsubsection{Custos das escavações.}

Os custos das escavações se dividem em dois tipos, dependendo dos materiais a escavar: as escavações em material comum e conglomerados e as escavações em rocha.

As escavações em material comum e conglomerados consistem num conjunto de atividades de escavar, remover, transportar e colocar nos locais indicados para sua posterior utilização e adequação nas obras de aterro; compreendem ademais os trabalhos de decapeamento (remoção da primeira capa vegetal), mão de obra e os equipamentos necessários para sua 
execução. Englobam escavações em solos consolidados e de alta coesão, de textura granular a fina, como também a remoção de pedras menores do que $0,75 \mathrm{~m}^{3}$.

As escavações em rocha compreendem toda a escavação de rocha de origem ígnea, metamórfica ou sedimentar de volume maior do que $0,75 \mathrm{~m}^{3}$ e em geral todo material que somente pode ser escavado mediante o uso de explosivos. Também incluem o conjunto de atividades de remoção, transporte e colocação nos sítios indicados para sua posterior utilização e adequação nas obras de aterro. Deve-se contemplar a mão de obra e os equipamentos necessários para a execução da obra.

Pelas condições geológicas observadas nos locais, estima-se que nos Locais 2 e $390 \%$ da escavação é em material de conglomerado e 10\% em rocha, e no Local 1, 70\% em material de conglomerado e $30 \%$ em rocha.

Os custos por $\mathrm{m}^{3}$ são tomados de orçamentos oficiais do ano 2006 da Secretaria de Planejamento da Colômbia (Oficina de Projetos ), convertidos em reais (R\$) e mostrados na Tabela 37.

Tabela 37. Custos de escavação (convertidos em reais (R\$)).

\begin{tabular}{|c|c|c|c|c|}
\hline Descrição & $\begin{array}{l}\text { Custo } \\
\mathrm{R} \$ / \mathrm{m}^{3}\end{array}$ & Local 1 & Local 2 & Local 3 \\
\hline $\begin{array}{l}\text { Escavação em material } \\
\text { comum e conglomerado }\end{array}$ & 14,68 & 842.632 & $1 ’ 466.532$ & 3'950.388 \\
\hline Escavações em rocha & 21,04 & 517.584 & 233.544 & 629.096 \\
\hline \multicolumn{2}{|c|}{ Total custo escavações $\left(\mathrm{C}_{\mathrm{es}}\right)$} & 1.360 .216 & 1.700 .076 & 4.579.484 \\
\hline
\end{tabular}

\subsubsection{Custos do aterro}

Estes custos são relativos ao transporte, colocação em camadas e compactação à densidade específica do material do aterro. O material deve atender às especificações estabelecidas e de preferência se utiliza o material das escavações (95\%). A construção do aterro inclui a mão de obra e equipamento. Os custos foram tomados da revista Construção (2006) e apresentados na Tabela 38. 
Tabela 38. Custos de terraplenagem (valores em reais ( $R$ \$)).

\begin{tabular}{|c|c|c|c|c|}
\hline Descrição & Custo $\mathrm{R} \$ / \mathrm{m}^{3}$ & Local 1 & Local 2 & Local 3 \\
\hline $\begin{array}{c}\text { Custos do aterro } \\
\left(\mathbf{C}_{\mathbf{a t}}\right)\end{array}$ & 23,79 & $\mathbf{1 . 6 0 8 . 2 0 4}$ & $\mathbf{1 . 4 3 4 . 5 3 7}$ & $\mathbf{0}$ \\
\hline
\end{tabular}

\subsubsection{Custos totais}

Os custos totais para cada local segundo a equação (21) estão resumidos na Tabela 39.

Tabela 39. Custos totais

\begin{tabular}{|c|c|c|c|c|}
\hline & $\mathbf{C}_{\text {Te }}$ & $\mathbf{C}_{\text {es }}$ & $\mathbf{C}_{\text {at }}$ & CT \\
\hline Local 1 & $\mathbf{7 0 . 9 7 0}$ & $\mathbf{1 . 3 6 0 . 2 1 6}$ & $\mathbf{1 . 6 0 8 . 2 0 4}$ & 3.039 .390 \\
\hline Local 2 & $\mathbf{8 3 . 0 0 8}$ & $\mathbf{1 . 7 0 0 . 0 7 6}$ & $\mathbf{1 . 4 3 4 . 5 3 7}$ & 3.217 .621 \\
\hline Local 3 & 48.000 & 4.579 .484 & 0 & $\mathbf{4 . 6 2 7 . 4 8 4}$ \\
\hline
\end{tabular}

\subsection{Análise conjunta de custos totais e pesos resultantes da análise hierárquica.}

Segundo Soares (2002), após sintetizar as prioridades, o método de análise hierárquica apresenta um vetor único de valores normalizados que representa a classificação das alternativas. $\mathrm{O}$ autor recomenda que o mesmo seja feito com os valores obtidos para os aspetos econômicos, de modo a viabilizar a interação entre os fatores de classificação das alternativas e os custos totais. Essa etapa é realizada considerando qual é a proporção de aspecto econômico total associado a um local, segundo a equação (22)

$$
\sigma_{i}=\frac{C_{i}}{\sum_{m=1}^{n} C_{m}}
$$

Onde $\sigma_{i}=$ coeficiente de aspecto econômico da alternativa $i$

$\mathrm{C}_{\mathrm{i}}=$ aspecto econômico de $i$

$\mathrm{n}=$ número de alternativas existentes no processo.

Para o estudo de caso, os coeficientes de aspecto econômico dos três locais estão apresentados na Tabela 40 
Tabela 40. Coeficientes de aspecto econômico.

\begin{tabular}{c|c} 
Local & $\sigma_{\mathrm{i}}$. \\
\hline LOCAL 1 & $\mathbf{0 , 2 7 9}$ \\
LOCAL 2 & $\mathbf{0 , 2 9 6}$ \\
LOCAL 3 & $\mathbf{0 , 4 2 5}$
\end{tabular}

Após a aplicação do modelo de decisão e obtenção do coeficiente de aspecto econômico das alternativas, atribui-se a cada local um par ordenado numa matriz de classificação, que associa o valor porcentual do custo total ao peso final, conforme esquematizado na Figura 39. Soares (2002) sugere que a escala seja definida de modo que seus pontos extremos coincidam sempre com o valor mínimo e o valor máximo observados nas alternativas, em ambos eixos.

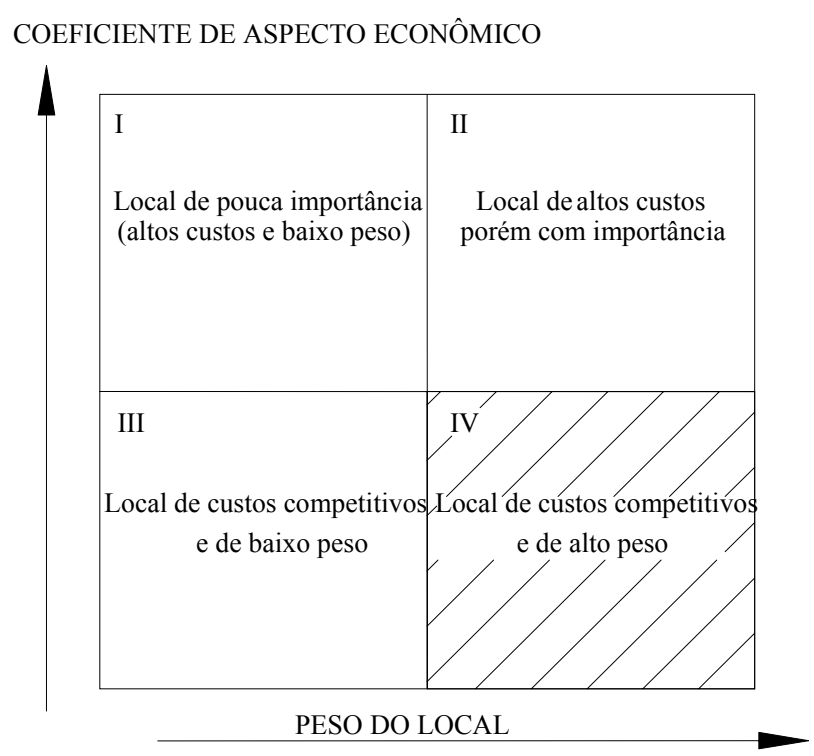

Figura 39. Representação das variáveis coeficiente de aspecto econômico e peso do local (Soares 2002, modificado).

Observando a Figura 39, o tomador de decisões busca identificar locais cujo par ordenado fique no quadrante IV. Se nenhuma alternativa se encontra nesse quadrante, se considerarão os quadrantes II e III. Se duas alternativas estiverem no mesmo quadrante, o critério de desempate será o de menor custo.

A Figura 40 mostra a análise conjunta de custos totais e pesos resultantes da análise hierárquica para o estudo de caso. Observa-se que os Locais 1 e 2 se encontram no quadrante IV, sendo que o Local 1 apresenta o menor custo total. Esta seria uma possível decisão para o 
problema proposto. Porém, a maior vantagem da matriz apresentada na Figura é a possibilidade de visualizar a situação de cada local, estando a decisão sujeita a negociações ou planejamento estratégico.

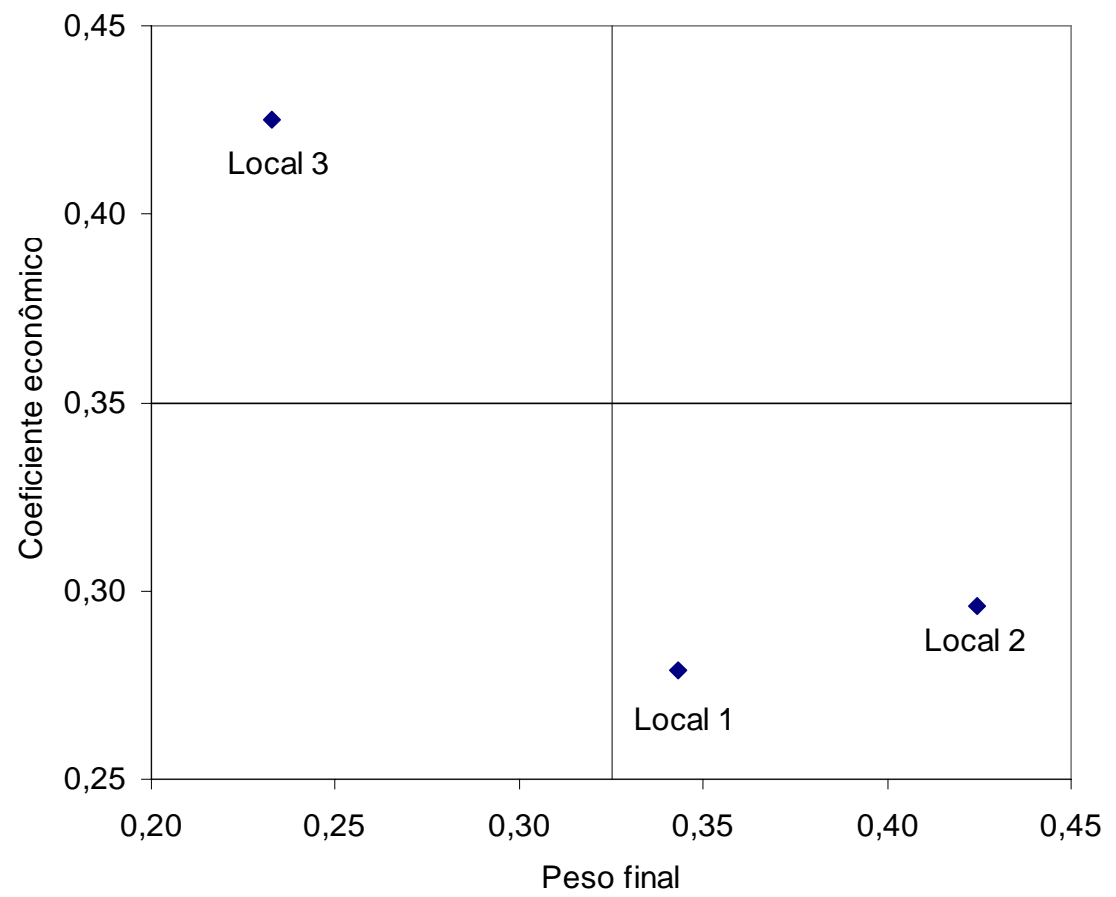

Figura 40. Análise conjunta de custos totais e pesos resultantes. 


\section{CONCLUSÕES}

Uma contribuição importante da pesquisa foi a concepção da lista de atributos apresenta na Tabela 17, que pode servir como um bom começo nas atividades de seleção de locais para barragens de rejeitos, orientando a coleta de dados necessária para posterior utilização em qualquer método racional de tomada de decisões. Procurou-se elaborar uma lista de atributos abrangente e consistente, que se pode modificar segundo as necessidades dos tomadores de decisão.

Na seleção de alternativas de localização de barragens de rejeito, a geoquímica e a geologia jogam um papel muito importante na eliminação de áreas impróprias. Os trabalhos de prospecção nas empresas mineradoras são registrados historicamente e podem ser sistematizados em "softwares". Recomenda-se fortemente a utilização dessas informações regionais antes da definição das alternativas de local e coleta de dados correspondentes.

O método de análise hierárquica (AHP) permite considerar muitos atributos e suas interações, é de fácil execução, minimiza a subjetividade, organiza o trabalho melhorando sua visualização e fornece uma ordenação por pesos globais.

Um das conclusões mais importantes desta pesquisa é que a experiência joga um papel importantíssimo na tomada de decisões. A utilização do método de análise hierárquica não se limita a definir o problema (no caso, escolher a melhor alternativa para localizar uma barragem de rejeitos) e aplicar a metodologia; é necessário envolver-se com o problema, obtendo informações a partir da bibliografia, visitas ao campo, diversas fontes, consultas a especialistas, e finalmente, realizar uma revisão crítica com base na experiência própria do tomador de decisão.

Grande parte da dificuldade na utilização do método de análise hierárquica não está na fase de avaliação, isto é, no preenchimento e cálculo das matrizes, mas sim na fase da definição e estruturação dos critérios e sub-critérios, ou seja, na elaboração da hierarquia. Comparem-se as tabelas de indicadores elaboradas por vários profissionais (Tabela 13, inclusive a Tabela 17), e a hierarquia resultante (Figura 37): a partir de conhecimento técnico pré-existente, é necessário elaborar o problema do ponto de vista dos objetivos, trabalhando-o de acordo com 
aspectos fundamentais, os quais podem ser compreendidos por todos os atores envolvidos, inclusive os leigos na área de engenharia de barragens.

A aplicação manual do AHP, por meio de planilhas EXCEL, em vez da utilização de "softwares" disponíveis, permitiu um maior controle e compreensão das etapas metodológicas.

No caso de alternativas de pesos finais semelhantes, o AHP, quando trabalhado com a sua variante multiplicativa, permite confirmar quais alternativas têm maior peso sob as outras, evitando o problema de reversão.

As análises de sensibilidade permitem ao tomador de decisões modificar os julgamentos paritários dos critérios e sub-critérios, encontrando novos elementos de decisão, como visto no item 8.6, onde com mínimas alterações nos julgamentos as decisões se modificam drasticamente. É importante ressaltar que as análises de sensibilidade não são feitas modificando os julgamentos paritários sem critério, "jogando números"; é preciso conhecer em profundidade o problema e desejar conhecer a influência de um determinado critério ou sub-critério.

A análise conjunta de custos totais e pesos resultantes da hierarquia permitiu observar globalmente o problema; assim, o tomador de decisão tem a possibilidade de escolher a melhor proposta dependendo de seus objetivos estratégicos e de planejamento.

Como sugestão para prosseguimento da pesquisa, propõe-se a realização de novos estudos focados no uso da análise conjunta para avaliar diferentes aspectos relacionados à vida útil de uma barragem de rejeitos, por exemplo, custo-risco ou custo-segurança estrutural da obra, em diferentes pacotes hierárquicos, e assim obter melhores decisões quando se tenha selecionado o local de obra.

Também seria interessante repetir a análise de sensibilidade para outros sub-critérios, inclusive com a agregação de critérios, sub-critérios e alternativas. 


\section{REFERENCIAS.}

ARANGO, J. C. Escogencia de blancos para exploración regional de acuerdo al análisis y procesamiento sistematizado de informacion e imágenes de sensores remotos en la región del Carmen de Atrato (Chocó). Medellín, Ant.: MINER S.A., 2003.

ARNEZ, F. I. V. Avaliação das principais causas de acidentes em barragens de contenção de rejeitos devido a fatores geológicos e geotécnicos. 1999. $83 \mathrm{f}+$ anexo. (Dissertação) Mestrado - Escola Politécnica, Universidade de São Paulo, São Paulo, 1999.

ASSIS, A; ESPÓSITO, T. Construção de barragens de rejeitos sob uma visão geotécnica. In: SIMPÓSIO SOBRE BARRAGENS DE REJEITOS E DISPOSIÇÃO DE RESIDUUOS REGEO'95, 3., Ouro Preto, MG. Anais... Ouro Preto, MG: ABMS/ABGE/CBGB, 1995. p. 259-273. v.1.

BIREAUD, J. M.; BRILL, I. U. Colombia el remanso de comfandi-fundacion carvajal: estudio BID vivienda: problematica y oportunidades para la provision integrada de terrenos equipados y credito para la vivienda progresiva.. Colombia: ACT Consultants, $2001.57 \mathrm{p}$.

BRAWNER, C. O.; CAMPBELL, D. B. The tailings structure and its characteristics: a soil engineer's viewpoint: tailings disposal today, In: INTERNATIONAL TAILING

SYMPOSIUM, 1., 1973, Tucson, Arizona. Proceedings... Tucson, Arizona: Miller Freeman Publications,1973. p. 59-101.

BURKE, H. H. Structural characteristics resulting from construction methods: tailing disposal today. In: INTERNATIONAL TAILING SYMPOSIUM, 1., Tucson, Arizona, 1973.

Proceedings...Tucson, Arizona: Miller Freeman Publications, 1973. p. 211-223.

CALDWELL, J. A.; ROBERTSON, A. M. Selection of tailings impoundment sites. Die Sivieleingenieur in Suid Africa, Sul da África, p. 537-553, oct. 1983. Disponível em: < http://www.robertsongeoconsultants.com/papers/tailings.pdf $>$. Acesso em: 15 ago. 2005.

CARVALHO, C. S. Gerenciamento de riscos geotécnicos em encostas urbanas: uma proposta baseada na analise de decisão. 1996. 192 f. Tese (Doutorado) - Escola Politécnica, Universidade de São Paulo, São Paulo, 1996.

CARVALHO, M. M. QFD: uma ferramenta de tomada de decisão em projeto. 1997. 162 f. + anexos. Tese (Doutorado) - Escola Politécnica, Universidade de São Paulo, São Paulo, 1997. 
CONSTRUÇÃO MERCADO. São Paulo: Pini, n.59, jun. 2006.

ENOKI, C. H. Gestão de processos de negócio: uma contribuição par avaliação de soluções de Business Process Management (BPM) sob a ótica da estratégia de operações. 2006. $202 \mathrm{f}$. + anexos. Dissertação (Mestrado) - Escola Politécnica, Universidade de São Paulo, São Paulo, 2006.

ESPÓSITO, T. D. J. Metodologia probabilística e observacional aplicada a barragens de rejeitos construídas por aterro hidráulico. 2000. $363 \mathrm{f}$. Tese (Doutorado) - Faculdade de Tecnologia, Universidade de Brasília, Brasília, DF, 2000.

FARIA, C. E. G. A mineração e o meio ambiente no Brasil. [S.1.]: CGEE, 2002. 41 p. Disponível em: <http://www.cgee.org.br/arquivos/estudo011_02.pdf $>$. Acesso em: 10 jan. 2005.

FIGUEREDO, A. D. S. Metodologia para o planejamento do transporte urbano: um enfoque para o processo empresarial do serviço por ônibus. 1999. $186 \mathrm{f}$. Tese (Doutorado) Escola de Engenharia de São Carlos, Universidade de São Paulo, São Carlos, 1999.

GALVES, M. L. Condicionantes geotécnicos do traçado de rodovias: uma proposta metodológica de escolha baseada na analise de decisões com objetivos múltiplos. 1995. $235 \mathrm{f}$. Tese (Doutorado) - Escola Politécnica, Universidade de São Paulo, São Paulo, 1995.

GARBER, M. F. Estruturas flutuantes para exploração de campos de petróleo no mar (FPSO): Apoio à decisão na escolha do sistema. 2002. 91 f. Dissertação (Mestrado) - Escola Politécnica, Universidade de São Paulo, São Paulo, 2002.

GONÇALVES, P. G. Contribuição ao estudo de conflitos na implantação do ferroanel na região metropolitana de São Paulo. 2005. 165 f. Dissertação (Mestrado) - Escola Politécnica, Universidade de São Paulo, São Paulo, 2005.

HOLMANN, F. et al. Evolución de los sistemas de produccion de leche en el tropico latinoamericano y su interrelacion con los mercados: un analisis del caso Colombiano. Colombia, 55 p. Disponível em:

$<$ http://grupochorlavi.org/php/doc/documentos/evolucionsistemas.pdf $>$. Accesso em: 12 set. 2006 .

IAÑEZ, M. M. Uma contribuição ao processo decisório de terceirização das atividades logísticas. 2002. 260 f. Dissertação (Mestrado) - Escola Politécnica, Universidade de São Paulo, São Paulo, 2002. 
INTERNATIONAL COUSIN ON METALS AND THE ENVIRONMENTAL. United Nations Environment Programme. Case studies on tailings management. Ottawa, Ontario, Canada: ICME; Paris: UNEP, nov. 1998, 66 p. Disponível em: <http://www.naturalresources.org/minerals/cd/docs/unep/tailingscasestudies.pdf $>$. Acesso em: 19 maio 2004.

JOHNSTON, C. Tailing disposal - its hidden costs: tailings disposal today, In: INTERNATIONAL TAILING SYMPOSIUM, 1.,1973, Tucson, Arizona. Proceedings... Tucson, Arizona: Miller Freeman Publications, 1973. p. 763-815.

\section{LA ASOCIACION DE MINERA DE CANADA Guía para la administración de} instalaciones de relaves. Ottawa, Ontário, Canadá, 1998. 58 p. Disponível em: < http://www.mining.ca/www/media_lib/MAC_Documents/Publications/FrenchSpanish/Guides p.pdf $>$. Acesso em: 20 maio 2005.

LIPORACI, S. R.; ZUQUETTE, L. V. Carta de zoneamento geotécnico geral utilizada para indicar áreas favoráveis à disposição de rejeitos. In: SIMPÓSIO SOBRE BARRAGENS DE REJEITOS E DISPOSIÇÃO DE RESÍDUOS - REGEO'95, 3., Ouro Preto, MG. Anais... Ouro Preto, MG: ABMS/ABGE/CBGB, 1995. p 135-147. v.1.

LISBOA, M. V. Contribuição para tomada de decisão na classificação e seleção de alternativas de traçado para rodovias em trechos urbanizados. 2002. 194 f. Dissertação (Mestrado) - Escola Politécnica, Universidade de São Paulo, São Paulo, 2002.

MARQUES, N. G. Seleção de áreas para aterros sanitários baseada em mapeamento geotécnico e analytic hierarchy process - AHP. 2002. $163 \mathrm{f}+$ anexos. Dissertação (Mestrado) - Escola de Engenharia de São Carlos, Universidade de São Paulo, São Carlos, 2002.

McPHAIL, G. Implications of diferent tailings disposal options on future rehabilitation. In: MINE TAILINGS 2006, 2006, Brisbane, Queensland.[Trabalhos apresentados]. Brisbane, Queensland: [s.n.], 2006. 16 p. Disponível em: <

http://www.infomine.com/publications/docs/McPhail2006.pdf>. Acesso em: 20 maio 2005.

MELLO, F. M. Segurança de barragens. In: SEMINÁRIO NACIONAL DE GRANDES BARRAGENS, 14., 1981, Recife, PE. Anais... Recife, PE: CBGB, 1981. p 343. v. 4.

MELLO, V. F. B. de. Diferenças sérias entre barragens de acumulação de água e de rejeitos. In: SIMPÓSIO SOBRE BARRAGENS DE REJEITOS E DISPOSIÇÃO DE RESÍDUOS INDUSTRIAIS E DE MINERAÇÃO, dez. 1987, Rio de Janeiro. Barragens de rejeitos e disposição de resíduos industriais e de mineração: anais. Rio de Janeiro :

Abms/abge/cbgb/dtg-Ce, 1987. p. 1-43, v.2. 
MOARES, W. N. Analise de investimentos am empresas de internet: estudo de casos múltiplos usando o AHP - Analytic Hierarchy Process. 2003. 123 f. Dissertação (Mestrado) Escola Politécnica, Universidade de São Paulo, São Paulo, 2003.

MORENO JIMENEZ, J. M.; ESCOBAR URMELETA, M. T. El pesar en el proceso analitico jerarquico 1. Estudios de Economía Aplicada, Madrid, España, v. 14, p. 95-115, 2000. Disponível em: < http://redalyc.uaemex.mx/redalyc/pdf/301/30114105.pdf $>$. Acesso em: 20 maio 2005.

MORITA, H. Revisão do método de análise hierárquica - MAH (AHP - Analytic Hierarchy Process). 1998. 129 f. + apêndice. Dissertação (Mestrado) - Escola Politécnica, Universidade de São Paulo, São Paulo, 1998.

NAKAHARA, H. et al. Selection of MSW landfill site by means of the analytic hierarchy process. In: INT. CONGRESS ON ENVIRONMENTAL GEOTECHNICS - ICEG, 4., 2002, Lisse. Proceedings... Lisse: Swets \& Zeitilinger, 2002, v. 1, p. 407-412.

NIEBLE, C. M. Deposição de rejeitos: curso de geotécnica aplicada à minas à céu aberto. Itabira, MG: Abib Engenharia S.A., 1986. 28p. il. Apostila.

NIEBLE, C. M; ROCHA, R. dos S. Método construtivo usa rejeitos para construir barragem de deposição. Construção Pesada, São Paulo, v. 6, n. 70, p 90-96, 1976.

NITTETSU MINING CO. LTD). Informes internos. Medellín: Miner S.A, 1991. Apostila.

NUNES DA SILVA, A. Geoprocessamento e sensoriamento remoto como apoio ao planejamento territorial do município de Ipiranga-SP. 2002. 200 f. Dissertação (Mestrado) - Instituto de Geociências, Universidade de São Paulo, São Paulo 2002.

ORTIZ, B. F. El Roble, un ejemplo colombiano de un yacimiento de sulfuros masivos volcanogénicos. 1988. $55 \mathrm{f}$. Trabajo de investigación presentado como requisito parcial para la promoción a Profesor Titular. Universidad Nacional de Colombia, Seccional Medellín, Colombia, 1988.

POMERANZ, L. Avaliação de projetos públicos: metodologia alternativa. São Paulo: IPE/USP, c1991. 141 p. (Relatório de pesquisas; RP-48).

QUINTERO, C. Y. Valorizacion de la tierra rural en Colombia. Civilizar, revista electronica de difusion cientifica. Bogotá, Colombia: Universidad Santiago Arboleda, v. 10,. jun. 2006. Disponible em: <http://www.usergioarboleda.edu.co/civilizar/>. Acesso em: 11 set. 2006. 
RIBEIRO, L. F. M. Simulação física do processo de formação dos aterros hidráulicos aplicado a barragens de rejeitos. 2000. 297 f. Tese (Doutorado) - Faculdade de Tecnologia, Universidade de Brasília, Brasília, DF, 2000.

RITCEY, G. M. Problems and solutions in the mining industry. Tailings Management: Elservier Science Publishers, 1989.

ROBERTSON, A. M. Site selection and design options for uranium mine waste and plant tailings. In: COUNCIL OF MINING AND METALLURGICAL INSTITUTIONS - CMMI CONGRESS, 12., 1982, Johannesburg, South Africa. Proceedings... Johannesburg, South Africa: Institution of Mining and Metallurgy, 1982. p. 861-886. Disponível em: $<$ http://www.robertsongeoconsultants.com/papers/mine_waste.pdf $>$. Acesso em: 15 ago. 2005 .

ROBERTSON, A. M.; MOSS, A. S. Site selection and optimization studies for mill sites and tailings impoundments. Asian Mining, Canada, p.301-311, 1981. Disponível em: < http://www.robertsongeoconsultants.com/papers/mill_site.pdf >. Acesso em: 15 ago. 2005.

ROBERTSON, A. M.; SHAW, S. C. Use of the multiple accounts analysis process for sustainability pptimization. In: SME ANNUAL MEETING, 2004, Denver, Colorado. Proceedings... Denver, Colorado: [s.n.], 2004. 8 p. Disponível em: < http://www.robertsongeoconsultants.com/papers/MAA_SME_2004.pdf >. Acesso em: 15 ago. 2005.

ROBERTSON, A. M.; SHEPHERD, T.; VAN ZYL, D. Uranium tailings impoundment site selection. In: SYMPOSIUM ON URANIUM MILL TAILINGS MANAGEMENT, 1980, Fort Collins, Colorado. [Trabalhos apresentados]. Fort Collins, Colorado: [s.n.], nov. 1980. Disponível em: $<$ http://www.robertsongeoconsultants.com/papers/tailings.pdf $>$. Acesso em: 15 ago. 2005.

ROBERTSON, A..M.; SHAW, S. C. A multiple account analysis for tailings site selection, In: SUDBURY '99 CONFERENCE MINING AND THE ENVIRONMENT, 2., 1999, Sudbury, Ont., Canada. Proceedings...,Sudbury, Ont., Canada: Centre in Mining and Mineral Exploration Research, Laurentian University, 1999. p. 883-891. v. 3. Disponível em: $<$ http://www.robertsongeoconsultants.com/papers/ssanalysis.pdf > . Acesso em: 15 ago. 2005.

ROSENBLOOM, E. S. A probabilistic interpretation of the final rankings in AHP. European journal of operational research, Amsterdam, v. 96, p. 371-378, 1996.

SAATY, T. Basic theory of the analytic hierarchy process: how to make a decision. Revista de la Real Academia de Ciencias Exactas Físicas y Naturales, España, v. 93, n. 4, p. 395423, 1999. 
SAATY, T. Fundamentals of decision making and priority theory with the analytic hierarchy process. Pittsburgh, Pa.: RWS Publications, 2000.

SAATY, T. The analytc hierarchy process. New York: McGraw-Hil, 1980. 287 p.

SANCHEZ, L. E. Manejo de residuos sólidos en mineria. In: CURSO INTERNACIONAL DE ASPECTOS GEOLÓGICOS DE PROTECCIÓN AMBIENTAL, 2., 2000, Campinas. Notas de clases Montevideo. Montevideo: UNESCO, 2002. p 249-250.

SCHOLL, A. et al. Solving multiattribute design problems with analytic hierarchy process and conjoint analysis: An empirical comparison. European Journal of Operational Research, Amsterdam, v. 164, p. 760-777, 2004.

SILVA, V. G. Avaliação da sustentabilidade de edifícios de escritórios brasileiros: diretrizes e base metodológica. 2003. 210 f. Tese (Doutorado) - Escola Politécnica, Universidade de São Paulo, São Paulo, 2003.

SILVEIRA, E.B.S.; READES, D.W. Barragens para contenção de rejeitos. In: SEMINÁRIO NACIONAL DE GRANDES BARRAGENS, 9, 1973, Rio de Janeiro. Anais... Rio de Janeiro: SNGB, 1973. 35 p. Tema 2.

SOARES, L. Barragens de contenção de rejeitos: metodologia de implantação, operação e manutenção. São Paulo: EPUSP-IM, 1998. 74 p. Apostilla de Aula.

SOARES, M. G. Classificação de operadores terceirizados, visando o estabelecimento de parcerias de negocio no contexto logístico empresarial. 2002. 165 f. Dissertação (Mestrado) - Escola Politécnica, Universidade de São Paulo, São Paulo 2002.

TRIANTAPHYLLOU, E. Two new cases of rank reversals when the AHP and some of its additive variants are used that do not occur with the multiplicative AHP. Journal of Multicriteria decision analysis. New Jersey, USA, v. 10, p. 11-25, 2001.

VICK, S. G. Planning, design and analysis of tailing dams. New York: John Wiley \& Sons, 1983. $369 \mathrm{p}$.

VICK, S. G. Siting and desing of tailings impoundments. Mining Engineering, New York, v. 33, n. 6, p. 653-657, 1981.

ZAHIR, A. S. Incorporating the uncertainty of decision judgments in the analytic hierarchy process. European journal of operational research, Amsterdam, v. 53, p. 206-216, 1991. 
ZUFFO, A. C. Seleção e aplicação de métodos multicriteriais ao planejamento ambiental de recursos hídricos. 1998. 301 f. Tese (Doutorado) - Escola de Engenharia de São Carlos, Universidade de São Paulo, São Carlos, 1998.

ZUQUETTE, L.V.; GANDOLFI, N. Cartografia geotécnica. São Paulo: Oficina de Textos, 2004. 190 p. 


\section{ANEXOS}

\section{Anexo 1. Valores Totais mensais de precipitação (Fonte: IDEAM, 2001).}

I D E A M - INSTITUTO DE HIDROLOGIA, METEOROLOGIA Y ESTUDIOS AMBIENTALES VALORES TOTALES MENSUALES DE PRECIPITACION (mms)

FECHA DE PROCESO : 2001/08/23

$\begin{array}{lllllll}\text { LATITUD } & 0554 \mathrm{~N} & \text { TIPO EST } & \text { PM } & & \text { DEPTO } & \text { CHOCO } \\ \text { LONGITUD } & 7612 \mathrm{~W} & \text { ENTIDAD } & 01 & \text { IDEAM } & \text { MUNICIPIO } & \text { EL CARMEN } \\ \text { ELEVACION } & 1850 \mathrm{~m} . \mathrm{s} . \mathrm{n} . \mathrm{m} & \text { REGIONAL } & 01 & \text { ANTIOQUIA } & \text { CORRIENTE } & \text { ATRATO }\end{array}$

SISTEMA DE INFORMACION NACIONAL AMBIENTAL

ESTACION : 1102001 CARMEN DE ATRATO FECHA-INSTALACION 1958-OCT FECHA-SUSPENSION

AHO EST ENT ENERO * FEBRE * MARZO * ABRIL * MAYO * JUNIO * JULIO * AGOST * SEPTI * OCTUB * NOVIE * DICIE * VR ANUAL *

\begin{tabular}{|c|c|c|c|c|c|c|c|c|c|c|c|c|c|c|c|}
\hline 1980 & 2 & 01 & 105.0 & 101.0 & 62.0 & 178.0 & 342.0 & 219.0 & 189.0 & 182.0 & 248.0 & 216.0 & 152.0 & 245.0 & $2239 . \odot$ \\
\hline 1981 & 2 & 01 & 42.0 & 117.0 & 207.0 & 330.0 & 313.0 & 339.0 & 169.0 & 213.0 & 215.0 & 239.0 & 139.0 & 189.0 & $2512 . \odot$ \\
\hline 1982 & 2 & 01 & 193.0 & 132.0 & 115.0 & 241.0 & 191.0 & 154.0 & 212.0 & 108.0 & 130.0 & & & 54.03 & 1530.0 \\
\hline 1983 & 2 & 01 & 5.0 & 30.0 & 141.0 & 231.0 & 169.0 & 159.0 & 312.0 & 264.0 & 251.0 & 259.0 & 159.0 & 207.0 & 2187.0 \\
\hline 1984 & 2 & 01 & 255.0 & 232.0 & 96.0 & 194.0 & 195.4 & 331.9 & 240.0 & 157.0 & 272.0 & 278.0 & 377.9 & 144.0 & 2773.2 \\
\hline 1985 & 2 & 01 & 133.0 & 39.0 & 130.0 & 111.0 & 230.0 & 106.0 & 160.0 & 359.0 & 195.0 & 205.0 & 150.0 & 151.0 & 1969.0 \\
\hline 1986 & 2 & 01 & 181.0 & 63.0 & $200 . \odot$ & 334.0 & 365.0 & 279.0 & 97.0 & 135.0 & 172.0 & 270.0 & 166.0 & 68.0 & 2330.0 \\
\hline 1987 & 2 & 01 & 92.0 & 64.0 & 144.0 & 150.0 & 248.0 & 114.0 & 345.0 & 226.0 & 206.0 & 320.0 & 170.0 & 110.0 & 2189.0 \\
\hline 1988 & 1 & 01 & 70.0 & 149.0 & 38.0 & 154.0 & 284.0 & 192.6 & 375.0 & 319.0 & 286.0 & 432.0 & 292.0 & 220.0 & 2811.6 \\
\hline 1989 & 2 & 01 & 197.0 & 121.0 & 118.0 & 215.0 & 287.0 & 235.0 & 154.0 & 253.0 & 243.0 & 255.0 & 207.0 & 99.0 & 2384.0 \\
\hline 1990 & 1 & 01 & 110.0 & 170.0 & 97.0 & & & & & 142.0 & 174.03 & 305.0 & 247.0 & 113.0 & 1358.0 \\
\hline 1991 & 1 & 01 & 33.0 & 155.0 & 144.0 & 86.0 & 267.0 & 212.0 & 151.2 & 51.0 & 177.0 & 178.0 & 270.0 & 117.0 & 1841.2 \\
\hline 1992 & 1 & 01 & 11.0 & 36.0 & 87.0 & 87.0 & 321.0 & 135.0 & 171.0 & 99.0 & 148.0 & 152.0 & 115.0 & 93.0 & 1455.0 \\
\hline 1993 & 1 & 01 & 208.0 & 75.0 & 176.0 & 196.0 & 313.0 & 191.0 & 222.0 & 135.0 & 251.0 & 191.0 & 190.0 & 134.03 & 2282.0 \\
\hline 1994 & 1 & 01 & 112.0 & 155.0 & 137.0 & 231.0 & 254.0 & 220.1 & 102.0 & 230.0 & 172.0 & 255.0 & 317.0 & 55.0 & 2240.1 \\
\hline 1995 & 1 & 01 & .0 & 44.0 & 69.0 & 205.0 & 262.0 & 385.0 & 646.0 & 282.0 & 225.0 & 203.03 & 108.7 & 188.0 & 2617.7 \\
\hline 1996 & 1 & 01 & 105.0 & 101.1 & 290.0 & 296.0 & 243.0 & 460.0 & 625.0 & 176.0 & 237.0 & 348.0 & 153.0 & 141.0 & 3175.1 \\
\hline 1997 & 1 & 01 & 235.0 & 208.0 & 163.0 & 199.0 & 146.0 & 163.0 & 84.0 & 55.0 & 128.0 & 236.0 & 185.0 & $20 . \odot$ & 1822.0 \\
\hline 1998 & 1 & 01 & 47.0 & 62.0 & 119.0 & 164.0 & 311.0 & 285.0 & 279.0 & 328.0 & 227.0 & 205.0 & 232.0 & 249.0 & $2508 . \odot$ \\
\hline 1999 & 1 & 01 & 239.0 & 253.0 & 239.0 & 230.0 & 278.0 & 261.0 & 212.0 & 298.0 & 405.0 & 233.0 & 619.0 & 228.0 & 3495.0 \\
\hline 2000 & 1 & 01 & 253.0 & 237.0 & 105.0 & 242.0 & 307.0 & 282.0 & & & & & & & 1426.0 \\
\hline
\end{tabular}


MEDIOS

MAXIMOS

$\begin{array}{rrrrr}125.0 & 121.1 & 137.0 & 203.7 & 266.3 \\ 255.0 & 253.0 & 290.0 & 334.0 & 365 .\end{array}$

$\begin{array}{llllll}666.3 & 236.2 & 249.7 & 200.6 & 218.1 & 251.6\end{array}$

30.0

38.0

86.0

460.0

646.

359.

405.0

432.0

$223.7 \quad 141.3$

$619.0 \quad 249.0$

2374.3

$51.0 \quad 128.0$

152.0

108.7

20.0

0.0
0.0 
I D E A M - INSTITUTO DE HIDROLOGIA, METEOROLOGIA Y ESTUdios AMBIENTALES VALORES MAXIMOS MENSUALES DE PRECIPITACION (mms)

SISTEMA DE INFORMACION NACIONAL AMBIENTAL

FECHA DE PROCESO : 2001/08/23 EN 24 HORAS

ESTACION : 1102001 CARMEN DE ATRATO

$\begin{array}{lllllll}\text { LATITUD } & 0554 \mathrm{~N} & \text { TIPO EST } & \text { PM } & & \text { DEPTO } & \text { CHOCO } \\ \text { LONGITUD } & 7612 \mathrm{~W} & \text { ENTIDAD } & 01 & \text { IDEAM } & \text { MUNICIPIO } & \text { EL CARMEN } \\ \text { ELEVACION } & 1850 \mathrm{~m} . \mathrm{s} . \mathrm{n} . \mathrm{m} & \text { REGIONAL } & 01 & \text { ANTIOQUIA } & \text { CORRIENTE } & \text { ATRATO }\end{array}$

FECHA-INSTALACION 1958-OCT FECHA-SUSPENSION

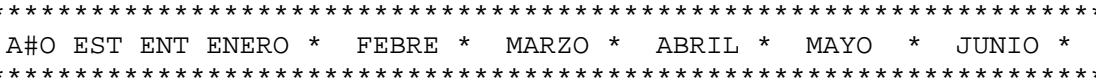

\begin{tabular}{|c|c|c|c|c|c|c|c|c|c|c|c|c|c|c|c|}
\hline 1980 & 2 & 01 & 38.0 & 33.0 & 30.0 & 45.0 & 75.0 & 45.0 & 32.0 & 53.0 & 34.0 & 28.0 & 15.0 & 40.0 & 75.0 \\
\hline 1981 & 2 & 01 & 15.0 & 28.0 & 40.0 & 50.0 & 51.0 & 70.0 & 23.0 & 46.0 & 40.0 & 40.0 & 15.0 & 34.0 & 70.0 \\
\hline 1982 & 2 & 01 & 35.0 & 34.0 & 30.0 & 45.0 & 30.0 & 50.0 & 50.0 & 37.0 & 41.0 & & & 23.0 & 50.0 \\
\hline 1983 & 2 & 01 & 2.0 & 12.0 & 20.0 & 32.0 & 26.0 & 27.0 & 53.0 & 47.0 & 61.0 & 40.0 & 26.0 & 22.0 & 61.0 \\
\hline 1984 & 2 & 01 & 45.0 & 30.0 & 24.0 & 34.0 & 28.0 & 25.8 & 34.0 & 29.0 & 66.0 & 39.0 & 60.0 & 33.0 & 66.0 \\
\hline 1985 & 2 & 01 & 28.0 & 15.0 & 32.0 & 23.0 & 32.0 & 30.0 & 24.0 & 34.0 & 29.0 & 26.0 & 25.0 & 20.0 & 34.0 \\
\hline 1986 & 2 & 01 & & 35.0 & 34.0 & 65.0 & 65.0 & 70.0 & 55.0 & 27.0 & 35.0 & $4 \odot . \odot$ & 36.0 & 14.0 & 70.0 \\
\hline 1987 & 2 & 01 & 25.0 & 27.0 & 34.0 & 23.0 & 27.0 & 35.0 & 40.0 & 35.0 & 29.0 & 33.0 & 37.0 & 20.0 & 40.0 \\
\hline 1988 & 1 & 01 & 20.0 & 60.0 & 16.0 & 17.0 & 30.0 & 40.0 & 35.0 & 40.0 & 35.0 & 64.0 & 50.0 & 31.0 & 64.0 \\
\hline 1989 & 2 & 01 & 20.0 & 25.0 & 20.0 & 44.0 & 30.0 & 26.0 & 20.0 & 44.0 & 36.0 & 37.0 & 25.0 & 30.0 & 44.0 \\
\hline 1990 & 1 & 01 & 21.0 & 50.0 & 17.0 & & & & & 20.0 & 24.03 & 40.0 & 30.0 & 15.0 & 50.0 \\
\hline 1991 & 1 & 01 & 10.0 & 55.0 & 33.0 & 18.0 & 40.0 & 18.0 & 32.0 & 20.0 & 34.0 & 45.0 & 58.0 & 31.0 & 58.0 \\
\hline 1992 & 1 & 01 & 6.0 & 16.0 & 42.0 & 20.0 & 60.0 & 32.0 & 20.0 & 25.0 & 20.0 & 23.0 & 30.0 & 16.0 & 60.0 \\
\hline 1993 & 1 & 01 & 58.0 & 17.0 & 39.0 & 74.0 & 39.0 & 50.0 & 50.0 & 20.0 & 29.0 & 30.0 & 50.0 & 47.0 & 74.0 \\
\hline 1994 & 1 & 01 & 22.0 & 70.0 & 30.0 & $25 . \odot$ & 37.0 & 34.0 & 20.0 & 35.0 & 34.0 & 57.0 & 60.0 & 23.0 & 70.0 \\
\hline 1995 & 1 & 01 & .0 & 31.0 & 17.0 & 30.0 & 35.0 & 78.0 & 90.0 & 70.0 & 25.0 & 35.03 & 27.0 & 32.0 & 90.0 \\
\hline 1996 & 1 & 01 & 17.0 & 31.0 & 37.0 & 53.0 & 45.0 & 60.0 & 70.0 & 28.0 & 66.0 & 38.0 & 31.0 & 36.0 & 70.0 \\
\hline 1997 & 1 & 01 & 27.0 & 50.0 & 45.0 & 33.0 & 55.0 & 20.0 & 34.0 & 17.0 & 24.0 & 43.0 & 38.0 & 8.0 & 55.0 \\
\hline 1998 & 1 & 01 & 15.0 & 16.0 & 33.0 & 26.0 & 45.0 & 41.0 & 28.0 & 36.0 & 23.0 & 27.0 & 30.0 & 26.0 & 45.0 \\
\hline 1999 & 1 & 01 & 38.0 & 53.0 & 30.0 & 34.0 & 27.0 & 35.0 & 25.0 & 35.0 & 36.0 & 19.0 & 78.0 & 40.0 & 78.0 \\
\hline 2000 & 1 & 01 & 50.0 & 31.0 & 17.0 & 27.0 & 40.0 & 33.0 & & & & & & & 50.0 \\
\hline IEDIOS & & & 24.6 & 34.2 & 29.5 & 35.9 & 40.9 & 41.0 & 38.7 & 34.9 & 36.1 & 37.1 & 37.9 & 27.1 & 34.8 \\
\hline IAXIMOS & & & 58.0 & 70.0 & 45.0 & 74.0 & 75.0 & 78.0 & 90.0 & 70.0 & 66.0 & 64.0 & 78.0 & 47.0 & $90 . \odot$ \\
\hline INIMOS & & & $\odot . \odot$ & 12.0 & 16.0 & 17.0 & 26.0 & 18.0 & 20.0 & 17.0 & 20.0 & 19.0 & 15.0 & 8.0 & $\odot . \odot$ \\
\hline
\end{tabular}

* $\quad$ C O N VENCIONES* * 
* * AUSENCIAS DE DATO **

1 : Preliminares Ideam

: Definitivos Ideam

3: Preliminares 0tra Entidad

4: Definitivos otra Entidad
1 : Ausencia del observ : Desperfecto instru.

Dato rechazado

: Nivel superior

: Nivel inferior

8 : Curva de gastos

9 : Seccion inestable

A : Instr. sedimentado

M : Maximo no extrapol

* : Datos insuficientes
* * ORIGENES DE DATO * *

1 : Registrados

: Incompletos

4 : Dudosos

: Est. Regresion

: Est. Interpolacion

: Est. otros metodos 
Anexo 2. Localização e conteúdo de elementos exploradores em sedimentos ativos.

\begin{tabular}{|c|c|c|c|c|c|c|c|c|c|}
\hline \multicolumn{2}{|c|}{ COORDENADAS Este-Norte } & \multicolumn{2}{|c|}{ Ppm CHUMBO } & \multicolumn{2}{|c|}{ Ppm ZINCO } & \multicolumn{2}{|c|}{ Ppm OURO } & \multicolumn{2}{|c|}{ PpM PRATA } \\
\hline 1102482.3469647 & 1149849.0116386 & 21.9 & "Pb" & 128.3 & "Zn" & 0 & "Au" & 0.32 & "Ag" \\
\hline 1102762.7635255 & 1149710.0129318 & 0 & "Pb" & 135.6 & "Zn" & "nd" & "Au" & 0.3 & "Ag" \\
\hline 1102809.0932182 & 1149339.3497137 & 58.2 & "Pb" & 155.1 & "Zn" & 0 & "Au" & 1.03 & "Ag" \\
\hline 1102974.9047498 & 1149212.5438759 & 50.3 & "Pb" & 117.6 & "Zn" & 0 & "Au" & 1.55 & "Ag" \\
\hline 1103126.0858522 & 1149124.7552189 & 20.7 & "Pb" & 116.3 & "Zn" & 0 & "Au" & 0.63 & "Ag" \\
\hline 1103584.505969 & 1149171.0881212 & 0 & "Pb" & 0 & "Zn" & "nd" & "Au" & 0 & "Ag" \\
\hline 1103555.2451105 & 1149249.1224829 & 0 & "Pb" & 0 & "Zn" & 18.3 & "Au" & 0 & "Ag" \\
\hline 1103547.9298959 & 1149293.0168114 & 0 & "Pb" & 116.8 & "Zn" & "nd" & "Au" & 0.2 & "Ag" \\
\hline 1103674.7269495 & 1149814.8716054 & 0 & "Pb" & 316.9 & "Zn" & "nd" & "Au" & 1.1 & "Ag" \\
\hline 1104910.998222 & 1149712.4515056 & 0 & "Pb" & 110.7 & "Zn" & 0 & "Au" & nd & "Ag" \\
\hline 1104847.5996952 & 1149353.9811565 & 0 & "Pb" & 158.7 & "Zn" & 0 & "Au" & 0.6 & "Ag" \\
\hline 1104852.476505 & 1149266.1924995 & 13.3 & "Pb" & 163.5 & "Zn" & 0.123 & "Au" & 0.36 & "Ag" \\
\hline 1104901.2446025 & 1149224.7367449 & 11.7 & "Pb" & 110.4 & "Zn" & 0.106 & "Au" & 0.16 & "Ag" \\
\hline 1104998.7807976 & 1149188.1581378 & 0 & "Pb" & 87 & "Zn" & 0 & "Au" & nd & "Ag" \\
\hline 1106425.2476505 & 1149807.555884 & 10 & "Pb" & 72 & "Zn" & 0 & "Au" & 1 & "Ag" \\
\hline 1106500.8382017 & 1149846.5730648 & 16 & "Pb" & 101 & "Zn" & 0 & "Au" & 1 & "Ag" \\
\hline 1103633.2740665 & 1148324.9030113 & 14.1 & "Pb" & 130 & "Zn" & 0 & "Au" & 0.33 & "Ag" \\
\hline 1103747.8790958 & 1148561.4446702 & 0 & "Pb" & 0 & "Zn" & 0 & "Au" & 0 & "Ag" \\
\hline 1103803.9624079 & 1148505.3574728 & 10.6 & "Pb" & 148.5 & "Zn" & 0 & "Au" & 0.2 & "Ag" \\
\hline 1103838.1000762 & 1148517.5503418 & 0 & "Pb" & 0 & "Zn" & 0 & "Au" & 1 & "Ag" \\
\hline 1103894.1833884 & 1148110.3085165 & 19.3 & "Pb" & 139.2 & "Zn" & 0 & "Au" & 0.39 & "Ag" \\
\hline 1104079.502159 & 1148646.7947534 & 9.8 & "Pb" & 97.1 & "Zn" & 0 & "Au" & 0.21 & "Ag" \\
\hline 1104347.7266955 & 1148905.2835766 & 16.1 & "Pb" & 182.7 & "Zn" & 0 & "Au" & 0.57 & "Ag" \\
\hline 1104376.987554 & 1148712.6362461 & 13.8 & "Pb" & 137.7 & "Zn" & 0.445 & "Au" & 0.5 & "Ag" \\
\hline 1104779.3243586 & 1148307.8329946 & 0 & "Pb" & 102.8 & "Zn" & 0.28 & "Au" & nd & "Ag" \\
\hline 1104650.0889002 & 1148005.449843 & 0 & "Pb" & 0 & "Zn" & 0 & "Au" & 0 & "Ag" \\
\hline 1105123.1394463 & 1148083.4842047 & 0 & "Pb" & 91.4 & "Zn" & 0 & "Au" & nd & "Ag" \\
\hline 1107039.7256795 & 1148305.3944208 & 7.8 & "Pb" & 56.7 & "Zn" & 0 & "Au" & 0.15 & "Ag" \\
\hline 1107022.6568453 & 1147995.6955478 & 10.1 & "Pb" & 77.5 & "Zn" & 0.11 & "Au" & 0.15 & "Ag" \\
\hline 1107032.4104648 & 1147339.7191945 & 8.1 & "Pb" & 71.4 & "Zn" & 0.07 & "Au" & 0.15 & "Ag" \\
\hline
\end{tabular}




\begin{tabular}{|c|c|c|c|c|c|c|c|c|c|}
\hline 1107115.3162306 & 1147042.2131905 & 9.2 & "Pb" & 89.6 & "Zn" & 0.05 & "Au" & 0.15 & "Ag" \\
\hline 1107010.4648209 & 1147300.7020137 & 10.9 & "Pb" & 96.8 & "Zn" & 0.05 & “Au" & 0.15 & "Ag" \\
\hline 1106591.0591821 & 1147256.8076852 & 8.6 & "Pb" & 52.5 & "Zn" & 0 & "Au" & 0.15 & "Ag" \\
\hline 1106537.4142748 & 1147315.3334565 & 10.6 & "Pb" & 102 & "Zn" & 0 & "Au" & 0.15 & "Ag" \\
\hline 1106105.8166116 & 1147451.8935895 & 10.1 & "Pb" & 118.5 & "Zn" & "nd". & "Au" & 0.15 & "Ag" \\
\hline 1105942.4434849 & 1147805.4867911 & 12.4 & "Pb" & 104 & "Zn" & 0.05 & "Au" & 0.15 & "Ag" \\
\hline 1105920.497841 & 1147768.908184 & 12.4 & "Pb" & 112.6 & "Zn" & 0.05 & "Au" & 0.15 & "Ag" \\
\hline 1105198.7299975 & 1147888.3983004 & 0 & "Pb" & 106.5 & "Zn" & 0 & "Au" & 0.3 & "Ag" \\
\hline 1105052.4257049 & 1147942.0469241 & 0 & "Pb" & 109.2 & "Zn" & 0 & "Au" & 0.3 & "Ag" \\
\hline 1104891.490983 & 1147781.101053 & 12.2 & "Pb" & 115.2 & "Zn" & 0 & “Au” & 0.15 & "Ag" \\
\hline 1104862.2301245 & 1147773.7853316 & 38.7 & "Pb" & 294.5 & "Zn" & 5.164 & "Au” & 1.41 & "Ag" \\
\hline 1104806.1468123 & 1147754.2767412 & 68.7 & "Pb" & 137.3 & "Zn" & 0.072 & "Au" & 2.08 & "Ag" \\
\hline 1104762.2555245 & 1147725.0138555 & 13.8 & "Pb & 132.4 & "Zn" & 0 & "Au" & 0.26 & "Ag" \\
\hline 1104706.1722123 & 1147720.1367079 & 10.1 & "Pb" & 72.2 & "Zn" & 0 & "Au" & 0.15 & "Ag" \\
\hline 1104486.7157734 & 1147749.3995936 & 41.8 & "Pb" & 167.5 & "Zn" & 0.459 & "Au" & 1.23 & "Ag" \\
\hline 1104501.3462027 & 1147707.9438389 & 19.9 & "Pb" & 128.2 & "Zn" & 1.075 & "Au" & 0.39 & "Ag" \\
\hline 1104213.6144272 & 1147507.980787 & 0 & "Pb" & 0 & "Zn" & 1.1 & "Au" & 0 & "Ag" \\
\hline 1104179.476759 & 1147473.8407537 & 0 & "Pb" & 0 & "Zn" & 0 & "Au" & 1 & "Ag" \\
\hline 1104157.5311151 & 1147434.8235729 & 0 & "Pb" & 97.1 & "Zn" & 0.35 & "Au" & 0.2 & "Ag" \\
\hline 1103974.6507493 & 1147942.0469241 & 17.2 & "Pb" & 130.6 & "Zn" & 0 & "Au" & 0.43 & "Ag" \\
\hline 1103860.0457201 & 1147881.082579 & 15.2 & "Pb" & 131.4 & "Zn" & 0 & "Au" & 0.22 & "Ag" \\
\hline 1103426.009652 & 1147693.3123961 & 15.9 & "Pb" & 140.2 & "Zn" & 0 & "Au" & 0.42 & "Ag" \\
\hline 1103218.7452375 & 1147749.3995936 & 14 & "Pb" & 110 & "Zn" & 0 & "Au" & 1 & "Ag" \\
\hline 1103204.1148082 & 1147710.3824127 & 13.1 & "Pb" & 125.8 & "Zn" & 0 & "Au" & 0.28 & "Ag" \\
\hline 1103152.9083058 & 1147705.5052651 & 15.1 & "Pb" & 141.1 & "Zn" & 0.05 & "Au" & 0.4 & "Ag" \\
\hline 1102809.0932182 & 1147907.9068908 & 13.4 & "Pb" & 131 & "Zn" & 0.05 & "Au" & 0.18 & "Ag" \\
\hline 1102762.7635255 & 1147898.1525956 & 17.6 & "Pb" & 128.5 & "Zn" & 0 & "Au" & 0.36 & "Ag" \\
\hline 1102760.3251207 & 1147849.3811195 & 14 & "Pb" & 121.3 & "Zn" & 0 & "Au" & 0.15 & "Ag" \\
\hline 1104250.1905004 & 1147093.4232403 & 15 & "Pb" & 185.7 & "Zn" & 10.12 & "Au" & 0.91 & "Ag" \\
\hline 1104698.8569977 & 1147039.7746167 & 0 & "Pb" & 0 & "Zn" & 0 & "Au" & 0 & "Ag" \\
\hline 1104889.0525781 & 1147195.8433401 & 0 & "Pb" & 0 & "Zn" & 0 & "Au" & 0 & "Ag" \\
\hline 1105010.9728219 & 1147225.1062258 & 0 & "Pb" & 0 & "Zn" & 0 & "Au" & 0 & "Ag" \\
\hline 1105037.7952756 & 1147215.3519305 & 0 & "Pb" & 0 & "Zn" & 0 & "Au" & 0 & "Ag" \\
\hline 1105154.8387097 & 1147193.4047663 & 5.9 & "Pb" & 50.9 & "Zn" & 0 & "Au" & 0.15 & "Ag" \\
\hline 1103830.7848616 & 1146000.9421762 & 0 & "Pb" & 0 & "Zn" & 0 & "Au" & 1 & "Ag" \\
\hline
\end{tabular}




\begin{tabular}{|c|c|c|c|c|c|c|c|c|c|}
\hline 1103918.5674371 & 1146252.115278 & 15.4 & "Pb" & 104.5 & "Zn" & 0 & "Au" & 0.96 & "Ag" \\
\hline 1103762.509525 & 1146356.9739516 & 11.8 & "Pb" & 104.7 & "Zn" & 0 & "Au" & 0.18 & "Ag" \\
\hline 1103743.002286 & 1146647.1642343 & 38 & "Pb" & 132.7 & "Zn" & 0 & "Au" & 1.13 & "Ag" \\
\hline 1103777.1399543 & 1146683.7428413 & 18.6 & "Pb" & 140.8 & "Zn" & 0 & "Au" & 0.62 & "Ag" \\
\hline 1105279.1973584 & 1146278.9395899 & 0 & "Pb" & 100.1 & "Zn" & 0 & "Au" & nd & "Ag" \\
\hline 1105815.6464313 & 1146637.409939 & 0 & "Pb" & 19.9 & "Zn" & 0 & "Au" & 0.3 & "Ag" \\
\hline 1105810.7696215 & 1146773.970072 & 0 & "Pb" & 22.8 & "Zn" & 0 & "Au" & 1.2 & "Ag" \\
\hline 1105849.7840996 & 1146820.3029743 & 0 & "Pb" & 63.2 & "Zn" & 0 & "Au" & 1.6 & "Ag" \\
\hline 1105881.483363 & 1146693.4971365 & 0 & "Pb" & 0 & "Zn" & 0 & "Au" & 0 & "Ag" \\
\hline 1106113.1318263 & 1146844.6887124 & 0 & "Pb" & 39.1 & "Zn" & 0 & "Au" & 0.4 & "Ag" \\
\hline 1106305.7658115 & 1146600.831332 & 0 & "Pb" & 190.2 & "Zn" & 0 & "Au" & nd & "Ag" \\
\hline 1106347.2186944 & 1146530.1126917 & 0 & "Pb" & 121 & "Zn" & 0 & "Au" & nd & "Ag" \\
\hline 1107205.5372111 & 1146766.6543506 & 11.4 & "Pb" & 92.8 & "Zn" & 0.109 & "Au" & 0.15 & "Ag" \\
\hline 1107246.990094 & 1146598.3927582 & 11 & "Pb" & 119 & "Zn" & 0.05 & "Au" & 0.15 & "Ag" \\
\hline 1107693.2181864 & 1146527.6741179 & 62 & "Pb" & 105 & "Zn" & 0 & "Au" & 2 & "Ag" \\
\hline 1107766.3703327 & 1146442.3240347 & 14 & "Pb" & 92 & "Zn" & 0 & "Au" & 1 & "Ag" \\
\hline 1107710.2870206 & 1146381.3596896 & 11.4 & "Pb" & 74.1 & "Zn" & "nd" & "Au" & nd & "Ag" \\
\hline 1107546.9138938 & 1146061.9065213 & 8.4 & "Pb" & 76.8 & "Zn" & 0.18 & "Au" & 0.15 & "Ag" \\
\hline 1102467.7165354 & 1146049.7136523 & 13.4 & "Pb" & 112.7 & "Zn" & 0.05 & "Au" & 0.26 & "Ag" \\
\hline 1102016.6116332 & 1145610.7703676 & 10.5 & "Pb" & 105.2 & "Zn" & 0.05 & "Au" & 0.16 & "Ag" \\
\hline 1102050.7493015 & 1145464.4559394 & 8.6 & "Pb" & 74.5 & "Zn" & 0.05 & "Au" & 0.15 & "Ag" \\
\hline 1102499.4157988 & 1145493.7188251 & 10.3 & "Pb" & 105.4 & "Zn" & 0.05 & "Au" & 0.18 & "Ag" \\
\hline 1103572.3139446 & 1145925.3463883 & 29.9 & "Pb" & 131.9 & "Zn" & 0 & "Au" & 0.95 & "Ag" \\
\hline 1103582.0675641 & 1145105.9855902 & 8.2 & "Pb" & 75.1 & "Zn" & 0.05 & "Au" & 0.15 & "Ag" \\
\hline 1104350.1651003 & 1145837.5577314 & 18.1 & "Pb" & 124.6 & "Zn" & 0 & "Au" & 0.45 & "Ag" \\
\hline 1104379.4259589 & 1145881.4520599 & 23.3 & "Pb" & 169.2 & "Zn" & 0 & "Au" & 6.18 & "Ag" \\
\hline 1104654.9657099 & 1145978.995012 & 0 & "Pb" & 134.3 & "Zn" & "nd" & "Au" & nd & "Ag" \\
\hline 1104798.8315977 & 1145888.7677813 & 0 & "Pb" & 164.8 & "Zn" & "nd" & "Au" & 0.3 & "Ag" \\
\hline 1104811.023622 & 1145930.2235359 & 0 & "Pb" & 107.3 & "Zn" & "nd" & "Au" & nd & "Ag" \\
\hline 1106542.2910846 & 1145981.4335858 & 0 & "Pb" & 171.4 & "Zn" & 0 & "Au" & nd & "Ag" \\
\hline 1107471.3233426 & 1145978.995012 & 12.2 & "Pb" & 94.5 & "Zn" & 0.15 & "Au" & 0.15 & "Ag" \\
\hline 1107503.022606 & 1145727.8219102 & 17.6 & "Pb" & 31.3 & "Zn" & 0.15 & "Au" & 0.19 & "Ag" \\
\hline 1107585.9283719 & 1145215.7214114 & 10.8 & "Pb" & 88.5 & "Zn" & 0.05 & "Au" & 0.15 & "Ag" \\
\hline 1107561.5443231 & 1145115.7398855 & 7.7 & "Pb" & 87 & "Zn" & 0.27 & "Au" & 0.15 & "Ag" \\
\hline 1107295.7581915 & 1145637.5946795 & 11.4 & "Pb" & 102.1 & "Zn" & 0.08 & "Au" & 0.15 & "Ag" \\
\hline
\end{tabular}




\begin{tabular}{|c|c|c|c|c|c|c|c|c|c|}
\hline 1107229.9212598 & 1145561.9988916 & 8.5 & "Pb" & 113.5 & "Zn" & 0.05 & "Au" & 0.15 & "Ag" \\
\hline 1106652.019304 & 1145537.6131535 & $\cdot 0$ & "Pb" & 189.5 & "Zn" & 0 & "Au" & nd & "Ag" \\
\hline 1106681.2801626 & 1145335.2115278 & 0 & "Pb" & 242 & "Zn" & 0 & "Au" & 1.1 & "Ag" \\
\hline 1107898.0441961 & 1145020.6355071 & 14.7 & "Pb" & 111.8 & "Zn" & 0 & "Au" & 0.15 & "Ag" \\
\hline 1107973.6347473 & 1144845.0581932 & 12.7 & "Pb" & 128.7 & "Zn" & 0.05 & "Au" & 0.24 & "Ag" \\
\hline 1107927.3050546 & 1144667.0423056 & 15.9 & "Pb" & 50.6 & "Zn" & 0 & "Au" & 0.67 & "Ag" \\
\hline 1107983.3883668 & 1144552.4293368 & 15 & "Pb" & 48.3 & "Zn" & 0 & "Au" & 0.15 & "Ag" \\
\hline 1108058.978918 & 1144432.9392204 & 10.5 & "Pb" & 63.3 & "Zn" & 0.19 & "Au" & 0.15 & "Ag" \\
\hline 1108144.3230886 & 1144342.7119897 & 9.3 & "Pb" & 44.5 & "Zn" & 18.39 & "Au" & 0.15 & "Ag" \\
\hline 1108205.2832106 & 1144250.0461851 & 8.3 & "Pb" & 117.4 & "Zn" & 0.05 & "Au" & 0.15 & "Ag" \\
\hline 1108107.7470155 & 1144306.1333826 & 8.7 & "Pb" & 79 & "Zn" & 0.11 & "Au" & 0.15 & "Ag" \\
\hline 1108034.5948692 & 1144062.2760022 & 12.1 & "Pb" & 99 & "Zn" & 0.05 & "Au" & 0.15 & "Ag" \\
\hline 1107729.7942596 & 1144710.936634 & 8.2 & "Pb" & 106 & "Zn" & 0.10 & "Au" & 0.15 & "Ag" \\
\hline 1107566.4211328 & 1144201.274709 & 10.8 & "Pb" & 76.8 & "Zn" & 0 & "Au" & 0 & "Ag" \\
\hline 1106922.6822454 & 1144671.9194532 & 0 & "Pb" & 166.3 & "Zn" & 0 & "Au" & 0.3 & "Ag" \\
\hline 1106971.4503429 & 1144464.6406798 & 0 & "Pb" & 114.5 & "Zn" & 0 & "Au" & nd & "Ag" \\
\hline 1106571.5519431 & 1144298.8176612 & 0 & "Pb" & 132.1 & "Zn" & 0 & "Au" & nd & "Ag" \\
\hline 1105669.3421387 & 1144062.2760022 & 0 & "Pb" & 118.8 & "Zn" & 0 & "Au" & nd & "Ag" \\
\hline 1104181.9151638 & 1144596.3236653 & 0 & "Pb" & 0 & "Zn" & 0 & "Au" & 0 & "Ag" \\
\hline 1104835.4076708 & 1144715.8137816 & 12 & "Pb" & 106 & "Zn" & 0 & "Au" & 1 & "Ag" \\
\hline 1104820.7772416 & 1144669.4808794 & 0 & "Pb" & 125.2 & "Zn" & "nd" & "Au" & 0.3 & "Ag" \\
\hline 1104879.2989586 & 1144679.2351746 & 0 & "Pb" & 147 & "Zn" & "nd" & "Au" & 0.5 & "Ag" \\
\hline 1104930.505461 & 1144547.5521892 & 14 & "Pb" & 108 & "Zn" & 0 & "Au" & 1 & "Ag" \\
\hline 1104959.7663195 & 1144554.8679106 & 14 & "Pb" & 116 & "Zn" & 0 & "Au" & 1 & "Ag" \\
\hline 1105086.5633731 & 1144740.1995197 & 0 & "Pb" & 92 & "Zn" & "nd" & "Au" & nd & "Ag" \\
\hline 1105086.5633731 & 1144710.936634 & 0 & "Pb" & 110.3 & "Zn" & "nd" & "Au" & 1 & "Ag" \\
\hline 1105110.9474219 & 1144686.550896 & 14 & "Pb" & 100 & "Zn" & 0 & "Au" & 1 & "Ag" \\
\hline 1105115.8242316 & 1144757.2695363 & 16 & "Pb" & 78 & "Zn" & 0 & "Au" & 1 & "Ag" \\
\hline 1107488.3921768 & 1143984.2416405 & 7.5 & "Pb" & 68.3 & "Zn" & 0 & "Au" & 0.15 & "Ag" \\
\hline 1107966.3195326 & 1143423.3696656 & 86.9 & "Pb" & 147.8 & "Zn" & 0 & "Au" & 0.15 & "Ag" \\
\hline 1107849.2760986 & 1143225.8451875 & 11.6 & "Pb" & 84.7 & "Zn" & 0 & "Au" & 0.15 & "Ag" \\
\hline 1107802.9464059 & 1143267.3009422 & 7.8 & "Pb" & 79.9 & "Zn" & 0 & "Au" & 0.15 & "Ag" \\
\hline 1107656.6421133 & 1143735.5071125 & 11 & "Pb" & 41.1 & "Zn" & 0.07 & "Au" & 0.15 & "Ag" \\
\hline 1107512.7762256 & 1143525.7897654 & 9.7 & "Pb" & 133.9 & "Zn" & 0.05 & "Au" & 0.16 & "Ag" \\
\hline 1106969.011938 & 1143596.5084057 & 0 & "Pb" & 134.8 & "Zn" & 0 & "Au" & nd & "Ag" \\
\hline
\end{tabular}




\begin{tabular}{|c|c|c|c|c|c|c|c|c|c|}
\hline 1106976.3271527 & 1143645.2798818 & 0 & "Pb" & 167.6 & "Zn" & 0 & "Au" & nd & "Ag" \\
\hline 1105523.0378461 & 1143142.9336782 & 11.3 & "Pb" & 132.2 & "Zn" & 0 & "Au" & 0.17 & "Ag" \\
\hline 1105479.1465583 & 1143084.4079069 & 12.7 & "Pb" & 131.7 & "Zn" & 0 & "Au" & 0.16 & "Ag" \\
\hline 1103523.5458471 & 1143920.8387216 & 10.6 & "Pb" & 78.4 & "Zn" & 0 & "Au" & 0.17 & "Ag" \\
\hline 1103504.0386081 & 1143842.8043599 & 17.1 & "Pb" & 116.7 & "Zn" & 0 & "Au" & 0.39 & "Ag" \\
\hline 1103472.3393447 & 1143591.6312581 & 0 & "Pb" & 0 & "Zn" & 0 & "Au" & 0 & "Ag" \\
\hline 1103435.7632715 & 1143352.6510253 & 11.6 & "Pb" & 85.1 & "Zn" & 0 & "Au" & 0.3 & "Ag" \\
\hline 1103260.1981204 & 1143774.5242934 & 21.7 & "Pb" & 87.9 & "Zn" & 0 & "Au" & 0.56 & "Ag" \\
\hline 1103369.9263399 & 1142699.1132459 & 11 & "Pb" & 96.7 & "Zn" & 0 & "Au" & 0.15 & "Ag" \\
\hline 1103240.6908814 & 1142382.0986514 & 14.7 & "Pb" & 96.7 & "Zn" & 0.05 & "Au" & 0.15 & "Ag" \\
\hline 1103306.5278131 & 1142008.9968594 & 8.3 & "Pb" & 84.6 & "Zn" & 0.05 & "Au" & 0.15 & "Ag" \\
\hline 1103121.2090424 & 1142194.3284685 & 13.5 & "Pb" & 99.7 & "Zn" & 0 & "Au" & 0.17 & "Ag" \\
\hline 1105245.0596901 & 1142162.6270091 & 7.1 & "Pb" & 67.6 & "Zn" & 0 & "Au" & 0.15 & "Ag" \\
\hline 1105325.5270511 & 1142274.801404 & 7.9 & "Pb" & 80.6 & "Zn" & 0 & "Au" & 0.15 & "Ag" \\
\hline 1105347.4726949 & 1142496.7116202 & 11 & "Pb" & 112.9 & "Zn" & 0 & "Au" & 0.19 & "Ag" \\
\hline 1105320.6502413 & 1142516.2202106 & 8.7 & "Pb" & 87.7 & "Zn" & 0 & "Au" & 0.15 & "Ag" \\
\hline 1105269.4437389 & 1142567.4302605 & 8.1 & "Pb" & 73.2 & "Zn" & 0 & "Au" & 0.15 & "Ag" \\
\hline 1105276.7589535 & 1142733.2532791 & 10.4 & "Pb" & 87.4 & "Zn" & 0 & "Au" & 0.15 & "Ag" \\
\hline 1105347.4726949 & 1142830.7962313 & 9.2 & "Pb" & 97.6 & "Zn" & 0 & "Au" & 0.15 & "Ag" \\
\hline 1105515.7226314 & 1142916.1463144 & 6.1 & "Pb" & 63.4 & "Zn" & 0 & "Au" & 0.15 & "Ag" \\
\hline 1105708.3566167 & 1142116.2941068 & 0 & "Pb" & 120 & "Zn" & "nd" & "Au" & nd & "Ag" \\
\hline 1105974.1427483 & 1142235.7842232 & 0 & "Pb" & 119.8 & "Zn" & "nd" & "Au" & nd & "Ag" \\
\hline 1105993.6499873 & 1142343.0814705 & 0 & "Pb" & 81.1 & "Zn" & "nd" & "Au" & nd & "Ag" \\
\hline 1106149.7078994 & 1142425.9929799 & 0 & "Pb" & 70.8 & "Zn" & 0 & "Au" & nd & "Ag" \\
\hline 1106210.6680213 & 1142477.2030297 & 0 & "Pb" & 0 & "Zn" & 0 & "Au" & nd & "Ag" \\
\hline 1106169.2151384 & 1142513.7816368 & 0 & "Pb" & 55.1 & "Zn" & 0 & "Au" & nd & "Ag" \\
\hline 1106308.2042164 & 1142525.9745058 & 0 & "Pb" & 108.3 & "Zn" & "nd" & "Au" & nd & "Ag" \\
\hline 1106291.1353823 & 1142557.6759653 & 0 & "Pb" & 88 & "Zn" & 0 & "Au" & nd & "Ag" \\
\hline 1106944.6278893 & 1142928.3391834 & 0 & "Pb" & 296.4 & "Zn" & 0 & "Au" & 0.9 & "Ag" \\
\hline 1106966.5735331 & 1142955.1634953 & 0 & "Pb" & 317.9 & "Zn" & 0 & "Au" & 1.5 & "Ag" \\
\hline 1106866.5989332 & 1142286.994273 & 0 & "Pb" & 340 & "Zn" & 0 & "Au" & 1.3 & "Ag" \\
\hline 1106856.8453137 & 1142252.8542398 & 0 & "Pb" & 127.2 & "Zn" & 0 & "Au" & nd & "Ag" \\
\hline 1107061.6713233 & 1142165.0655829 & 0 & "Pb" & 96.3 & "Zn" & 0 & "Au" & nd & "Ag" \\
\hline 1107064.1097282 & 1142211.3984851 & 0 & "Pb" & 130 & "Zn" & 0.3 & "Au" & nd & "Ag" \\
\hline 1107110.4394209 & 1142894.1991502 & 11.9 & "Pb" & 306.6 & "Zn" & 0.05 & "Au" & 0.72 & "Ag" \\
\hline
\end{tabular}




\begin{tabular}{|c|c|c|c|c|c|c|c|c|c|}
\hline 1107227.482855 & 1142152.8727138 & 15.5 & "Pb" & 135 & "Zn" & 0.144 & "Au" & 0.33 & "Ag" \\
\hline 1107707.8486157 & 1142230.9070756 & 8.7 & "Pb" & 89.3 & "Zn" & 0.1 & "Au" & 0.15 & "Ag" \\
\hline 1107517.6530353 & 1142981.9878071 & 8.4 & "Pb" & 62.7 & "Zn" & 0 & "Au" & 0.15 & "Ag" \\
\hline 1107732.2326645 & 1142252.8542398 & 10.2 & "Pb" & 93.9 & "Zn" & 0 & "Au" & 0.15 & "Ag" \\
\hline 1107632.2580645 & 1142677.1660817 & 9.1 & "Pb" & 75.9 & "Zn" & 0 & "Au" & 0.15 & "Ag" \\
\hline 1107712.7254255 & 1142286.994273 & 16 & "Pb" & 90.4 & "Zn" & 56.369 & "Au" & 0.8 & "Ag" \\
\hline 1103274.8285497 & 1141404.2305561 & 12.2 & "Pb" & 99.7 & "Zn" & 0.05 & "Au" & 0.15 & "Ag" \\
\hline 1105254.8133096 & 1141811.4723813 & 12.3 & "Pb" & 77.4 & "Zn" & 0 & "Au" & nd & "Ag" \\
\hline 1105267.005334 & 1141684.6665435 & 7.1 & "Pb" & 61.6 & "Zn" & 0 & "Au" & nd & "Ag" \\
\hline 1105240.1828804 & 1141523.7206725 & 9.2 & "Pb" & 60.3 & "Zn" & 0 & "Au" & 0.15 & "Ag" \\
\hline 1105247.498095 & 1141384.7219656 & 8.9 & "Pb" & 62.5 & "Zn" & 0 & "Au" & 0.15 & "Ag" \\
\hline 1105359.6647193 & 1141950.4710881 & 9.3 & "Pb" & 78.2 & "Zn" & 0.05 & "Au" & nd & "Ag" \\
\hline 1105391.3639827 & 1141896.8224644 & 11.6 & "Pb" & 83.1 & "Zn" & 0 & "Au" & 0.15 & "Ag" \\
\hline 1105654.7117094 & 1141896.8224644 & 0 & "Pb" & 108.7 & "Zn" & 0.03 & "Au" & 0.2 & "Ag" \\
\hline 1105569.3675387 & 1141348.1433586 & 000 & "Pb" & 117.1 & "Zn" & "nd" & "Au" & 0.3 & "Ag" \\
\hline 1105501.0922022 & 1141045.7602069 & 11.9 & "Pb" & 102.4 & "Zn" & 0 & "Au" & 0.26 & "Ag" \\
\hline 1105618.1356363 & 1141077.4616664 & 10.6 & "Pb" & 81.2 & "Zn" & 0 & "Au" & 0.16 & "Ag" \\
\hline 1105635.2044704 & 1141104.2859782 & 12.3 & "Pb" & 92.6 & "Zn" & 0 & "Au" & 0.18 & "Ag" \\
\hline 1105803.4544069 & 1141406.6691299 & 0 & "Pb" & 112.3 & "Zn" & 0.02 & "Au" & 0.2 & "Ag" \\
\hline 1105925.3746507 & 1141453.0020321 & 0 & "Pb" & 90.8 & "Zn" & "nd" & "Au" & 0.2 & "Ag" \\
\hline 1105849.7840996 & 1141296.9333087 & 0 & "Pb" & 69.1 & "Zn" & 0 & "Au" & nd & "Ag" \\
\hline 1105942.4434849 & 1141294.4947349 & 0 & "Pb" & 94.5 & "Zn" & 0 & "Au" & 0.3 & "Ag" \\
\hline 1105876.6065532 & 1141162.8117495 & 0 & "Pb" & 73.3 & "Zn" & "nd" & "Au" & nd & "Ag" \\
\hline 1105854.6609093 & 1141109.1631258 & 0 & "Pb" & 94.3 & "Zn" & 0.02 & "Au" & nd & "Ag" \\
\hline 1106044.8564897 & 1141401.7919823 & 0 & "Pb" & 54.4 & "Zn" & 0 & "Au" & nd & "Ag" \\
\hline 1106283.8201676 & 1141689.5436911 & 0 & "Pb" & 134.3 & "Zn" & 0 & "Au" & nd & "Ag" \\
\hline 1106552.0447041 & 1141911.4539073 & 0 & "Pb" & 92.1 & "Zn" & 0.38 & "Au" & nd & "Ag" \\
\hline 1106437.4396749 & 1141021.3744689 & 0 & "Pb" & 93.2 & "Zn" & 0.76 & "Au" & 4.8 & "Ag" \\
\hline 1106617.8816358 & 1141150.6188805 & 0 & "Pb" & 72.6 & "Zn" & 0 & "Au" & nd & "Ag" \\
\hline 1106637.3888748 & 1141135.9874377 & 0 & "Pb" & 127.5 & "Zn" & 0 & "Au" & nd & "Ag" \\
\hline 1106883.6677673 & 1141791.9637909 & 0 & "Pb" & 162.1 & "Zn" & 0.03 & "Au" & nd & "Ag" \\
\hline 1107078.7401575 & 1141738.3151672 & 0 & "Pb" & 149.7 & "Zn" & 0.12 & "Au" & nd & "Ag" \\
\hline 1107142.1386843 & 1141757.8237576 & 19.4 & "Pb" & 152.3 & "Zn" & 0.05 & "Au" & 0.22 & "Ag" \\
\hline 1107147.015494 & 1141416.4234251 & 0 & "Pb" & 121.2 & "Zn" & 0.08 & "Au" & nd & "Ag" \\
\hline 1107129.9466599 & 1141377.4062442 & 0 & "Pb" & 272.1 & "Zn" & 0 & "Au" & 0.9 & "Ag" \\
\hline
\end{tabular}




\begin{tabular}{|c|c|c|c|c|c|c|c|c|c|}
\hline 1107151.8923038 & 1141294.4947349 & 0 & "Pb" & 170.6 & "Zn" & 0 & "Au" & 0.2 & "Ag" \\
\hline 1107164.0843282 & 1141221.3375208 & 0 & "Pb" & 130 & "Zn" & 0 & "Au" & 0.3 & "Ag" \\
\hline 1107232.3596647 & 1141189.6360613 & 0 & "Pb" & 233.4 & "Zn" & 0 & "Au" & nd & "Ag" \\
\hline 1108105.3086106 & 1141535.9135415 & 16.2 & "Pb" & 90.3 & "Zn" & 0 & "Au" & 0.4 & "Ag" \\
\hline 1108110.1854204 & 1141555.4221319 & 13.8 & "Pb" & 81.6 & "Zn" & 0 & "Au" & 0.2 & "Ag" \\
\hline 1106420.3708407 & 1140950.6558286 & 0 & "Pb" & 52.7 & "Zn" & 0.18 & "Au" & 0.2 & "Ag" \\
\hline 1106500.8382017 & 1140970.164419 & 0 & "Pb" & 108.6 & "Zn" & 0.07 & "Au" & 0.7 & "Ag" \\
\hline 1106608.1280163 & 1140779.9556623 & 0 & "Pb" & 74.5 & "Zn" & 0.03 & "Au" & nd & "Ag" \\
\hline 1106598.3743967 & 1140753.1313505 & 0 & "Pb" & 44.4 & "Zn" & 0.16 & "Au" & nd & "Ag" \\
\hline 1106415.494031 & 1140667.7812673 & 0 & "Pb" & 80.2 & "Zn" & 0 & "Au" & 0.8 & "Ag" \\
\hline 1106444.7548895 & 1140638.5183817 & 0 & "Pb" & 1778 & "Zn" & 0.06 & "Au" & 4.3 & "Ag" \\
\hline 1106466.7005334 & 1140326.3809348 & 8 & "Pb" & 80 & "Zn" & 0 & "Au" & 0.14 & "Ag" \\
\hline 1106447.1932944 & 1140294.6794753 & 14 & "Pb" & 96 & "Zn" & 0 & "Au" & 1 & "Ag" \\
\hline 1106293.5737871 & 1140094.7164234 & 12 & "pb" & 84 & "Zn" & 0 & "Au" & 1 & "Ag" \\
\hline 1107200.6604013 & 1140789.7099575 & 0 & "Pb" & 106.2 & "Zn" & 0.45 & "Au" & nd & "Ag" \\
\hline 1107181.1531623 & 1140738.4999076 & 0 & "Pb" & 85.5 & "Zn" & 0 & "Au" & nd & "Ag" \\
\hline 1107373.7871476 & 1140501.9582487 & 11 & "Pb" & 74 & "Zn" & 0 & "Au" & 1 & "Ag" \\
\hline 1107444.500889 & 1140087.400702 & 10 & "Pb" & 132 & "Zn" & 0 & "Au" & 1 & "Ag" \\
\hline 1107483.515367 & 1140048.3835212 & 14 & "Pb" & 88 & "Zn" & 0 & "Au" & 1 & "Ag" \\
\hline 1108010.2108204 & 1140289.8023277 & 12 & "Pb" & 66 & "Zn" & 0 & "Au" & 1 & "Ag" \\
\hline 1108410.1092202 & 1140701.9213006 & 12.8 & "Pb" & 77.8 & "Zn" & 0 & "Au" & 0.2 & "Ag" \\
\hline 1108436.9316739 & 1140726.3070386 & 14.5 & "Pb" & 68.8 & "Zn" & 0 & "Au" & 0.2 & "Ag" \\
\hline 1105327.9654559 & 1140736.0613338 & 7.3 & "Pb" & 62.1 & "Zn" & 0.08 & "Au" & 0.15 & "Ag" \\
\hline 1105379.1719583 & 1140714.1141696 & 13.3 & "Pb" & 102.6 & "Zn" & 0.06 & "Au" & 0.62 & "Ag" \\
\hline 1105332.8422657 & 1140516.5896915 & 8.6 & "Pb" & 54 & "Zn" & 0 & "Au" & nd & "Ag" \\
\hline 1105379.1719583 & 1140477.5725106 & 15.4 & "Pb" & 104.5 & "Zn" & 0 & "Au" & 0.96 & "Ag" \\
\hline 1104598.8823978 & 1140289.8023277 & 17.5 & "Pb" & 125.8 & "Zn" & 1.606 & "Au" & 0.64 & "Ag" \\
\hline 1102806.6548133 & 1140187.382228 & 8.3 & "Pb" & 69.1 & "Zn" & 0 & "Au" & 0.2 & "Ag" \\
\hline 1102738.3794768 & 1140350.7666728 & 10 & "Pb" & 72.7 & "Zn" & 0 & "Au" & 0.2 & "Ag" \\
\hline 1102411.6332233 & 1140653.1498245 & 11 & "Pb" & 83.5 & "Zn" & 0 & "Au" & 0.2 & "Ag" \\
\hline 1102418.9484379 & 1140875.0600406 & 10.6 & "Pb" & 82.3 & "Zn" & 0 & "Au" & 0.2 & "Ag" \\
\hline 1102365.3035306 & 1140875.0600406 & 10.7 & "Pb" & 84.6 & "Zn" & 0 & "Au" & 0.2 & "Ag" \\
\hline 1102394.5643891 & 1140102.0321448 & 8.3 & "Pb" & 72.5 & "Zn" & 0 & "Au" & 0.2 & "Ag" \\
\hline 1102123.9014478 & 1139636.2645483 & 10.7 & "Pb" & 94 & "Zn" & 0 & "Au" & 0.2 & "Ag" \\
\hline 1104657.4041148 & 1139909.3848143 & 11.1 & "Pb" & 66.5 & "Zn" & 0.05 & "Au" & 0.19 & "Ag" \\
\hline
\end{tabular}




\begin{tabular}{|c|c|c|c|c|c|c|c|c|c|}
\hline 1105306.019812 & 1139631.3874007 & 18.3 & "Pb" & 86.3 & "Zn" & 0.295 & "Au" & 0.46 & "Ag" \\
\hline 1105498.6537973 & 1139789.8946979 & 27.5 & "Pb" & 86 & "Zn" & 0.137 & "Au" & 0.18 & "Ag" \\
\hline 1105564.490729 & 1139833.7890264 & 17.9 & "Pb" & 127 & "Zn" & 0.212 & "Au" & 0.27 & "Ag" \\
\hline 1107173.8379477 & 1139011.9896545 & 18.6 & "Pb" & 15.2 & "Zn" & 0 & "Au" & 0.3 & "Ag" \\
\hline 1107188.4683769 & 1139055.883983 & 14.3 & "Pb" & 10.4 & "Zn" & 0 & "Au" & 0.2 & "Ag" \\
\hline 1107456.6929134 & 1139111.9711805 & 132.7 & "Pb" & 65.5 & "Zn" & 0 & "Au" & 0.2 & "Ag" \\
\hline 1107444.500889 & 1139051.0068354 & 15.3 & "Pb" & 80.9 & "Zn" & 0 & "Au" & 0.2 & "Ag" \\
\hline 1103755.1943104 & 1138746.1851099 & 11.6 & "Pb" & 78.5 & "Zn" & 0 & "Au" & nd & "Ag" \\
\hline 1104050.2413005 & 1138258.4703492 & 10.8 & "Pb" & 108.4 & "Zn" & 0 & "Au" & 0.3 & "Ag" \\
\hline 1104094.1325883 & 1138287.7332348 & 11.8 & "Pb" & 85.7 & "Zn" & 0 & "Au" & 0.3 & " Ag" \\
\hline
\end{tabular}


Anexo 3. Sensibilidade.

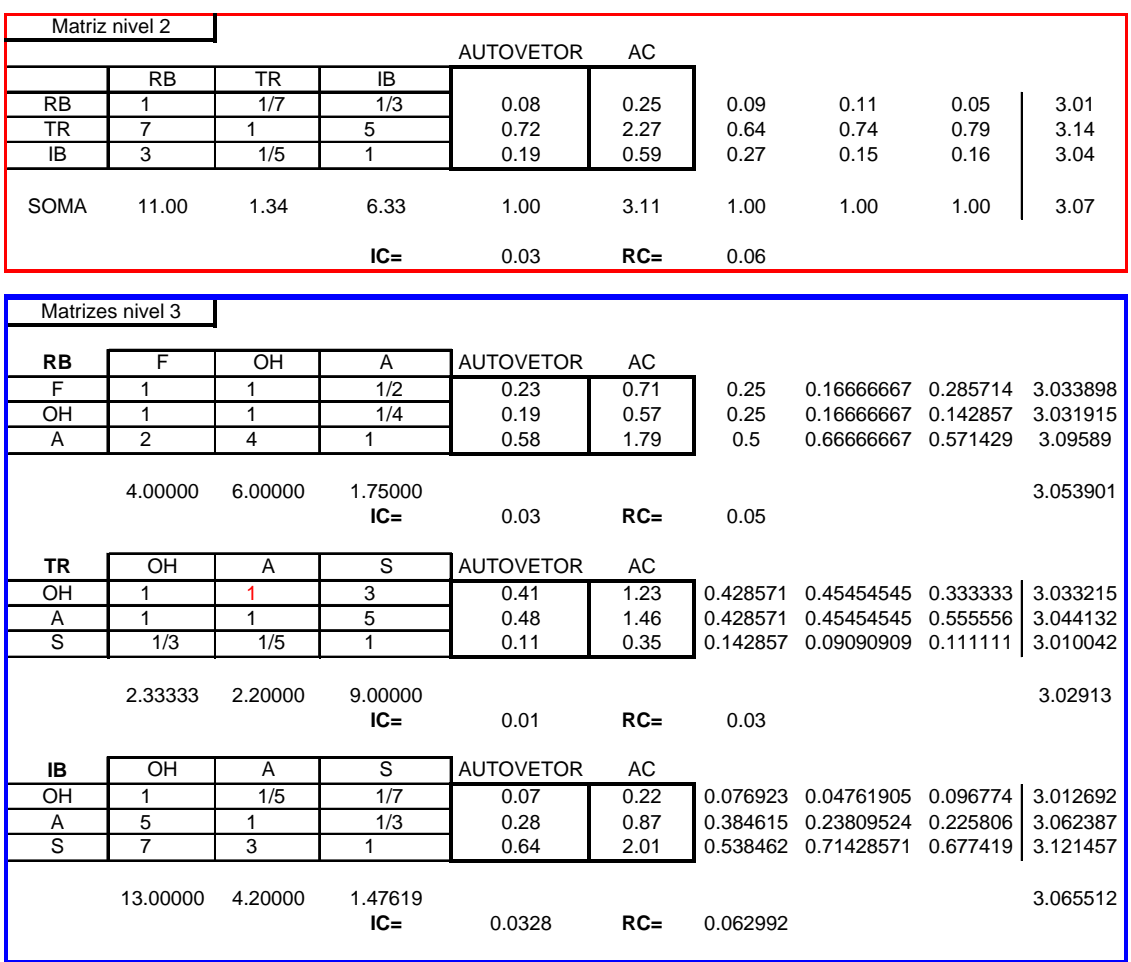

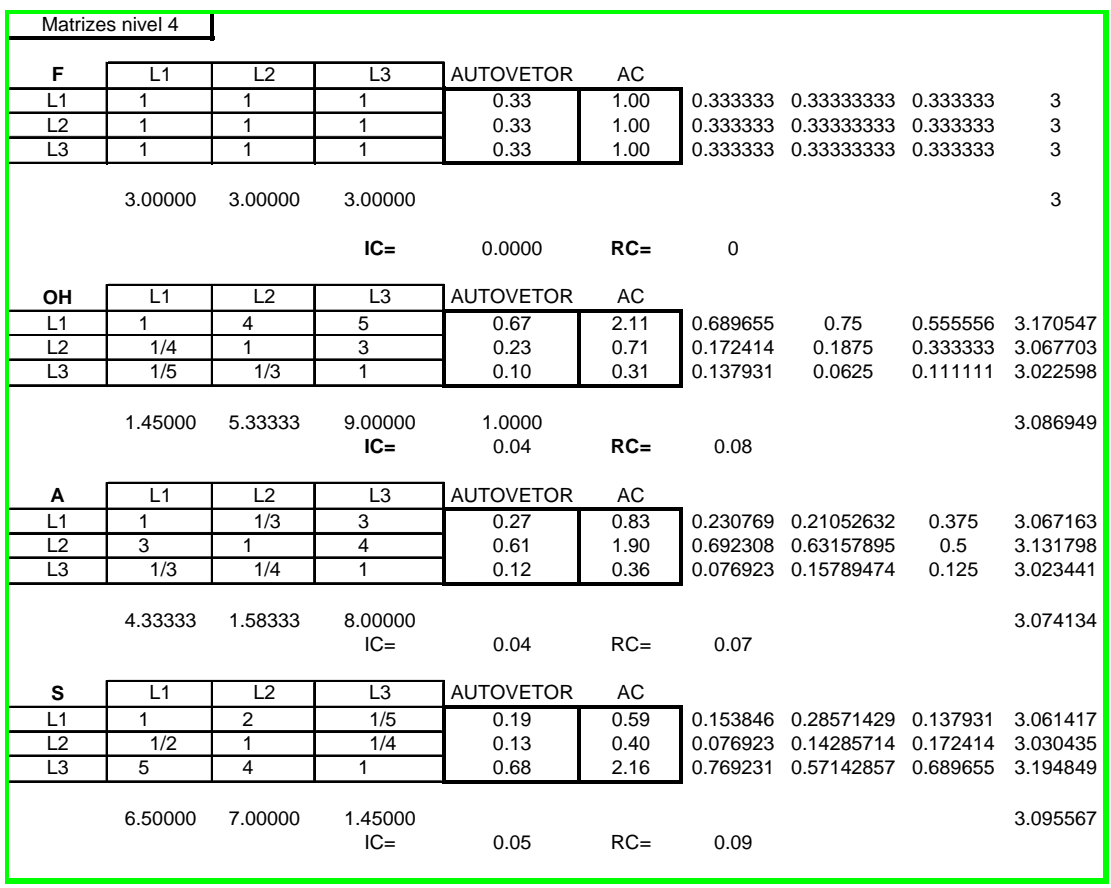

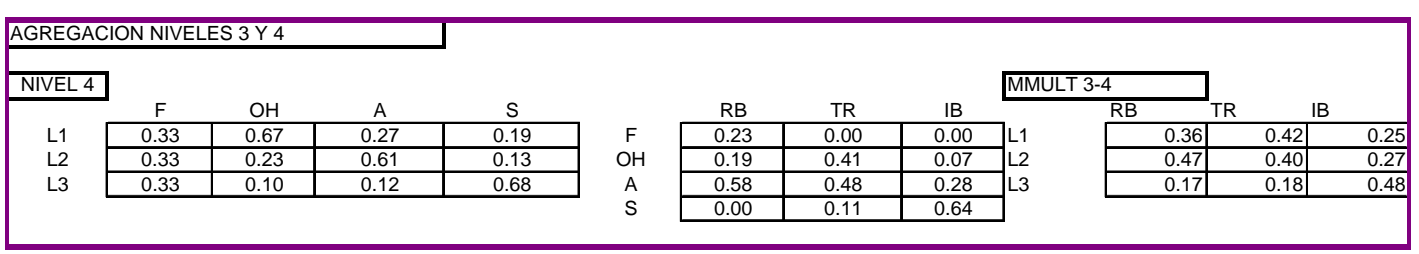

\begin{tabular}{|c|c|c|c|c|c|c|c|}
\hline \begin{tabular}{|l|} 
NIVEL 3-4 \\
\end{tabular} & & & & NIVEL 2 & & & PESOS FINALES \\
\hline & $\mathrm{RB}$ & TR & IB & \multirow{5}{*}{$\begin{array}{l}\text { RB } \\
\text { TR } \\
\text { IB }\end{array}$} & & \multirow{4}{*}{$\begin{array}{l}\mathrm{L} 1 \\
\mathrm{~L} 2 \\
\mathrm{~L} 3\end{array}$} & \\
\hline L1 & 0.36 & 0.42 & 0.25 & & 0.08 & & 0.38 \\
\hline L2 & 0.47 & 0.40 & 0.27 & & 0.72 & & 0.38 \\
\hline \multirow[t]{2}{*}{ L3 } & 0.17 & 0.18 & 0.48 & & 0.19 & & 0.23 \\
\hline & 1.00 & 1.00 & 1.00 & & 1.00 & & 1.00 \\
\hline
\end{tabular}

VARIANTE MULTIPLICATIVA

\begin{tabular}{ll}
\hline L1/L2 & 1.00 \\
L2/L3 & 1.76 \\
L1/L3 & 1.76
\end{tabular}

